PROTEST AND SOCIAL MOVEMENTS

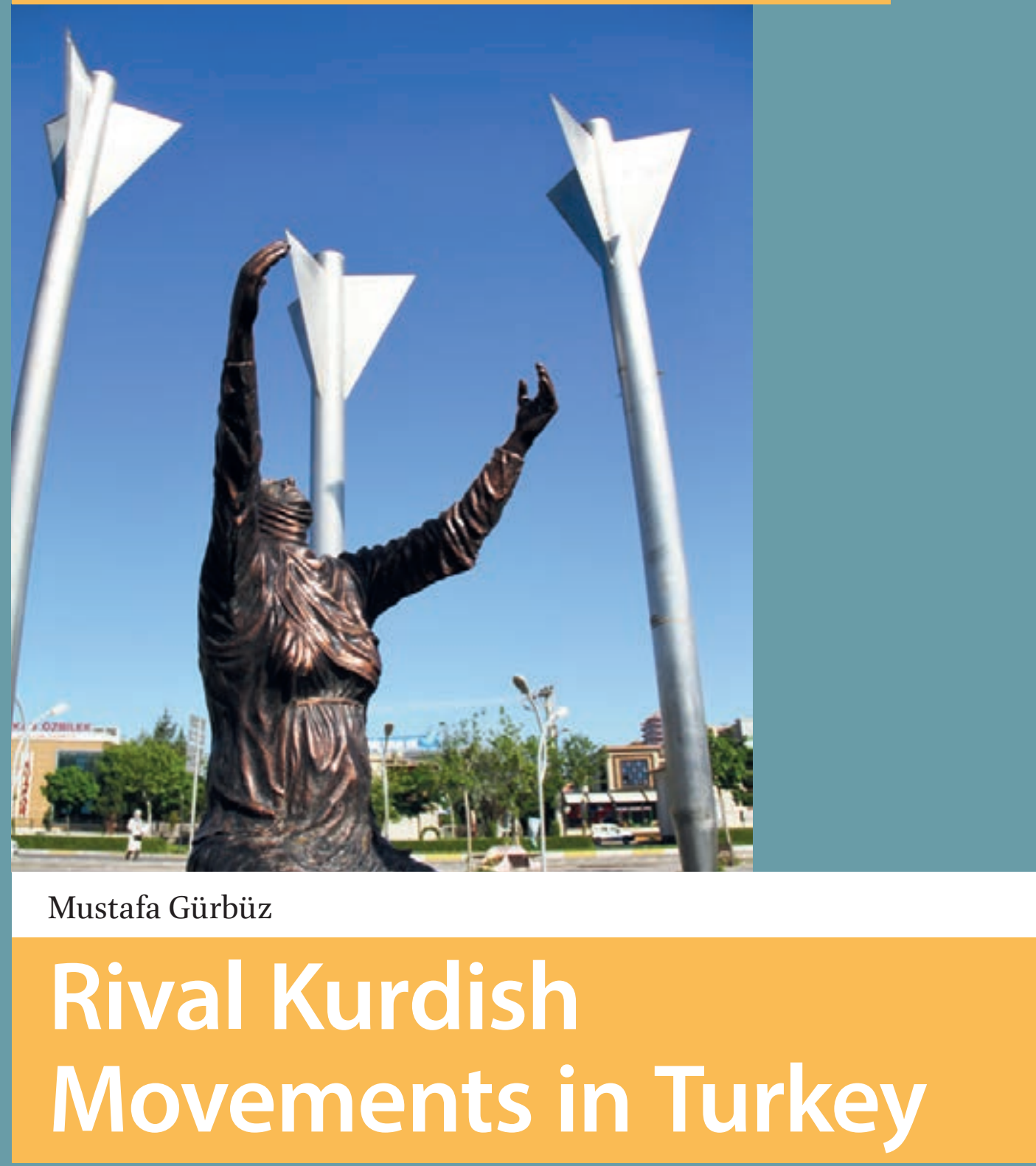

\title{
Transforming Ethnic Conflict
}


Rival Kurdish Movements in Turkey 


\section{Protest and Social Movements}

Recent years have seen an explosion of protest movements around the world, and academic theories are racing to catch up with them. This series aims to further our understanding of the origins, dealings, decisions, and outcomes of social movements by fostering dialogue among many traditions of thought, across European nations and across continents. All theoretical perspectives are welcome. Books in the series typically combine theory with empirical research, dealing with various types of mobilization, from neighborhood groups to revolutions. We especially welcome work that synthesizes or compares different approaches to social movements, such as cultural and structural traditions, micro- and macro-social, economic and ideal, or qualitative and quantitative. Books in the series will be published in English. One goal is to encourage nonnative speakers to introduce their work to Anglophone audiences. Another is to maximize accessibility: all books will be available in open access within a year after printed publication.

Series Editors

Jan Willem Duyvendak is professor of Sociology at the University of Amsterdam. James M. Jasper teaches at the Graduate Center of the City University of New York. 


\section{Rival Kurdish Movements in Turkey}

Transforming Ethnic Conflict

Mustafa Gürbüz 
Cover illustration: Roboski Monument in Diyarbakır, photo by Ismail Avci

(c) Ismail Avci

Cover design: Coördesign, Leiden

Typesetting: Crius Group, Hulshout

Amsterdam University Press English-language titles are distributed in the US and Canada by the University of Chicago Press.

$\begin{array}{ll}\text { ISBN } & 978 \text { 90 } 89648785 \\ \text { e-ISBN } & 97890485^{2} 7427 \text { (pdf) } \\ \text { DOI } & 10.5117 / 9789089648785 \\ \text { NUR } & 697 \mid 763\end{array}$

(C) Mustafa Gürbüz / Amsterdam University Press B.V., Amsterdam 2016

All rights reserved. Without limiting the rights under copyright reserved above, no part of this book may be reproduced, stored in or introduced into a retrieval system, or transmitted, in any form or by any means (electronic, mechanical, photocopying, recording or otherwise) without the written permission of both the copyright owner and the author of the book.

Every effort has been made to obtain permission to use all copyrighted illustrations reproduced in this book. Nonetheless, whosoever believes to have rights to this material is advised to contact the publisher. 


\section{Table of Contents}

$\begin{array}{ll}\text { Acknowledgments } & 7\end{array}$

$\begin{array}{ll}\text { Introduction } & 9\end{array}$

1 Ethnic Conflict and Social Movements 11

A Multi-Institutional Politics Approach

$\begin{array}{ll}\text { What Makes a Kurdish Activist } & 16\end{array}$

The Argument of the Book 23

How Does Meaning-Making Matter? $\quad 25$

$\begin{array}{ll}\text { Organization of the Book } & 29\end{array}$

2 Kurdish Movements in the Southeast 31

The Kurdish Ethno-Nationalist Movement 33

Hizbullah in Turkey $\quad 36$

The Gülen/Hizmet Movement $\quad 39$

Locating the Pro-Islamic AKP 43

3 Exogenous Shocks on the Eve of the Millennium 49

Abdullah Öcalan: The Role of the PKK Leader in Shaping

Kurdish Politics $\quad 50$

The EU Factor: Turkey's Membership Process and De-
Securitization

Securitization $\quad 55$

Changing International Political Environment $\quad 5^{8}$

The Rise of the AKP: Radical Shifts in Turkish Politics 60

4 Civic Competition and Conflict Transformation 65

Emerging Arenas of Competition in the Kurdish Civic Sphere $\quad 69$

$\begin{array}{ll}\text { Arenas of Competition and Strategy-Making } & 71\end{array}$

5 Resemblance and Difference $\quad 77$

Constructing Kurdish Civil Society
Why Charity Organizations?

Exogenous Shocks: Increasing Poverty and the Emergence of

$\begin{array}{ll}\text { Kurdish Slums } & 81\end{array}$

Constructing Competition through Resemblance: The Charity Initiatives $\quad 84$

"Education is Our Job": The Gülen Movement Goes to Slums 89 
Namûsa Me Azadîya Me Ye: The Democratic Free Women's

Movement

Religious Public Symbolism: Hizbullah Finds Its Niche 101

Civic Activism and Conflict Transformation 105

6 Going Native

109

Contesting Kurdish Islam

Revolutionary Ideology as a Discursive Process

110

The Kurdish Ethno-Nationalist Movement, Islamic Identity, and Symbolic Localization

Symbolic Localization and Conflict Transformation

7 Îslam Çareser e

Islamic Activists Discover Kurdish

Increasing Competition over Kurdish Language

Hizbullah: From Ayatollah Khomeini to Said Nursi

139

HÜDA-PAR: Calling the Party of God in Kurdish

8 Enemies of the "Deep State"

Narrative Contests and Symbolic Localization

The "Deep State" and Kurds

The Rival Movements and Competing Narratives on Ergenekon

149

The Gülen/Hizmet as Enemy of the Deep State

The PKK: "The State wants to sweep its filth under the carpet!"

155

Hizbullah: "We're the Victims of the Deep State!"

158

Narratives in Conflict Transformation: Reputation Work and

Symbolic Localization

9 Conclusion

Strategic Engagement and Conflict Transformation $\quad 166$

Global Dynamics and Pro-Ethnic Strategies $\quad 168$

Toward a Multi-Institutional Politics Perspective $\quad 170$

A Kurdish Spring on the Horizon? 174

$\begin{array}{lr}\text { List of Abbreviations } & 177\end{array}$

$\begin{array}{lr}\text { References } & 179\end{array}$

Appendix: Data and Methods 199

Index 


\section{Acknowledgments}

"It takes a village," as the saying goes. Begun as a doctoral dissertation

project at the University of Connecticut, this book's journey took a village to be completed. I accumulated so many debts to so many individuals who generously gave their time and knowledge. Among them, two names deserve specific mention: Mary Bernstein and Charles Kurzman. Mary was an exceptional mentor, carefully and patiently reading numerous drafts. Similarly, Charlie supervised the project from its inception and provided invaluable guidance in transforming a dull dissertation into a work of art. I am also much indebted to Nancy Naples and Bandana Purkayastha for their feedback and support at the initial phase of the project.

I am most grateful for comments and criticism of those who read either the entire manuscript or earlier versions of individual chapters including Robert Benford, Marlies Casier, James DeFronzo, Nicole Doerr, Vera Eccarius-Kelly, Gülsüm Gürbüz-Küçüksarı, Randle Hart, James Jasper, Joost Jongerden, Turan Kayaoğlu, Ahmet Kuru, David Romano, Renat Shaykhutdinov, Lee Smithey, Marc Steinberg, Güneş Tezcür, Stephen Turner, and Ahmet Yükleyen. Special thanks to the organizers and attendees of the First Young Scholars in Social Movements conference in the Center for the Study of Social Movements at the University of Notre Dame - particularly to Ron Aminzade, Doug McAdam, John McCarthy, and Rory McVeigh - for their constructive feedback.

My post-doctoral appointments at the University of South Florida and George Mason University enabled me to crystallize the arguments raised in this book. I thank Sinem Adar, Gavin Benke, Peter Funke, David Jacobson, Zacharias Pieri, and Roger Stanev for their intellectual companionship at the University of South Florida. I also thank Şeyma Akyol and Melikşah Ayvaz for research assistance at the final stage of manuscript preparation. All of my editors at Amsterdam University Press, especially Saskia Gieling, Vanessa de Bueger, Jaap Wagenaar, and Carrie Ballard, were most helpful.

An earlier version of chapter 6 was published in Sociological Inquiry ("Ideology in Action: Symbolic Localization of Kurdistan Workers' Party," vol. 85, no: 1, 2015). Portions of some chapters appeared in "Sold Out to the Enemy': Emerging Symbolic Boundaries in Kurdish Politics and Strategic Uses of Labeling Treason," European Journal of Turkish Studies vol. 14 (2012) as well as "Revitalization of Kurdish Islamic Sphere and Revival of Hizbullah in Turkey" in Fevzi Bilgin and Ali Sarihan (eds.) Understanding Turkey's Kurdish Question Lanham, MD: Lexington Books, 2013. 
I dedicate this book to my wife, Tuğba, who not only traveled with me to the field in the initial phase of this research but also supported me at every step along the way. Over the years, we have shared the pain and joy of scholarship and intellectual life. I am truly grateful to her. 


\section{Introduction}

We used to think that people who were not with us were truly the enemies of Islam. Even if they were Muslims. We soon became afraid of even our own wives. It's because we were living in a system where everybody was a suspect. Yet, thank God, compared to the past, we can gather more people (around us) and help them nowadays. If you ask me what has changed in me, I would tell that I have come to realize that words are more powerful than weapons and I never take up a gun anymore ... In the past, we used to take action against our enemies with guns; but now and then, we respond to them with ideas, books, conferences, and meetings.

These are the words of a Kurdish Hizbullah member speaking to a journalist about Hizbullah's transformation in the past decade. ${ }^{1}$ As the activist clearly points out, the master strategy of Hizbullah has changed. Armed revolutionaries, formerly lodged underground, would now seek a place within the civic sphere on democratic grounds. In 2004, the very year Hizbullah released its first publication ever, interesting civic initiatives were taking place among militant leftist Kurds as well. A guerilla commander explained why the Kurdistan Workers' Party (PKK) undertook such a radical transformation:

After thirty years of struggle and changes in the world, we also changed. As a result of the Kurdish freedom struggle we had to leave behind the struggle based on one class and nation. We have accepted Öcalan's defense writings for the (European) Human Rights Court as a manifesto for us. The manifesto calls for democratic civilization and an understanding of the history of human beings. We have a new organization, the Democratic Ecological Society. When we don't clash directly with the state but disagree with them, this leads to a more democratic approach. By doing this, the basic aim is to develop a democratic mentality in the society. In the Middle East, there is a reality of religious/nationalist clashes. In this perspective, members of Kongra-Gel [the new platform of the PKK movement] try to solve their problems within the Democratic Ecological Society in a democratic manner. ${ }^{2}$

1 Çiçek 2008: 58-59.

2 Interview with David Romano in the PKK camp in Iraq's Qandil Mountains, see Romano 2006: 145 . 
Hizbullah and PKK militants both attest to the fact that Kurdish politics in Turkey have undergone a great transformation over the past decade. On the eve of the new millennium, the Turkish State was still openly denying the existence of Kurds, calling them "mountain Turks," and Kurdish-populated cities were ruled under martial law. Kurdish politics in Turkey was largely dominated by violent PKK guerillas in the Qandil Mountains. Less than a decade later, the PKK's total war with the Turkish State had all but ended, and Kurdish political movements of numerous stripes had emerged. The Turkish State even introduced an official Kurdish language TV channel. How did this rapid change occur?

Imagine that Herbert G. Wells' time machine exists and you are transported to 1990 s Diyarbakır, the key city for Kurdish political activism. Before your trip, people repeatedly advise that you be careful and stay inside at night. After your arrival, you hear stories of death, kidnapping, interrogation, and torture every day. Some Kurds blame Hizbullah for this violence while others charge the PKK. Most Kurds do not report the events to the police, fearing that the perpetrators might actually be the Turkish Armed Forces' unofficial intelligence unit, JITEM. Living at this moment, you would quickly notice that the PKK and Hizbullah militants are engaged in a bloody fight against each other. The death toll reaches tens of thousands, comparable to the notorious dirty wars in modern Spain and Argentina.

However, this is not the look of the Diyarbakır of 2016. The anarchic atmosphere of the 199os is long gone. The PKK's larger platform, the Kurdistan National Congress (KCK), encourages its dedicated followers to join pro-Kurdish political activism. Hizbullah members open new civic centers each year, control numerous media outlets, and run for office in the name of their new political party, the Party of God (HÜDA-PAR). The pro-Islamic Gülen movement's Kurdish activists have no fear of establishing educational centers in slums where PKK recruitment is high.

Why do radicals change? How do militant pro-ethnic actors such as PKK and Hizbullah members become moderate social movement activists? I argue that pro-ethnic activists may find their interests are best served by constructing a non-violent competition culture for the sake of gaining material as well as symbolic resources such as legitimacy, reputation, and prestige. This book explores the conditions that encourage this non-violent engagement and explains the mechanisms of social movement competition in emerging civil societies. It is a study of conflict transformation in ethnic politics. 


\title{
1 Ethnic Conflict and Social Movements
}

\author{
A Multi-Institutional Politics Approach
}

"In the next decades," wrote Robert Rubinstein in the afterword of a recent volume on conflict resolution,

[I]t will become increasingly important for peace and conflict scholars to understand the dynamics of actors 'below the level of the nation state'; that is, of citizens acting as individuals and in groups to effect change. Increasingly, citizens at a variety of levels of organization, from small voluntary associations through larger, more formally organized groupings, like nongovernmental organizations and activist organizations, are involved in defining the scope and nature of conflicts in the contemporary world. As a result, it is especially important that peace and conflict scholars develop frameworks for understanding how local groups project political authority, and how they gain standing among large groups of people and articulate these understandings through the political process. ${ }^{1}$

Rubinstein's call for attention to grassroots activism is especially important for ethnic conflict studies, which increasingly address the questions of identity and belonging. As globalization provides an impetus for the revival of local identities, ${ }^{2}$ we begin to witness a resurgence of identity based ethnic clashes which are the most difficult conflicts to transform positively. ${ }^{3}$

Pro-ethnic grassroots activism and social transformation, however, is understudied by scholars. Dominant paradigms of ethnic conflict prioritize either structural forces, such as the nation state building, ${ }^{4}$ or socio-psychological dynamics, such as boundary-making and out-group demonization. ${ }^{5}$

\footnotetext{
1 Rubinstein 2008: 283-84.

2 The literature on resurgence of local identities under globalization grows fast. For prominent works from European and American scholarship respectively, see Castells 1997 and Olzak 1992, 2006. For a comprehensive review, see Bernstein 2005.

3 For more on challenges of ethnic divisions in conflict transformation, see Ross 2007, 2009; Smithey 2011.

4 See Gellner 1983 and Aktürk 2012.

5 For the boundary-making approach, see Sahlins 1989, Brubaker 1992, Wimmer 2008, 2013. For more on socio-psychological approaches, see Volkan 1998, 2006; Boudreau and Polkinghorn 2008.
} 
Despite their useful insights, these two perspectives suffer from significant deficiencies in attempting to explain transformations in ethnic conflicts. Explaining changes in ethnic politics by the pure factuality of state policies, the former falls into the trap of what Alberto Melucci calls "action without an actor." ${ }^{n}$ Likewise, the latter depicts an "actor without action"7 by overstating the role of emotions in conflict transformation. Thus, there is an ever-growing need to link these two distinct paradigms in analysis.

Doug McAdam, Sidney Tarrow, and Charles Tilly aptly criticize the surprising disconnection between ethnic conflict literature and social movement scholarship. The detachment is due to an increasing "scholarly specialization" that "has left many ethnic conflict scholars largely uninformed of recent advances in social movement theory," whereas on the other hand, "social movement theorists from the West have generally chosen more bounded, less volatile movements to study than those based on ethnicity and religion." ${ }^{8}$

In this book, I utilize a multi-institutional politics approach to study ethnic conflict transformation (see Table 1.1). ${ }^{9}$ A multi-institutional politics approach rejects the notion that power is solely vested in the nation state; instead, it regards power as dispersed across social institutions including religion, economy, civic initiatives, and cultural norms. ${ }^{10}$ Unlike structuralist accounts of social movements, ${ }^{11}$ this account analyzes ethnic mobilizations in their own local dynamics and historical contingencies. In this view of society, the nation state is certainly an important actor in ethnic politics because it has remarkable resources to shape other social institutions; however, the role of the nation state should be understood within the larger multi-institutional environment. Pro-ethnic activists challenge not only the nation state but also cultural norms, legal institutions, science, religious authority, fiction, and institutions of education. Moreover, their activism targets not only institutions but also activists from other pro-ethnic movements who compete for the same constituents, resources, and goals. ${ }^{12}$

6 Melucci 1988: 329 .

7 Ibid.

8 McAdam, Tarrow, and Tilly 1996: 21.

9 For the Multi-Institutional Politics perspective, see Armstrong and Bernstein 2008, Gürbüz and Bernstein 2012, Steinman 2012, Bernstein 2013.

10 Armstrong and Bernstein 2008: 82.

11 For path-breaking works in this tradition, see Tilly 1978 and McAdam 1982.

12 An exclusive focus on the relations between the PKK and the Turkish state, for example, would depict a single insurgent ethnic movement under the forces of a semi-authoritarian regime. In this "incumbent vs. challenger" perspective, state repression appears to be an explanatory cause for the PKK insurgency, and thus, we can expect that more democratic 
As seen in Table 1.1, one of the key research questions in the multiinstitutional politics perspective asks why challenges take the forms that they do. The structuralist paradigm explains "movement form" by political opportunity structures. ${ }^{13}$ Robert White, for example, argues that it was primarily state repression that led the Irish Republican Army to employ violent methods. ${ }^{14}$ Vincent Boudreau maintains that political opportunity structures directed many democratic movements toward a militant course, especially in authoritarian settings. ${ }^{15}$ In his analysis of protest waves in El Salvador, Paul Almeida suggests that state sponsored repression causes violent forms of resistance. ${ }^{16}$

A multi-institutional politics approach remains cautious about the aforementioned structuralist explanations of movement forms. In crafting their political strategy, pro-ethnic activists found themselves in a "multiorganizational field" with multiple targets. ${ }^{17}$ State policies, therefore, should be considered in the specific local context when it comes to analyzing movement forms. Ali Mazrui, for example, finds that the cross-cutting nature of ethnic and religious divisions might reduce ethnic violence in certain contexts. ${ }^{18}$ In this regard, Jeff Goodwin's study of categorical terrorism is noteworthy. Goodwin indicates that socio-cultural elements such as religion, language, and territory are remarkably significant in shaping the type of violence that insurgents use. Categorical terrorism, he argues, is "most likely where there has been little such interaction or cooperation, resulting in weak political alliances between the revolutionaries and complicitous civilians," for instance "where the revolutionaries and complicitous civilians speak different languages, practice different religions, claim the

reforms would lead to moderation, especially after the PKK's total defeat in 1999. And yet why did the PKK decide to retake up arms right after the implementation of pro-Kurdish reforms in 2004? As Güneş Tezcür (2010b) points out, the pro-Islamic AKP emerged as a competitor for Kurdish votes, and thus, organizational competition led to the PKK's rearmament. Similarly, why did the pro-Kurdish party, frequently victimized by official closures of political parties, reject constitutional reform that would minimize political party closures in Turkey? Again, this apparent contradiction could only be explained by examining the role of pro-Islamic actors such as the AKP and the Gülen movement in Kurdish politics. Political opportunities, thus, should be examined within the larger multi-institutional environment where local actors and cultural dynamics play a key role. For a conceptual discussion based on various local contexts, see Goodwin and Jasper 2011.

13 McAdam 1996: 29 .

14 White 1989: 1277 .

15 Boudreau 1996: 185.

16 Almeida 2008.

17 Curtis and Zurcher 1973: 53 .

18 Mazrui 2000: 37. 
same land, and/or are territorially segregated."19 Goodwin's broader account of socio-cultural elements, which are tied to a variety of social institutions, goes beyond the traditional literature on state repression and provides a better understanding of insurgent movement forms.

A multi-institutional politics perspective offers insight not only into structuralist social movement theories but also into structuralist approaches within ethnic conflict literature. The cross-cutting power of religion over ethnicity or vice versa, for example, is often disregarded or omitted in ethnic conflict studies. ${ }^{20}$ Research questions are often shaped along structuralist lines such as "does Islam solve the Kurdish question?" and "did Catholicism support the Basque separatism in Spain?" ${ }^{21}$ A multi-institutional approach to ethno-politics, instead, would locate religious institutions in a larger field of ethnic political contestation and thus provides better insights about transformations in ethnic conflicts.

Along these lines, Philip Gorski and Gülay Türkmen-Dervişoğlu rightly argue that one should investigate "whether ethnicity trumps class or vice versa, which ethnic categories are central and which are peripheral, are not fixed or given but continually up for grabs"; therefore, we need to understand that "ethnicity and nationalism are not structures but processes, not entities but relations, not things but events." ${ }^{22}$

The complex relationship between religion and ethno-politics, thus, moves scholars to go beyond the sphere of formal governance. Unlike the structuralist perspective that defines ethno-politics within the boundaries of the formal political arena, the multi-institutional politics perspective locates ethno-politics within the broader power struggles in the society as it manifests in the state, other key institutions, and culture (see Table 1.1). This broader definition of ethno-politics challenges the traditional definition of "pro-ethnic" movements in the mainstream literature.

Structuralist accounts would locate pro-ethnic movements vis-a-vis the state, defining their identity against the established order. Thus, by definition, ethnic movements "incite conflict against other ethnic groups, make claims to authorities demanding the end of discrimination, or make demands for expanded rights of geographical autonomy, separatism, or statehood that are not being met." ${ }^{23}$ This view, however, does not consider

20 For a comprehensive criticism of this omission in the current literature, see Gorski and Türkmen-Dervişoğlu 2013.

21 For the Kurdish case, see Çiçek 2008 and Sarigil 2010. For the Spanish case, see Molina 2011. 
Table 1.1 Comparing structuralist and multi-institutional politics perspectives

\begin{tabular}{|c|c|c|}
\hline & Structuralist & Multi-Institutional Politics \\
\hline \multirow[t]{2}{*}{$\begin{array}{l}\text { Model of society } \\
\text { and power }\end{array}$} & $\begin{array}{l}\text { a. Domination organized } \\
\text { around the state }\end{array}$ & $\begin{array}{l}\text { a. Domination organized } \\
\text { around the state, other } \\
\text { institutions, and culture }\end{array}$ \\
\hline & b. Culture as secondary & b. Culture as constitutive \\
\hline \multirow[t]{2}{*}{$\begin{array}{l}\text { Goal of pro-ethnic } \\
\text { movements }\end{array}$} & a. State as target & $\begin{array}{l}\text { a. State, other institutions, and/ } \\
\text { or culture as targets }\end{array}$ \\
\hline & $\begin{array}{l}\text { b. Seeks policy change, new } \\
\text { benefits, or inclusion }\end{array}$ & $\begin{array}{l}\text { b. Seeks policy change, new } \\
\text { benefits, inclusion, cultural } \\
\text { change, or changes in the } \\
\text { rules of the game }\end{array}$ \\
\hline $\begin{array}{l}\text { Definition of } \\
\text { ethno-politics }\end{array}$ & $\begin{array}{l}\text { a. Related to governance, } \\
\text { formal political arena }\end{array}$ & $\begin{array}{l}\text { a. Related to power, as it } \\
\text { manifests itself in the state, } \\
\text { other institutions, or culture }\end{array}$ \\
\hline $\begin{array}{l}\text { Key research } \\
\text { questions }\end{array}$ & $\begin{array}{l}\text { a. Under what conditions do } \\
\text { pro-ethnic movements } \\
\text { originate, survive, and } \\
\text { succeed? }\end{array}$ & $\begin{array}{l}\text { a. Why do pro-ethnic } \\
\text { movements take the forms } \\
\text { that they do? What does } \\
\text { the interaction between } \\
\text { challengers and target } \\
\text { tell us about the nature } \\
\text { of domination in society? } \\
\text { Under what conditions do } \\
\text { challenges originate, survive, } \\
\text { and succeed? }\end{array}$ \\
\hline
\end{tabular}

Adapted from Armstrong and Bernstein 2008: 76

hybrid social movements that utilize ethnic repertoires against pro-ethnic players as well as those actors aiming to transform the "rules of the game." ${ }^{24}$ As Susan Olzak notes, "different layers of cultural difference expressed as ethnicity" complicate the issue. ${ }^{25}$ Moreover, consciousness along ethnic lines changes over time, especially with the diffusion of global human rights ideologies. Thus, "the persistence of any gap in human rights, income, well-being, minority treatment, etc., among ethnic groups" is now conceived primarily in terms of ethnic identity issues. ${ }^{26}$

The multi-institutional politics perspective enables researchers to understand ethnic conflicts in a broader context, and therefore it suggests useful insights on conflict transformations. The definition of ethno-politics

24 Armstrong and Bernstein 2008: 76.

25 Olzak 2006:30. For an in-depth discussion on this particular point, see Brubaker and Cooper 2000 .

26 Olzak 2oo6: 12 . 
and ethno-political actors is expanded to include hybrid movements such as religious mobilizations. Consider for example the presence of Hizbullah in Southeast Turkey. Based on an Islamic worldview, Hizbullah's Kurdish activists support both pro-Kurdish rights and Islamic brotherhood in the region. Should this be considered a pro-ethnic movement? Since the movement is not a challenge to the Turkish State, the mainstream structuralist perspective would answer in the negative. In the multi-institutional politics perspective, however, we might consider Hizbullah as a pro-ethnic movement. In a region where ethnic identity and Islamic identity are not easily separable, pro-Islamic and pro-Kurdish identities blur in Hizbullah activism. The same logic applies to the pro-Islamic Gülen movement's Kurdish activists whose identities blend religion and ethnicity in strong ways. The Gülen activists aim to change the rules of the game in Kurdish politics, and they systematically challenge the PKK and Hizbullah. That is why the Gülen activists are primarily perceived as "pro-ethnic" activists: ironically, they are seen as "pro-Turkish" in the eyes of their rivals in the region but portrayed as "pro-Kurdish" among others.

Hence, considering hybrid religious movements as important "pro-ethnic" players, we can define the field of Kurdish politics more broadly, as suggested by the multi-institutional politics perspective. A broader perspective of ethno-politics will enlighten the processes of conflict transformation.

\section{What Makes a Kurdish Activist}

David Romano's book The Kurdish Nationalist Movement remains an essential study in conceptualizing various pro-Kurdish struggles through the lenses of social movement theory. Romano explains how Kurdish activist identities are formed as freedom fighters not only in Turkey but also in the larger Middle East.

Romano's theoretical synthesis pays specific attention to (a) political opportunities, (b) resource mobilization, and (c) cultural framing. Unlike earlier work on Kurdish nationalism that either prioritizes opportunities or resources ${ }^{27}$ Romano regards culture and framing seriously as they are in constant relation with structural factors. The PKK insurgency was not a simple extremist reaction to state oppression but a strong mobilization

27 Most essential works on Kurdish nationalism are Olson 1989, van Bruinessen 1992, McDowall 1997, and Wadie Jwaideh's (2006) seminal doctoral dissertation in 1960 published as a book after four decades. 
effort in mundane life. PKK activists called on ethnic Kurds in Turkey to join the "freedom fight" by narrating that

(1) their problems were not theirs alone, but rather shared by all Kurds; (2) these problems resulted from a system perpetuated by foreign (non-Kurdish) colonizing and exploitative governments; (3) the Kurdish nation should and could mobilize together to challenge the system; and (4) the movement presently organized and bringing them this message was the most available, suitable, credible, and legitimate vehicle for such mobilization. ${ }^{28}$

Romano also explains how numerous technological advances in communication were utilized in the PKK's framing efforts. He rightly captures that the PKK insurgency has become greater than its main components, and thus, the nature of guerilla tactics has changed.

"If Kongra-Gel or other Kurdish challenger groups," argues Romano, "could successfully portray themselves simply as citizens demanding more democracy and recognition, the Turkish State's capacity to exclusively pursue a campaign of repression might well reach its limit." ${ }^{29}$ According to the author, the PKK has in fact pursued such a strategy since 1995 but has never achieved a substantial outcome. By the time Romano's book was published, however, competition among nationalist and Islamic Kurdish groups was nascent and Öcalan's thesis of Türkiyelileşme [co-existence in a democratic Turkey] did not yet form an organizational body within the larger ethno-nationalist movement.

Following Romano's social movement perspective, a number of scholars have provided rich descriptions of pro-Kurdish activist identity in transformation. Nicole Watts's Activists in Office, for example, highlights the need for a relational perspective to grasp how Kurdish activists seek to evoke pro-Kurdish identity:

Conceptualizing movements as part of a relational dynamic encourages us to explore the variety of ways that movement activity may affect different movement goals and sets of relations. It also discourages us from the common tendency to conflate ethnic communities with ethnopolitical movements by explicitly disentangling this relationship ... Ethnopolitical movements ... don't just seek policy changes from the target state but are also often involved in nation-building projects themselves. Like 
nationalizing states, they seek homogenizing categorizations (e.g., "Kurds are persecuted," or "The Irish want a united Ireland") and try to evoke generalizations to create a more firmly delineated "we." Despite the very real sacrifices activists make to further their movements, this creates deeply ambiguous and often conflicted relations with the communities affected by such activities, as well as with authorities, who are competing with movement activists for authority over the same population..$^{30}$

Examining pro-Kurdish municipalities in Southeastern Turkey, Watts brilliantly describes how Kurdish activists utilized electoral politics in order to gain access to legal and administrative resources that were unavailable through armed contention. Akin to Watts, Emre Uslu employs a social movement perspective to explain both the PKK's transformation and politicization of Kurdish Islamic identity. ${ }^{31}$ According to Uslu, tribes and religious networks are also mobilized by pro-ethnic entrepreneurs similar to the PKK movement. Uslu's examination of Hizbullah in particular is remarkably rich.

Another notable study is Cengiz Güneş's recent book The Kurdish National Movement in Turkey in which symbolic resources of PKK mobilization are closely analyzed. For Güneş, reinvigoration of Kurdish culture and music was crucial in the PKK's appeal to the masses. Popular nationalist myths such as Kawa the Blacksmith, who claimed to lead Medes' liberation war against the Assyrian empire, are reconstructed in narration of the PKK's rebellion in the modern era. Thus, the Medes are not only constructed as ancestors of Kurds but also pioneers of the PKK guerilla fighters. ${ }^{32}$ Likewise, Güneş describes how the myth of Newroz was reinvented as "Kurdish" new year despite its celebration among Persians, Azerbaijani Turks, and other nations in the Middle East on 21 March, the spring equinox:

The PKK reactivated the myth of Newroz to construct a contemporary myth of resistance centered primarily on the PKK inmates' resistance in the Diyarbakır Prison during the early 1980 os and its ongoing struggle. The PKK's construction of a temporary myth of Kurdish resistance to represent its struggle and the romanticizing of its guerilla war against the state enhanced its hegemonic appeal by bringing the myth of resistance into reality. ${ }^{33}$ 
According to Güneş, the PKK's engagement with Kurdish cultural repertoires has paved the way for ideological and discursive transformation in the Kurdish nationalist movement.

A common characteristic of the aforementioned studies is their application - whether explicit or implicit - of the "dynamic mobilization" model, introduced by Doug McAdam, Sidney Tarrow, and Charles Tilly in their most ambitious work, Dynamics of Contention. This scholarship is worth discussing at length here as it remains the dominant perspective among scholars who combine Kurdish studies and ethnic mobilization.

"We come from a structuralist tradition," wrote McAdam, Tarrow, and Tilly in Dynamics of Contention, "(B)ut in the course of our work on a wide variety of contentious politics in Europe and North America, we discovered the necessity of taking strategic interaction, consciousness, and historically accumulated culture into account." The authors go on to develop this thinking along lines of the interpersonal:

We treat social interaction, social ties, communication, and conversation not merely as expressions of structure, rationality, consciousness, or culture but as active sites of creation and change. We have come to think of interpersonal networks, interpersonal communication, and various forms of continuous negotiation - including the negotiation of identities - as figuring centrally in the dynamics of contention. ${ }^{34}$

Such a move toward a relational, dynamic view of social action is encouraging, especially for those who criticize the structuralist bias in the study of mobilization. ${ }^{35}$ McAdam, Tarrow, and Tilly highlight their approach to collective identity as relational because humans "actually live in deeply relational worlds," and they argue, "If social construction occurs, it happens socially, not in isolated recesses of individual minds. ${ }^{{ }^{36} 6}$ The authors' discussion of Hindus and Muslims in Pakistan is in congruence with the emerging boundary-making approach in ethnic politics, ${ }^{37}$ which aims to go beyond the essentialism vs. constructivism debate.

In chapter 6, "Transformations of Contention," McAdam, Tarrow, and Tilly discuss the issues of violence and conflict. They criticize competing

For thorough criticisms of the structuralist bias, see Polletta 1999; Goodwin and Jasper 1999.

37 For applications of the boundary-making approach to ethnic politics, see Wimmer 2008; 2013 . 
paradigms of rationalist and historical institutionalist perspectives in their approach to the role of individual incentives and institutional compromises in bringing social change. "(B)oth accounts largely ignore the enormous amount of contentious politics that preceded and accompanied each episode, as well as the mechanisms of political change and conflict that created new actors and new identities, and transformed institutional politics. ${ }^{38}$ The authors suggest focusing on episodes of contention through useful meso-level processes (what they call "mechanisms") such as brokerage, identity shift, radicalization, and convergence.

The most valuable aspect of the dynamics mobilization model is its explicit recognition of deficiencies in the classical social movement agenda. For example, political process theory explains radicalization, moderation, and other political orientations as "by-products" of political opportunity structures. As Andrew Walder notes, structuralist accounts consider collective violence "a product of the organization of the regime and the strategies and organizational capacities of the two sides." ${ }^{39}$ The structuralists, thus, neglect some crucial meso-level dynamics such as the activist perception of social structural elements, ${ }^{40}$ cross-cutting cleavages that impede or encourage ethnic violence, ${ }^{41}$ ideological/religious commitment to non-violence, ${ }^{42}$ and movement activist "know-how" or "taste" for defiant tactics. ${ }^{43}$ Although Dynamics of Contention does not offer substantive solutions to problems in structuralist perspectives, its serious attention to social and relational processes is noteworthy.

Perhaps the major problem with the dynamic mobilization model is its state-centered assumptions. Contentious politics are primarily regarded as episodes of contention with the state. "By contentious politics we mean," the authors elaborate, "episodic, public, collective interaction among makers of claims and their objects when at least one government is a claimant, an object of claims, or a party to the claims. ${ }^{144}$

A critical reader observes that this definition would purposefully exclude studies of contention "between a social movement and a countermovement (with the government as a third party), or an interaction between a social

McAdam, Tarrow, and Tilly 2001: 161.

Walder 2009: 404. See, for example, White 1989, Boudreau 1996, and Almeida 2008.

For this line of criticism, see Kurzman 1996; Goodwin 2006.

41 For impediment, see Mazrui 2000; for encouragement, see Fox 2002.

42 See, Nepstad 2004, 2008.

43 Two significant works in this growing literature are Jasper 1997 and Crossley 2003.

44 McAdam, Tarrow, and Tilly 2001: 5 . 
movement and its wider social environment." ${ }^{15}$ This negligence is a serious oversight for a framework that claims a relational approach. It also raises the question whether the authors really go beyond the traditional structuralist assumptions that plague political process theory. Armstrong and Bernstein rightly contend that "challenges directed at states may not reveal general social processes or mechanisms but processes and mechanisms that are specific to a particular institution or type of institution." ${ }^{36}$

Consider, for example, the mechanism of certification which is introduced as a "powerful selective mechanism in contentious politics because a certifying side always recognizes a radically limited range of identities, performances, and claims. ${ }^{147}$ One would be tempted to apply this notion in studying revolutionary activists' reputation work to get validation in the larger society. By definition, however, certification refers to "validation of actors, their performances, and their claims by external authorities," putting the state at the core in power relations. ${ }^{48}$ This, of course, does not mean that the mechanism is not useful; instead, we are still in need of finding and explaining similar mechanisms wherein the state is not central to the analysis.

For this very reason, for example, competing PKK and Hizbullah activists' subversive strategies cannot benefit from the discussions in Dynamics of Contention which rely on a "polity model" similar to earlier structuralist approaches. As Jack Goldstone reminds us, the polity model erroneously "emphasizes conditions relating to states" and neglects the crucial role of "counter-movements, allied movements, critical economic conditions, global trends and conjunctures, and various publics. ${ }^{.49} \mathrm{~A}$ feasible alternative is to search for "a model of society and power that renders challenges to nonstate institutions comprehensible." ${ }^{\circ}$

Despite deficiencies in Dynamics of Contention,$^{51}$ the leading social movement scholarly orientation toward the relational approach is promising.

45 Rucht 2003: 114. For similar criticisms, see Taylor 2003: 124.

46 Armstrong and Bernstein 2008: 80.

47 McAdam, Tarrow, and Tilly 2001: 158.

48 Ibid. Emphasis added.

49 Goldstone 2004: 356.

50 Armstrong and Bernstein 2008: 80.

$5^{1}$ A number of critics severely questioned if the "dynamic mobilization" model goes beyond the structuralism, finding Dynamics of Contention "reads like it was written by a committee that is not quite sure of its agenda" (Oliver 2003:120), "not totally clear to whom" it is addressed (Diani 2003: 112), "unfinished" (Koopmans 2003: 116) and "confusing" (Goldstone 2010: 363 ). Moreover, the authors' peculiar definition of "mechanisms" was found dubious. See Koopmans 2003 and Oliver 2003 . 
In fact, the later works of Charles Tilly show his most recent shift toward relational sociology. Calling for a "relational realism," Tilly's recent books develop a new perspective that is "close to a kind of nonteleological dialectic, akin to American pragmatism or to the dialogic theories of the Russian literary theorist Mikhail Bakhtin. ${ }^{22}$ Why and Credit and Blame are most engaged with the emerging literature on the processes of social boundary-making, inter-actor competition, and reputation work in politics. ${ }^{53}$ In Trust and Rule and Democracy,54 Tilly argues that trust networks should "be integrated into public politics through a relatively open state structure" because "local us-them boundaries are potentially compatible with democratization., ${ }^{55}$ Studying the role of trust in a relational perspective would properly place "communication, including the use of language, at the heart of social life. ${ }^{56}$

Following Tilly's advice, this book examines the role of Kurdish activists' reputation building, among other factors, in making up the trust networks. Charity organizations of competing Kurdish activists, for example, are not simply driven by electoral competition - as political clientelism theory would suggest-; instead, it is a "group-making" strategy that aims to gain the "trust" of the constituency. These organizations not only benefit moderates who participate in institutionalized politics, but they also affect the radical flanks. ${ }^{57}$

52 Krinsky and Mische 2013: 17. According to John Krinsky and Ann Mische, this is why Charles Tilly's later works draw heavily upon examples from political ethnography as a method that best fits with the relational approach. They aptly quote Tilly (2006b: 410): "Ethnography engages the analyst in looking at social processes as they unfold rather than reasoning chiefly from either the conditions under which they occur or the outcomes that correlate with them."

53 Tilly 2006a, 2008. His latest articles, "The Blame Game" and "Another View of Conventions," posthumously published in The American Sociologist, also engaged in similar themes (Tilly 2010a, 2010b).

54 Tilly 2005,2007 .

55 Cited in Krinsky and Mische 2013: 17.

56 Tilly 2005: 24. Jack Goldstone (2010:365) nicely captures Tilly's critical shift in these works: "Tilly also recognized that the relations in trust networks can weaken and segregate in times of crises, and that states can react with coercion as well as consultation. Thus he notes that there can be both democratization and de-democratization depending on circumstances. Democratization is thus not an inevitable march across categories of government, but the outcome of multi-level negotiations among diverse actors. By developing this theory of how democracy comes not from capitalism or urbanization or other large impersonal processes, but from the gradual building of trust between citizens and state actors, Tilly seemed determined to turn his earlier work upside down."

57 Similarly, we cannot examine trust without paying sufficient attention to emotions, which are largely ignored in the dynamic mobilization approach. For a comprehensive review and criticism, see Jasper 2011a. Consider Kurdish Hizbullah's demonstrations in the wake of the Danish cartoon controversy. It was the first mass protest in Diyarbakır organized by an Islamic movement, mobilizing hundreds of thousands into the streets. Among the protestors were a 


\section{The Argument of the Book}

In this book, I explore how grassroots activists transform an intractable ethnic conflict from a culture of violent enmity to a culture of polite competition. The activists under study are not from a single pro-ethnic movement; instead, they belong to different social movements that have rigid boundaries and histories of severe clashes among them. In what follows, I provide a new conceptualization of these social movements as "rivals," defining their relations as "rivalry."

Existing literature characterizes the relations among social movements as friends or enemies. Some scholars note that a variety of movements can form a "movement family," i.e. "a set of coexisting movements that, regardless of their specific goals, have similar basic values and organizational overlaps and sometimes even join for common campaigns. ${ }^{15} 8$ This type of friendship was evident in the alliance between abolitionist and suffrage movements as well as relations among leftist progressive movements in the 1960 s and $705 .{ }^{59}$ Studies on movement-counter-movement dynamics, on the other hand, indicate how opposing mobilizations could engage in brutal violence and the slaughter of adversaries. ${ }^{60}$ Notable examples include the adversarial relationship between the Christian Right and the LGBT movements as well as the pro-choice and the pro-life movements. ${ }^{61}$

large number of supporters of the PKK-led Kurdish movement. How could we make sense of Hizbullah's pro-Islamic protests with respect to Turkey's Kurdish issue? As chapter 5 argues in detail, Hizbullah's public demonstrations provided them with an identity re-construction from violence to non-violence, with the aim of partly redressing their public image. At a time when many members of the group were still behind bars in Turkish prisons, these attempts at public symbolism were indeed forms of reputation work to establish trust within the movement as well as trust in the larger public. As Hizbullah activists seek their place in the emerging civil society, these demonstrations have become a collective ritual, repeated each year in the name of commemorating the Prophet. In the larger picture, Hizbullah's search for its soul as it moves toward moderation has influenced the PKK's ideological shift as well as the Turkish state's strategic engagement with a multifaceted Kurdish movement containing Islamic and ethnic elements. These exchanges have been significant in the construction of a competition culture, and thus, they have helped to transform the ethno-political conflict. For elaboration and discussion, see chapters 4 and 5 .

58 Della Porta and Rucht 1995: 232.

59 For the connection between abolitionist and suffrage movements, see DuBois 1978. For the leftists movements' collaborations, see McAdam 1988; Meyer and Whittier 1994.

60 See, for example, Turner and Killian 1972; Mottl 1980; Zald and Useem 1987; Meyer and Staggenborg 1996.

61 For an in-depth account on the adversarial relations between the Christian right and the LGBT movements, see Fetner 2008. On the fight between the pro-choice and the pro-life movements, see Munson 2009. 
I suggest a third possibility - that is rivalry, as a construct of the intermovement relationship. I use the term "rival movements" to mean two or more social movements that are actively engaged in challenging the dominant power structure as well as one another. ${ }^{62}$ The rival movements neither try to exterminate each other as seen in opposing movements nor do they show elements of friendship in their relations. Instead, they engage in a fierce competition for material and symbolic resources.

Competition is a key dynamic among social movement activists. Despite the lack of attention to inter-movement competition, intra-movement competition is well studied in the literature. Social movement scholars point out how social movement organizations compete for the distribution of resources such as money, time, energy and skills. ${ }^{63}$ Activists within the same movement also compete for allocation of symbolic resources such as prestige. ${ }^{64}$ Scholars analyze how competition among social movement organizations is influenced by macro-level changes ${ }^{65}$ intra-class struggle,${ }^{66}$ and religious affiliation. ${ }^{67}$ The existing literature on intra-movement competition would provide insights in conceptualizing inter-movement rivalry.

My definition of rival movements is a symbolic interactionist classification. Rival social movements are neither innately nor permanently "rivals." When Kurdish ethno-nationalists and Kurdish Islamists, for example, were locked in deadly violence and rage against each other during the 1990s, their relationship was more likely to be of the opposing movement type (i.e. movement versus countermovement) where elements of enmity dominate. As demonstrated in this study, they transformed their relationship into a competitive one in the past decade: that is, they have accepted each other's right to exist in the Southeast region and have started to open competitive civic organizations in order to shape the views of the Kurdish public. In other words, friendship, enmity, and rivalry among movements do not refer to definitive roles or qualities that social movements attribute to themselves. Following Alexander Wendt ${ }^{68}$ I treat different roles that

62 The term "rival movements" was first employed by Charles Tilly (1999:268). Yet, in this short article, Tilly did neither define nor develop the term conceptually.

63 See Zald and McCarthy 1980; McCarthy and Zald 1977; 2001.

64 See Benford and Zurcher 1990.

65 Minkoff 1995, 1997, 1999; Olzak and Ryo 2007.

66 Stepan-Norris and Zeitlin 2003; Stepan-Norris and Southworth 2010.

67 Trejo 2009.

68 Alexander Wendt's (1999) Social Theory of International Politics remains one of the most cited works in the field of International Relations. Wendt analyzes how the nation state system is socially constructed through three cultures of anarchy, i.e. friendship (Kantian), enmity (Hobbesian), and rivalry (Lockean). 
social movement activists take as property of a social structure, instead of identifying various roles as properties of agents. Thus, friendship, enmity, and rivalry are three distinct interpretive systems in which various roles dominate culturally.

\section{How Does Meaning-Making Matter?}

Social movement scholars have become better equipped to acknowledge the significance of interpretive processes, especially after the cultural turn in the social sciences. In the introduction to the second edition to his pathbreaking study, Doug McAdam notes the following:

The ongoing interpretation of events by various collectivities shapes the likelihood of movement emergence, as it shapes all of social life. Indeed, these continuous processes of sense-making and collective attribution are arguably more important in movements insofar as the latter require participants to reject institutionalized routines and taken-for-granted assumptions about the world and to fashion new world views and lines of interaction. And yet, for all their importance, these crucial interpretive dynamics are largely absent from our theories of the origins of movements and other forms of contentious politics. There is virtually no mention of these processes in the theoretical work on ethnic conflict, or the dominant structuralist approach to comparative revolution. One is left, in both cases, with the distinct impression that structural changes ... give rise to contention without regard to these intervening interpretive processes. $^{69}$

Although his primary focus is on social movement emergence, McAdam's criticism is applicable to the literature on inter-movement relations. We know, for example, movement vs. counter-movement hostilities increase when the state enables but does not satisfy challengers..$^{70}$ However, we are still in need of grasping what McAdam calls "intervening interpretive processes." Structural changes and political opportunities matter, but we also need to know how these changes are impacting local contexts through cultural mechanisms and interpretive processes. Regarding the Kurdish case examined here, changes in the Turkish political context after the 
European Union reforms are crucial in explaining rival movements' ability to compete with one another, though they are not enough to explain which mechanisms, processes, and activists engage with their rivals.

Although there is a growing literature that challenges the dominant structuralist research paradigm in social movement theory, ${ }^{71}$ processes of meaning-making among activists are under-examined. As Charles Kurzman nicely captures,

\begin{abstract}
While the cultural turn conquered social movement studies, some of its most radical implications were lost in the process. Meaning-making was assimilated into an analytic framework of causes and effects that was built for earlier conceptual tools. In effect, meaning-making has been turned into a set of independent variables. Does a group have a strong sense of solidarity? Check. Does the movement have a message that resonates with core values? Check. Does the repertoire of protest match the structure of political opportunities? Check..$^{22}$
\end{abstract}

This book analyzes how the process of meaning-making is in constant play when social movement activists compete for recognition, prestige, and political power.

Committed to an interpretive approach, I argue that inter-movement rivalry, like all patterns of social movement relations, is socially constructed, inter-subjectively understood, institutionally supported, and collectively reproduced among movement activists. The patterns of movement relations cannot be reduced to individual activists' perceptions and behavior; instead, they become an interpretive system that shapes agent behavior. ${ }^{73}$

As readers will notice in the following chapters, by giving up brutal violent engagement, the movements under study have constructed a culture

71 Most notable works include Polletta 1997, 1999, 2004, 2006; Goodwin and Jasper 1999; Goldstone 2004; Mees 2004; Van Dyke, Soule, and Taylor 2004; Armstrong and Bernstein 2008; Bernstein 2008, 2013.

72 Kurzman 2008: 10.

73 The assumptions are well supported by scholars of social movements. Russell Curtis and Louis Zurcher (1974), for example, explained why social environments are significant for the operation of social movements. Despite their somewhat mechanical description, the authors make a distinction between "a hostile environment" and "a reinforcing environment." Building on their study, Bert Klandermans (1990) introduces the concepts of alliance and conflict systems to underline the importance of social movement activists' environment. Donatella Della Porta and Dieter Rucht (1995) further support these classifications and find that cooperation and competition appear to be major strategies for activists in an alliance system; whereas, bargaining and confrontation are basic strategies for activists in a conflict system. 
of rivalry after democratic reforms implemented by the Turkish government (2002-2004). As Alexander Wendt notes:

The Lockean culture has a different logic from the Hobbesian because it is based on a different role structure, rivalry rather than enmity. Like enemies, rivals are constituted by representations about Self and Other with respect to violence, but these representations are less threatening: unlike enemies, rivals expect each other to act as if they recognize their sovereignty, their "life and liberty," as a right, and therefore not to try to conquer or dominate them. ${ }^{74}$

The Kurdish case corroborates Wendt's claim. Although some hostilities are still ongoing, Kurdish civil society has become an open space for competition, and it is by no means comparable with the martial law era of the $1990 \mathrm{~s}$ when the Kurdish ethno-nationalists and Hizbullah were involved in a violent struggle. Both sides have come to an inter-subjective respect for each other's right to exist. ${ }^{75}$

I suggest that engagements of rival activists constitute a pattern of social relationship that helps transformation of violent conflict. Rival movements construct competition zones, what James Jasper calls "arenas," in order to enhance their influence on the larger society. ${ }^{76}$ I identify three primary mechanisms, which I call "processes of rivalry." These processes are resemblance, niche building, and strategic subversion.

Resemblance, the first process introduced in the book, refers to development of similar organizations that are run by the competing movements in the civil society. As rivals become aware of the new opportunities to expand their influence, they develop similar civic initiatives, and therefore, they resemble each other in the long run. David Meyer and Suzanne Staggenborg observed a similar process between opposing movements. The authors rightly argue that "once a movement enters a particular venue, if there is a possibility of contest, an opposing movement is virtually forced to act in the same arena." ${ }^{77}$ In Turkey's predominantly Kurdish Southeast region, the rival movements primarily resemble each other through charity organizations, all of which were established about the same time (i.e. soon after pro-Kurdish reforms in 2004).

74 Wendt 1999: 279 .

75 See, for example, the public statements of Abdullah Öcalan, the leader of Kurdistan Workers'

Party, about Hizbullah and the Gülen movement HDN 2010; Bugün 2011.

76 See Jasper 2004, 2006.

77 Meyer and Staggenborg 1996: 1649 . 
The second process, i.e. niche building, which occurs simultaneously, seems to contradict the first one. Niche building refers to the rival activists' efforts to specialize in certain fields that are not easily available to their competitors because of (a) lack of material resources, (b) an ideological misfit, and/or (c) reluctance to be represented in the particular field due to what I call activists' phronesis. In fact, through the lens of a strategic perspective, a niche building strategy never contradicts the processes of resembling. Instead of a structuralist perspective that assumes a direct link between available resources and organizational niche building, ${ }^{78}$ a multi-institutional politics perspective would locate these social movement organizations and available material resources within the larger cultural engagements they develop over time.

As James Jasper rightly notes, "(F)rom the structural perspective, it is sometimes difficult to see how players move among arenas, trying to enter those where their capabilities will yield the greatest advantages, or to see how new goals emerge and inspire players to form around them."79 Thus, neither access to the fields of competition nor resources should be taken for granted. Activists' constant interpretation of their positioning vis-à-vis their rivals suggests a relational sociology framework that defines the ontological stance of the multi-institutional politics perspective. ${ }^{80}$ Niche building provides activists further visibility in public and strengthens a social movement's positioning vis-à-vis its rivals, and even, at times, generates resources. Women's associations of the Kurdish ethno-nationalists, religious public events of Hizbullah, and education centers of the Gülen movement are examples of niche building efforts in the region.

Finally, social movements challenge their competitors through symbolic activism, or what I call strategic subversion. Strategic subversion refers to activists' collective attempt to claim symbolic resources such as religious repertoires and local historical figures in order to both strengthen their own prestige and harm the reputations of their competitors. Activists' moral performance and emotional strategies are crucial in symbolic contestation. ${ }^{81}$ Moreover, building a moral authority is especially significant in ethnic politics. Through strategic subversion processes, the pro-ethnic activists become what Gary Alan Fine calls "reputational entrepreneurs." ${ }^{82}$

78 See, for example, Minkoff 1999; Levitsky 2007.

79 Jasper 2015: 12; see also Jasper 2011b.

80 For "relational sociology," see Emirbayer 1997; Mische 2011.

81 For moral performance, see Eyerman 2006. For a comprehensive review of emotions and social movement strategies, see Jasper 2o11a.

82 Fine 2006: 405. 
Overall, the aforementioned processes together have shaped the nature of the intractable ethnic conflict in Turkey's Southeast. Pro-ethnic actors' strategies as well as identities are changed. As they engage in civil competition, their perception of "other" has become altered. Their relations have become visible to the public eye for the first time in modern Turkey's history, and this very reflective consciousness has paved the way toward a conflict transformation.

\section{Organization of the Book}

The book consists of nine chapters including this introduction. Putting the Kurdish issue in national and global perspective, Chapter 2 aims to give readers a historical background of the pro-ethnic actors under study, namely the Kurdish ethno-nationalist movement, Hizbullah, and the Gülen/ Hizmet movement. Chapter 3 analyzes critical events that have radically shaped Kurdish politics since 1999: (1) the capture of PKK leader Abdullah Öcalan (2) initiation of Turkey's European Union membership negotiations, (3) the events of $9 / 11$ and the War on Iraq, and (4) the rise of the Justice and Development Party (AKP) and its electoral victory in 2002. These two chapters set the stage for the ethnographic analysis to follow.

Chapter 4 outlines how rival Kurdish activists have constructed civil society competition and thus planted the seeds of conflict transformation in the region. The competition "arenas" in the emerging Kurdish civil society are linked with social movements' resources, ideological boundaries, and Kurdish activists' phronesis (practical know-how). In arenas where competition is feasible, rival activists resemble each other in their strategic path. If the competition is restrained in certain arenas, it enables some Kurdish activists to carve out their niche. When actors are in a symbolic fight, they engage in subversive techniques to construct their self-image through delegitimizing their rivals. I call these processes resemblance, niche building, and strategic subversion, which are examined in later chapters.

Chapter 5 explores how the PKK, Hizbullah, and the Gülen movements resemble one another through charity organizations while they strongly emphasize their differences through niche building. Criticizing mainstream approaches, such as with political clientelism theory, I argue that rival charity activism should be analyzed as a mechanism of reputation work in claiming Kurdish civil society. At the same time, the rivals are especially active in certain fields that are not easily available to their competitors. Each movement has different emphases in the civil society competition: the 
PKK privileges its women's organizations, Hizbullah focuses on religious associations, and the Gülen specializes in educational institutions.

In Chapters 6, 7, and 8, I examine how rival activists transform Kurdish civil society as a result of their reputation work in the symbolic realm. I specifically discuss the importance of "symbolic localization" in transforming the conflict. As an overarching concept, symbolic localization refers to the process of identity change as local, cultural repertoires are embraced by radical activists. The PKK's increasing engagement with Islamic culture and Hizbullah's localization through Kurdish language are remarkably significant developments. These three chapters describe how rival activists have become involved in strategic subversion, a process in which the claiming party reconstructs its identity through de-legitimizing its rivals' identities.

Chapter 6 analyzes the competition to define "Kurdish Islam" in the region. This chapter demonstrates how the PKK has experienced a discursive as well as ideological transformation in its relationship with local Islamic culture. Local Islamic figures such as Said Nursi have become cultural spaces for contestation among rival Kurdish activists. Chapter 7 sheds light on pro-Islamic activists' various projects involving the Kurdish language and the increasing "war on words" in the civic sphere. Kurdish ethno-nationalists, as a reaction, call for mass protests for education in the mother tongue. This type of civil society competition has brought more transformations for pro-Islamic actors as they further localized in their ethnic tone.

Chapter 8 examines competing narratives of the Turkish "deep state," also known as Ergenekon. The Ergenekon investigation has initiated a public awareness of the illegal state operations in the region. As victims of the secularist military regime, the pro-Islamic AKP and Gülen supported the investigation, and thus, Turkish citizens have begun to hear intriguing stories about so-called "terrorists" for the first time. Having roots in both Turkish and Kurdish constituencies, these pro-Islamic actors have diminished the long imposed official "narrative violence" on the Kurdish issue. From Hizbullah's novels to the PKK's public memory projects, proKurdish narratives were an essential part of reputation work: rival activists re-constructed their self-image through "distinction" among other Kurds. This chapter shows how narratives play a remarkable role in symbolic localization of competitor Kurdish activists.

In Conclusion, I discuss how a Multi-Institutional Politics (MIP) approach provides better conceptual tools compared to classical approaches in studying ethnic mobilization, violence, and conflict transformation. 


\section{$2 \quad$ Kurdish Movements in the Southeast}

I leave it to God's wisdom

The Kurds in this world's state

Why are they deprived of their rights?

Why they all are doomed?

See, from the Arabs to the Georgians

Everything is Kurdish and, as with a citadel,

The Turks and the Persians besiege them

From four sides at once

And they both make the Kurdish people

Into a target for Fate's arrow

- EhmedêXanî (1651-1707)

Until recently, all elementary school children in Turkey used to recite a nationalist oath every morning. Written way back in 1933, "Our Pledge" was also chanted by Kurdish students. "I am a Turk; I am honest; I am hard-working," begins the oath with an interesting ending: "Let my entire being serve as a gift to Turkish existence. How happy is the one who says I'm a Turk!"'

The motto, "How happy is the one who says I'm a Turk," uttered by the father of the modern Turkish Republic, Mustafa Kemal Atatürk, is very telling about the nature of nationalist indoctrination. ${ }^{3}$ The Republican

1 Quoted from Kreyenbroek and Allison 1996: 10.

2 Andımız, Our Pledge, was written by Reşit Galip, who served as a minister of education (1932-33). The final sentence, "Happy is the one who says I'm a Turk!" which belongs to Mustafa Kemal Atatürk, was later added to the student oath. Atatürk first expressed the dictum in his $10^{\text {th }}$ Year Address (Onuncu Yll Nutku), a famous address given for the $10^{\text {th }}$ anniversary of the foundation of the Republic (Oct. 29, 1933). After eight decades, in October 2013, the Turkish government decided to remove the pledge from the curriculum.

3 With a population between 25 and 30 million, Kurds are the largest ethnic minority in the Middle East. Turkey remains the home of almost $50 \%$ of all Kurds while the other half are dispersed across Iraq, Iran, and Syria. It should be noted that the debates around the Kurdish population are politically contested. Since no census data on Kurdish demographics is available, scholars are divided over the issue. McDowall (1997) and Romano (2006) note that Kurds constitute $23 \%$ of Turkey's population, which means almost 17 million. On the other hand, Yavuz and Özcan (2006) endorse Andrews's (2002) study, which estimates the Kurdish population at about 6 million, making $9 \%$ of the total population in Turkey. I find Sener Aktürk's (2011) study that estimates Kurds as constituting $15.7 \%$ of the total population more realistic. KONDA, a Turkish poll agency, supports this view, giving an estimate of around 14.7\% (KONDA 2011). 
elite established the new regime on the basis of secular nationalism. Their understanding of secularism, however, was a peculiar one; that is, subduing Islamic identity for the regime's interests instead of eradicating it totally. Those who lived in Turkey were officially regarded as "Turks" unless they were non-Muslims. The only official minority in the country, i.e. non-Muslim segments of society, was forced to migrate to Greece and Bulgaria (in exchange for the Muslim population who were then considered to be Turks) in the early years of the Republic. Although the founders of the modern Republic were ardent supporters of secularism, they utilized the common Islamic background of various ethnic groups in order to construct a modern Turkish identity. Thus, all Muslims including Kurds, Arabs, and Circassians were officially declared "Turks."

In constructing a chauvinist historiography, the new Republican elite developed the Turkish Historical Thesis (Türk Tarih Tezi) and the Sun Language Theory (Güneş Dil Teorisi), both taught as objective facts in high schools in the 1930s. The Turkish Historical Thesis suggested that all major civilizations have their roots in Central Asia, the land of Turks. Likewise, the Sun Language Theory proposed that Turkish is the source for all major languages in the world. Although these nationalist theories are no longer in use, their legacy has remarkably shaped both Turkish and Kurdish ethnic identities. ${ }^{5}$

As late as the 1980s, the very existence of Kurds was denied by Turkish state officials who used to refer to Kurds as "mountain Turks." ${ }^{\prime}$ The post-1980 military government intensified propaganda campaigns about the Turkishness of the Kurds through various publications such as Anadolunun Ilk Türk Sakinleri: Kürtler [The first Turkish inhabitants of Anatolia: the Kurds] and Türkistanlı bir Türk Boyu: Kürtler [A Turkish tribe from Turkistan: the Kurds].7 "What separatists call Kurds are the Turkish people who used to live in the mountains," stated the White Book that was published by the Turkish General Staff after the 1980 coup. "Kurd is the sound that emerged when these people walked on the snow." ${ }^{8}$ Until 1991, speaking Kurdish in public could have resulted in fines or prison sentences since public expressions of Kurdish identity were equated with "separatism" or "terrorism."

4 Yildız 2001: 133. For the founding father Mustafa Kemal Atatürk's thoughts on Kurds, see Yeğen 1996, 1999; Mango 1999. For his policy toward the key Kurdish city Diyarbakır, see Çağlayan 2014.

5 Hirschler 2001: 147; Beşikçi 1977; Ersanl1 2003.

6 For a very early work on this expression, see Elphinston 1946.

7 These works, respectively, are Seferoğlu 1982 and Taneri 1983.

8 See Dündar 2009. 
Figure 2.1 One of the major inner-city roads in Diyarbakır where Ataturk's dictum "How happy is the one who says I'm a Turk" was launched by Turkish military after the 1980 coup. The sign was removed on November 7, 2013.

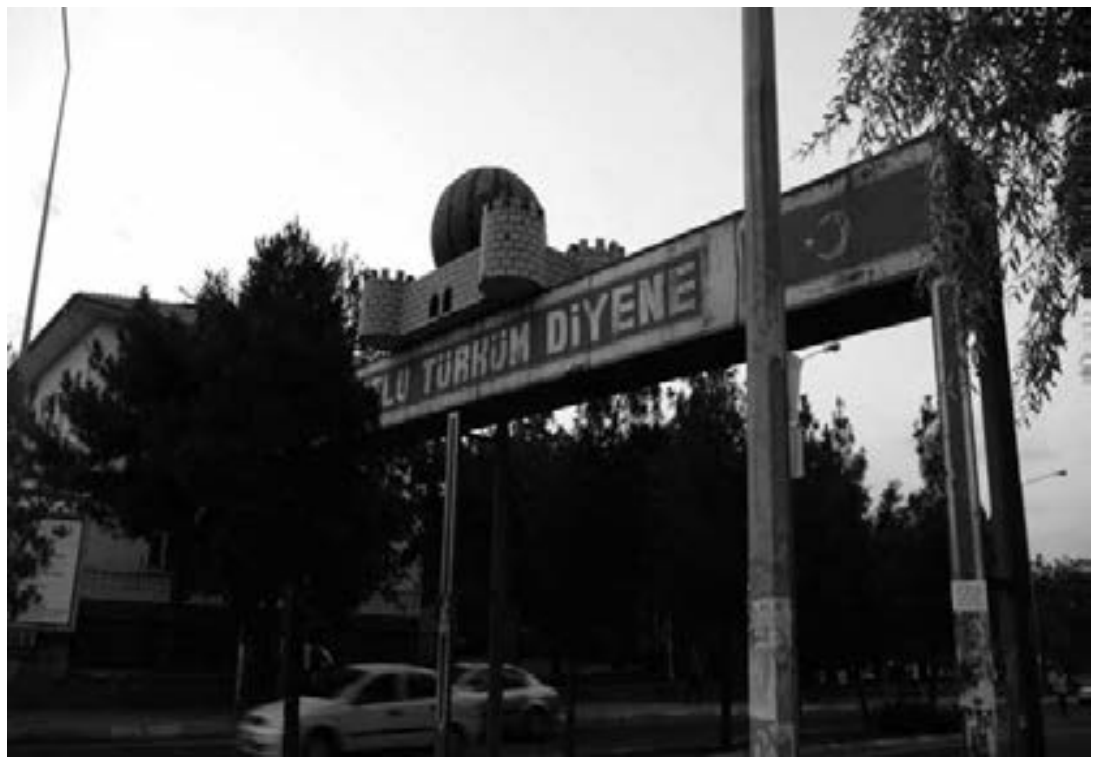

Photograph by author, July 16, 2009

Diyarbakır Prison, notorious for inhumane tortures, had become a type of concentration camp for Kurdish activists after the 1980 coup. Many of the detainees joined the PKK rebels after their release. ${ }^{9}$

Under these political circumstances, it is not hard to understand why Kurdish ethnic and Islamic movements arose in the Southeast. The PKK-led Kurdish ethno-nationalist movement, Hizbullah, and the Gülen movement have long been three major grassroots actors in the region.

\section{The Kurdish Ethno-Nationalist Movement}

Kurdistan Workers' Party, generally known by its acronym PKK, has been the leading organization for Kurdish ethno-nationalism. Founded as a Marxist revolutionary group in 1978, the PKK launched a guerrilla war against the Turkish State during the 1980s. In three decades, the fight left more than 40,000 people dead, tens of thousands were injured and 
kidnapped, and hundreds of thousands were forced to migrate to larger cities in Turkey. ${ }^{10}$

The PKK's cause for Kurdish freedoms has rapidly grown bigger than itself. In the early 199os, pro-Kurdish parties began to emerge as non-violent elements for Kurdish ethno-nationalism. Especially after the imprisonment of the PKK's charismatic leader Abdullah Öcalan, the movement has significantly become active in the political realm. ${ }^{11}$

The Turkish Constitutional Court repeatedly banned pro-Kurdish parties from politics for allegedly being the PKK's propaganda arm. Until recently, the political platform was the Peace and Democracy Party, BDP, which became the flagship political organization after the closure of its predecessor, the Democratic Society Party, DTP, by the Constitutional Court on December 11, 2009. The DTP replaced the Democratic People's Party, DEHAP, which had earlier replaced the People's Democracy Party, HADEP. The chain goes back to the People's Labor Party, HEP, which was formed in $1990 .{ }^{12}$ In 2014, upon Öcalan's request to strengthen Kurds' political alliance with the Turkish left, the Peace and Democracy Party (BDP) split into two distinct groups: the Democratic Regions' Party (DBP), which competes in local elections and represents the municipalities, and the People's Democratic Party (HDP), which contests nationwide general elections.

Although the PKK and the pro-Kurdish political parties are independent in terms of their organizational structures, the majority of the Kurdish parties' members have maintained their close relationship with the PKK because the pro-Kurdish constituency still perceive these parties as "surrogate PKK."’3 In my interviews with three Kurdish party deputies in the Turkish Grand National Assembly in Ankara, along with my observations of some deputies' speeches in Diyarbakır public demonstrations, I notice two different narratives concerning the PKK. In Ankara, they argue that the State should strategically recognize the PKK in order to achieve peace and democracy in the region; whereas in Diyarbakır, they cherish the PKK's

10 There is a massive literature on the PKK movement from a variety of different perspectives. Most often cited works include White 2000; Romano 2006; and Marcus 2007. For a most recent book exclusively on the PKK, see White 2015.

11 The Kurdish ethno-nationalist organizations includes the Kurdistan Students Association, the Free Youth Organization, the Free Women's Organization, the Human Rights Association (İHD), and a myriad of media outlets, including Gündem daily, Roj TV, IMC TV, and Firat News Agency. All of these organizations are closely tied to the PKK.

12 For an in-depth account on first pro-Kurdish parties in Turkey, see Watts 1999. Throughout the book, I often use the term "pro-Kurdish party" for all the parties aforementioned in order to help non-specialized readers.

13 Watts 2006: 127. 
Figure 2.2 A typical pro-Kurdish party rally in which PKK flags and Öcalan figures are cherished

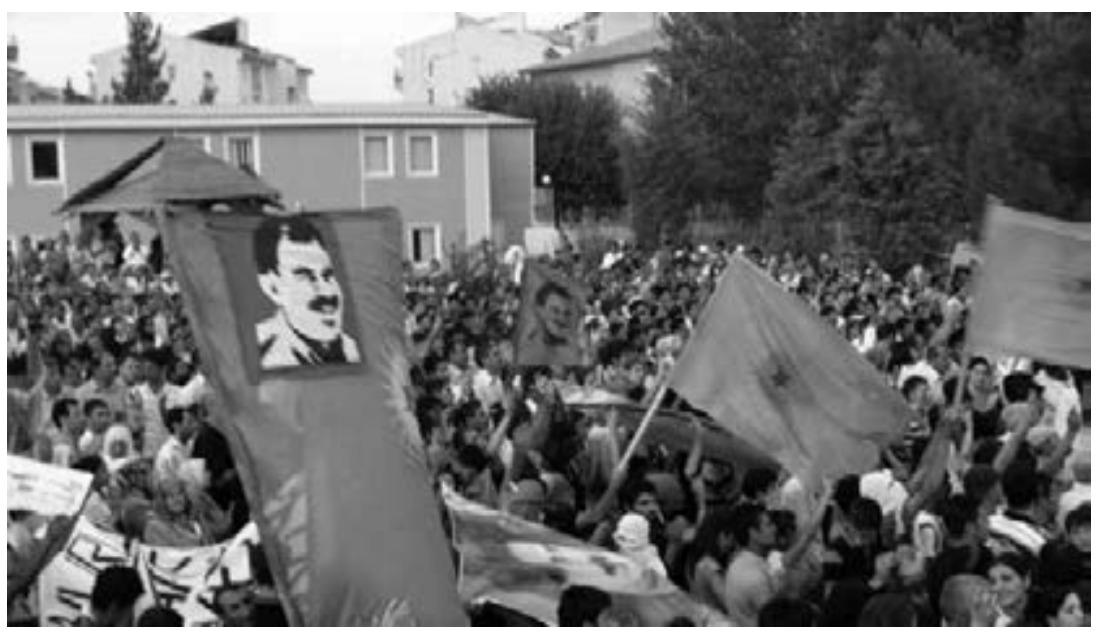

Photo by the author, Diyarbakır, July 15, 2009

at times violent struggle, claiming that the guerillas have deserved to be taken into account due to their unyielding fight. Many politicians often face criminal charges because of their public speeches. ${ }^{14}$

Originally formed as a student-based clandestine organization, the PKK initially called for an independent Kurdish socialist state by employing violent measures against 'collaborators' with the Turkish regime, i.e. Kurdish notables and tribal leaders with a stake in the existing political system. ${ }^{15}$ The PKK has been led by newly urbanized and university-educated Kurds who do not have tribal ties. In this sense, the PKK insurgency has been fundamentally different from the tribal resistance of Kurdish leaders, who use kinship ties and state resources to get elected to the parliament and to maintain their support base.

Thus, unlike tribe-based "occasional Kurds," who have no major problems with the State other than refining their status in society, the PKK movement is "blurred by regional, sectarian and class identities, engaging a dual rebellion - against both the traditional structure of Kurdish society and the Kemalist state system." ${ }^{\prime 6}$ The PKK has striven for a radical goal: to establish an independent state for the Kurdish nation, or alternatively, to form a binational Turkish-Kurdish federation. 
In the past decade, the PKK has redefined itself in the emerging Kurdish civil society. The pro-Kurdish parties have increasingly become powerful voices for Kurds, demanding constitutional changes for the recognition of Kurdish identity and cultural citizenship. The continuous success of the pro-Kurdish parties in local elections paved the way for many activists to become public officials. The control of many local municipalities in Southeast Turkey further empowered Kurdish ethno-nationalism, introducing new spaces of opportunity and resources.

\section{Hizbullah in Turkey}

In addition to the PKK, Hizbullah (The party of God) has long been a revolutionary movement in the region. ${ }^{17}$ The 1979 Iranian revolution, the development of the Syrian Muslim Brotherhood's Kurdish branch, the 1982 Hama rebellion in Syria, and global Islamic revivalism all contributed to the formation of Hizbullah in Diyarbakır in the early $1980 .{ }^{18}$ Unlike the renowned Lebanese Hizbullah, the group is a Sunni movement, often called Cemaat (the Community) by its members. ${ }^{19}$

Hizbullah emerged as an influential pro-Kurdish movement only after its fight against the PKK in the early 1990s. Although there were many Islamic groups, including Sufi mystic orders and brotherhoods, in the region, ${ }^{20}$ Hizbullah powerfully organized in high schools and mosques. The

17 Hizbullah in Turkey is totally different from Hizbullah that operates in Lebanon. Some scholars called the movement "Kurdish Hizbullah" (Yavuz and Özcan 2006; Uslu 2007), whereas some others used "Turkish Hizbullah" in their writings (Aras and Bacık 2002; Levitsky 2003; Laçiner 2007). I avoid naming the movement Kurdish Hizbullah since another Hizbullah presence exists among the Iraqi Kurds and it may give a false impression that the movement is a Kurdish separatist organization. Also, Turkish Hizbullah would not be appropriate because the overwhelming majority of activists are of Kurdish origin. Therefore, throughout the book, I stick to their plain name "Hizbullah."

18 A Hizbullah member told me that the Hama rebellion had a strong influence on Turkey's Sunni Kurds who have close relatives living in the region. Author's interview, Diyarbakır, July 25, 2009. 19 Tutar 2009. Çakır (2007:1) notes that Hizbullah followers never called themselves "Hizbullah." My interview data, however, dissents with this argument. In the words of an activist, "the Kurdish public in general" named the organization in the 199os because of "their appreciation of the group's unyielding stance against the PKK." Later, he added, the organization members accept the name enthusiastically. Moreover, Hizbullah's military leader Cemal Tutar's court defense indicates that the movement followers have long called themselves Hizbullah. See, Tutar 2009.

20 The Kurds' strong attachment to Islamic culture is well documented. See, for example, Van Bruinessen 1992, 2000; Akyol 2006; Çiçek 2008; Tan 2009. Major moderate Kurdish-Islamic 
group's armed struggle with the PKK in Kurdish cities such as Diyarbakır, Mardin, and Batman led to a common perception that it was supported by the Turkish State. ${ }^{21}$ Calling the PKK pejoratively Partiya Kafirin Kurdistan [Kurdistan Infidel Party], Hizbullah charged the Kurdish ethno-nationalists with serving Communism, murdering Muslims, and dividing the Kurdish Muslim community. Between 1991 and 1996, the bloody conflict between the two groups resulted in more than 1,000 casualties. ${ }^{22}$

In 1998, Hizbullah started to abduct, interrogate, and even murder those who left the movement as well as those who might be potential enemies. ${ }^{23}$ The notorious murders of İzzettin Yıldırım (the leader of a small KurdishIslamic Nur group) and Konca Kuriş (a vocal Muslim feminist) tarnished Hizbullah's reputation as an Islamist movement fighting only against the PKK. Soon afterwards, Hizbullah's top leader, Hüseyin Velioğlu, was killed in a police raid. Most Hizbullah activists either succeeded in escaping to other countries or were arrested on terrorism charges. These developments led Hizbullah to renounce violence and transform itself into a civic movement. After a few years of silence and shock, the movement activists began to establish civil society organizations in 2004.

Strikingly, both Hizbullah's leader, Hüseyin Velioğlu, and the PKK's leader, Abdullah Öcalan, were radicalized in Ankara instead of in their home towns. ${ }^{24}$ Similar to the Kurdish ethno-nationalist Marxism, Hizbollah's Islamism did

groups include traditional Islamic brotherhood networks such as Naqshbandi orders and Nur community. These groups emphasize their religious identity first and foremost, whereas they express their Kurdish identity when confronted with the imposition of Turkish-ness (Yavuz and Özcan 2006: 106). Such groups have long supported the center-right parties, most recently the AKP, primarily because of their disapproval of leftist Kurdish nationalism led by the PKK. 21 For Hizbullah's organizing structures among youth-illustrated with personal anecdotes-, see Kurt's 2015 recent monograph. There is strong evidence that the Turkish military supported Hizbullah against the PKK. Illegal operations of the Turkish military officers, however, included false-flag operations of both Hizbullah and the PKK, indicating that the Turkish counterterrorism units infiltrated both sides, and as a result, benefit from the ongoing bloody conflict in order to strengthen the OHAL regime, i.e. the military rule in the region. See chapter 8 for the illegal operations of the state.

22 Aras and Bacık 2002: 150. See also, Çakır 2001: 93-95. One of the Hizbullah leaders, who served ten years in prison, told me that the PKK threatened them and they had no other way out other than defend themselves. Yet, he also confessed that Hizbullah interrogated and executed those who were spying. The author's interview, Istanbul, June 5, 2009.

23 According to the Turkish police reports, the number of these individuals reached 6o, and the majority of these operations were held in the year 1999. For details, see Bal 2006.

24 Perhaps more strikingly, both were college students in the Department of Political Science at Ankara University, popularly known as Mülkiye because of its prestigious education to train civil servants such as governors and public inspectors. 
not stem from local Kurdish culture, long perceived as alien to the region. Since the movement did not publish any documents before 2004, there is little evidence of its ideological training in early years. The police intelligence records that were secretly collected from Hizbullah sermons indicate that the group utilized teachings of anti-Western figures such as Ayatollah Ruhollah Khomeini, Sayyid Qutb, Ali Shariati, and Abul Ala Maududi. ${ }^{25}$

In the past decade, movement activists have increasingly become more transparent as well as more pro-Kurdish, calling themselves mustazaf, i.e. the oppressed. Their charity organization, Mustazaf-Der (Association for the Oppressed), became the first public face of the movement until its closure in 2012 by a court order due to its alleged link with outlawed Hizbullah. ${ }^{26}$ After the closure, the movement took the path of legal political activism, establishing Hür Dava Partisi, Free Cause Party, which is often called by its acronym HÜDA-PAR due to its literal meaning: The Party of God, a Kurdish expression for the word Hizbullah in Arabic.

Only a year after its establishment, HÜDA-PAR participated in the 2014 local elections. Receiving 92,00o votes, the party emerged as the third major political party, following BDP/DBP and AKP, in the region. Despite not winning any mayoral post, the party signaled that it can attract conservative Kurdish votes. ${ }^{27}$ Such a level of success in their first election experience further encouraged Hizbullah activists to pursue party politics. Electoral competition has defined emerging new norms in engagement between Hizbullah and the PKK: before the elections, HÜDA-PAR members claimed that their electoral offices and party officials were under attack by PKK militants. ${ }^{28}$

The legalization of Hizbullah, however, has led some radical Islamists disenchanted with the movement to join the Islamic State, also known as Daesh. The leader of the Islamic State in Turkey, Halis Bayuncuk, for

25 Uslu 2007.

26 Despite its recent commitment to non-violence, Hizbullah is still considered a terrorist organization by Turkish authorities, and thus, remains under close police surveillance. The movement's publications and online websites still include many references to their original name, Hizbullah, and my interviewees from the Mustazaf-Der did not deny their link with the Hizbullah movement. Based on field observations, my impression was that the movement activists formally deny the link but informally revived the reputation of the original name, Hizbullah.

27 In Batman, the birthplace of Hizbullah, HÜDA-PAR bought off electorates from both proIslamic AKP and pro-Kurdish BDP, receiving 7.8\% in total votes. Similarly, in Bingöl and Bitlis, major provinces in Eastern Anatolia, HÜDA-PAR challenged its rivals remarkably. For an analysis of HÜDA-PAR's electoral strength, see Balcı and Efe 2014: 20-21.

28 Author's interview with Aydın Gök, the party's mayor candidate for the city, Batman, June 1, 2013 . 
example, is an ethnic Kurd whose father is serving a life sentence for being among the leaders of Hizbullah. He left Hizbullah to join al-Qaeda in Turkey, and later, the Islamic State. As the Syrian war escalated across Turkish borders, a large number of Kurds joined not only PKK-affiliate YPG but also the Islamic State - two groups that were actively fighting against each other. According to one estimate, fifty per cent of Daesh (ISIL) Turkish fighters are ethnically Kurds. ${ }^{29}$

\section{The Gülen/Hizmet Movement}

The development of the Gülen movement, also known as Hizmet movement, in Kurdish-populated cities goes back to the late 1980s. The movement's activists are gathered around ideas of Fethullah Gülen (b. 1941), a preacher, writer, and poet..$^{\circ}$ The Gülen movement emerged in the late 1970 s as a branch of the Nur movement whose leader, Said Nursi (1876-196o), was Kurdish in origin. Nursi was an ardent critic of the aggressive secularism in the formative years of the Turkish Republic..$^{31}$ Following the steps of Nursi - who suggested establishing schools to fight against ignorance in the Islamic world - Fethullah Gülen has led a mass education movement in every corner of Turkey. ${ }^{32}$

The Gülen movement consists of autonomous units including associations of workers and businessmen, private schools, and media outlets such as Samanyolu TV, Burç FM, and Zaman daily. The movement established cultural organizations, lobby groups, college student bodies, and hundreds of educational centers in 160 countries around the globe. ${ }^{33}$ Gülen activists

29 Tezcür and Çiftçi 2014.

30 The literature on the Gülen movement grows fast. For most comprehensive studies, see Turam 2007; Ebaugh 2010; Yavuz 2012; Hendrick 2013; Tittensor 2014. For comprehensive interviews with Fethullah Gülen in English, see Saritoprak and Unal 2005; Sevindi 2008.

31 Most of Nursi's students were Turkish, not Kurdish. The secularist establishment severely punished Nursi and his followers during the one-party rule (1923-1950) due to their alleged activism against the regime. Yet, Nursi's books, Risale-i Nur Collection, which focus on essentials of Islamic belief and are non-political in nature, increasingly became popular in the country. Nursi's magnum opus, the Risale-i Nur, was an attempt to combine modern sciences and the traditional Islamic beliefs and values. See AbuRabi 2003, 2008. The Nur community's openness to modernity and its commitment to non-violence have resonated with Sufi interpretation of Islam in Anatolia. See Akbulut-Kuru and Kuru 2008; Şahin 2011.

$3^{2}$ In his writings, Gülen calls his project "the golden generation" or "generations of hope." See Gülen 2004: 128-36.

33 After the demise of the Soviet Union in 1991, the movement began to open hundreds of private high schools in newly established Turkic countries in Central Asia. In the past decade, 
have long tried to form a common ground to bring members of academia, the business elite, popular artists, and opinion leaders - including minority representatives such as Orthodox Christian bishops and Alevi leaders under the umbrella of some fashionable causes such as dialogue, tolerance, democracy, and civic liberties in Turkey. ${ }^{34}$

The first Hizmet institutions were university exam prep centers (dershane) in Diyarbakır and Urfa in 1988. Hizmet's educational initiatives were financed by local businessmen who developed friendship ties through weekly tea conversations (sohbet). Conducting rare research on the Gülen movement in the city of Mardin, Mehmet Kalyoncu explains how these sohbet meetings were crucial in recruiting from the local Kurdish population:

Between 1988 and 1991, periodic sohbet meetings served as vehicles of outreach. These meetings took place in the participants' houses on a rotating basis, and through them more people were brought to understand the necessity of doing something to combat deprivations in the city, especially in the field of education. Most of them agreed that the state was unable to provide the necessary education services not only in Mardin but in all of southeastern Turkey. In fact, some of them even thought that the ultra-secular state deliberately deprived the region of schools and other basic services to punish the region's Kurdish population..$^{35}$

In addition to prep centers, Hizmet volunteers established private high schools in the early 1990s. The main curriculum and the philosophy of these schools were following the path of earlier Hizmet schools in western Turkey such as Yamanlar and Fatih..$^{6}$ These expansive projects were often followed by successful establishment of local sohbet networks, which have reached wealthier Kurdish businessmen in Istanbul for funds. The Atak high school in Mardin, for example, was the product of a few visits by a local Mardinian businessman to Dr. Vahid Atak, owner of a private hospital and several shoe factories in Istanbul. ${ }^{37}$ In early years, most teachers at Hizmet education facilities were ethnically Turkish but, as Kurdish volunteers of

the movement has expanded its project to include countries in Africa, Europe, and the Far East. For studies on Gülen schools, see Agai 2002; Dohrn 2013; Tee and Shankland 2013.

34 The movement activists annually organize Abant Meetings in which prominent writers, journalists, scholars, and artists gather to discuss Turkey's social problems. See, Uğur 2013.

35 Kalyoncu 2008: 45.

36 For pedagogical aspects of Hizmet schools, see Agai 2002: 27-47.

37 Kalyoncu 2008: 61. 
Figure 2.3 At a Hizmet prep school in Batman, students check their test scores

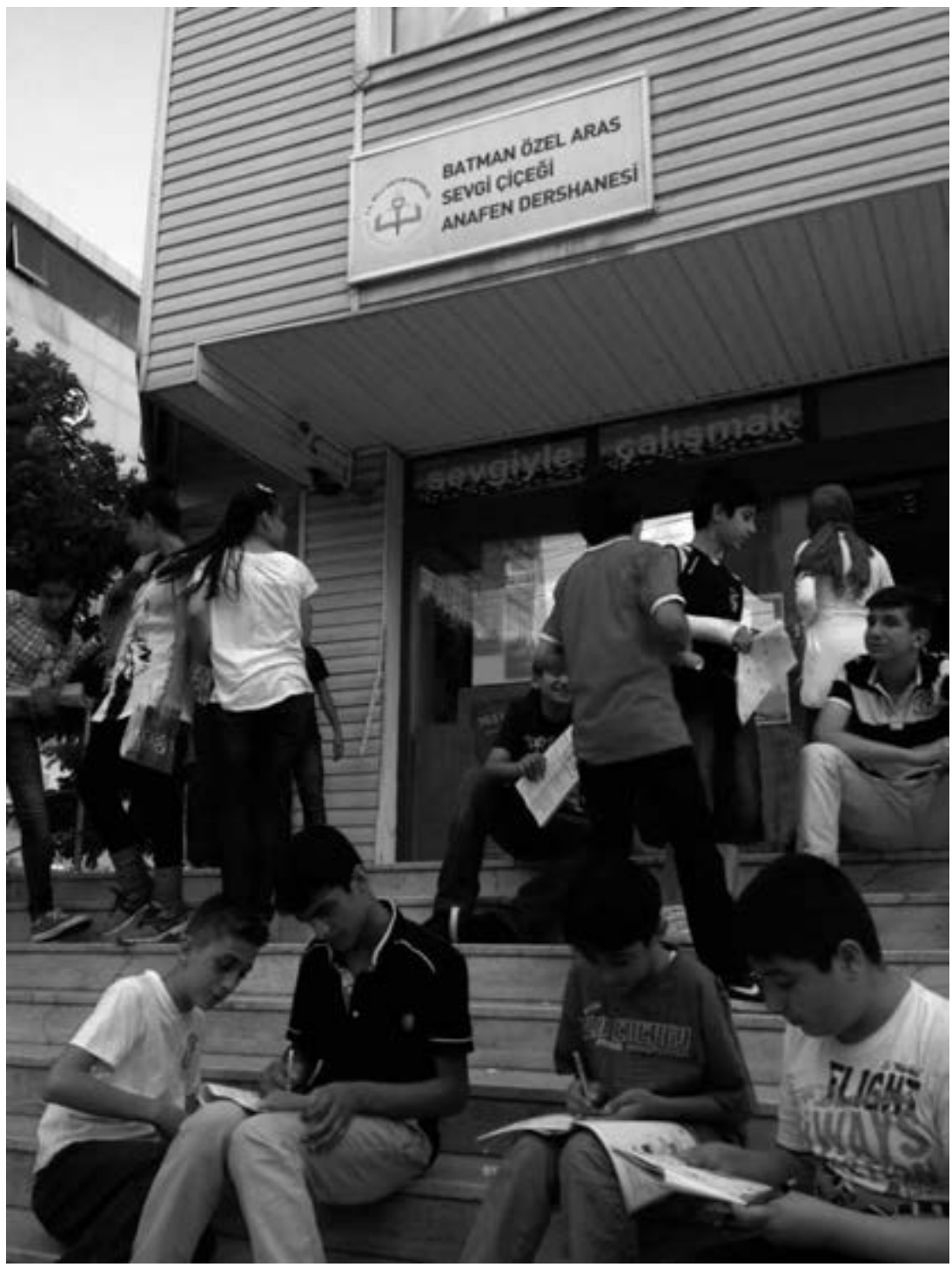

Photo by the author, June 1, 2013 
the Hizmet movement increased in numbers, Kurdish teachers replaced them..$^{8}$

The 199os witnessed a rapid proliferation of sohbet groups in every Kurdish city and town, but only after the European Union reform initiatives (2002-2004) have Gülen activists become more visible in Kurdish civil society. A decrease of PKK violence enabled them to engage in large public projects such as charity organizations, village development associations, reading halls for poor students, and women's fraternity clubs. Opening democratic channels not only helped civic association development but also strengthened Hizmet's reach to ordinary Kurds. In Nusaybin, for example, Hizmet's prep school (Sur Dershanesi) had only 15 students in 1996. The number of students increased exponentially in the 200os, reaching 280 in 2004,480 in 2005 , and 900 in 2006.39

The Gülen movement strongly supported the AKP's reformist policy against Turkish militarism until the fallout between the two groups in 2013. The movement organized two major conferences on the Kurdish issue to promote liberal and reformist perspectives, preceding the AKP government's "Kurdish Opening."40 Similarly, a few months before constitutional amendments that endorsed establishment of Kurdish-instruction private schools, Fethullah Gülen gave an interview to Rudaw to declare his support for education in the mother tongue.

Critics, however, find the movement's perspective of the Kurdish issue assimilationist. A leading expert points out that students attending Hizmet schools do not learn "Kurdish language, culture, history or politics, but

38 Kalyoncu notes that teachers' Western origin has in fact proven to be an advantage instead of being an issue of concern. The author quotes from Hayri Bey, "Most of us were quite impressed to see teachers, who were originally ethnic Turks from modern western cities like Istanbul and Izmir, coming to the underdeveloped Southeast and preparing ethnic Kurdish and Arab students for the university admissions test." Kalyoncu 2008: 48 .

39 Kalyoncu 2008: 70.

40 The conference in Erbil gathered more than 200 intellectuals from both Turkish and Kurdish origins. One of the themes of the conference focused on Turkey's long-standing fear of naming "Kurdistan." The official discourse has long resisted the usage of "Kurdistan," perceiving such naming as an existential threat to Turkey's unity. Upon criticism by some Kurdish participants, Ali Bulaç, a Zaman columnist, responded, "I am in the capital city of the Federation of the Kurdish Region in Iraq, and I'm not someone who minds stating this." The final declaration of the Abant Platform termed the region "Kurdistan Regional Government." Only a week later, Turkey's President Abdullah Gül paid a visit to Erbil and called the region "Kurdistan," becoming the first official to utter the term. Although Gül later denied using the term "Kurdistan" under heavy criticism, he added: "What shall I say? We do not refuse to say Macedonia because Greece refuses to do so." See, Demir 2012: 95. 
rather risk assimilated to a Turkish ethnic identity." ${ }^{\text {"11 }}$ For most Hizmet volunteers, educating Kurdish youth and providing civic channels for economic development are seen as panacea for the root causes of ethnic tension. Pro-Kurdish nationalist organizations find this perspective problematic, reminiscent of the Turkish State's traditional underestimation of the significance of ethnic recognition.

In recent years, Hizmet activism in Iraqi Kurdistan has become more visible, inviting competition in domestic politics. In 2014, the Kurdish regional government turned down then-Prime Minister Recep Tayyip Erdoğan's request to close Hizmet schools, pointing out that the schools offer high-quality education and the country's elite send their children to these institutions. ${ }^{42}$

\section{Locating the Pro-Islamic AKP}

Readers may wonder where the ruling Justice and Development Party (AKP) fit into the larger analysis. Similar to Kurdish nationalism, political Islam has been defined as the foremost danger for the modern Turkish Republic in the official state discourse. The secularist elite has long interpreted secularism in a radical fashion, similar to French laïcité. ${ }^{43}$

The idea that irtica, i.e. religious radicalism, threatens the foundations of the state has been inculcated from generation to generation thanks to official education and the State's overwhelming monopoly of knowledge. The Turkish Armed Forces have claimed a guardianship role to secure secularism and democracy from the so-called irtica threat. The rhetoric of irtica has legitimized serial military coups in $1960,1971,1980$, and $1997{ }^{44}$

\footnotetext{
41 Romano 2014.

42 Today's Zaman 2014. Currently there are seventeen private schools and a university, Ishik University, affiliated with the movement. Radio Dewran broadcasting in three languages (i.e. Kurdish, Arabic, and Turkish) is also run by Hizmet volunteers. For details, see Çakır 2013; Pandya 2014.

43 See, Kuru 2007, 2009.

44 Renowned historian Ernest Gellner (1997:243) succinctly depicts the issue as the following: "The basic dilemma was, so far as I could see, that the Kemalist heritage was committed to the Western sociopolitical system, but if that system was implemented, then sooner or later people who flirted with religion and betrayed the Kemalist tradition would win the elections. Either you give up democracy and in doing so contradict the principles you are supposed to be applying, or else you implement it, in which case you allow people to win who will, in turn, betray it. Under the impact of this dilemma, a new cyclical political system emerged, which for a time seemed to be institutionalized. It was quite different from the Ibn Khaldunian cycle. First,
} 
Figure 2.4 Kurdish supporters of the AKP in an election rally

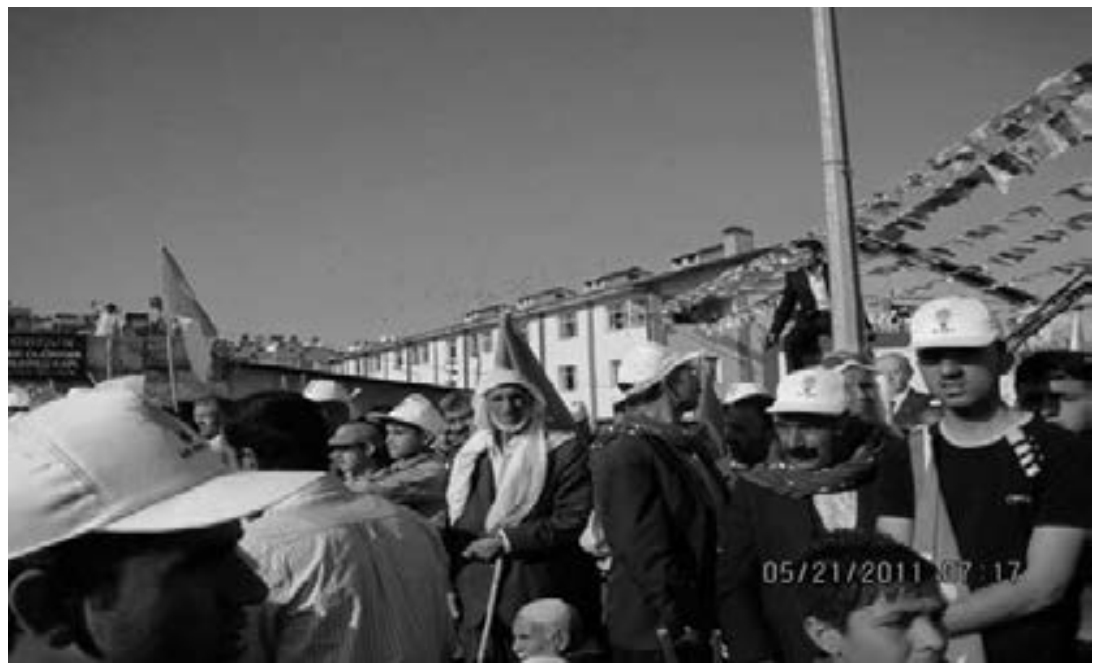

Photo by the author, Urfa, May 21, 2011

The roots of the AKP go back to the National Outlook Movement that has been, first and foremost, a political Islamic movement in Turkey. Since the 1970s, the movement's party, the National Salvation Party (MSP), received $11.8 \%$ and $8.6 \%$ of the votes in the 1973 and 1977 elections respectively and succeeded in joining in all coalition governments between 1973 and 1980.45 The 1980 military coup banned the MSP from politics as it did all other parties. After the normalization of politics in 1983, the leader Erbakan established the Welfare Party, Refah Partisi (RP), which was subsequently banned after the February 28 military intervention, known as the "postmodern coup," in 1997.

The secularist regime also banned the movement's successor party, the Virtue Party (FP) for allegedly being the center of so-called irtica, i.e.

the army, the guardian of this new democratic tradition, allows free elections to take place. A party wins that would betray the Kemalist tradition, so the army steps in and hangs its leader. Then, after a time, it hands the government back again, and so on. I think it was Mark Twain who said, 'Giving up smoking is easy, I've done it so many times.' The Turkish army could say, 'Reestablishing democracy is easy, we have done it so many times.' And so this cycle appeared as if it were institutionalized."

45 Dağ $2005:$ 24. The National Salvation Party was established after the 1971 military coup as the successor of Milli Nizam Partisi, the National Order Party, of the movement, which was founded in 1970 . 
Islamist threat. ${ }^{46}$ The closure led to a great split within the movement: those who follow the traditional Erbakan line established the Felicity Party (SP), and those who have gathered around the new young leader, Recep Tayyip Erdoğan, formed the Justice and Development Party (AKP). ${ }^{47}$ Only a year later, in 2002, the AKP won a landslide victory in the general nationwide election, rising to power.

The AKP government swiftly undertook serious reforms to redefine the Kurdish issue thanks to the EU membership process. The AKP's support for EU-induced democratization was partly due to its weak position against the secularist military establishment. It was the second major electoral victory in 2007 that actually enabled the AKP to break the monopoly of the Turkish military on defining the Kurdish issue. The party got enormous support from the Kurdish populace, who perceived the AKP as the underdog against the military - just like Kurds themselves.

The most ambitious attempt of the AKP, perhaps, was to reach PKK militants for a possible disarmament deal. The peace talks between the government and the guerillas go back to secret Oslo meetings in 2009 then popularly known as the "Oslo Process." The meetings included PKK representatives, some members of the Kurdish diaspora, and Turkish officials. Soon after the negotiations, a group of PKK fighters from the mountains entered Turkey as a "peace envoy," signaling the opportunity for a settlement. Yet the group's crossing the border was "a highly orchestrated publicity stunt" including celebrations, parades, and political speeches praising the PKK, popularly known as "the Habur Incident." 48

Under fire from the Turkish nationalist parties, the AKP government ordered the group members to be detained. Despite being later released, the majority of them faced arrest and prosecution within a year. The government started to pressure the PKK by crushing its urban activist network, Group of Communities in Kurdistan (KCK). More than 1,500 activists including many politicians were detained on charges of being members of KCK. The Oslo

46 The eminent reason for the closure was the Merve Kavakçı incident in the Turkish Parliament in 1999. For an analysis of the Kavakçı affair as a critical turning point in Turkey, see Gürbüz and Bernstein 2012.

47 The AKP has consciously presented itself as the Conservative Democracy movement and thus rejected its roots with the National Outlook movement. Therefore, the SP is still the only party representing the National Outlook.

48 Eccarius-Kelly 2011: 193. "From the perspective of the PKK," notes Vera Eccarius-Kelly, "the government's top-down Kurdish Initiative presented a direct challenge to its influence and legitimacy in the region and needed to be stopped. The arrival of the 'peace groups' allowed the PKK to reshape its image, demonstrating to Kurdish constituents a serious desire to engage in a negotiated arrangement with the government." Pp. 194-95. 
process did not last long, and both the AKP and the PKK blamed each other for the collapse in mid-2011 when the meetings were revealed to the public. The outcome was bloody. The year 2012 was recorded as the most violent year in the fighting between the Turkish State and the PKK since 1999. ${ }^{49}$

The AKP government initiated a new campaign by reaching out to the jailed PKK leader Abdullah Öcalan. Newroz (Kurdish New Year) celebrations in March 2013 marked the beginning of a new era of yet another ceasefire, often referred to as the "Solution Process" or the "Peace Process." It was unprecedented this time, however, because the Turkish government publicly declared official negotiations with the guerillas.

The AKP's increasing authoritarianism, however, led both pro-Kurdish and pro-Turkish organizations to believe that the peace process was a trick to deceive the public in order to win the critical elections in 2014 and 2015, and thus, secure the path for Erdoğan's dream of a presidential system. The pro-Kurdish party leader Selahattin Demirtaş stated that it is not realistic to expect conflict resolution with the AKP even if negotiations would be made for fifty years. AKP leaders, on the other hand, blamed the Gülen movement for sabotaging the talks and even collaborating with the PKK to weaken the government. ${ }^{50}$

For a long time, the Gülen movement was a skeptical partner of the AKP government. Soon after the peace process was publicly declared by the government, Fethullah Gülen expressed his full support. Gülen quoted the Quranic verse, "There is benefit in peace" and stated that nations might need to accept some bitter peace agreements. The uneasiness, however, remained strong in the Hizmet community. In the words of a leading activist,

Hocaefendi ["the teacher," referring to Fethullah Gülen] said "There is benefit in peace" and he never backed away from that. That, in other words, is the cornerstone of our approach. But we also have reservations. Hocaefendi believes that while peace with the PKK is a good initiative, the State should also have Plan B, C, D and even E. Because he thinks that the PKK is not that trustworthy, and that there are ill-willed powers in the region that might interfere in the process. ${ }^{51}$

49 For comparative numbers, see Tezcür 2013: 70. Understanding emotional resentment in the Turkish public at large, then-Prime Minister Erdoğan had always denied the Oslo talks, even stating that those who claimed the existence of negotiation talks between the AKP and PKK were "despicable" (şerefsiz) appealing to "mean slanders." See, Milliyet 2011.

50 Cumhuriyet 2015; TimeTurk 2014.

51 Mustafa Akyol's interview with an anonymous activist. See, Akyol 2013. 
For Hizmet members, official talks with the PKK on disarmament were fine, but negotiating Kurdish cultural rights - referred to as "essential human rights" by Fethullah Gülen - should not be on the table. They feared that such a deal would make the PKK the sole representative of Kurds and the single defender of Kurdish rights. For Hizmet activists, it was reassuring to hear the PKK's claim that violence is indispensable to be heard by the Turkish State..$^{2}$

As Daesh (ISIL) advanced in Syria and Iraq, the AKP government's negotiations with the PKK were in a deadlock. The PKK successfully mobilized its fighters, defending Syrian and Iraqi Kurds as partners of the United States and the allies. The brutal siege of Kobane, a Kurdish town in northern Syria, intensified Kurdish nationalist sentiments across the borders. President Erdoğan's Kobane policy met with mass pro-Kurdish protests, putting the PKK and Hizbullah on opposite sides once again. The PKK militants targeted HÜDA-PAR, Hizbullah's legal party, claiming that they were supporting the Islamic State with the help of the AKP government. The clashes resulted in injuries and deaths on both sides, an unprecedented development since the mid-1990s. The peace process effectively ended after a suicide bombing appearantly conducted by Daesh (ISIL) militants in the border town of Suruç in July 2015, killing thirty-two pro-Kurdish party (HDP) activists. Massive violence erupted in Kurdish towns, causing the Turkish State and the PKK to resume the conflict once again.

Despite perilous confrontations in turbulent times, a closer look at the historical trajectory of Kurdish ethno-nationalist and Islamic movements reveals a deep transformation in their relationship. The PKK and Hizbullah militants were in an armed conflict in the early 1990s. Since Turkey's European Union membership negotiations, however, these two movements have become highly active in the civic sphere - not only competing with each other but also with an ever more challenging rival, the Gülen movement. What follows is the story of a broader structural transformation in the past decade. The changing political context has paved the way for organizational competition in an emerging Kurdish civil society.

$5^{2}$ Fethullah Gülen was more explicit in his interview with BBC where he stated that Abdullah Öcalan was uneasy with the Hizmet's educational activism in the region: “They didn't want our activities to prevent young people joining the militants in the mountains. Their politics is to keep enmity between Kurdish and Turkish people." See BBC 2014. 



\section{Exogenous Shocks on the Eve of the Millennium}

On February 15, 1999, the Turkish Armed Forces captured Abdullah Öcalan, the PKK's founder and charismatic leader. Öcalan's capture led to major pro-Kurdish protests including mass hunger strikes in 147 Kurdish associations all over the world, public demonstrations, and marches to embassies in many European cities. Seventy-four people set themselves on fire to protest assaults on Öcalan, indicating how he acquired an unprecedented role in contemporary Kurdish politics. Sixteen of them burned to death.

Although suicide attacks by PKK members were not a new means of political protest, organization of self-immolation campaigns was a novel ethno-nationalist tactic. ${ }^{2}$ The majority of the self-immolation protests were conducted by pro-Kurdish political prisoners in Turkey; however, a considerable number of everyday activists also joined the campaign at this time, including an eleven-year-old Kurdish girl in Iran and a fifty-six-year-old housewife from Istanbul. ${ }^{3}$

Context matters to strategic choices. Political institutions and discursive contexts play significant roles in shaping the dynamic interaction between players and arenas. Activists interpret their environs and larger political milieu and shape their strategies accordingly. As Jack Goldstone notes, "Much of the dynamism behind social changes comes from the constant tension in social life between individual innovation and socially-imposed convention." We should not mistake, however, structural conventions as explanans of ethnic activists' behavior; instead, we need "to constantly be alert to the possibilities of innovation within and against convention, even while granting conventions and institutions their role as the baseline set of

1 Total number also includes pre-capture period when the PKK leader was on the loose. The PKK's self-immolation campaign was launched after Öcalan's interview with Med-TV on October 19, 1998, where the PKK leader condemned "great international conspiracy" against him. For the complete list of self-immolations, see Özcan 2006: 279.

2 There was also a PKK campaign of suicide attacks to protest Öcalan's capture. In a few months, seven suicide attacks occurred, leaving four people killed and seventy wounded. For detailed accounts of these attacks, see University of Chicago's Project on Security and Terrorism database, http://cpostdata.uchicago.edu/search_new.php

3 Özcan 2006: 12. 
expectations, practices, and understandings in which action is embedded." ${ }^{\prime 4}$ Social action, said Pierre Bourdieu, is "saturated with history."5

Such a relational approach would move from "causes" to "events" in reading the critical junctures in social mobilization. ${ }^{6}$ I argue that the transformation of ethnic conflict in Turkey needs to be studied as an outcome of social movement competition as well as exogenous shocks. The culture of social movement rivalry does not emerge in a vacuum.

What follows is a quick overview of the Turkish political environment during the past decade. Four critical events constituted major exogenous shocks: (a) The arrest of the PKK leader Abdullah Öcalan, (b) the initiation of the talks between Turkey and the European Union for membership prospects, (c) the war on international terror after the $9 / 11$ attacks in the US, and as a consequence, the establishment of Iraqi Kurdistan as a semiindependent state, and (d) the electoral victory of the AKP and introduction of reforms on the Kurdish issue. These exogenous shocks have dramatically shaped the context for social movement competition in the Southeast.

\section{Abdullah Öcalan: The Role of the PKK Leader in Shaping Kurdish Politics}

The arrest of the PKK leader came as a shock to Kurdish ethno-nationalists. Internal disputes among the guerilla fighters led some PKK members to quit the movement. ${ }^{7}$ The PKK was quick in declaring a ceasefire unilaterally. Nonetheless, Öcalan's appeal has continued to be strong in the PKK movement.

The ethno-nationalists have long revered Öcalan, calling him institutional terms such as Önderlik, i.e. "leadership" of the party, with an implication that he is something more than a mere human being. Conducted a year after his arrest, Ali Kemal Özcan's survey indicated that Öcalan was still perceived as the main reason for collective success. Among 185 PKK

\footnotetext{
4 Goldstone 2010: 366.

5 Bourdieu 1993: 74.

6 An event may be regarded as an "exogenous shock" (Fligstein and McAdam 2012: 206) or as "a product of the endogenous incoherence of an aggregation or assemblage of multiple orders" (Clemens 2007:542). In any case, the focus on events is useful in understanding ethnic conflict transformation because it rests on an increasing consensus among historical sociologists to consider "episodes rather than systems" (Clemens 2007:542) as the primary unit of analysis. On "causes" and "events" from a theoretical perspective, see Sewell 1992; Abbott 2001.

7 For details, see Marcus 2007: 288.
} 
Figure 3.1 Image of the PKK's jailed leader Abdullah Öcalan at a public rally

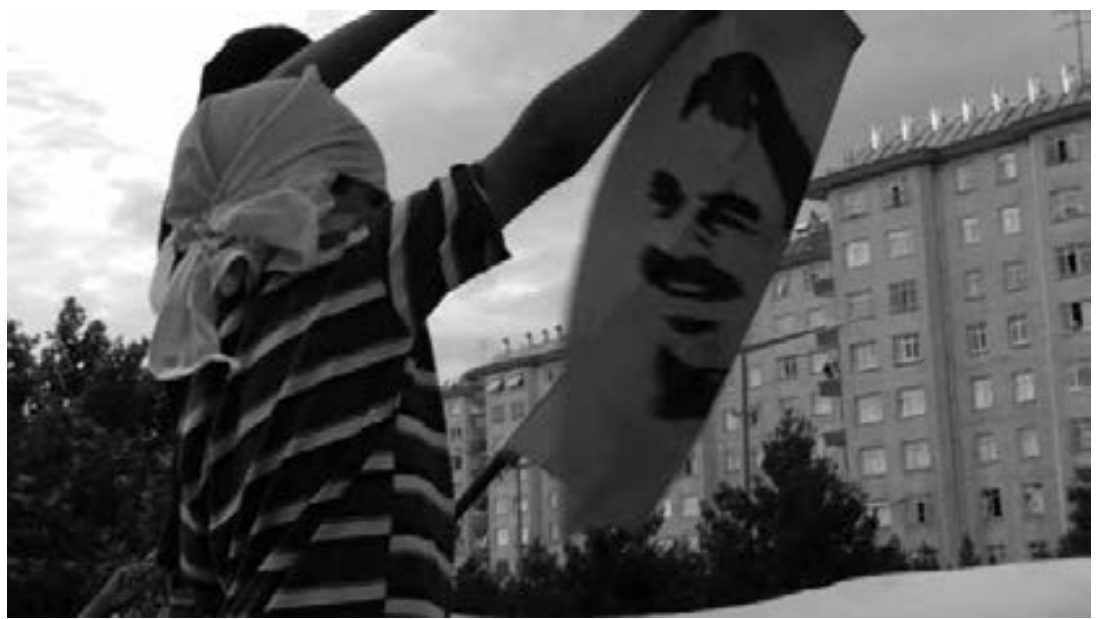

Photo by the author, Diyarbakır, July 15, 2009

members who were asked what the most fundamental cause of the PKK's success was, ninety-three responded "the leader."

The charismatic quality of Abdullah Öcalan convinced the Turkish state authorities to benefit from his influence instead of applying a capital punishment. ${ }^{9}$ High military officials including representatives of the chief of the General Staff visited him in Imralı Prison, which was established solely for Öcalan on a small island (Island of Imralı) in the Marmara Sea. The interrogation process was actually a negotiation. The PKK leader persuaded the authorities that he could be useful in communicating with the guerillas in the mountains. For Öcalan, the aim of the PKK would not be to form an independent Kurdistan; instead, a "democratic Republic" that recognizes Kurdish cultural rights would be a path to pursue in satisfying the PKK rebels. He called this vision "democratic Republic thesis." After internal discussion within the Turkish state apparatus, the officials asked if he could convince the PKK fighters to believe in his new vision despite the fact that he was captured. "They will be with me," Öcalan answered without hesitating. ${ }^{10}$

8 Other responses include ideology (19.5\%), discipline (10.3\%), armed struggle (7.6\%), and lifestyle (4.3\%). See, Özcan 2006: 263 .

9 Marcus 2007: 283.

10 Kapmaz 2011: 18-20. 
Öcalan's remaining influence paved the way for stronger - but non-violent - pro-Kurdish activism in the political realm. By encouraging legal political activism, Öcalan developed direct channels with the pro-Kurdish party officials. He has also continued to be the idol of the revolutionary cause for the PKK guerilla fighters. Thus, as the pro-Kurdish party has successfully advanced and gained Kurdish votes in the past decade, Öcalan's "arbiter" role in the larger pro-Kurdish movement has been deeply engrained.

Öcalan articulated the "democratic Republic thesis" in his prison writings. Öcalan's talks from his cell were regularly recorded by his lawyers and widely shared among the Kurdish constituency, popularly called Görüşme Notlar, i.e. the Meeting Notes. Expecting strategic outcomes, the Turkish authorities have allowed Öcalan to communicate in various ways that could reach the Kurdish grassroots. ${ }^{11}$ Öcalan's thesis of "democratic Republic" was crystallized after the pro-Islamic AKP came to power in 2002. The Turkish military was highly concerned about the AKP's Islamic roots, and Öcalan played the secularism card to get the sympathy of the secularist elite. In the sections to follow, I examine the rapid transformation in the Kurdish ethnonationalist discourse as well as its repercussions within the movement.

\section{Seeking Alliance with the Turkish Secularist Elite}

As a movement that has deep Marxist roots, the PKK never capitalized on its secularist identity to find common ground with the Turkish State until the AKP came to power and started to implement pro-Kurdish reforms (2002-2004). Led by Abdullah Öcalan, the PKK has revisited its stance against the official secularist ideology - known as Kemalism due to its roots in the thought of Mustafa Kemal Atatürk, the founder of the modern Turkish Republic. In the traditional PKK discourse, Atatürk (which literally means "the father of Turks") was an "opportunist" tyrant, and the Kemalist ideology was the basis of "proto-fascist dictatorship" and "wild, Hitlerian, and fascist administration., ${ }^{12}$ With Öcalan's suggestion of the "democratic Republic," however, Mustafa Kemal Atatürk is radically reinterpreted.

In his recent writings, Öcalan consistently refers to him as Mustafa Kemal instead of Atatürk, i.e. "Father of Turks," which holds negative connotations for Kurds. Öcalan praised Mustafa Kemal Atatürk for his vision of a democratic Republic very early on:

11 The PKK-affiliated online platforms such as http://www.rojaciwan.com/ and http://www. firatnews.com/ provide the Meeting Notes in full version. Öcalan fully articulated the democratic Republic thesis in his books. See Öcalan 2003, 2007.

12 Öcalan 1999. 
Mustafa Kemal had his own way of seeking independence because he regarded both republicanism and democracy as essential ... Mustafa Kemal was Robespierrian. Robespierre was a democratic republican who tried to establish the (French) Republic. Robespierre was a Jacobin and a French bourgeoisie democrat ... Similarly to Robespierre, Mustafa Kemal was trying to establish and defend the Republic; yet, he was surrounded by his personnel who were linked to the British. These people, after making him ineffective, created a political theology that killed Mustafa Kemal's spirit about the year 1924 ... Indeed, both Mustafa Kemal and Robespierre were working to found a democratic republic. Mustafa Kemal was not allowed to give life to his republican views. ${ }^{13}$

By portraying Mustafa Kemal as Robespierrian, Öcalan salutes the Turkish secularist elite. Defending the French model of secularism, laïcité, Turkey's Kemalists are presenting themselves as especially sympathetic to French revolutionaries.

Öcalan's effort to reinterpret Mustafa Kemal was supported by proKurdish party officials' frequent secularist statements. For instance, prominent DTP deputy Hasip Kaplan declared:

Everyone should know the following very well: In the case of our absence, Sharia (Islamic Law) would dominate in the Southeast. We are those who are the real guardians of laicism! Our discourse of secularism is in tandem with the secularist discourse of the Turkish Armed Forces. In terms of laicism, the DTP plays a role of guarantor in East and Southeast Turkey. If the DTP is closed or it becomes inactivate, religious radicalism would spread in the region. ${ }^{14}$

The PKK commander Murat Karayılan agreed: "Although overthrowing the PKK is impossible, let's say the PKK was defeated and finished. Do you know what happens to the region? The Southeast becomes the center of religious radicalism." Karayllan singled out two groups as evidence of radical religious tendencies: Hizbullah and the Gülen movement. ${ }^{15}$ The PKK's strategic secular identity deployment aimed to build legitimacy in the eyes of the Turkish secular bureaucratic elite who have strong concerns 
about the pro-Islamic party in power (AKP) and other Islamic movements, primarily the Gülen movement and Hizbullah.

\section{Building Legitimacy in the Broader Public}

The PKK's changing discourse drew criticism from Kurdish ethno-nationalists. Some PKK members accused Abdullah Öcalan of selling out to the state elite in order to save himself. ${ }^{16}$ Some critics have left the movement and formed alternative online platforms such as Nasname and Kurdistan Aktüel. ${ }^{17}$ In these virtual platforms, one could find intellectual criticisms of the PKK and its leader Abdullah Öcalan from various Marxist and socialist perspectives. Interviews with İsmail Beşikçi and other independent radical leftists are frequently featured. Authors strongly criticize the PKK's renunciation of independent Kurdistan. ${ }^{18}$

In May 2004, Osman Öcalan, the brother of the PKK leader, and a group of high-ranking commanders left the PKK and formed an organization called Partiya Welatparêzên Demokrat (PWD). The PWD harshly criticized the PKK's blind submission to its captive leader and the authoritarian culture within the movement. ${ }^{19}$ The split within the movement, however, was not devastating. The PKK and the Kurdish political parties united strongly around the leadership of Abdullah Öcalan. In order to save its organizational strength and reputation, the PKK reemployed arms against the Turkish State in June 2004. At the same time, the PKK remained faithful to Öcalan's "democratic Republic" discourse, signaling that a separate Kurdish state may not be the ultimate goal if the Turkish State is open to negotiations.

The growing success of pro-Kurdish political parties in local elections helped to sustain the two-fold strategy of the ethno-nationalist movement:

16 Marcus 2007: 286-91.

17 See www.nasname.com and www.kurdistan-aktuel.org. These online platforms publish articles in both Turkish and Kurdish.

18 See, for example, Demircan 2009. For an analysis of Beşikçi's remarkable works, see Van Bruinessen 2005. İsmail Beşikçi's views on self-determination and an independent Kurdish state are widely circulated as well as his criticism of the PKK leader. "Abdullah Öcalan," remarks Beşikçi, "recently said that 'I am a free individual, and therefore, I oppose the nature of the state as an institution since the state as a construct is a means of oppression.' He also says that 'I have nothing to do establishing a state' ... Although Öcalan often repeats his opposition to the state as an institution; he never had a word against a real, materialized state that oppresses Kurds each moment every single day ... It seems that Öcalan has no problem with the Turkish, Arab, and Iranian states. He only does not want Kurds having their own state, which is the very policy of Turkey, Iran, Iraq, and Syria." See, http://www.nasname.com/tr/4638.html, Accessed April 9, 2011.

19 Tezcür 201ob: 781. 
on the one hand, the PKK employed arms against the authorities; on the other hand, pro-Kurdish political parties have increasingly become involved in non-violent civil society activism, further penetrating to the Kurdish grassroots. Gradually gaining control of many municipalities in Kurdish provinces and towns, Kurdish ethno-nationalists mobilized more resources and formed an imaginary "as-if Kurdistan." ${ }^{20}$

\section{The EU Factor: Turkey's Membership Process and De- Securitization}

Turkey's recognition as a candidate country for the European Union at the Helsinki summit in December 1999 ushered in a new era of TurkishEuropean relations. The Helsinki decision gave Turkey a serious prospect for the first time. Earlier, the EU's previous welcoming of Eastern European countries and its apparent reluctant approach to Turkey's long-standing bid alienated many Turks who support the westward orientation of the country. Many believed that Europe is an ethno-religious club that will never accept a predominantly Muslim country. Although the Helsinki summit did not confer any special right to Turkey, it gave the most serious hope for full membership. Accordingly, Turkey has undertaken significant reforms to harmonize its policies to meet the EU criteria. ${ }^{21}$

The EU membership process led to a paradigm shift in public discourses on the Kurdish issue. One of the essential measures for joining the EU was the protection of minority rights, specifically in reference to Kurds in the country. According to the Turkish official view, however, Kurds were not a minority in Turkey; instead, all ethnic groups including Kurds are entitled to the same rights based on Turkish citizenship. The EU process empowered pro-Kurdish voices to challenge the State and provided both political and discursive opportunities for changes in institutional practices. Between 2001 and 2004, several EU harmonization packages were introduced, gradually diminishing the Turkish military's monopoly in defining the Kurdish issue. ${ }^{22}$

Table 3.1 presents constitutional and legislative changes regarding Kurdish cultural rights in Turkey. In October 2001, the Turkish Parliament accepted the first constitutional change package that amended thirtyfour articles including the third paragraph of Article 26, which asserted 
Table 3.1 Constitutional and legislative reforms regarding Kurdish cultural rights

\begin{tabular}{|c|c|c|c|}
\hline Type & Title & Date & Reform \\
\hline Constitutional & & October 2001 & $\begin{array}{l}\text { The ban on using languages } \\
\text { and dialects (other than Turk- } \\
\text { ish) in disseminating thoughts } \\
\text { (in daily life) was removed }\end{array}$ \\
\hline Constitutional & & October 2001 & $\begin{array}{l}\text { The statement that "publica- } \\
\text { tion shall not be made in any } \\
\text { language prohibited by law" } \\
\text { was removed }\end{array}$ \\
\hline Legislative & $\begin{array}{l}2^{\text {nd }} \text { Harmonizing } \\
\text { Package }\end{array}$ & March 2002 & $\begin{array}{l}\text { Restrictions on the use of } \\
\text { Kurdish in the press were } \\
\text { removed }\end{array}$ \\
\hline Legislative & $\begin{array}{l}3^{\text {rd }} \text { Harmonizing } \\
\text { Package }\end{array}$ & August 2002 & $\begin{array}{l}\text { Radio and television broad- } \\
\text { casts (public and private) in } \\
\text { Kurdish were legalized and } \\
\text { the establishment of Kurdish } \\
\text { private language courses was } \\
\text { allowed }\end{array}$ \\
\hline Legislative & $\begin{array}{l}4^{\text {th }} \text { Harmonizing } \\
\text { Package }\end{array}$ & January 2003 & $\begin{array}{l}\text { Associations can use } \\
\text { foreign languages (including } \\
\text { Kurdish) in their non-official } \\
\text { correspondence }\end{array}$ \\
\hline Legislative & $\begin{array}{l}6^{\text {th }} \text { Harmonizing } \\
\text { Package }\end{array}$ & June 2003 & $\begin{array}{l}\text { The Civil Registry Law was } \\
\text { amended to permit parents } \\
\text { to name their children as } \\
\text { they desire (including Kurdish } \\
\text { names) }\end{array}$ \\
\hline
\end{tabular}

Adapted from Sarigil 2007: 184-85

that "no language prohibited by law shall be used in the expression and dissemination of thought," and the second paragraph of Article 28, which stated that "publication shall not be made in any language prohibited by law" were abolished. ${ }^{23}$

The constitutional changes were followed by several "harmonizing packages" in order to adopt new laws, bylaws, and administrative ordinances in line with the European Union requirements. Thus, the ban on the use of Kurdish in speech, publication, and broadcasting ended. ${ }^{24}$ In addition

23 Sarigil 2007: 184.

24 These initial reforms, however, were restrictive. For example, private TV and radio stations were not allowed to broadcast in Kurdish as late as December 2005; and also, these private channels were allowed only forty-five minutes a day of Kurdish broadcasting. These restrictions 
Figure 3.2 OHAL, Emergency Rule Law, region (1987-2002). The provinces that were highly securitized are colored dark.

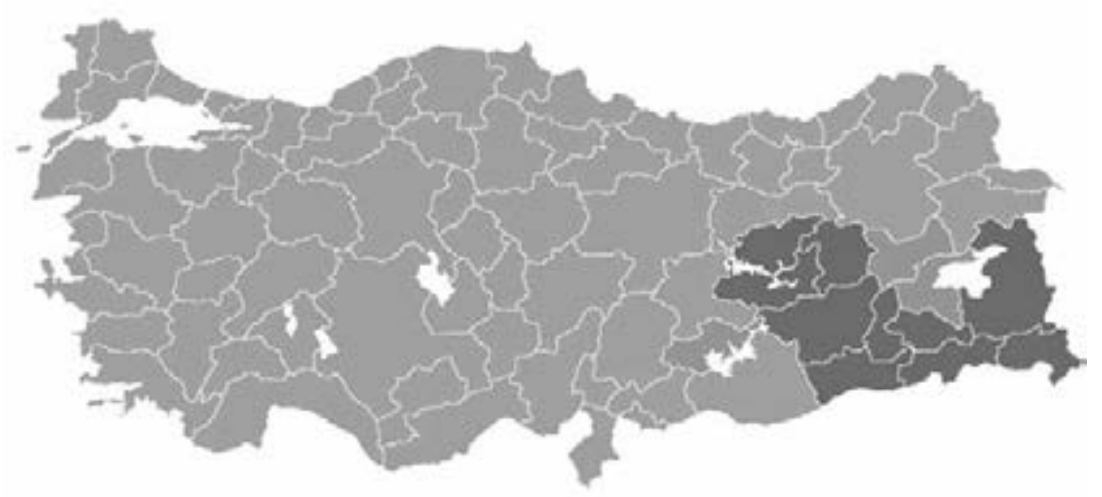

to reforms in cultural rights, the EU membership reforms included the abolition of the state security courts, reforms to ensure civilian control over the National Security Council, the abolition of the death penalty, and most importantly, the eradication of the Emergency Rule Law in the Southeast. ${ }^{25}$

The lifting of the Emergency Rule Law deserves particular attention in order to grasp recent changes in Kurdish politics. After the military coup in 1980, majority of Kurdish cities were governed under martial law. The martial law was lifted in July 1987; however, soon after, the Turkish State authorities declared Olağanüstü Hal (OHAL), Emergency Rule Law, as a reaction to the rise of the PKK. At its peak in the mid-199os, OHAL was in effect in thirteen provinces (Figure 3.2).

Thus, not officially but practically, Kurdish-populated provinces were separated from other provinces in Turkey. Granted extraordinary powers, a regional governor ruled the entire OHAL region from his post in Diyarbakır. The governor could (a) evacuate and resettle civilian areas in the interests of the region's security, (b) detain suspects without charge for up to ten days, (c) prohibit publications deemed to be provocative, (d) empower security authorities to search homes and party offices without a warrant, and (e) restrict public meetings. ${ }^{26}$ Despite being lifted in some provinces in the late 
1990s, the OHAL regime remained in effect in Southeastern provinces of Diyarbakır, Şırnak, Hakkari, and Tunceli until 2002.

The total eradication of the OHAL ushered in a new era in the Southeast in which "autocratic militarism" had been in effect for more than two decades. De-securitization has opened up new civil spaces wherein various social movements operate and through which diverse cultural reflections of Kurdish-ness could emerge, especially in urban centers such as Diyarbakır. Examples of emerging cultural spaces for expressing Kurdish identity include dengbêj (traditional male singers reciting Kurdish poems) performances, newroz (Kurdish new year) celebrations, Kurdish film festivals, fine art houses, youth centers, women's fraternity clubs, and Kurdish language schools.

\section{Changing International Political Environment}

The EU-led reforms coincided with a major change in the international context - the 9/11 attacks and subsequent invasion of Iraq by American forces. In the post-September 11 world, PKK guerillas felt vulnerable due to increasing cooperation between the US and Turkey on international terrorism. The PKK rebels' claim to be Kurdish freedom fighters fell on deaf ears as Western nations increasingly became less tolerant of armed struggle which is widely denounced as 'terrorism.'

Grasping the new reality, the PKK adopted a new organizational name, KADEK, in April 2002. Yet, the KADEK was also listed as a terrorist organization soon after its formation. As a result, the Kurdish ethno-nationalists decided to dissolve the KADEK in order to establish a broader platform that would emphasize civil society activism in urban spaces. In their press release, KADEK leaders stated:

The substantial democratic openings expressed in the organization's program were only inadequately reflected in its inner structure; the personal continuity in the upper echelons fueled spitefully dismissive notions that the KADEK was a mere continuation of the PKK. This, in turn, tainted international overtures and negatively affected the democratization process envisaged ... It is on these grounds that the Congress for Democracy and Freedom in Kurdistan (KADEK) is being dissolved in order to make way for a new, more democratic organizational structure that allows for broader participation. This new structure shall be representative of the Kurdish people's interests, legitimate under international 
criteria, and conducive to the pursuit of democratic and lawful political articulation with a view to negotiating a peaceful settlement with the dominant nation states. ${ }^{27}$

The final outcome was the formation of Kongra-Gel, the People's Democracy Congress, in November 2003.

The PKK's aforementioned strategies to employ a democracy/humanrights centered discourse enabled non-violent elements in the pro-Kurdish movement to increasingly gain power at the expense of the armed wing. An unprecedented contention occurred on the eve of the local elections in 2004, when the PKK leadership and the pro-Kurdish DEHAP party leadership had a dispute over the candidacy of the outgoing pro-Kurdish mayor of Diyarbakır, Feridun Çelik, who maintained that he would run as an independent against the wishes of the party. ${ }^{28}$ Although the PKK leadership initially supported Feridun Çelik, DEHAP's administration chose a human rights activist, Osman Baydemir, as its candidate, and soon after, Çelik withdrew his candidacy. ${ }^{29}$

Another significant global factor that shaped the PKK's policies was the formation of the Kurdish Regional Government (KRG) in northern Iraq due to the American invasion of Iraq and subsequent support by the US authorities. The KRG has operated as a "quasi-state" in the region and pursued a strategy of cooperation with regional governments in the Middle East in order to assure "external patronage, international recognition, and open borders" instead of defending pan-Kurdish nationalism..$^{30}$ Thus, under pressure from regional states as well as Iraqi authorities in Baghdad, the KRG took severe measures by closing PKK-affiliated offices in the cities, blockading routes to the Qandil Mountains where the PKK is based, and adopting a public position against $\mathrm{PKK}$ activities.

Considering the fact that Northern Iraq had been a strategic landscape to house PKK fighters, these developments were worrisome for the PKK leadership. At the same time, having a relatively independent new Kurdish homeland in Iraq has strengthened pro-Kurdish party activism through reinforcing the Kurdish ethno-nationalist imagination in Turkey: Iraqi Kurdish artists, musicians, and intellectuals are often invited to organize 
fairs, art exhibitions, workshops, and panel discussions. ${ }^{31}$ In essence, on the one hand, the formation of a Kurdish quasi-state introduced further challenges to PKK guerillas fighting against the Turkish State while on the other hand, it had a positive impact on pro-Kurdish political activism. The transnational context, thus, has strongly favored the Kurdish ethnonationalist movement's non-violent elements.

\section{The Rise of the AKP: Radical Shifts in Turkish Politics}

One of the major factors that enabled the EU membership reforms was the increasing success of the pro-Islamic party, the AKP. After coming to power in the general elections of 2002, the AKP tried to consolidate its position against the Turkish secularist military elite who regarded Islamism as the most dangerous enemy against the state regime. As a party that has roots in political Islamism, the AKP government was met with concerns in domestic and international contexts. The AKP needed to show its "sincerity" about pro-western democracy to gain political legitimacy, primarily from the USA and European powers. Therefore, the European Union reform packages were a golden chance for the AKP government. The AKP strongly supported the democratization reforms, which weakened the secularist military elite and provided international support for its rule.

As presented earlier (Table 3.1), almost all key pro-Kurdish reforms took place between the years 2002 and 2004 when the AKP government was in power. The AKP's policies paid off well in the general elections in 2007 (Figures 3.3 and 3.4). The pro-Islamic party outperformed the pro-Kurdish DTP in Kurdish-populated provinces, winning about $44 \%$ of the total vote versus the DTP's $38 \%$.

As Figure 3.3 and Figure 3.4 indicate, while the AKP has dramatically increased its vote in every single Kurdish province, the pro-Kurdish party (DEHAP in 2002, DTP in 2007) has lost votes in many provinces including key provinces such as Diyarbakır and Van. ${ }^{32}$

Thus, the AKP's Islamic discourse, with its commitment to the EU democratization process, appeared to resonate with the Kurdish public - a

31 Watts 2010: 173 .

32 Data on elections in Turkey between 1954 and 2007 is available at www.belgenet.net. In the Tables, 2002 election results in Siirt province reflect the first election, which was cancelled later. Since the pro-Kurdish DEHAP party did not participate in the second election in 2003, I consider that the first election would provide a way to compare the AKP and the pro-Kurdish parties. 
Figure 3.3 The AKP's comparative performance in Kurdish provinces (the general elections of 2002 and 2007)

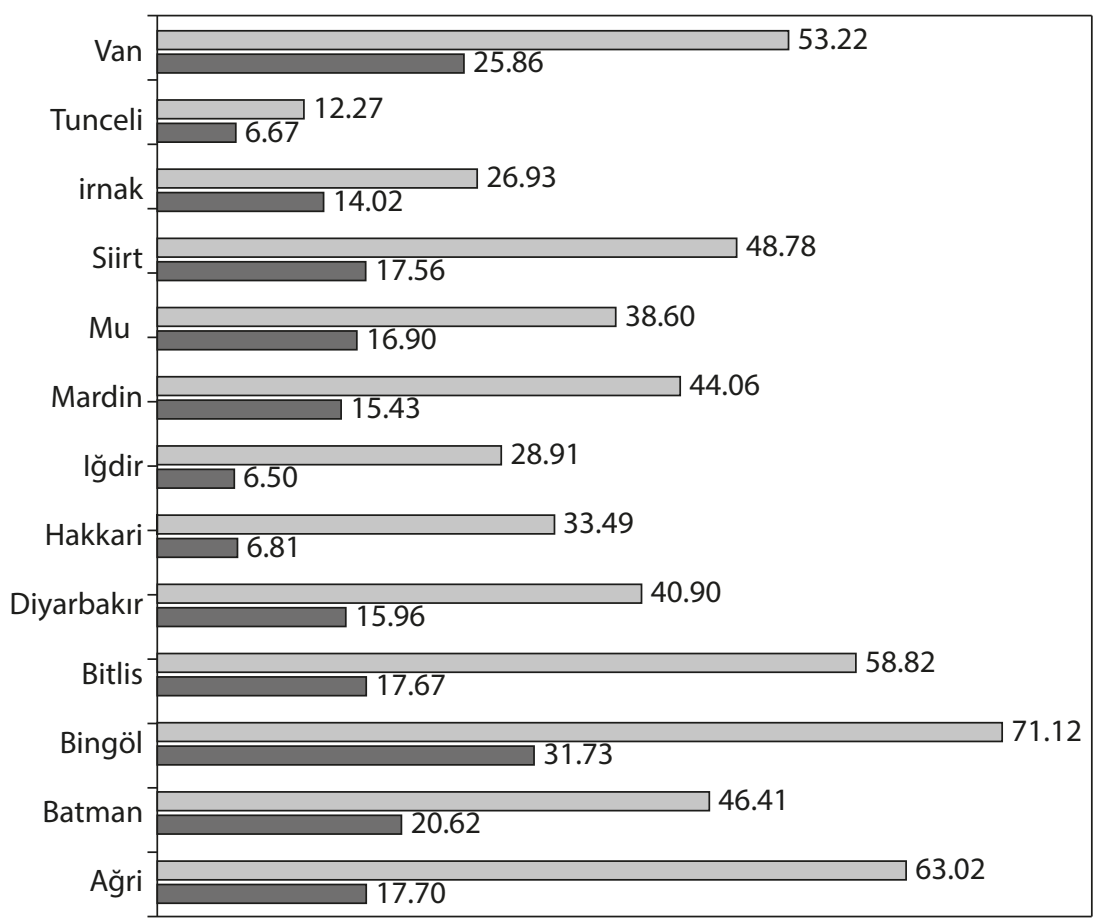

DAKP $2007 \square$ AKP 2002

predominantly religious polity. The 2007 election defeat has become a turning point for Kurdish ethno-nationalists in transforming their traditionally bitter relations with the local culture of Kurds. They have gradually become strong actors in defining "Kurdish Islam."

Moreover, as described in the previous chapter, the Gülen/Hizmet activists have become highly visible in the Kurdish public sphere and have gained influence with the grassroots, especially after the pro-Kurdish reform period (2002-2004). Since the Gülen movement does not have its own political party, its grassroots influence among Kurds was translated into pro-AKP votes. Given the fact that both the AKP and Hizmet have Turkish-Islamic roots, the Kurdish ethno-nationalists perceived them as one joint camp that works against their movement. ${ }^{33}$ This perception was widely shared 
Figure 3.4 The pro-Kurdish party's comparative performance in Kurdish provinces (the general elections of 2002 and 2007)

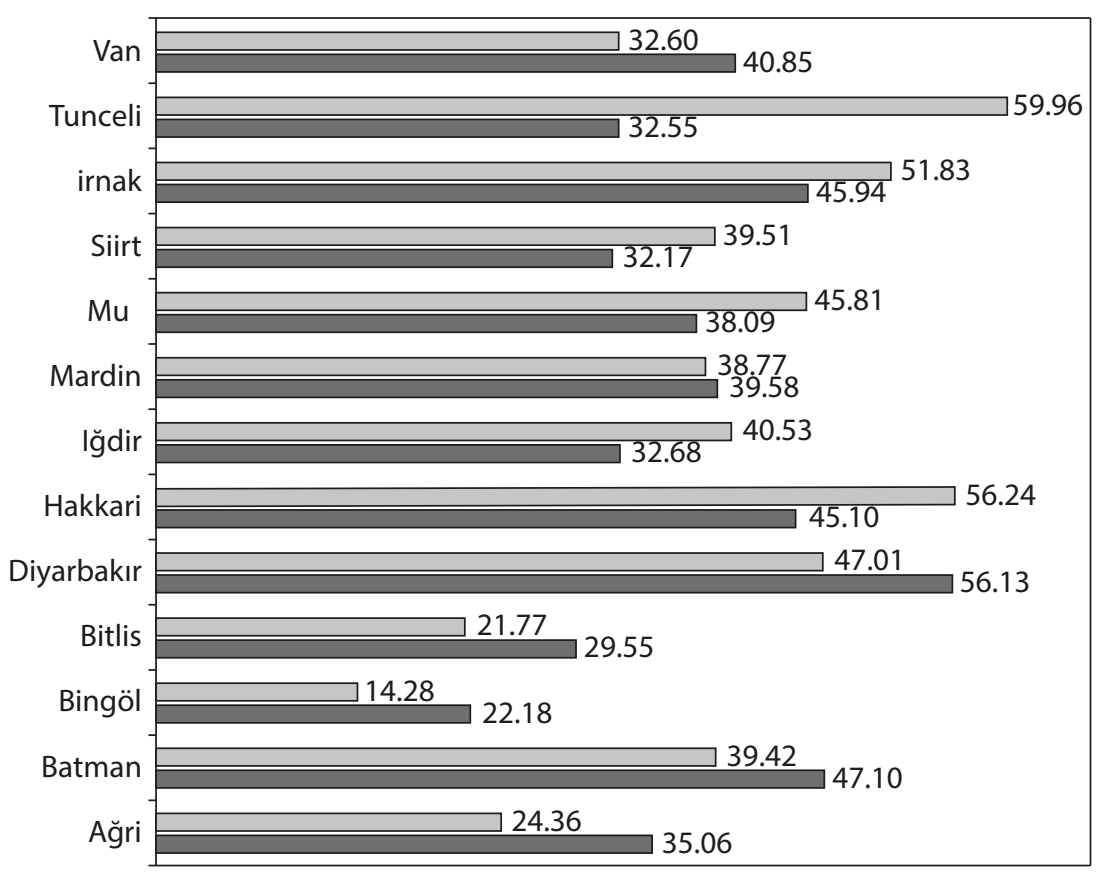

$\square$ DEHAP/DTP 2002 口 DEHAP/DTP 2007

until the AKP government declared open war against Hizmet after the corruption scandal in December 2013. The ethno-nationalists claimed that the AKP and the Gülen movement are puppets of American imperialism to transform the Middle East. For the PKK commander Murat Karayılan,

Fethullahists [i.e. Fethullah Gülen movement supporters] are trying to settle into the state hierarchy; this is why they have become close to the Justice and Development Party (AKP). They have gained power. They are getting support from the United States as well. The USA puts forth the Fethullahists to the Muslim World ... They say 'We are also against the PKK; we're also pro-state,' and therefore, they infiltrate the state ... They're (widespread) among the AKP supporters. ${ }^{34}$ 
In the same interview, Karayllan accuses Hizbullah of being co-opted by Iran and working to eliminate the pro-Kurdish movement.

The next chapter provides a closer look at the changing dynamics at the local grassroots level and describes how these rival movements have engaged in civil society activism.

Table 3.2 Historical timeline of the social movement competition process (analyzed in the forthcoming chapters)

\begin{tabular}{|c|c|}
\hline Years & \\
\hline 1978 & The establishment of the Kurdistan Workers' Party, PKK \\
\hline 1979 & The establishment of Hizbullah \\
\hline 1980 & The military coup d'état and the implementation of martial law \\
\hline 1984 & The beginning of PKK attacks on Turkish authorities \\
\hline 1987 & Institutionalization of the Emergency Rule Law (OHAL) \\
\hline 1988 & The establishment of private Hizmet prep schools in the region \\
\hline 1991-1996 & Years of bloody conflict between the PKK and Hizbullah \\
\hline 1996 & The establishment of private Hizmet high schools in Diyarbakır \\
\hline 1999 & The capture of Abdullah Öcalan, the PKK leader \\
\hline 1999 & Start of Turkey's EU negotiation talks \\
\hline 2000 & $\begin{array}{l}\text { Police operation against Hizbullah and killing of Hüseyin Velioğlu, the } \\
\text { Hizbullah leader }\end{array}$ \\
\hline 2002-2004 & Democratic reforms passed by the pro-Islamic AKP \\
\hline 2004 & Beginning of the Gülen movement's charity organization activities \\
\hline 2004 & The establishment of Mustazaf-Der, Hizbullah's charity organization \\
\hline 2004 & Public circulation of written publications of Hizbullah for the first time \\
\hline 2005 & $\begin{array}{l}\text { Hizmet activists' opening of reading center chains for poor students in } \\
\text { slums }\end{array}$ \\
\hline 2006 & $\begin{array}{l}\text { The mass public demonstration to protest 'the Danish cartoons' organized } \\
\text { by Hizbullah }\end{array}$ \\
\hline 2006 & $\begin{array}{l}\text { The establishment of Sarmaşık, the Kurdish ethno-nationalist charity } \\
\text { organization }\end{array}$ \\
\hline 2007 & The ethno-nationalists' founding of DIAYDER, Kurdish Imams' Association \\
\hline 2007 & The electoral victory of the pro-Islamic AKP \\
\hline 2008 & Women's Honor Campaign, organized by ethno-nationalists \\
\hline 2008 & Founding of Doğru Haber, Hizbullah's weekly newspaper \\
\hline 2009 & $\begin{array}{l}\text { The AKP government's secret meetings with PKK leaders, known as the Oslo } \\
\text { Process }\end{array}$ \\
\hline 2009 & $\begin{array}{l}\text { The AKP's declaration of "Democratic Opening," popularly called "Kurdish } \\
\text { Opening" }\end{array}$ \\
\hline 2009 & Utilization of Said Nursi figures in ethno-nationalist rallies \\
\hline 2009 & $\begin{array}{l}\text { Mass public rally to protest Israel's attack on the Gaza Strip organized by } \\
\text { Hizbullah }\end{array}$ \\
\hline 2011 & The beginning of the ethno-nationalists' Civil Friday Prayers campaign \\
\hline 2012 & The closure of Mustazaf-Der, Hizbullah's charity organization \\
\hline
\end{tabular}




\section{Years}

2013 The establishment of HÜDA-PAR, legal political party of Hizbullah

2013 Newroz declaration by the PKK and beginning of a long ceasefire, known as "Peace Process"

2013 The eruption of the corruption scandal and beginning of the AKP-Gülen rift

2014 Mass Kobane protests and violent engagement between PKK and Hizbullah militants

2015 Joint declaration of AKP and pro-Kurdish HDP calling the PKK's farewell to arms

2015 Invigoration of violence after HDP's electoral victory (and AKP's defeat) in general elections, signaling the end of the Peace Process 


\section{Civic Competition and Conflict Transformation}

To explain social action is akin to explaining why a grand master allowed a knight to exchange for a pawn (in a chess game), as opposed to considering this an error on the order of $3-1=2$ (the difference in points between the two). We cannot say in advance how far we must go in our quest to determine the context that led to this move, but this indeterminacy is simply the minimal flexibility required to understand complexity.

- John Levi Martin

A quick glimpse at the numbers shows that there has been a de-escalation of ethnic conflict in Turkey. The number of officially called "terrorist" attacks has dramatically decreased in the past decade (Figure 4.1). The PKK fighters killed or captured by Turkish security forces are now far fewer when we compare the current numbers with the ones in the $1990 \mathrm{~s}$ (Figure 4.2). Similarly, civilian deaths and fatalities of security forces have become limited (Figure 4.3). These figures highlight (a) a dramatic decrease of ethnic violence in the early 2000 s (b) a revival of violent contention after 2004, primarily due to rearmament of the PKK in 2004, and (c) a controlled ethnic violence in the recent past decade, fluctuating but never as deadly as it was previously in the 1990 .

An organizational perspective may be useful to explain the PKK's radicalization after the EU-led reforms (2002-2004) in Turkey. Why did the PKK start to attack the Turkish State - breaking the long truce declared in 1999 - at a time when the Turkish State had taken the most promising democratic steps in its modern history? After all, is not democratization "the coffin of revolutionary movements" ?' In his insightful study, Güneş Tezcür explains the PKK's radicalization by pointing out the PKK's increasing organizational concerns after the reform period. The PKK is the leading organization of the Kurdish ethno-nationalist movement; and yet, as an armed guerilla organization, the PKK has private organizational interests and goals. These interests and goals may not fit the larger movement's priorities in the long term. Tezcür rightly notes that the AKP's growing 
Figure 4.1 The number of terrorist attacks between 1994 and 2009

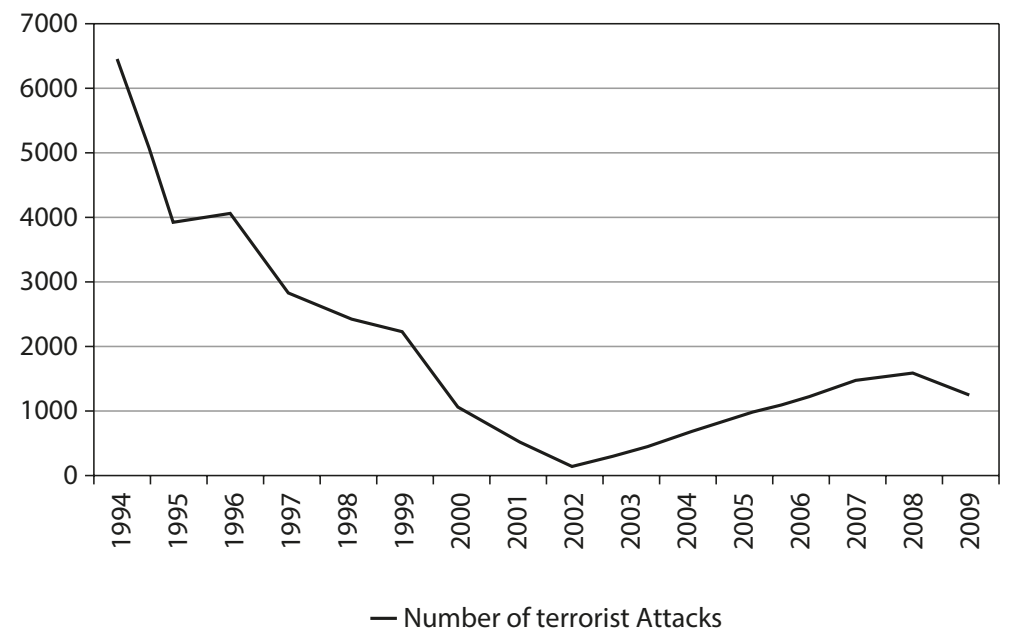

Sources: The General Staff of the Republic of Turkey; the General Directorate of Security; 2009 Annual Report of the Turkish Armed Forces' Gendarmerie Commandership

Figure 4.2 The number of PKK fighters killed or captured by Turkish security forces as well as those who surrendered

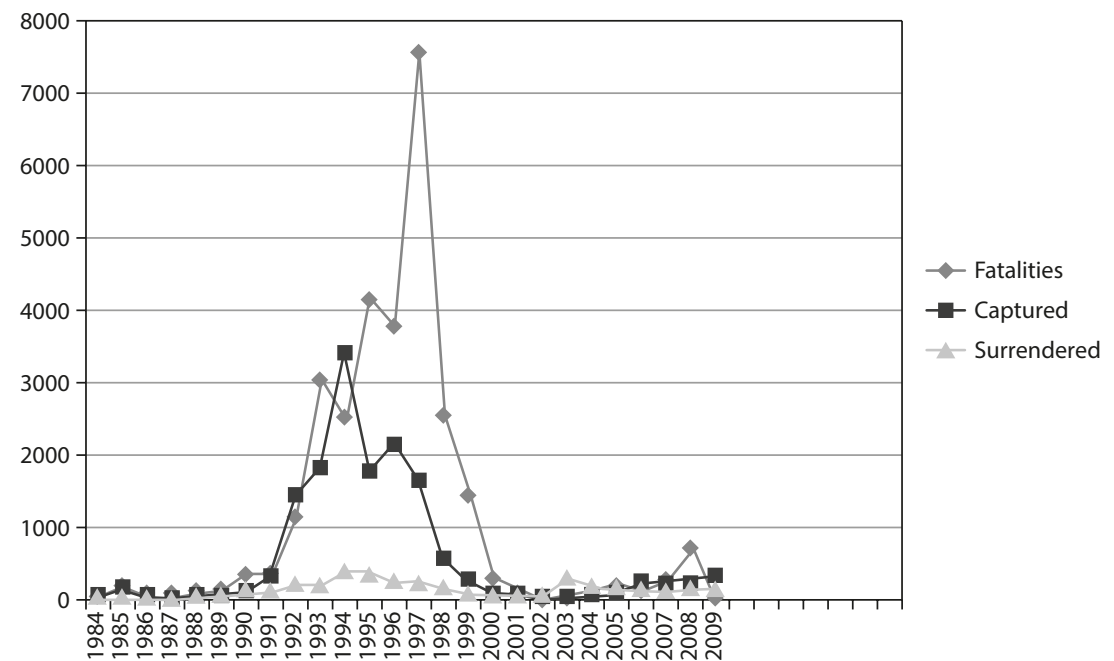

Sources: The General Staff of the Republic of Turkey; the General Directorate of Security; 2009 Annual Report of the Turkish Armed Forces' Gendarmerie Commandership 
Figure 4.3 Fatalities of security forces and civilians since the PKK insurgency

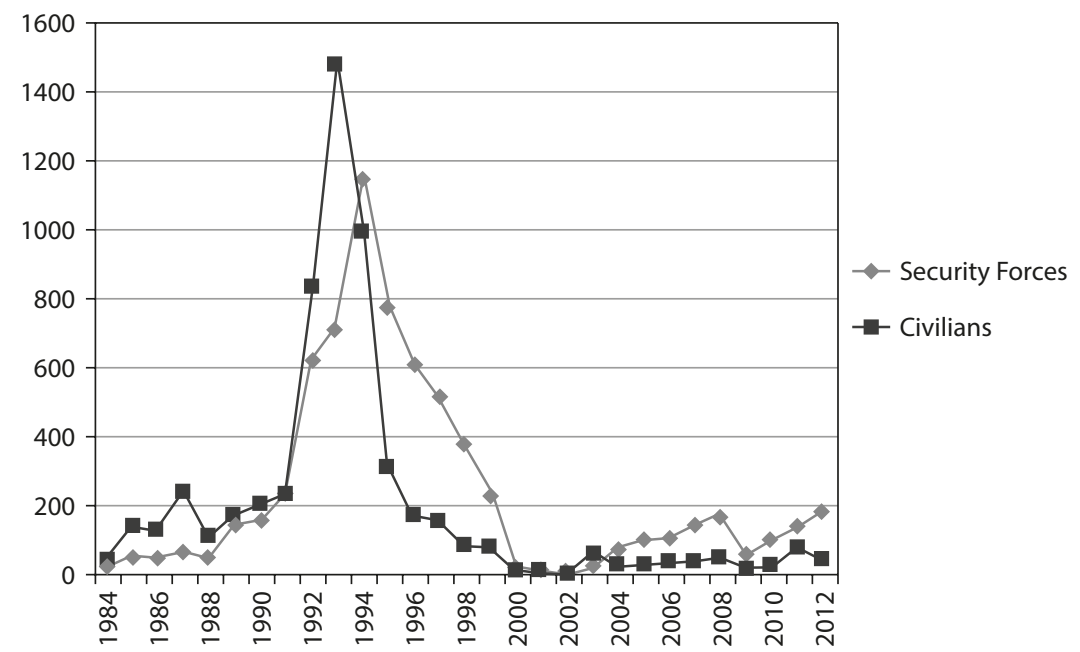

Sources: The General Staff of the Republic of Turkey; the General Directorate of Security; 2009 Annual Report of the Turkish Armed Forces' Gendarmerie Commandership. Post-2009 figures are gathered from the Kurdish Insurgency Violent Events dataset, presented in Tezcur 2013: 70

appeal within the Kurdish constituency has caused fear and reaction in revolutionary circles. ${ }^{2}$

The organizational perspective, however, remains limited in its understanding of competition because it specifically focuses on electoral competition. If we miss the larger picture of competition in Kurdish civil society, we may not grasp the third pattern above, the controlled ethnic violence in the past decade. How did the ethnic violence in Turkey turn into a controlled violence? Despite not being resolved, the conflict has appeared transformed, and the pro-Kurdish activists have become moderate in their tone. Why did this change happen?

In explaining the conflict transformation in Turkey, I follow Andrew Abbott's perspective as he reminds us that "interactional fields" lie "at the heart of sociology."

What we should require of explanation is that it gives us an account of how such interactional fields work. This account will not be purely causal. For nearly all of these literatures give a large place to free action, often to strategic choice in particular. Second, it will include temporal 
effects of many sizes, for in each of these areas a past of many depths shapes the present. Third, it will also include a complex understanding of social structure, for that too pervades interactional fields at many scales ... [Such works] don't predict what will happen, indeed they suggest that interactional fields are probably too complex for us to predict. But they do show various internal patterns; they do sketch 'rules of the game;' they do portray the limits and possibilities of action in such systems. ${ }^{3}$

Thus, I focus on the interactional fields in which pro-ethnic and pro-Islamic Kurdish activists are actively involved, constructing "social movement competition."

Ethno-religious conflicts are often seen as intractable conflicts in which contention leads to "constant production of new causes."4 Scholars suggest that the parties involved in an intractable conflict should find new ways of thinking, framing, and constructing the "other" in order to stop the vicious circle..$^{5}$ In the words of a leading expert, conflict transformation is a mode "to envision and respond to the ebb and flow of social conflict as life-giving opportunities for creating constructive change processes that reduce violence, increase justice in direct interaction and social structures, and respond to real-life problems in human relationships." ${ }^{\prime 6}$ In this sense, conflict transformation is a socially constructed endeavor. Instead of a call for full stop in ethnic and religious conflicts, it is an effort to channel what Johan Galtung calls "positive conflict energy" to transform social relations. ${ }^{7}$ Social movement activists may become agents in channeling conflict energy to the civic sphere.

In the past decade, competitor movements have mobilized to shape Kurdish civil society through publications, public lectures, communicative civil initiatives, and more importantly, civic organizations. As they engage with these new endeavors in a changing political context, they have generated and reproduced social norms that regulate their competition. These 'rules of the game' have been constitutive of the emerging fields of competition.

Boudreau and Polkinghorn 2008: 175. See, also, Lederach 2003; Kriesberg 2007; Ryan 2007. 
Figure 4.4 Violations of civic organization rights in Turkey (1994-2007)

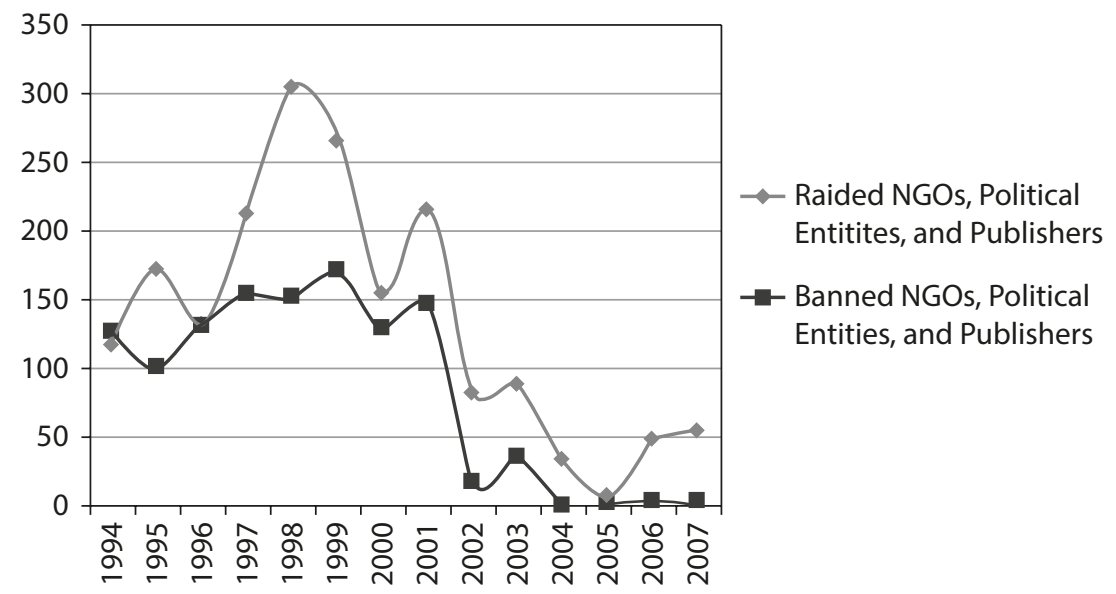

Data collected from online archives of Human Rights Association (İnsan Hakları Derneği)

\section{Emerging Arenas of Competition in the Kurdish Civic Sphere}

For Turkey's Kurds, the post-martial law era has been an era of non-governmental organizations (NGOs): civic associations, charity organizations, reading centers for youth, health service organizations for the poor, women's neighborhood clubs, educational institutes, and Kurdish language study circles. It is hardly a secret that the majority of these undertakings are competitor social movement ventures that have been established in recent years - especially after 2004, the year the EU-induced reforms were realized. Therefore, rival movement activists have started to challenge each other through Kurdish civil society activism.

Legal changes in accordance with the EU membership regulations have encouraged building NGOs in the region. Until 2003, the associations were under scrutiny by the General Headquarters of the Police Department. Figure 4.4 indicates how police raids and official bans on NGOs, political associations, and publishers were very common before the EU membership process.

New regulations have not only made the governorships in each city build their own departments to oversee associations, but they also simplify the paperwork process. This democratic step enabled many Kurdish political activists to actively contribute to associations since the official security check requirement was repealed. 
Figure 4.5 Pace of establishing associations in Diyarbakır, 1935-2010. Numbers indicate how many associations were newly established within the time frames.

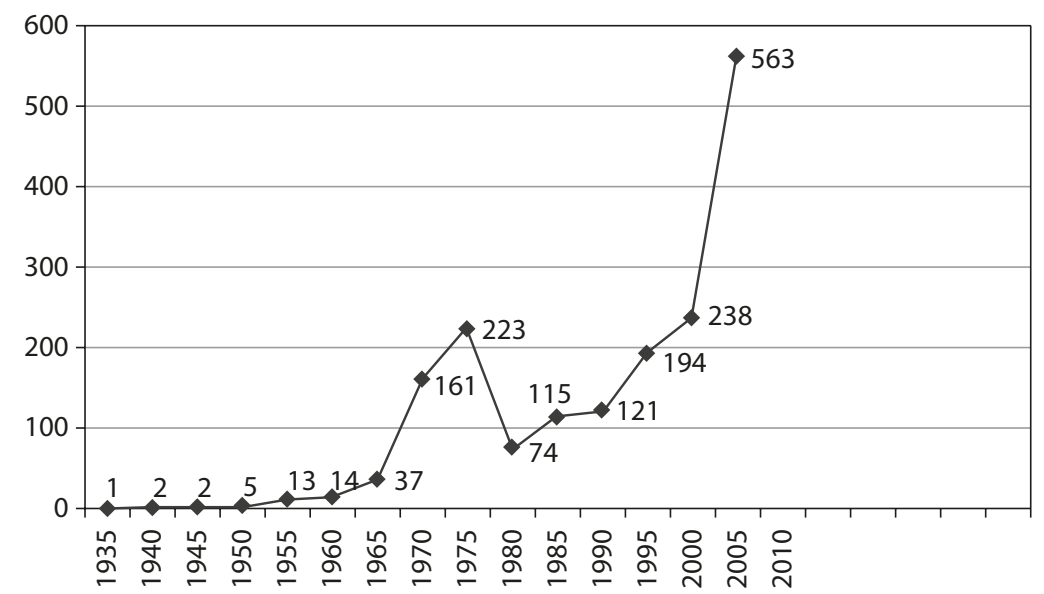

Source: Diyarbakır Provincial Directorate of Associations

Figure 4.6 Pace of establishing associations in Diyarbakır, 2001-2010. Numbers indicate how many associations were newly established within the time frames.

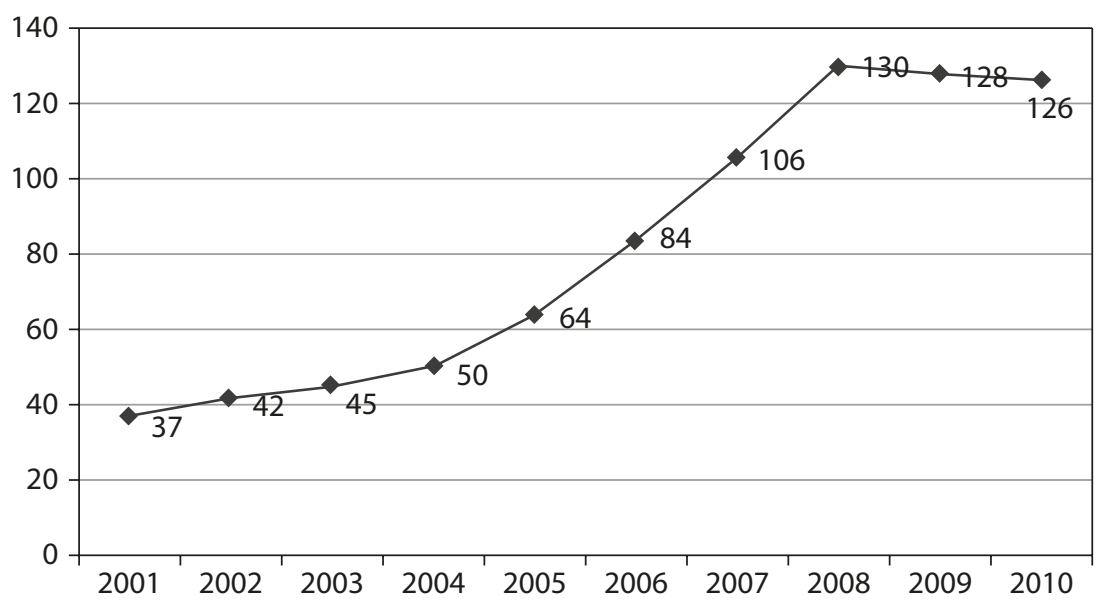

Source: Diyarbakır Provincial Directorate of Associations 
In order to fully comprehend the impact of the recent changes, we need to place the associations in Turkey's historical, political, and legal context. The introduction of a multiparty system in the 1950 s and the modification of laws regarding associations in 1972 had a positive impact on the growth of associations in the nation including Diyarbakır, the largest city in the Southeast. ${ }^{8}$ Figure 4.5 indicates a sharp decline after 1980 , when the military coup took place. The laws of October 71983 that regulate associations (known as Dernekler Kanunu) were particularly restrictive. Under the emergency state and martial law conditions, the establishment of associations was subject to approval by military authorities. Due to the OHAL (Martial Law Conditions) zones in most Kurdish cities during the 1980s and 1990s, associations in the Southeast were under heavy State surveillance until the EU-induced regulations were implemented. The formation of associations skyrocketed in the post-martial law era - which ended in 2002 in Diyarbakır - especially after the European Union membership reforms were enacted (2002-2004). The number of civic associations in Diyarbakır increased rapidly, reaching 714 in 2010. Through civic associations, the major rival movements in the Southeast started to transform Kurdish civil society.

\section{Arenas of Competition and Strategy-Making}

Scholars define contentious spaces for activism in a number of ways including "arenas,"'conflict arenas," and "strategic action fields." In James Jasper's description, "Arenas are sets of resources and rules that channel contention into certain kinds of actions and offer rewards and outcomes., ${ }^{10}$ To put it simply, social movement activists are encouraged, through formal or informal ways, to be involved in certain types of actions such as building charity organizations, helping local communities, utilizing religious symbols, and appealing to scientific authorities.

Neil Fligstein and Doug McAdam highlight how these arenas of competition are socially constructed through activists' engagements with one another: "One can conceive of emerging fields as a social space where rules do not yet exist, but where actors, by virtue of emerging, dependent

8 In 1950, there were about 2,000 associations in Turkey; the number reached 45,000 in 1972. See Toksöz 1983: 377; Hersant and Toumarkine 2005.

9 For these terms see respectively, Jasper 2004; McAdam 1982: 65-116; Fligstein and McAdam 2011.

10 Jasper 2004: 5. 
interests, are being forced increasingly to take one another into account in their actions." ${ }^{\prime 1}$

As perceptive agents, activists are well aware of the emerging arenas for competition, and accordingly, make strategic moves. In Jasper's account,

Protestors may launch action within a certain arena (the media or courts, for instance), but they also think about other possible arenas for future contestation. They ask themselves what new arenas their opponents can force them into, and what resources and skills they and other players control for maneuvering in those arenas. ${ }^{12}$

In a similar vein, "Once a movement enters a particular venue," note David Meyer and Suzanne Staggenborg, "if there is a possibility of contest, an opposing movement is virtually forced to act in the same arena." ${ }^{13}$

These important observations invite further questions: How do activists perceive the "possibility of contest"? What does "possibility" mean for them? In other words, how do rival activists decide if they can compete - or if they would like to compete at all - in particular arenas? I suggest three major factors that significantly influence Kurdish activists in deciding to become involved in a particular arena of competition: mobilizing resources, ideological boundaries, and activists' phronesis.

11 Fligstein and McAdam 2011:11. Fligstein and McAdam (2011:3) defines strategic actions fields as "a meso-level social order where actors (who can be individual or collective) interact with knowledge of one another under a set of common understandings about the purposes of the field, the relationships in the field (including who has power and why), and the field's rules." Inspired by Bourdieu, they rightly highlight that social actors are players developing inter-subjective understanding and "feel for the game" (Bourdieu 1990: 66): "if two or more organizations or groups are attempting to attain ends that are sufficiently similar that they are compelled to take one another's actions into account in their behavior, then we can say that we are observing an attempt at field formation" (Fligstein and McAdam 2012: 167). Fligstein and McAdam's insightful account, however, suffers from some assumptions based on the polity model, or "incumbent versus challenger" approach. In their comprehensive review, Jack Goldstone and Bert Useem (2012) explain how the theory of strategic action fields locates social actors in "the challenger-incumbent model of social relations" and why it is severely problematic. Fligstein and McAdam (2012: 167) concede that their approach to a field membership is a "narrower" one, diverting from a broader view embraced by Bourdieu and Wacquant (1992). The narrower approach views "fields as composed of actors who are orienting themselves to each other but also a defined set of policy goals"; therefore, they could be seen as "policy domain" (Fligstein and McAdam 2012: 167).

12 Jasper 2004: 5.

13 Meyer and Staggenborg 1996: 1649. 
i) Resources: In order to compete in a particular arena, rivals first and foremost have to possess an adequate level of resources. Activists are not only in need of personnel, money, time, energy, and skills but symbolic resources such as reputation and prestige. ${ }^{14}$

ii) Ideology: Ideologies are "prescriptions or maps that tell the individual how to look at events and people," and thus, they serve "both as a clue to understanding and as a guide to action, developing in the mind of its adherents an image of the process by which desired changes can best be achieved." ${ }^{15}$ Activists who are committed to secular or religious belief systems construct certain boundaries that define their own action as legitimate or unacceptable. For example, the Kurdish ethno-nationalism's historical development as a radical socialist movement and Hizbullah's roots in Islamist philosophy shape each group's decisions to invest in some arenas and avoid others.

iii) Phronesis: Another factor that shapes actors' decision whether to become involved in an arena of competition is their "practical know-how." Aristotle's term phronesis, i.e. practical wisdom and everyday habits, is useful in understanding activists' way of addressing social problems and challenges in a particular context. ${ }^{16}$ Phronesis refers to practical wisdom based on experience. Values, emotions, and everyday habits are part of everyday life experience of movement activists. Activists' biographies are not only important for their recruitment processes in social movements but also for their protest lifestyle.

Inspired by Bourdieu's notion of habitus, Nick Crossley suggested the term "activists' habitus" to explain variations in "the taste for contention."17 As James Jasper explains,

Tactics are rarely, if ever, neutral means about which protestors do not care. Tactics represent important routines, emotionally and morally salient in

14 For symbolic resources, see Benford and Zurcher 1990.

15 See, Turner and Killian 1972: 270. Wilson 1973: 91-92 respectively. Despite its significance, the role of ideology is neglected in recent social movement scholarship because of inconsistent and contradictory usage of the concept "ideology" among early scholars - what Pamela Oliver and Hank Johnston (2000: 42) called "the pejorative legacy of ideology."

16 Jasper 1997: 244. Activists' know-how might be conceptualized as "repertoire" (Tilly 1995) but Jasper (1997: 240) warns us to avoid the structuralist trap here: "Protestors do not simply apply existing repertoires; they innovate with them and deploy different combinations at different times. Repertoires, tactical choices within them, and strategic applications of tactics are affected by internal movement culture and individual biographies as well as by external opportunities and the moves made by other players."

17 Crossley 2003: 51-52. 
these people's lives. Just as their ideologies do, their activities express protestors' political identities and moral visions. To participate in NRC hearings or to block traffic in the street outside is to say different things about one's personal identity, a movement's identity, attitudes toward governmental authority, and much else. ${ }^{18}$

Structuralist accounts often reduce tactical tastes to structural position. Tastes in tactics, in fact, are deeply embedded in morality, emotion, and cognition.

Pro-Islamic Gülen/Hizmet movement activists in the Southeast, for example, do not want to present their organizations as pro-Islamic. Despite the fact that they perceive themselves as a pious religious movement, Hizmet participants avoid opening NGOs solely for religious purposes and refrain from organizing public rallies for Islamic causes. In his ethnographic study of Turkish-Islamic communities in Europe, Ahmet Yükleyen points out remarkable differences between the Gülen and the National Outlook movements regarding their taste in tactics. The National Outlook highly emphasizes visible pro-Islamic events, whereas Gülen activists often avoid Islamic symbolism in public. ${ }^{19}$

Moreover, forms of civic organization are closely tied to phronesis of Kurdish activists. "Organizations are a form of tactic," argues Jasper, "reflecting cognitive frames, moral tastes, and practical know-how." Organizational forms and names reveal identities, worldviews, and know-how of activists. ${ }^{20}$

Resources, ideology, and phronesis together have shaped the competition processes in the Kurdish civic sphere: first, strategic resemblance through charity organizations; second, strategic distinction through niche activism in various fields; and third, strategic subversion through symbolic contestation over local figures and historical narratives.

Table 4.1 presents how rival movement activists challenge each other. The nature of competition is socially constructed through the interpretive processes of rivalry. Unlike opposing movements, rival movements develop specific norms that regulate their relationship. In arenas where competition is feasible, the rivals resemble one another through charity organizations;

18 Jasper 1997:237. Emphases in the original. Jasper (1997:238) contends that framing literature has been successful in explaining cognitive aspects, but emotional and moral dimensions are largely omitted by social movement scholars. The notion of phronesis might be useful in shedding light on these underdeveloped dimensions.

19 Yükleyen 2012: 25. Similarly, Bekim Agai (2005) points out that prioritizing education over religious representation in public is a general organizational strategy of the Hizmet movement. 20 Jasper 1997: 244. Clemens 1996: 207; Ghaziani 2011: 99. 
Table 4.1 Processes of rivalry in the Kurdish civil society

\begin{tabular}{ll}
\hline Arenas where competition is... & Process \\
\hline Feasible & Resemblance \\
Restrained & Niche Building \\
Symbolic & Strategic Subversion \\
\hline
\end{tabular}

whereas in arenas in which competition is restrained because of resources or ideology or activist phronesis, the rivals engage in niche building for differentiation. In arenas where competition is highly symbolic in nature, however, the rivals engage in subversive tactics and aim to articulate their authentic Kurdish ethnicity through cultural repertoires such as local historical figures and narratives about the state.

The first two mechanisms, in fact, are two interrelated processes, what we might call resemblance and niche building. On the one hand, rival movements vie for the support of local Kurds through charity organizations as long as competition is feasible, which is determined by three major factors (i.e. available resources, ideological openness, and supportive phronesis). On the other hand, the rivals seek to construct their specific niche in certain arenas where their competitors cannot possibly challenge them, e.g. the Kurdish ethno-nationalists' strong emphasis on women's organizations is most meaningful when we consider the conservative ideological stance of Hizbullah and the Gülen movement, who are reluctant to participate in the field of women's self-determination activism. Likewise, the Gülen movement's specialization in educational centers and Hizbullah's particular focus on religious associations are indeed related: Hizmet activists often avoid having a public image through religious organizations, and thus, the religious field becomes wide open for Hizbullah. Also, Hizbullah lacks the resources for educational mobilization.

The third process, strategic subversion, occurs when the rival activists engage in contests in symbolic spaces. Unlike the first two mechanisms, symbolic contestations could simultaneously occur in various institutional settings of Kurdish civil society and constitute a symbolic field of competition. Strategic subversion refers to activists' collective attempt to claim symbolic resources such as religious repertoires and local historical figures in order to both strengthen their own prestige and harm the reputations of their competitors.

A major symbolic contestation occurs in Kurdish Islamic space, which has become an arena of competition especially after the increasing activism 
Figure 4.7 Kurdish Islamic symbolic space as an arena of competition

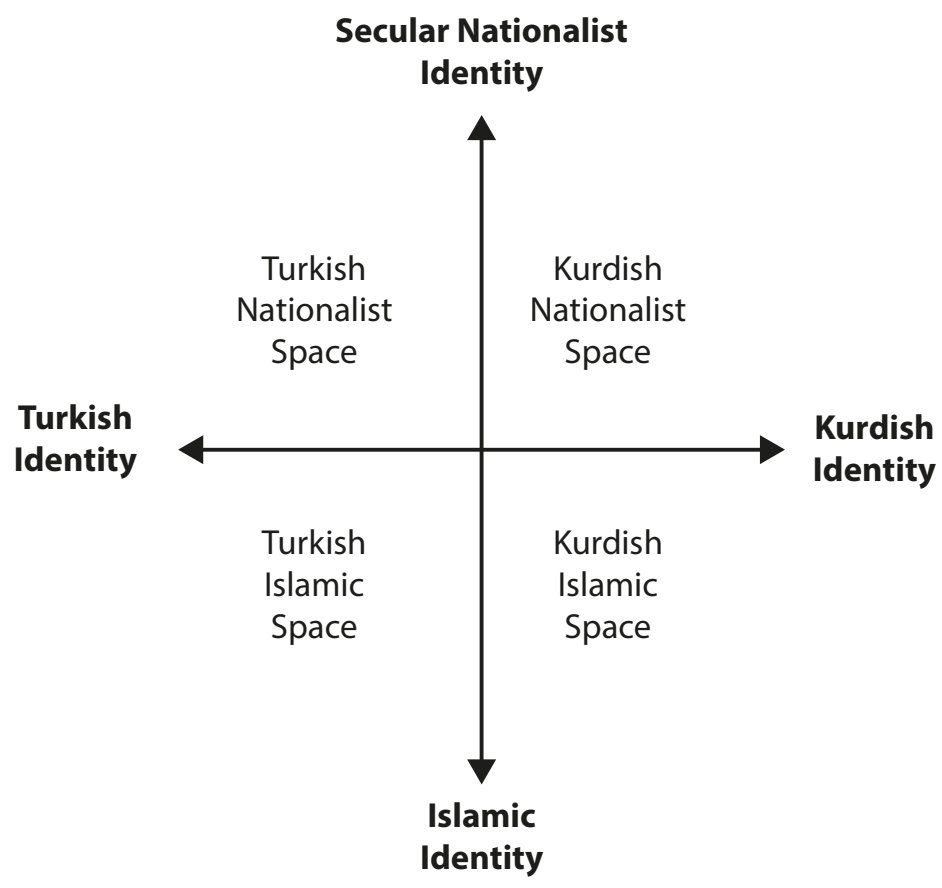

of the pro-Islamic ruling party, AKP, and the Gülen movement, which were traditionally in the Turkish Islamic space (Figure 4.7). Defending secular Kurdish identity, Kurdish ethno-nationalists operate in the Kurdish nationalist space; yet, they increasingly move towards the Kurdish Islamic symbolic space. Until the pro-Kurdish reforms in 2004, Hizbullah heavily emphasized its Islamic identity and never capitalized on ethnic Kurdish identity. In recent years, however, Hizbullah has increasingly become closer to Kurdish ethno-nationalists in terms of its emphasis on ethnic identity.

Thus, the rival movements in the Southeast have increasingly become active in defining Kurdish Islam and local historical figures. These strategic engagements, however, have always been relational; simultaneously reinforcing their prestige (re-construction) and de-legitimizing their competitors (de-legitimization). 


\title{
$5 \quad$ Resemblance and Difference
}

\author{
Constructing Kurdish Civil Society
}

Some 2,500 years ago, Greek phalanx warfare was based on the confrontation of two lines of soldiers on a battlefield, each armed with a shield on the left arm and a spear or sword in the right hand. John Levi Martin explains how these "rules" were deliberately undone precisely because they were accepted as the rules of warfare:

These two lines would slowly rotate in a counterclockwise direction ... each soldier's right side was protected only by the shield of the man to his right. As each instinctively moved closer to the right, the line shifted; to keep the lines aligned, the right flanks would move forward. Captains, aware of this 'law,' tended to put the most valiant fighters on the right side, as they would lead the aggression into the enemy's side. But the most interesting thing about this 'law,' of course, was that it was not a law at all, though it was repeated for generations. Then the Thebans, though vastly out-numbered, won a major battle over Sparta at Luectra by concentrating their forces on the left instead of the right and breaking through this side of the Spartan phalanx. ${ }^{2}$

The Spartan case illustrates the significance of agency in shaping the rules of a particular social game.

In transforming their deadly fight into a culture of relatively benign competition, Kurdish activists discovered an unprecedented means in the region: establishment of non-governmental organizations. These civic spheres of influence have begun to emerge as new "competition arenas." Neil Fligstein and Doug McAdam propose four elements of structure for emergence of such fields:

1 a common understanding of what is at stake in the field,

2 a set of players with known positions in the field,

3 a common understanding of the rules in the field,

4 and finally, a way for actors to interpret the actions of others and frame their own as the 'game' is being played. 
In the Kurdish case, these elements remain fluid and are still under construction. Kurdish ethno-nationalists or pro-Islamic activists are not yet clear about the nature of the "rules" in the civil society competition: "A common understanding about the nature of the 'rules' in the field means that actors understand what tactics are possible, legitimate, and interpretable for each of the roles in the field. This is different from knowing what is generally at stake. This is the cultural understanding of which moves make sense as interaction in the field plays out." ${ }^{2}$

Through the theoretical lenses of Fligstein and McAdam, Kurdish civil society could be seen as an "emerging field" that has many "arenas" of competition. The authors suggest a kind of analytical awareness useful in studying such cases:

One of the tasks facing scholars is to figure out at the emergence of a strategic action field what are the realistic projects ${ }^{3}$ that might actually happen ... Where things are fluid, our approach forces the analyst to consider all of the possible alternatives in that situation. If there are multiple collective projects available, then the analyst must focus on what they are and consider how the actors involved choose to engage in strategic action. While resources available to actors in emergent situations matter a lot, the ability to engage in creative forms of collective action that involve expansion of collective identities can be pivotal. ${ }^{4}$

Following these valuable suggestions, we may wonder why certain "collective projects" such as the establishment of charity organizations have rapidly become an arena of social movement competition in Southeastern Turkey.

2 Fligstein and McAdam 2012: 170.

3 The authors see these projects as an outcome of social negotiation: "Before a single set of rules governing action emerges, one can speak of competing definitions of the situation. These varying cultural conceptions can be viewed as projects that given sets of actors are trying to create and impose on other actors. During the emergence of a strategic action field, there may be much confusion about these projects. It is up to the analyst to try and figure out which cultural conceptions might end up dominating." Fligstein and McAdam 2012: 171.

4 Here, Fligstein and McAdam (2012: 172) suggest a process analysis over a structuralism: "Taken together, our view forces the analyst to do more than just tell the story of how the winners were inevitable. Instead, the analyst must carefully specify the players, consider their resource endowments, understand the nature of the collective projects at stake, and study what courses of actions were possible and then successful or unsuccessful. This will force the analyst to uncover surprising or subtle results." 
Figure 5.1 Arenas of competition and situation of the actors

\begin{tabular}{|c|c|c|c|c|c|}
\hline & Actors & Resources & Ideology & Phronesis & Involvement \\
\hline \multirow{3}{*}{ Charity } & Ethnonationalist & + & + & + & High \\
\hline & Hizmet & + & + & + & High \\
\hline & Hizbullah & + & + & + & High \\
\hline \multirow{3}{*}{ Education } & Ethnonationalist & $+/-$ & + & + & Moderate \\
\hline & Hizmet & + & + & + & High \\
\hline & Hizbullah & - & + & + & Low \\
\hline \multirow{3}{*}{ Women } & Ethnonationalist & + & + & + & High \\
\hline & Hizmet & + & $+/-$ & - & Low \\
\hline & Hizbullah & + & - & - & None \\
\hline \multirow{3}{*}{ Religion } & Ethnonationalist & + & - & - & None \\
\hline & Hizmet & + & + & - & Low \\
\hline & Hizbullah & + & + & + & High \\
\hline
\end{tabular}

Within only two years, between 2004 and 2006, all major social movements have formed public aid associations. On the other hand, a process of differentiation occurred in these years: Kurdish ethno-nationalists, Hizbullah, and Hizmet increasingly claimed certain civic enterprises as their own "turf," and therefore, challenge one another through niche specialization and professionalism. ${ }^{5}$ As Jasper acutely observes, "Switching arenas is a common way to surprise opponents, avoid defeats, and increase the value of the skills and resources you control. An outcome in one arena is sometimes only a starting point for action in another."

I argue that these two simultaneous processes, i.e. resemblance and differentiation, are closely linked in Turkey's Southeast. In what follows, I provide a map of competition arenas by analyzing charity organizations, educational initiatives, women's associations, and religious institutions (Figure 5.1). As argued in a previous chapter, competitor actors' involvement is highly related with dynamics of resources, ideology, and group phronesis. This chapter, however, adds an interactive dynamic and aims to illuminate the logic of social movement resemblance and difference.

5 On specific forms of movement activity or niches in order to develop expertise and organizational professionalism, see Minkoff 1999; Levitsky 2007.

6 Jasper 2004: 5. 


\section{Why Charity Organizations?}

Applying political clientelism theory to social movement organizations in the Middle East, some scholars argue that social movement associations that target disadvantaged populations aim to recruit new members and establish "networks of patronage and clientship, communal membership and loyalty, and possibly political allegiance." The political clientelism approach is useful in explaining the charity activism of political parties used to gain political support.

This perspective, however, tells less about the dynamics of social movement competition to build legitimacy and reputation. Thus, the political clientelism perspective overemphasizes material exchange mechanisms at the expense of the cultural dynamics of mobilization such as reputation building. In other words, this exclusively economistic approach, which claims that movement-organized charity associations treat people as simple objects of control, disregards the social movements' emotional engagement with their constituency to develop legitimacy and reputation.

Criticizing the political clientelism perspective, Janine Clark's comparative study in Jordan, Egypt, and Yemen documented that social movement organizations for social welfare construct an amorphous horizontal network instead of cross-class vertical ties. Thus, rather than recruiting poor masses, social movements' service sectors "play an important role in the strengthening of horizontal networks" that bind middle-class individuals. $^{8}$

Similarly, research on Hizbullah's non-profit organizations in Lebanon depicts how social services such as charity foundations, free hospitals, scholarships to students, and financial aid to the families of "martyrs" are very significant in constructing public legitimacy and reputation. ${ }^{9}$ Likewise, despite the pressure from Western nations, Hamas' provision of free social services such as housing, food, health care, and schooling to needy Palestinians has provided international recognition and legitimacy on behalf of Palestinians, especially in Muslim-populated countries. ${ }^{10}$

I argue that social movement charity organizations in Southeast Turkey should not be conceptualized as separate entities that seek political

7 Zubaida 1992: 9; see also, Al-Sayyid 1993. For the political clientalism perspective, see Schmidt et al. 1977; Gellner and Waterbury 1977. For criticisms of the perspective, see Auyero 1999; Wang and Kurzman 2007; Auyero, Lapegna, and Poma 2009.

8 Clark 2004: 4.

9 Flanigan and Abdel-Samad 2009; Khatib et al. 2014.

10 Crooke and Shields 2005; Brynen 2008. 
allegiance. Instead, the charity activism is a form of reputation work, and the charity organizations are public relations departments of Kurdish social movements. I define reputation work as activists' collective attempts to shape their public image. Concerned about their public representation, Kurdish activists are actors in a field of rivalry where strategic calculations are not made in a rigid economistic way but through inter-subjective understanding of rival actors, and therefore, "Once a movement enters a particular venue ... an opposing movement is virtually forced to act in the same arena." ${ }^{\text {11 }}$

Questions remain, however, about why charity organizations and not others are rapidly emerging as PR units? As argued earlier, activists' drive to enter various fields of competition arenas is the result of decision-making processes in which they are primarily concerned with available resources, their group ideology, and their phronesis: (i) As major social movements in the region, the Kurdish ethno-nationalist movement, the Gülen, and Hizbullah have the ability to allocate remarkable resources for donations. (ii) The Kurdish ethno-nationalists' leftist ideology, as well as Islamic worldviews of the Gülen movement and Hizbullah, clearly encourages social welfare programs. (iii) Having long histories of public assistance, these three groups are able to mobilize masses in a natural flow as the Kurdish community has experienced turbulent times after migration waves to the cities. Accordingly, this is an outcome of common sense and a practically viable project. Framing themselves as helping hands, the rival activists are not only winning the minds and hearts of the local Kurds but are also developing legitimacy in the eyes of Turkish state officials and the general public in Turkey. Thus, the rivals' concern for building reputation and legitimacy goes beyond the economistic approach of the political clientelism perspective.

\section{Exogenous Shocks: Increasing Poverty and the Emergence of Kurdish Slums}

Context is crucial in analyzing competition arenas. Understanding the competition in the Southeast entails a vigilant analysis of Kurdish migration waves. Hundreds of thousands migrated from rural areas to urban centers during the bloody fight between the PKKand the Turkish State in the early 199os. Most of these migrations were dictated by state agencies in order to eliminate logistical support for the PKK. As of 1994, 1,046 villages had been evacuated as a result 
of the State's displacement policy, 812 of them as a result of PKK pressure, seventy-five due to security reasons, and thirty-four for economic causes. ${ }^{12}$

Kurdish migrants have become the new urban poor in Turkey. There is no reliable empirical data available for the total number of migrants. The most comprehensive official document on the issue is the report of the Turkish parliamentary investigation committee, published in 1998. The report notes that, up to 1997 , the number of migrant people was $378,335 .{ }^{13}$ And yet a proKurdish nationalist immigrant rights organization, Migrants' Association for Social Cooperation and Culture (Göç-Der), claims that the number may be as high as three million, "when the definition of the displaced is broadened to encompass those forced to leave their homes by armed clashes, the destruction of fields and pastures, army-imposed food embargoes and threats by state security forces, state-employed 'village guards' and the PKK." ${ }^{{ }^{14}}$

If we consider only the 1990 and 2000 census results of the largest Kurdish city, i.e. Diyarbakır, the urban population rose by about $37 \%$, from 595,440 to $817,692 .{ }^{15}$ As a result of the massive migration that occurred between 1990 and 1995, ninety-six nearby villages expanded and became the shantytowns of Diyarbakır. Ghettoization has become a fact of everyday life in the city where $40 \%$ of the population is below the poverty line according to UNICEF's records in 2000. ${ }^{16}$ According to a study conducted by the Diyarbakır Chamber of Commerce and Industry, the unemployment rate reached as high as $70 \%$ in the city in the early 2000 s. $^{17}$

My field observations in Diyarbakır were eye-opening beyond the statistical data. I met with Welat, a Koma Civaken Kurdistan (KCK) activist, in order to learn more about the ethno-nationalist organizations in the city. ${ }^{18}$ He took me to his friend's house for a meal. It did not take too long before our conversation's focal point became the financial struggles of Kurds. Welat reported his exchange with a Kurdish migrant who had ten children:

\footnotetext{
12 Şimşek 2006: 45.

13 The report also notes that the eviction of villagers was "unlawful" as being "de facto action carried out by the security forces" (Quoted in Yükseker 2007a: 147). For other reports on the issue, see Kurban et al. 2007; KMD 2010.

14 Day 2008: 24. Based on a recent survey conducted by KONDA, Erdem Yörük (2012:521) gives a similar estimate.

15 Yükseker 2007b: 175 .

16 Uslu 2009: 196.

17 Another survey (Yükseker 2007a: 153-54) shows how the migrants have low levels of education $(61 \%$ of women and $28.5 \%$ of men are illiterate) and experience $(87 \%$ earned their livelihood from agriculture before the migration). As uneducated farmers, the migrants have competed for unskilled jobs where employment opportunities have been tight.

18 All names are pseudo names throughout the book to maintain confidentiality.
} 
Figure 5.2 Child labor is an everyday reality in Diyarbakır

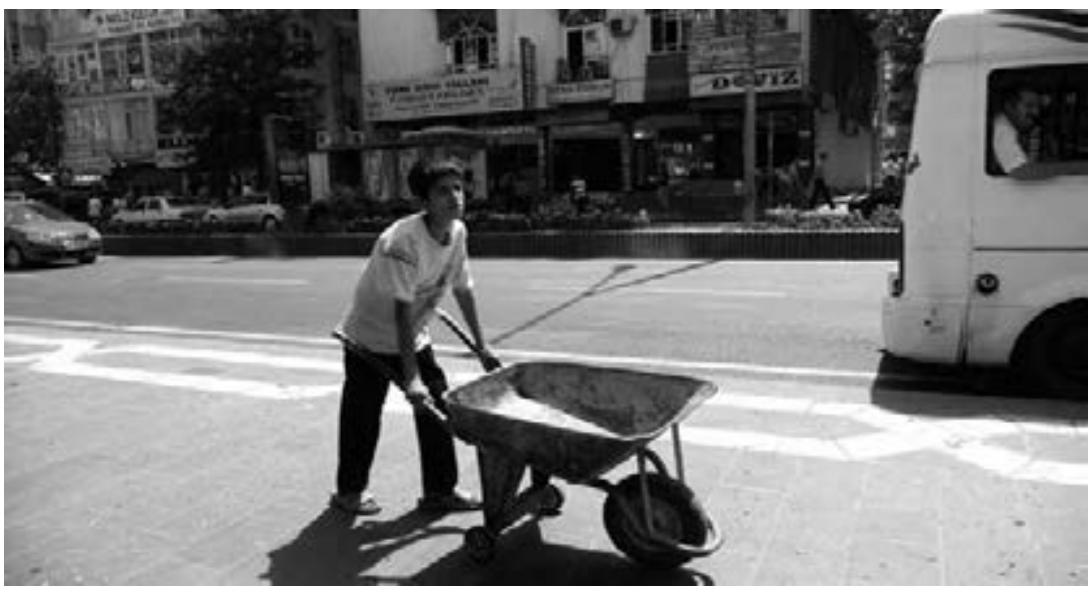

Photo by the author, July 22, 2009

"Knowing the hard conditions he lives in, I asked him why he made so many children. He reacted like, 'How could I know that we'd be miserable like this? In a typical village, you think that you would need many kids for helping you out as some would go to farming, others put animals out to pasture, and so forth'." ${ }^{19}$ In Diyarbakır, unemployed youth and porter kids are ubiquitous and are to be seen every day.

Increasing poverty in Kurdish cities has become a nationwide problem. Unlike in other regions in Turkey, governing institutions and political parties are highly involved in donations and public assistance programs. ${ }^{20}$ Unsurprisingly, activists of all social movements are encouraged to take part in this effort. By doing so, they get recognition from the authorities as well as support from the grassroots. After the EU-initiated pro-Kurdish reforms (2002-2004), Hizbullah, the Gülen/Hizmet, and the Kurdish ethnonationalist movement have rushed to form charity organizations. ${ }^{21}$

19 Author's personal communication. Diyarbakır, July 12, 2009.

20 Yörük 2012: 523.

21 In order to get full support from outside sources, these rival movements establish official associations as their charity organizations. In Turkey, funding of associations is mainly through donations. Only those associations that are recognized Kamuya Yararlı Dernekler, i.e. associations that are categorized as being of benefit to the general public, can receive the state's subsidies. European Union funds are also available if the associations can prove their public utility. Similarly, funds from local municipalities could be easily allocated to associations, providing that they benefit the public at large. Electoral success of the pro-Kurdish parties in 


\section{Constructing Competition through Resemblance: The Charity Initiatives}

The Gülen movement's nationwide charity organization Kimse Yok Mu began opening branches in the Southeast in 2004. ${ }^{22}$ In 2006, after severe flooding struck cities in the region, Kimse Yok Mu distributed the equivalent of almost 2 million euros worth of supplies. Hizmet activists especially regard the Islamic Feasts as occasions for charity distribution. Kimse Yok $\mathrm{Mu}$ annually sets up Ramadan tents and distributes meat packages during the Feast of Sacrifice, a global Islamic ritual known as Eid Al Adha. Launching a major campaign, the organization aided about 17,000 families in 2006 and 60,000 families in 2007 in celebration of the Feast of Sacrifice. ${ }^{23}$

One particular feature of the Feast aid is striking: local Kurdish Hizmet activists invite Turkish Hizmet activists from the western regions of Turkey to attend the Feast observation and make donations to the families directly. Each year, thousands of Turkish activists distribute meat packages during the Feast of Sacrifice, visiting the region for the first time in their lives. ${ }^{24}$

Alpay, a local representative of Kimse YokMu, told me that this is a helpful way to make bridges between Kurds and Turks. Alpay narrated a story of a businessman from Istanbul who was so prejudiced against Kurds that he was not employing them in his factory. As a donor to Hizmet initiatives in Istanbul, he was invited to participate in one of the Feast of Sacrifice campaigns by Kimse Yok Mu. After visiting the region for the first time and distributing meat packages, the businessman regretted that he was a bigot.

Hizmet activists call these aid campaigns "brotherhood" events. In 2007, launching the second annual campaign, Deputy President Eyüp Tok held a press conference. He stated:

local elections has led Kurdish ethno-nationalist activists to become officials in local municipalities (Watts 2010), and thus, enabled them to allocate these resources in their charity activism. 22 Kimse YokMu has its origins in a show with the same name on Samanyolu TV, the movement's TV station, in 2002. Kimse Yok Mu literally means “Isn't anyone out there (to help)?” Although the organization's primary focus is relief rather than poverty alleviation, it has paid attention to victims of endemic poverty in the Southeast. Kimse Yok Mu branches had rapidly mushroomed all over Turkey by 2007 .

23 Hizmet volunteers organize similar campaigns worldwide. By the Feast of Sacrifice 2008, over 1.5 million people in more than fifty countries were recipients of meat packages (Michel 2008).

24 At the initial phase of the campaign in December 2006, for example, 18,073 people from western Turkey visited the region as Kimse Yok Mu volunteers (Koç 2013: 191). 
Figure 5.3 Kimse Yok Mu activists from western Turkey in the slums of Diyarbakır

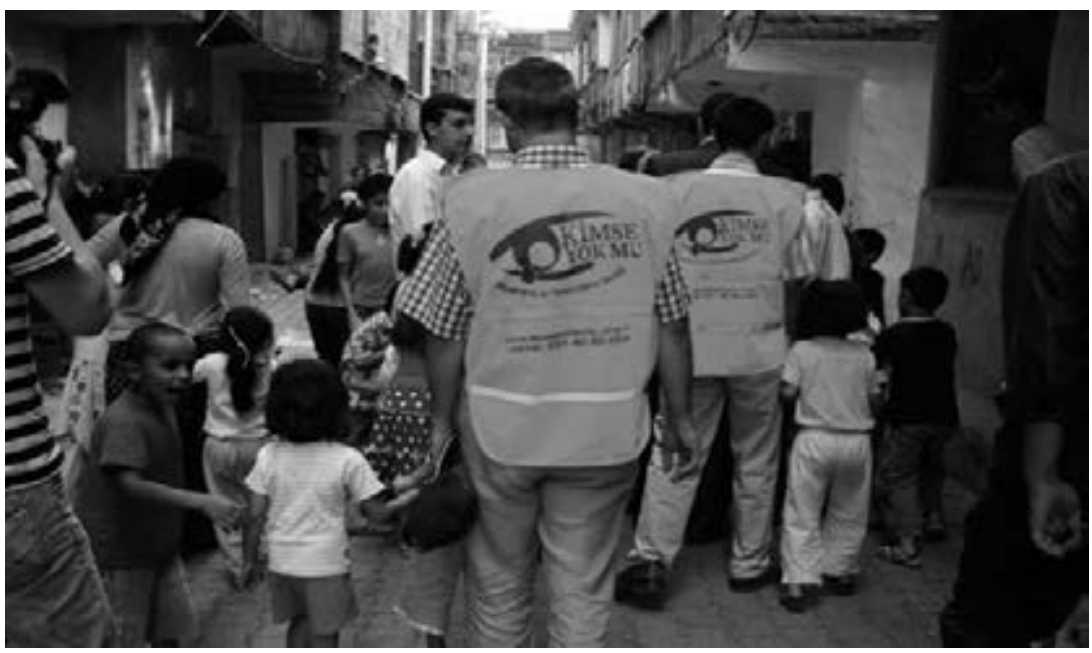

Courtesy of Kimse Yok Mu

There is a very meaningful demonstration of solidarity now occurring in these cities thanks to our foundation. Some 2,00o İstanbul residents will come to the Southeast this year during the Feast of the Sacrifice and pass out meat to the poorer families. The name of our foundation already explains what we aim for: solidarity and assistance. I believe we will be able to give a wonderful message of unity and togetherness this year, as we did last year. ${ }^{25}$

An economistic approach would fail to comprehend the Hizmet way of providing charity: channeling donors themselves to the region instead of their contributions. It makes sense, however, when we consider the movement's broader agenda that promotes Turkish-Kurdish unity around Islam. Moreover, the Gülen movement appears to aim at strengthening the emotional attachment between its Turkish and Kurdish activists as some within the group become increasingly uneasy with the pro-Kurdish reforms. These trips serve as an eye-opening self-education experience especially among those who have a Turkish nationalist background. ${ }^{26}$

26 The Gülen movement recruited large number of Nationalist Action Party, MHP, supporters after the 1980 military intervention. The opening of schools in Turkic states in Central Asia in mid-1990s triggered this trend. See, Turam 2004: 361 . 
The charity activism has been crucial in providing a public message that Hizmet is becoming a major social actor in the region. There is a need to highlight an indirect political outcome: until the recent rift between the two groups, the AKP government benefited the movement's charity activism because of the movement's long-term support for the AKP policies in the Southeast. In fact, like all political parties, the AKP makes donations to the poor especially before election periods. Yet, Hizmet activists' persistent charity efforts benefited the AKP since it was framed as a sign of Islamic brotherhood. It further contributed to the association of these two groups as a unified Turkish-Islamic front in the eyes of Kurdish ethno-nationalists until 2014. ${ }^{27}$

The competition in charity activism escalated, especially after the 2007 general elections which were interpreted as a major success for the AKP. "Kurds are deceived by the AKP's propaganda," said the co-chairman of the pro-Kurdish party, Ahmet Türk, in his evaluation of the election results. "The AKP gives assistance to Kurds in order to make them beggars ... We see some efforts to break people's resistance in the region through using religion. All of these efforts are organized in accordance with a certain plan. We are confronted with a policy to deceive the public." ${ }^{28}$ In a similar vein, the other co-chairman, Emine Ayna, exhorted her audience at a political rally by asserting that the AKP "exploits" the Kurdish people's religious feelings "through relying on the Gülen movement." ${ }^{29}$

Soon after the 2007 election, however, Kurdish ethno-nationalists' charity efforts began to resemble those of their pro-Islamic rivals in such a way that some criticized the ethno-nationalists for doing "almost everything they denounced before. ${ }^{3^{\circ}}$ These actions include the distribution of food packages and organizing free breaking-fast (iftar) dinners during the sacred month of Ramadan and dispensing meat packages during the Islamic Feast of Sacrifice. ${ }^{31}$

Among the major ethno-nationalist initiatives is Sarmaşı, the Association for Fighting against Poverty and Providing Sustained Development. Founded in 2006, the head of its executive board is Osman Baydemir, a popular pro-Kurdish party member and then-mayor of the Diyarbakır

27 Olson 2009: 63-65. Up until the recent tensions, the two actors, the AKP and the Gülen, were seen as unified. In October 2013, attending Kimse Yok Mu's $7^{\text {th }}$ annual campaign in the city of Batman, Minister of Finance Mehmet Şimşek spoke highly of the organization and distributed meat packages to the needy families (Zaman 2013a).

28 Radikal 20o8b.

29 Radikal 2008c.

30 Tulyum 2008.

31 Zaman 2008b. 
Metropolitan Municipality. The organization's food bank provides monthly supplies to more than 2,00o households that consist of seven family members on average. Similar to other Kurdish ethno-nationalist organizations, Sarmaşık substantially relies on funds from the Diyarbakır Metropolitan Municipality.

Sarmaşık's representative Afran believes that there is a systematic State campaign to make Kurds impoverished. "Giving assistance is not a solution," he said in our conversation:

Unless you have a sensible social policy agenda, it just creates more dependent personalities and further pushes people into poverty. That's why we have been against the logic of hayır (i.e. Islamic charity). And yet, we felt the need to do something because there are hungry people suffering out there..$^{2}$

Afran criticized the AKP and other Islamic groups for exploiting Kurds through "the logic of hayır." Pointing out the fact that his family lineage has both Sunni and Alevi roots, Afran said that he is not against AKP's Islamic identity and no one can remain oblivious to religion in "Kurdish geography." He elaborated his criticism of Islamic charity logic: "It is not a sustainable model ... Free distribution of food packages in Ramadan? Those who are not needy also rush to get them! Is this a development model?"

Afran was also critical of pro-Kurdish party municipalities that emulated the Islamic groups by distributing food packages during Ramadan. He mentioned that the municipalities felt the pressure from local people who spoke highly of Diyarbakır Governorship assistance and requested similar aid. Local Kurds perceive benefits by the Governorship of Diyarbakır as AKP's helping hands. "What the Governorship is doing is wrong," he contends. "Should we follow their path?" A year after my conversations with Afran, the Governorship of Diyarbakır sued the Diyarbakır Metropolitan Municipality, claiming that the funding of Sarmaşık is illegal. The court finally decided to suspend the funds from the Municipality on the grounds that Sarmaşı is not recognized by the Council of Ministers as an association that works for public benefit. ${ }^{33}$

Another major ethno-nationalist organization is Gün Işı̆̆ı, an association opened by Bağlar Municipality in 2007. Specialized in clothing, Gün Işığı helps about 30,000 people. Gilyaz, the association's representative, claimed 
Figure 5.4 Headquarters of Sarmaşık, the Association for Fighting Against Poverty and Providing Sustained Development

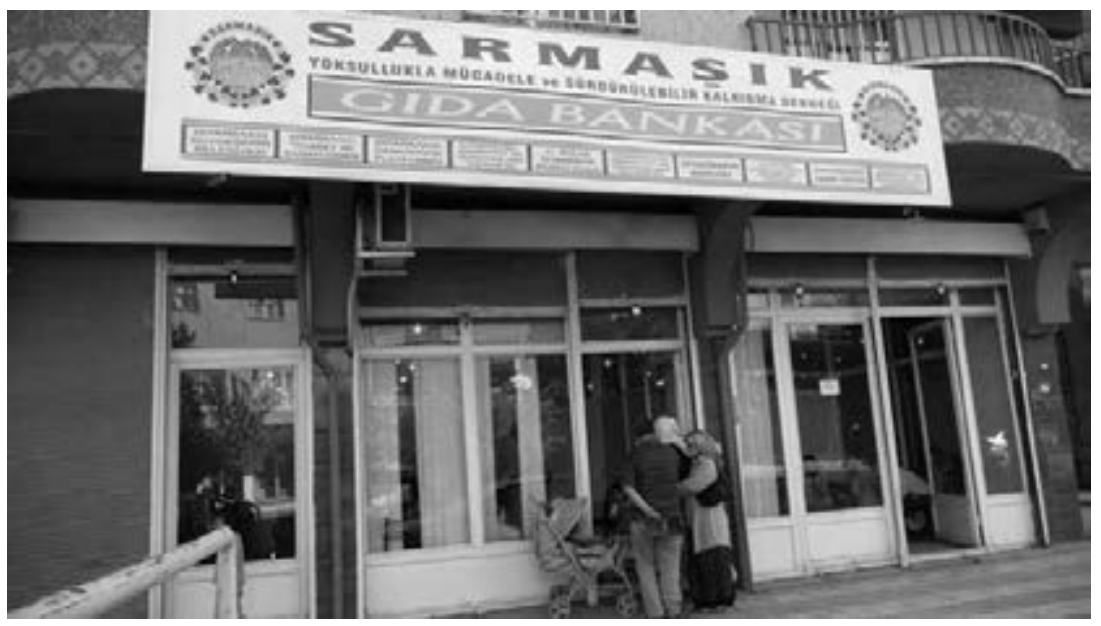

Photo by the author, Diyarbakır, July 17, 2009

that Kurds are sufficiently politicized and smart enough to accept the aid from the AKP but not promise their vote in return. According to Gilyaz, some other Islamic groups help "their own people" but not the Kurdish public at large. Gün Işığı, instead, makes family visits to its beneficiaries during the year and gets in close touch with them.

Although she did not clearly spell this out, Gilyaz was perhaps indicating Hizbullah. The first civic association of Hizbullah, Mustazaf-Der, Solidarity Association for the Oppressed, was established in 2004. The opening of Mustazaf-Der provided the group's activists with both a legal umbrella and a new opportunity to renew its public image. Instead of operating as a regular charity organization, Mustazaf-Der was the key institution for the movement through organizing political and cultural rallies, events, and celebrations until its closure by the state authorities in 2012. ${ }^{34}$ Thus Hizbullah's establishment of the charity organization was meant to develop its reputation and legitimacy within its potential constituency.

Mustazaf-Der emulated Kimse Yok Mu in distributing meat and supplies during the religious feasts and the month of Ramadan. In Diyarbakır alone, about 6,000 to 8,00o families are supported during the Feast of Sacrifice 
annually. ${ }^{35}$ The association provided regular monthly financial support to thousands of poor families and students, as well as to those who would like to marry. In its charity activism, Mustazaf-Der prioritizes the families and relatives of detained or maimed Hizbullah activists or those who were murdered in the fight against the PKK in the 199os. Given the fact that the movement's thousands of members were convicted or imprisoned in 2000 , the charity association has provided an "organizational opportunity" by symbolizing the revival of Hizbullah in the public eye. ${ }^{36}$

In fact, pro-Islamic movements and ethno-nationalists resemble each other in their selectivity of target populations. Similar to Hizbullah, the Kurdish ethno-nationalist charity organizations prioritize the families of PKK guerillas in the mountains and the families of those who died for the cause (martyrs). These families are called değer ailesi, family of value, within the movement. The families of those who are imprisoned (or were jailed for some time) or maimed have also been prioritized in charity activism. ${ }^{37}$ In this sense, the charity activism should not be seen as a simple tool to make political allegiance with the pro-Kurdish party; instead, it signifies the emotional engagement of the activists within it.

The rival social movements are also similar in utilizing charity to sustain long-term emotional allegiances with their constituency at large. The mother of a student at Hizmet's educational center Gülpembe reported that a majority of students' families have become included in Kimse Yok Mu's assistance list and receive aid in various forms..$^{38}$ Likewise, Kurdish ethno-nationalist neighborhood organizations work closely with Sarmaşık, channeling aid to those families whose children are enrolled in their youth centers.

\section{"Education is Our Job": The Gülen Movement Goes to Slums}

Adalet Binici, a 14-year-old Kurdish girl in eighth grade, became the champion in last year's Level Determination Examination (SBS), a high school placement test administered by the Turkish government to over a million students nationwide, thanks to the supplementary education and training provided by a prep school run by the Hizmet movement that

35 ILKHA 20ogb.

36 Kurzman 1998: 23 .

37 Author's interviews with two members of TUHAD-DER, Solidarity Association for Families of Detainees and Convicted, and MEYA-DER, Mesopotamia Solidarity Association for Those Who Lost Their Relatives. July 17, 2009. See also, Öcalan 2011c.

38 Author's interview. Diyarbakır, July 22, 2009. 
is inspired by education-savvy Islamic scholar Fethullah Gülen. Coming from a poor family of seven, she did not even have her own room to study in, so she spent most of her after-school time at the prep school studying and preparing for this very competitive exam. ${ }^{39}$

The newspaper account above is a typical report on achievements of Hizmet activists. Having a worldwide education-centered network, the Gülen movement easily mobilizes large numbers of businessmen and experienced teachers to establish and sustain a variety of educational institutions including private boarding schools, prep centers for YGS/LYS (university entrance exams) and OKS (high school entrance exam), ${ }^{40}$ and reading salons (Okuma Salonları).

Although the opening of the private schools and the exam prep centers goes back to the early 1990s, the movement's interest in founding reading salons is a recent development. Unlike other educational institutions, reading salons are built in poor suburbs and are totally free..$^{41}$ The reading salons, in fact, operate as prep centers in almost every aspect: they are set up as separate buildings having multiple classrooms including computer labs, and their full-time teachers provide the tests/documents that are used in the private OKS prep schools of the movement.

These free education services are widely interpreted as an attempt to block Kurdish ethno-nationalist recruitment from slums. In the words of an activist,

The only permanent solution (to the Kurdish issue) is conquering hearts and encouraging education for new generations. That is the way to win our people in the region ... Is there any way that parents want their children to go to the mountains (to join the PKK rebels)? Of course not.

39 Bozkurt 2014.

40 In Turkey, placements to universities and selective high schools are based on nationwide competitive tests. As competition has increased, attending a private prep school has become a norm among students. Having thousands of teacher activists, the Gülen movement owns a significant share in this giant business. As the rift increased between the AKP government and the movement, the Prime Minister called for a shutdown of all private schools. The AKP's decision is largely seen as a blow to the Gülen movement's recruitment channels. The movement has lately been able to get in touch with 200,000 students per year through its prep schools only. The movement-affiliated media protested this decision by highlighting the benefits of the prep schools in Kurdish-populated regions of the country, pointing out that these enterprises operate as a bulwark against the PKK. See, for example, Zaman 2013 b.

41 The reading salons are officially established by EHİDER (Eğitim ve Halkla İlişkileri Geliştirme Derneği), the Association for Developing Education and Public Relations. 
Instead, they excitedly let their kids go to the education volunteers they trust. That is the way to destroy the path to the mountains. ${ }^{42}$

Immense resource allocation for the reading salons also signals Hizmet's grand strategy against the PKK. Since 2006, the movement has established twenty-one reading salons in Diyarbakır (in the city center as well as in outlying districts) alone, serving 3,000 students annually. One of the directors of these salons indicated that maintenance of one single reading salon requires almost 100,000 YTL (about $\$ 55,000$ at the time) annually. ${ }^{43}$ In addition to full-time teachers, some volunteer teachers in public schools work on their weekends. The reading salons are not only active in the Eastern and Southeastern provinces, but also Kurdish-populated suburbs in cities in the west. As early as 2007 , the movement had reached 140,000 students across the country by establishing reading salons in slums. ${ }^{44}$

In Kurdish nationalist circles, opening such reading salons has widely been interpreted as an insidious attack to diminish the PKK. The PKK repeatedly warned it would punish not only those who lease their homes and buildings to Hizmet members but also those who send their children to Hizmet schools. ${ }^{45}$ Some militants attacked the Hizmet institutions in various places. ${ }^{46}$

In general, however, Kurdish ethno-nationalists avoid direct confrontation. The director of a bombed dorm, for instance, told me that they never received any threats from the militants and that the attack was more about the political climate regarding the 2011 general election in Turkey. ${ }^{47}$ Another Hizmet educator thinks that the ethno-nationalists avoid open aggression since the Gülen movement has gained increasing public support in the region, and violent attacks against unarmed teachers like him would only provide further support..$^{48}$

\footnotetext{
42 Gülerce 2007.

43 Author's interview. Diyarbakır, July 22, 2009.

44 YeniAktüel 2007.

45 ANF 2009, 2010a; Taraf 2010.

46 See, Ongun 2010; Birch 2010. Fire bombings of several Gülen institutions including two reading salons in Bağlar/Diyarbakır (Mehmet Kayalar Okuma Salonu and Selahaddin Eyyubi Okuma Salonu), a university exam prep center in Yenişehir/Diyarbakır, a private high school in Hakkari (Hatice Avcı Koleji), and a private dorm for high school students in Cizre are some of these occasions.

47 Author's interview. Diyarbakır, June 11, 2011.

48 Author's interview. Diyarbakır, July 23, 2009.
} 
The PKK leader Öcalan's message also reiterated that Kurdish ethnonationalists consider Hizmet activists rivals instead of deadly enemies. "I consider them neither a sect nor a congregation," said Öcalan in his cell in December 2010, "they are more of a nongovernmental organization across Turkey and the Middle East." He added:

Their role is important. They have quite a dynamic power, and we are also a dynamic power. If these two dynamic powers engage in mutual understanding and cooperation, many fundamental problems in Turkey will be solved.

According to Dogu Ergil, Öcalan's call "stems from the worry that the Gülen movement is a serious political rival and can work on the PKK's grassroots to cut off a large number of youths from the organization." ${ }^{\prime 49}$

As a reaction to Hizmet activism in slums, pro-Kurdish municipalities ${ }^{50}$ began opening Education Support Houses (Eğitim Destek Evleri) in 2006. Similar to the reading salons, the education houses are built in poor suburbs and provide free services. In the first year, the education house of Kayapınar Municipality - a major municipality in Diyarbakır - served 162 students; at the end of 2010, Kayapınar's five education houses reached 1,109 students. ${ }^{.1}$

Kurdish ethno-nationalists mobilize volunteer teachers affiliated with Eğitim-Sen, an educators' union with strong ties to the pro-Kurdish party.52 The programs are not solely focused on high school and university entrance exams; instead, the students are invited to participate in ethnic awareness activities such as Kurdish language classes, Kurdish music courses, Kurdish folk dance events, documentary film nights that are followed by group discussions, and seminars/lectures on Kurdish rights. ${ }^{53}$ Their sponsorship of

49 Ergil 2010.

$5^{0}$ The pro-Kurdish party mayors are in close contact with the PKK's city organization, known as the KCK (Koma Civaken Kurdistan), before being officially nominated, and after their election, the decisions of the municipalities are under scrutiny by the PKK movement. Turkish state authorities defined the KCK as a re-organization of the PKK in a broader vision in 2007, and therefore, as a terrorist organization (See KCK Law Indictment prepared by Turkish Republic's Public Prosecutor Diyarbakır Office, Indictment no: 2009/786). Inquisition of Osman Baydemir, mayor of Diyarbakır Metropolitan Municipality, by the KCK's underground court was a striking example that hit the news. See, Milliyet 2010.

$5^{1}$ KAYAPINAR 2006: 44, 2010: 18. Education houses that are located in Huzurevleri and 500 Evler were opened in 2007 and most recent ones were ready at the beginning of 2010.

52 Author's interview with Amed, the program coordinator of an education house in Kayapınar. Diyarbakır, July 18, 2009.

53 BAĞLAR 2010: 54-55. 
two- or three-week long summer schools where the students stay overnight is especially important in raising Kurdish ethnic awareness.

Competition in the education field attracted the attention of Hizbullah activists as well. The movement established two private exam prep centers in Bingöl and Diyarbakır. Yet, unlike its rivals, Hizbullah lacks well-educated activists in large numbers, and thus, it has serious constraints in terms of human resources. In my interviews, I learned that the group lacks some other resources as well: "In Diyarbakır, the governorship did not let us open reading salons; however, we were able to open them in Mersin and Adana," said Hasan. "We could not do it in Diyarbakır but the Gülen's association opened about twenty salons. How come? How does the State not let us?"54

\section{Namûsa Me Azadîya Me Ye: The Democratic Free Women's Movement}

"Women's organizations are so critical," said Welat as he spoke about various ethno-nationalist associations. "As the president says, 'Unless women are free, Kurds are captive'." The PKK leader Öcalan, referred to as the president, has placed special emphasis on women in his writings and teachings. Having Marxist and ethno-nationalist elements, the PKK ideology reconstructed "Kurdish women" through a utopian symbolism. In its early stages, the PKK narrated the enslavement of Kurds through images of captive women under tribal patriarchy. Since the early 1990s, the emancipation of Kurdish women has become a dominating discourse in the movement. In these depictions, free Kurdish women symbolized free Kurdistan, the motherland. ${ }^{55}$

The PKK's call for women's emancipation, however, is heavily colored with Marxist and socialist discourse. The ethno-nationalists' secularist policies regarding women appear radical in the Southeast, a highly conservative region. ${ }^{6}$ Islamic adoption of the headscarf, for example, is regarded as patriarchal and backward. Exposure of women's bodies in gender-mixed groups is valued and seen as a sign of independence. Among Kurdish Islamic circles, these secular features attracted harsh criticism, portraying the

54 Author's interview. Diyarbakır, July 25, 2009. Figure 5.1 indicates how resources play a significant role in the rivalry over education.

55 Çağlayan 2007: 87.

56 Handan Coşkun, coordinator of the Diyarbakır Metropolitan Municipality's Women's Problems Centre, maintains that the municipality's feminism-inspired progressive projects are not welcomed in public due to the conservative nature of the Kurdish society in general. See Coşkun 2006. 
PKK's Kurdish secularism as being as ominous as Ataturk's fervent Turkish secularism.

In my interview with Cemal, a Hizbullah activist, I got a sense of how gender politics plays a significant role in social movement competition:

The terrorist organization is foremost responsible for the cultural deterioration here. For instance, when they send two people out for their propaganda, they are often a boy and a girl. You often see their gender-mixed groups around. I mean, they try to normalize this (kind of socialization). Also the case for women's inappropriate clothes and promiscuity: they are the ones who lead this process. ${ }^{57}$

Referring to ethno-nationalists as "terrorists," Cemal believes that their emphasis on women's organizations is an insidious plot to transform Kurdish society. As expressed in Hizbullah's weekly, "If we investigate financial sources of women's shelters and various courses that have mushroomed in the region since the 1980 s - such as sewing, embroidery, hairdressing, carpet weaving, and cooking - we figure out that almost all of them are supported by imperialism's outreach institutions, i.e. Western missionaries, major Jewish foundations, and their local collaborators." ${ }^{8}$

Although Hizmet activists find Hizbullah's ideology rigid, they also believe that there is an agenda behind the ethno-nationalists' initiatives for women. Gülen-affiliated media claims that some leftist-secularist organizations systematically provide scholarship for Kurdish girls in order to sympathize with the PKK and to join pro-Kurdish party activism. ${ }^{59}$ Thus, as the argument goes, the Turkish radical left supports the PKK's secular identity over the bodies of Kurdish women.

Compared to Hizbullah, the Gülen movement's approach to women's issues is more liberal. Whereas Hizmet's women activists organize seminars to celebrate International Women's Day each year, Hizbullah perceives such events as Western imperialist projects. ${ }^{60}$ When it comes to representations of their movement, however, Hizmet activists are in line with Hizbullah's phronesis: they are reluctant to publicize women's issues in the region where a majority of the population is conservative. 
Hizmet's only association for women in Diyarbakır is not involved in women's rights issues; instead, it operates as an education-centered solidarity organization. Even the association's title, Sevgi Gülpembe Kadın Eğitim ve Dayanışma Derneği, includes both "women" and "education." A representative of the organization defines their goals as educating girls and women through activities such as seminars, reading and writing courses, and public lectures. ${ }^{61}$ The association undertakes various educational initiatives including state-sponsored projects such as the SODES (Social Support Program) project, Providing Self-Esteem to Children through Education.

Kurdish ethno-nationalist associations, on the other hand, are highly involved in women's issues by organizing mass demonstrations, rallies, and public lectures for women's economic, political, and sexual freedom. The associations organize annual celebrations and mass campaigns on March 8, International Women's Day, and November 25, the International Day for the Elimination of Violence against Women. Framing Kurdish women's issues globally, they attract funds from the European Union as well as local municipalities. Local women activists work in tandem with global Kurdish ethno-nationalist associations to enhance their influence. Two recent examples are the public hearing "A 2020 Perspective for Women in Turkey" organized in the European Parliament in 2010 and first Middle Eastern Women's Congress in 2013. Progressive actions of the pro-Kurdish party such as electing "co-chair" women for political posts are highly respected and supported by Turkish feminist organizations as well. ${ }^{62}$

Thus the field of women's organizations is not a heavily contested arena; instead, it becomes the ethno-nationalists' "turf" for niche building (Figure 5.2). As the PKK's legal activism grows, the women's associations have increasingly become the leading organizations of the movement, especially in Western Europe. ${ }^{63}$

One of the recent campaigns was titled Em jin in, ne namûsa tu kesîne, namûsa me azadiya me ye! (We're Women, not anyone's Honor. Our Honor is Our Freedom!), organized in twenty-eight cities in Turkey. The campaign defined freedom of Kurdish women in revolutionary terms, as exemplified in protest slogans that praise the PKK and its women guerilla fighters:

61 Author's interview. Diyarbakır, July 22, 2009.

62 Bianet 2014.

63 Berkowitz and Mügge 2014: 84; Casier 2010; ANF 2012. 
Figure 5.5 First Middle Eastern Women's Congress in Diyarbakır, organized by Kurdish women activists

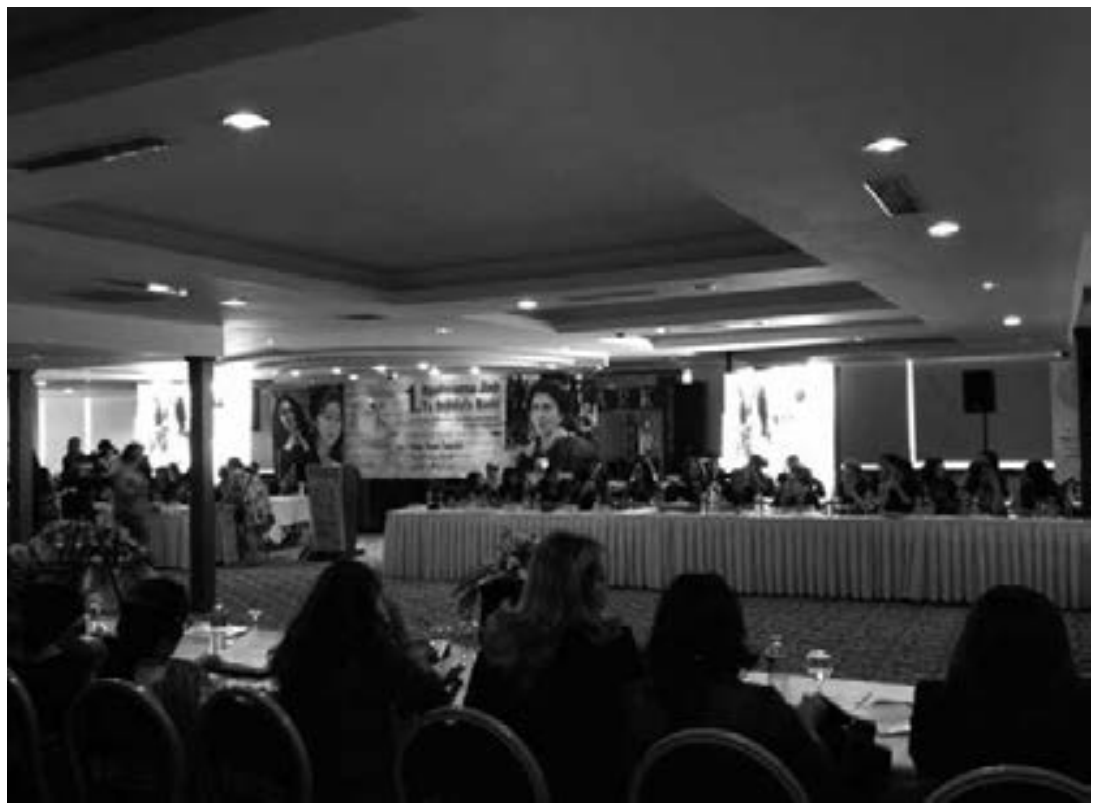

Photo by the author, June 1, 2013

"Beritanlaşın, Zilanlaşın, Özgürlüğe Yaklaşalım!” (Become like Beritan, ${ }^{64}$ Become like Zilan, ${ }^{6}$ so that we could approach Freedom!) and "Be Serok

64 As a woman guerilla, Gülnaz Karataş, alias Beritan, was a PKK militant who threw herself over a cliff when her ammunition ran out in the war between the PKK and the PDK (Kurdistan Democratic Party in Northern Iraq) in 1992.

65 Zeynep Kınacı, alias Zilan, is a highly significant figure - among the few who is annually commemorated by PKK activists. See, $A N F 2011$ b. Turning herself into a human bomb on June 30 1996, Zilan walked into a Turkish military parade in Dersim and ignited the bomb, killing around ten soldiers and seriously wounding another forty-four. Before taking this action, she wrote an open letter to Abdullah Öcalan. Below are excerpts from her letter that shed light on the psychology of a Kurdish fighter:

Dear President,

My name is Zeynep Kınacı. I was born in Malatya in 1972. My family comes from the village of Elmali. We belong to the Mamureki tribe. I studied tourism and psychology at Inonu University in Malatya. Before I joined the liberation movement, I worked at the state clinic in Malatya. I am married: my husband comes from the village of Xliya. He also went to the University of Malatya. During a clash in Adana, he was captured by the enemy in the winter of 1995. My family was fairly well off and I had a liberal upbringing. My interest in the left and Kurdish movement was aroused during my university studies, although at the time I was not attracted to any particular movement. 


\section{Jiyan Nabe" (Without the President No Life!). ${ }^{66}$ Some campaign slogans were on billboards in cities for several weeks and attracted reactions from some Islamist circles including Hizbullah. ${ }^{67}$}

I believe that my support for the PKK and the liberation movement had its roots in the fact that my family was concerned to preserve their Kurdish identity. We had a number of patriotic friends but we were not organized or anything like that. Also, the economic problems which beset my family prevented me from discovering my own identity for a long time. But slowly the situation changed, so that I was able to make a mature and confident decision to join the liberation movement. In 1994 Istarted to fight at the front in Adana for one year. In 1995, Ijoined the ARGK [Guerrilla] units in the Dersim region. It was at this time that I made a big development, both personally and politically... History shows that no national struggle can be victorious without a leader who devotes his life to the people, who feel its pains and its desires, who selflessly recognizes the practical tasks of the liberation struggle. A people who were totally alienated, whose political social and cultural values were exploited, posed a great challenge for the PKK leadership. Our party has started on the road to liberation under extremely difficult circumstances. Its attitude to religion, to questions of identity and the family are unique.

The arming of women and women's conferences and congresses have been organized by our party. The life of the party leadership, its courage, dedication to the cause, its intelligence, far-sightedness, its closeness and sensitivity to the ordinary people, its methods and experience is incomparable by the standard of any movement. Its interpretation and analysis of events is non-dogmatic...

At a time when the enemy is trying to achieve its aim by assassination attempts on our leader, this is the only response left. Such an action creates a siege situation for the enemy who lacks any moral grounds for their own action and is in a permanent state of confusion and crisis. It will show to friend and foe alike our total determination and preparedness to achieve our freedom, even at the price of our lives. Dear President,

I see myself as a candidate for a voluntary death. I willingly concede that to give our lives is, from the standpoint of your unending and tireless work for our liberation, not enough. I hope to be able to contribute much more than my life. Through your struggle you have succeeded in bringing our people to life. You are the guarantor of the Kurdish nation and a guardian of world humanism. Your life gives us love, courage and belief...

I consider this action as a duty. I am convinced that to overcome myweaknesses and the realisation of my freedom, this action has to be carried out. I want to follow the examples of our comrades, Mazlum, Kemal, Hayri, Ferhat, Bese, Beritan, Berivan and Ronahi...

I want to be part of the total expression of the liberation struggle of our people.

By exploding a bomb against my body I want to protest against the policies of imperialism which enslaves women and express my rage and become a symbol of resistance of Kurdish women.

Under the leadership of Apo, the national liberation struggle and the Kurdish people, will at last take its richly deserved place in the family of humanity.

My will to live is very strong. My desire is to have a fulfilled life through a strong action.

The reason for my actions is my love for human beings and for life!

Zilan (Zeynep Kınacı), 1996

66 ANF 2008; Ciwanenazad 2009. Kurdish ethno-nationalists call Abdullah Öcalan, the jailed leader of the PKK, the President (Başkan in Turkish, Serok in Kurdish), or more respectfully, Leadership (Önderlik) as if his persona has an institutional authority.

67 ILKHA 2ooga. 
In addition to high PKK symbolism, some public speeches during the campaign that explicitly condemned local Islamic culture in a secular leftist tone disturbed pro-Islamic Kurds. For example Leyla Zana, a prominent Kurdish women's activist and pro-Kurdish party deputy, maintained that Abdullah Öcalan is reminiscent of Atatürk in the sense that he has freed women from Islamic "feudal" culture. "In the contemporary age, the one who prioritized women in almost all fields in Turkey and Kurdistan is Abdullah Öcalan. Öcalan has said that freedom of women means freedom of society. Despite the fact of feudalism and increasing Islamization in Kurdistan, Öcalan created opportunities for women's leadership, and therefore, he is the contemporary Atatürk." ${ }^{18}$ Hizbullah activists harshly criticized these campaigns for women, perceiving them as symbolic attacks on religious Kurds. ${ }^{69}$

The concept namus (honor) strikes a loud chord among Kurds. İsmet, a leading Kurdish activist of the Gülen movement, narrates how he criticizes the PKK's recruitment of women in his local lectures:

In Van, there were about 3,00o people who came to listen to my seminar. During my talk, I asked them: "What kind of Kurds are you? A genuine Kurd is religious, a genuine Kurd is namuslu (one who protects his honor). What does it mean to send your daughters to the mountains, leaving them alone among males?"70

İsmet's talks seem to be effective among the conservative constituency. In the Gülen's women's association, a Kurdish mother told me that she would not let her daughter attend summer camps that are organized by proKurdish party municipalities. "I do not want her to be involved in politics," she added..$^{1}$ An independent observer claims that these summer camps for school children become an opportunity for Kurdish ethno-nationalists to recruit youngsters for the movement. In general knowledge quizzes, children are asked the names of guerilla martyrs such as Zilan and Delila. ${ }^{72}$

68 Hürseda 2009.

69 Doğru Haber 2009.

70 He narrated this story in his public lecture to Gülen activists in the United States. I shadowed the meeting. New Jersey, December 26, 2009. For a conceptual analysis of the politics of sexuality and the public image of guerillas, see Goodwin 1997.

71 Author's interview, Diyarbakır. July 22, 2009.

72 Author's interview, Diyarbakır. July 21, 2009. Delila was a PKK woman fighter who was singled out for her outstanding voice. She died on August 23, 2007, in a clash with the Turkish 
Figure 5.6 A wall in the Arjin Youth Center, founded and funded by Yenişehir Municipality in Diyarbakır. The picture of Delila, a woman guerilla "martyr," with a Kurdish poem

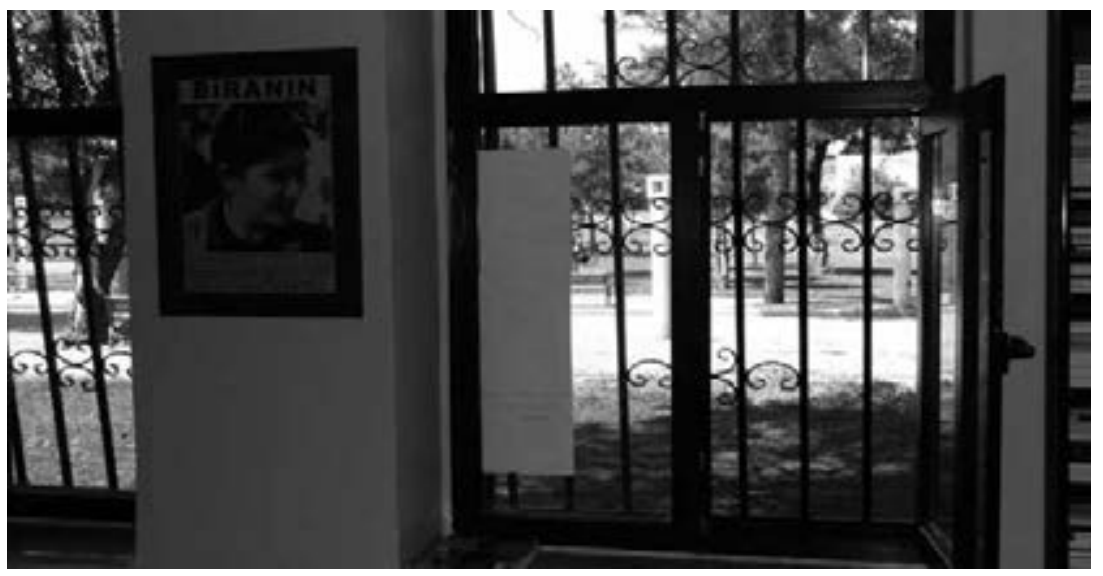

Photo by the author, July 21, 2009

Having attended these summer camps as a student, Zelal thinks that she has been enlightened. Zelal now volunteers for a pro-Kurdish party as a member of the youth council and helps five younger students in their studies. "It's not so important that they pass their exams," she said. "What really matters is to get these students' hearts and minds."73 Zelal's friend in the youth council emphasized how "organized youth" (örgütlü gençlik) are enlightened, "unlike youth of the system." ${ }^{74}$ Women guerilla fighters in the defense of Kobane against Daesh (ISIL) got the attention of Western media in a positive light, providing a boost to similar feelings among Kurdish youngsters. The PKK's secular women image was presented as an alternative to Daesh's horrible attacks in the name of Islam.

Founded after 2007, the youth centers are supported by the pro-Kurdish party municipalities and work closely with the women's wing of the ethno-nationalist movement. As an activist who works at a women's house, houses which are also funded by the municipalities, Feride points out the importance of their organized action that unites all associations and houses. "We, as women's organizations, have an organized body within the Kurdish

military in Roboski/Uludere. Her songs are still circulated on YouTube: https://www.youtube. com/watch?v=fNJYoEtZFQE

73 Author's interview, Diyarbakır. July 18, 2009.

74 Author's interview, Diyarbakır. Julyı8, 2009. 
Figure 5.7 The Roboski (Uludere) monument in Diyarbakır

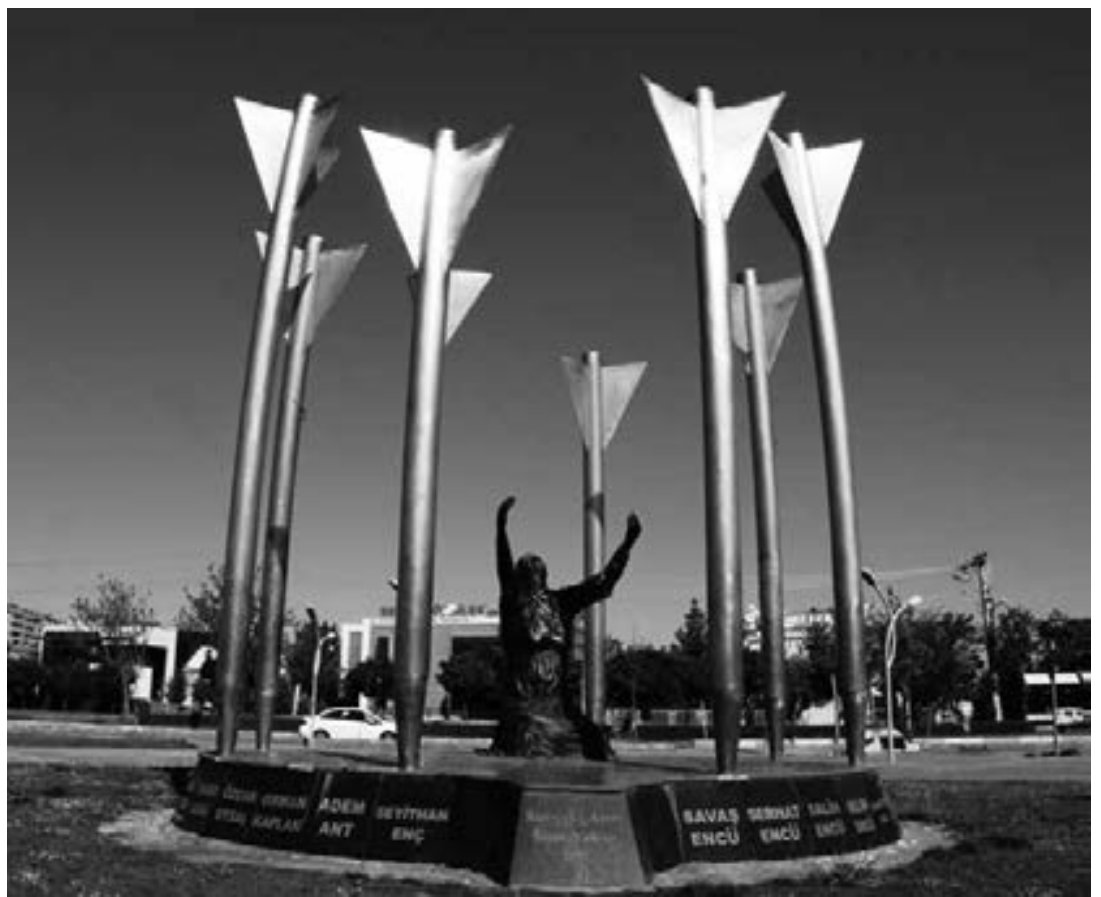

Courtesy of photojournalist İsmail Avcı

(c) İsmail Avcı

movement. All those who are working for women's institutions are united under the title of Democratic Free Women's Movement. This type of organized body, of course, brings great benefits. ${ }^{75}$

In our conversation, Feride frequently underlined state violence and how women are mobilized to protest it. "Violence within the family often becomes secondary," she remarked. "These women ask how they could file a complaint about their family members when those who should solve these very issues [i.e. the State officials] are in fact murderers of these women's spouses or sons." In this regard, Feride aims to challenge mainstream stigmatization of the PKK members and their families. Deceased PKK members should be perceived as victims of State violence; instead, the mainstream discourse portrays them as PKK rebels or "terrorists" who are "wiped out"

75 Author's interview, Diyarbakır. July 16, 2009. The PKK also formed an armed umbrella organization for women, Kurdistan Women's Freedom Party, Partiya Azadiya Jinen Kurdistane, in 2004. 
by the authorities ${ }^{76}$ Through this frame, the women's organizations aim to challenge the dominant political discourse by depicting women $v$ s. the state and mothers vs. the state.

Kurdish women activists join with the larger leftist activism to force the Turkish State to face its dirty years. Reminiscent of the Mothers of the Disappeared in Argentina, ${ }^{77}$ afflicted Kurdish mothers are mobilized to make sit-in protests on Saturdays each week. Most "Saturday mothers" - as people call them - lost their children during the martial law era when the Turkish Armed Forces frequently interrogated alleged PKK sympathizers in the region.

The symbolism of "mothers" has proven to be quite powerful emotionally: when making a declaration of peace talks with the PKK, known as "Kurdish Opening," then- Prime Minister Recep Tayyip Erdoğan frequently said, "Let mothers not cry anymore!" Later, in 2011, Erdoğan accepted a group of "Saturday mothers" in his office, promising that the government would help find the perpetrators and bring them to justice.

As the Kurdish Opening failed and violence escalated between the Turkish State and the PKK, the mothers vs. the state framing was utilized more often by the ethno-nationalist activists. For example, the pro-Kurdish party recently erected a statue of a howling Kurdish mother under attack in memory of the Roboski incident when Turkish jets fired on a group of Kurdish smugglers and killed thirty-four civilians, acting on the information that PKK militants were crossing the border. At the opening of the Roboski monument in December 2013, the Kurdish women activists criticized the prime minister, pointing out that poor mothers are still crying due to military operations..$^{8}$

\section{Religious Public Symbolism: Hizbullah Finds Its Niche}

Public and religious. These two words capture Hizbullah's civil society activism in the region. Hizbullah activists not only have resources but

${ }_{7} 6$ The issue of collective violence (whether state violence or PKK violence) is quite controversial because of the illegal state operations -what is popularly known as "deep state"- during the dirty war years in the 1990s. The Turkish general public, for example, interpreted Bloody Newroz in 1992 (where at least seventy people were killed, 150 wounded) as an act of PKK terrorism; whereas Kurdish public opinion strongly believed that it was an example of indiscriminate state violence against the Kurds (Akçura 2009: 228-38). More recently, scholars have noted the role of para-military groups operated under the name of JITEM (Gendarmerie Intelligence and Anti-Terror Struggle), an illegal unit within the Turkish Armed Forces, in provoking tensions under the martial law (Kaya 2009). For details, see chapter 8.

77 For details of the Argentina case, see Kurtz 2010.

78 DIHA 2014. 
also an ideological commitment to be highly active in the field of religious institutions. One would also expect the Gülen movement to be an active competitor in this field because of its Islamic ideology; yet, as noted earlier, Gülen activists' phronesis, the way they conduct their educational activism, is quite different. They consciously avoid presenting themselves through religious associations. On the other hand, Kurdish ethno-nationalists' Marxist roots have been an ideological barrier for them regarding public symbolism of religious identity. Thus, the field of religious institutions has become a natural and uncontested space for the Hizbullah activists to build their niches (Figure 5.8).

All Hizbullah-affiliated associations in Turkey are gathered under an umbrella organization named Platform for Lovers of the Prophet $(P e-$ ygamber Sevdalıları Platformu). There are also sub-platforms under the main one, such as the Platform for Prayer Volunteers (Namaz Gönüllüleri Platformu) and the Platform for Understanding the Quran (Kur'anı Anlama Platformu). ${ }^{79}$ The titles of the organizations themselves indicate Hizbullah's willingness to represent Islamic identity in public. Organizational names are indeed "an effective lens through which to study collective identity" because naming organizations is a part of the identity construction process and boundary work. ${ }^{80}$

The Platform's most effective events are annual public celebrations during the week of the Prophet Muhammad's birthday (according to the lunar calendar). Unlike numerous Islamic celebrations in small congregations, Hizbullah is the only movement that gathers hundreds of thousands in city centers for public rallies. In 2006, the movement's organization of a mass rally in Diyarbakir to protest the Danish cartoons that insulted the Prophet drew about half a million Kurds, and this particular event triggered the annual meetings for the Prophet. ${ }^{{ }_{1}}$ Annual rallies are held in twenty-five cities and sixty-five districts all over Turkey. ${ }^{{ }_{2}}$ These mass gatherings are particularly important for Hizbullah activists because of their constant public stigmatization as "terrorists" in the Turkish media.

The celebrations have a dual function and target both activists and the public. For the activists themselves, the gatherings are clear indications

79 The Mustazaf-Der recently announced that a new platform is under progress to initiate a campaign for hijab (Tesettür Seferberliği). See, Doğru Haber 2011.

8o Ghaziani 2011: 106.

81 The Platform also organized mass rallies for Gaza and Palestine to protest Israel's three week bombing and invasion of the Gaza Strip in early 2009.

82 The information is received from Mustazaf-Der website declarations: http://www. mustazafder.org/bildiriler.asp Accessed July 10, 2011. 
Figure 5.8 Number of Associations in city of Diyarbakır in 2011

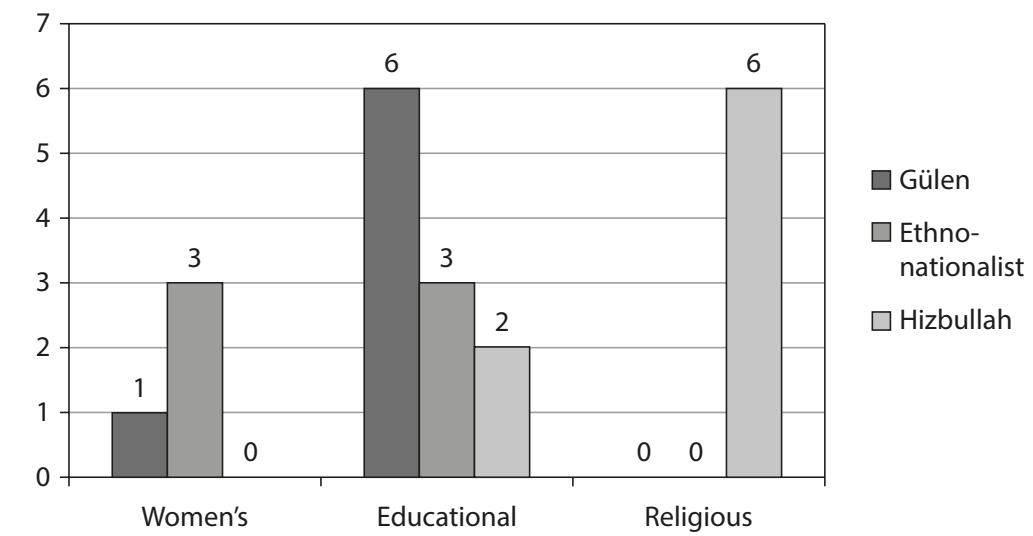

Source: Diyarbakır Provincial Directorate of Associations

of popular support, and therefore provide a bright future prospect; for the public, these peaceful celebrations around the most unifying figure, i.e. the Prophet, are a sign of moderate Islam instead of radicalism. "From now on," wrote a leading activist after a mass gathering in Diyarbakır, "when one utters the word Diyarbakır, the first thing that comes to peoples' minds would be Diyar-1 Muhammad (city of Muhammad), Diyar-1 Islam (city of Islam), and Diyar-1 Iman (city of Belief) ... This is not only an incredibly unbelievable event in terms of participant numbers but also in terms of quality in dedication, belief, and ecstasy." ${ }^{3}$

Strategically, the Platform's celebrations aim to suppress the movement's differences from the majority and therefore gain public legitimacy. Organizing each annual celebration makes them more united within the group because of the collective work for preparations months before. ${ }^{84}$ Hizbullah's celebrations, however, were also successful in drawing many outsiders among Kurds. ${ }^{85}$ In 2014, years after in-group debates, Kurdish ethno-nationalists decided to organize their own celebrations for the

83 Göktaş 2009 .

84 For celebration and suppression strategies of social movements, see Bernstein 1997. For collective identity making through public symbolism, see Ghaziani's (2008) analysis on LGBT marches to Washington, DC.

85 Hizbullah also started to organize public essay contests and exams about the Prophet's life, knowing that similar exams and consequent award ceremonies are conducted by Gülen activists. See, ILKHA 2014. 
Figure 5.9 Annual celebration of the Prophet's birthday, organized by Hizbullah activists, April 19, 2015

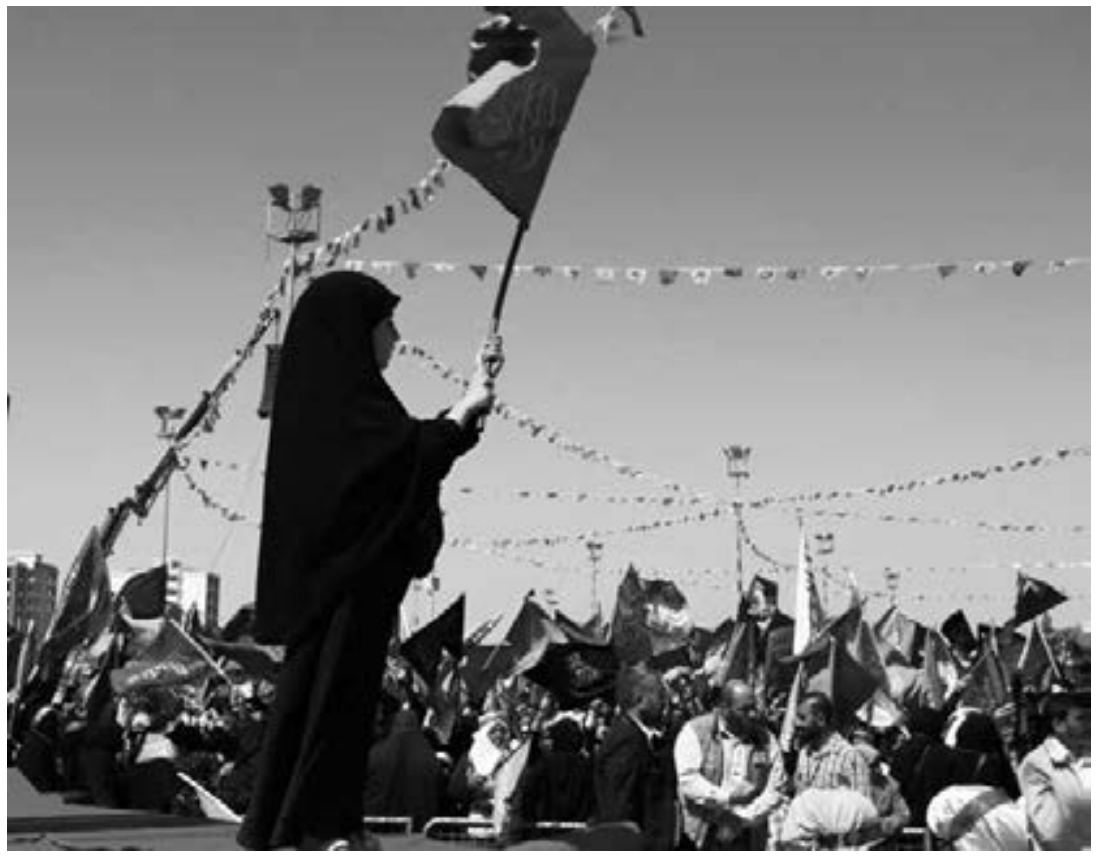

Courtesy of photojournalist İsmail Avcı (c) İsmail Avcı

Prophet, advising their larger constituency not to attend Hizbullah events. ${ }^{86}$

In 2010, Hizbullah activists put another annual public event in their agenda: memorial meetings for Sheikh Said, a prominent Kurdish religious leader who revolted against Ataturk's secularist regime in 1925. Having both ethnic and religious sentiments, Sheikh Said's rebellion is considered as the first mass revolt against the modern Turkish Republic. The young Turkish State hanged Sheikh Said and his friends in Dağkapı Square, a famous square in the center of Diyarbakır. Their request for an official permit to hold a public meeting in Dağkapı Square for the eighty-sixth anniversary of the execution was denied. The following year, thousands of Hizbullah activists gathered in another public square, Batıkent Meydanı, and chanted slogans such as, "God is Greatest!”, “Sheikh Said, the Guide!”, and “Long Live Hellfire for Tyrants!". Hizbullah leaders gave speeches 
in both Kurdish and Turkish, criticizing secularist as well as nationalist policies of the State.

Hizbullah's symbolic claim of Sheikh Said has attracted criticism from the Sheikh Said family. One of the grandsons of Sheikh Said explained to me in detail:

Hizbullah is a modernist movement. I mean, it is a movement that tries to shape the society in accordance with a top-down project, which conflicts with the society's nature ... It is a movement against the Tarikats (Sufi Orders) and tradition. Yet, among the conservative Kurds, tradition and the Sufi orders are extremely powerful ... In the month of Ramadan and Eid Celebrations, the majority of the religious Kurds go to the tombs. They rush to visit the graves of their Sheikhs or the tombs of Companions of the Prophet. What did Hizbullah say: These practices are pagan rituals; it is Shirk (polytheism). Many times, in funeral gatherings and other instances, I witnessed that the people's hearts were broken as they (Hizbullah followers) expressed these ideas. Moreover, the conservative Kurds also have nationalist feelings ... Hizbullah's stance had never been close to this standpoint either. ${ }^{87}$

Nonetheless, Hizbullah's annual mass organizations have become worrisome for the ethno-nationalist camp. In 2012, only a year later, the proKurdish party organized a gathering in Dağkapı Square in memorial of Sheikh Said's execution. Kurdish ethno-nationalists hinted that they will make similar memorial events for Sheikh Said each year. ${ }^{88}$

\section{Civic Activism and Conflict Transformation}

Competitor civil society organizations are producers as well as products of an emerging inter-movement relationship in the region. For the first time in Turkey's modern history, Kurdish civic sphere has become vivid, ushering in a new era after a long brutal war under martial law. Rival activists not only win the support of the local Kurds but also gain legitimate public voice through charity activism. The absence of a social movement in charity activism would mean a sign of indifference to the problems of the local

87 The author's interview with Muhammet Akar. Diyarbakır, July 9, 2009.

88 See the declaration at Sur Municipality's website: http://sur.bel.tr/turkce/?p=3280 Accessed May 21, 2014. 
population, and therefore, a lack of voice on behalf of Kurds. Thus, social movement resemblance in charity activism becomes an institutionalized norm. In the words of Fligstein and McAdam, skilled social movement activists "will engage in moves that they hope will preserve or improve their position in the existing SAF [strategic action field]. These constant adjustments constitute a form of organizational learning." ${ }^{89}$

On the other hand, rival movements invest in different types of associations and organizations, crafting their niche fields. These specific fields, however, should be seen in the larger field of Kurdish civil society in order to understand relational dynamics. The very fact that pro-Islamic actors are not strong players in the field of women's organizations is significant in explaining niche activism of Kurdish ethno-nationalists. These moves of rival activists to engage "in" or "out" of a field are relational strategic choices, and consequently further reproduce an emerging culture of competition. Thus, when we think about the factors that shape field construction, i.e. resources, ideology, and phronesis, we need to be aware that these factors are not static; they are also in transformation through emerging social relations.

A surprising informal comment by Welat, who spent a few days with me to help in conducting interviews with various ethno-nationalist organizations, is enlightening here. Having served more than a year in prison, Welat is a neighborhood leader, mahalle eşbaşkanı, of Koma Civaken Kurdistan (Union of Communities in Kurdistan), PKK's umbrella organization in metropolitan cities. "The most difficult issue for us is religion," he said. "If, let's say, two members of a family save themselves from religion, five others are still trapped."

I knew that Welat would not make such comments in a formal interview, so I listened to him carefully. "Kurds are the ones who have been most exploited by Islam, but interestingly, they are also the ones who embrace Islam in the most serious way." Welat narrated how Diyarbakır was captured by Islamic forces in the $7^{\text {th }}$ century and colonized for centuries. He concluded, "We do not discuss these things any more. That is the solution to this problem." In another instance, Welat's friend Awaz commented informally, "Religion is the opium of the people." ${ }^{\circ}$

Pro-Islamic actors' rising activism, however, pushed Welat and others into coming to terms with religion at a rapid pace. As the next chapter thoroughly describes, the PKK's ideological stance has started to change

89 Fligstein and McAdam 2011: 14.

90 Author's personal communication. Diyarbakır, July 17, 2009. 
as ethno-nationalists become active in defining "Kurdish Islam" in various platforms. A relational framework, therefore, is needed to capture ideological transformation and behavioral moderation. As competitor Kurdish activists perceive each other as "rivals" through civic activism, they have become localized by moderating their stances. Activists' localization has been strengthened in symbolic battles to contest authenticity of being genuine Kurds. In what follows, I examine how the PKK has become engaged in defining Kurdish Islam while Hizbullah has discovered the Kurdish language through symbolic localization. 



\title{
6 Going Native
}

\author{
Contesting Kurdish Islam
}

The most brutal relations of force are always simultaneously symbolic relations.

- Pierre Bourdieu

In the summer of 2007, a group of Kurdish patriots came together to set up a religious association for the first time in their lives. Ciwan overshadowed the meetings and helped them to complete official paperwork. As an outsider, he promptly recognized larger strategic changes within the ethno-nationalist movement. In Ciwan's words, "The DTP [pro-Kurdish party] started to build an unprecedented relationship with some retired imams, reserving one delegate place for representation of Islamic leaders in its major platform [the Democratic Society Congress]."1

A few months later, the association was established in the largest Kurdish city, Diyarbakır. The branches of DİAYDER, Din Adamları Yardımlaşma ve Dayanışma Derneği (Religious Leaders' Assistance and Solidarity Association) rapidly mushroomed in other Kurdish-populated cities in Turkey such as Van, Hakkari, and Şırnak as well as the major cities that witnessed massive Kurdish migration, including İstanbul, Mersin, Adana, and İzmir.

In its first public statement, DİAYDER's İstanbul branch revealed the dynamics of rivalry to win the hearts and minds of the Kurds:

We want to save our youth from the Fethullah Gülen community ... Our young people come to İstanbul and fall into traps of Fethullah Gülen or MHP [Nationalist Action Party] or some other Islamic parties. We would like to save our youth from these groups by educating them. ${ }^{2}$

Explicit recognition of major Islamic movements was also evident in my conversations with DİAYDER imams. I asked Ahmet Bey, founder and honorary president of the Association, the reason for building such a religious organization for an ethno-nationalist cause. "We established this Association to serve all the people living in Diyarbakır," replied Ahmet Bey.

2 Özgür Gündem 2008. 
We practice the right Islam, not having any relation with any Sheikh or any sect. Look at Fethullah Gülen ... Now, he is all over the world today; and yet, I believe, many of his actions distort the Quran. Nowadays, many sheiks and (religious) leaders seek material benefit solely. That's what you will never see in DİAYDER. ${ }^{3}$

Although I never asked about Fethullah Gülen and his movement, Ahmet Bey's reference to the Gülen movement was remarkable. The subtext of the quote alone indicates that the ethno-nationalist imam organization DİAYDER has attempted to challenge its pro-Islamic "rivals" in the region, namely Hizbullah and the Gülen movement, through claims to represent authentic Kurdish Islam.

Recently, the Kurdish ethno-nationalists' growing interest in religious public symbolism has introduced a hybrid pro-Kurdish identity that has both Marxist and Islamic roots. Challenges, however, abound. An urban pro-Kurdish activist in Ankara succinctly summarized the logic of transformation in our conversation: "Employing a Marxist discourse in the region is like dancing without music. The Southeast is extremely conservative."

In this chapter, I explore how Kurdish ethno-nationalists strategically pursue what I term symbolic localization in harmonizing ideology and pragmatic politics. Symbolic localization refers to a discursive process of collective reputation work in which social movement activists blend local cultural repertoires and their "we" identity in order to build recognition, legitimacy, and prestige in the eyes of the local population. Thus, it enables activists to refine and shape their ideology over time due to its "relational" character: meaning is constructed through strategic relations with competitor Kurdish activists.

\section{Revolutionary Ideology as a Discursive Process}

Scholars have long emphasized the difficulty of studying ideology. Ideology is a "muddy river," as Clifford Geertz suggests, and it is perhaps "the most elusive concept in the whole of social science." In social movement studies, ideology is a "cluster concept," referring to "a relatively stable and coherent set of values, beliefs, and goals associated with a movement or a broader,

3 Author's interview, Diyarbakır, July 22, 2009.

4 Author's personal communication, Ankara, June 23, 2009.

5 McLellan 1986: 1. 
encompassing social entity." Although the post-Cold War era signaled a "cultural turn" in social movement studies, the concept of ideology did not receive much attention due to its "pejorative legacy" in classical Marxist approaches. ${ }^{7}$ In the words of a leading scholar,

The problem is that most treatments of social movements that accent the influence of ideology rarely unpack and elaborate the character of ideology or how it is used and affects the ebb and flow of movement activity. Instead, the concept is typically applied or asserted in too blunt a fashion, as when it is claimed that social movement activity is ideologically structured, social movement participants are ideologically driven or subscribe to the same set of beliefs and ideas, or that collective action frames are simply derived from an extant ideology or existing cultural stock.

David Snow's criticism is clearly directed at the classical social movement theorists who argue that activists are strongly resistant to arguments, evidence, and larger social forces that challenge their ideologies. ${ }^{8}$

Paying less attention to movement ideologies, social movement scholars developed framing analysis to study change in activists' cultural repertoires. ${ }^{9}$ While the framing approach is quite useful in articulating the processes of strategic performances by activists in the heat of contention, its "focus on calculation and persuasion" overshadows how "activists are constrained by the discursive fields they are trying to manipulate. ${ }^{10}$ As Robert Benford argues, "underlying the descriptive bias in the movement framing literature is the tendency to focus on frames as 'things' rather than on the dynamic processes associated with their social construction, negotiation, contestation, and transformation." ${ }^{\prime 1}$

Following Marc Steinberg, I regard ideology as a discursive process. ${ }^{12}$ I argue that ideologies are always in transformation through social movement discourses, and so the task left to the researcher is to unpack these discursive processes in order to capture social change. Pointing out this void in the literature, Pamela Oliver and Hank Johnston note that "less has

6 Sartori 1969: 398. Snow 2004: 396.

7 Oliver and Johnston 2000: 42.

8 Snow 2004: 397. See, for example, Turner and Killian 1972: 249; Wilson 1973: 108-24.

9 Snow et al. 1986; Benford and Snow 2000.

10 Steinberg 1999: 742; Jansen 2007: 957.

11 Benford 1997: 415.

12 Steinberg 1993 . 
been written about the processes that occur when a group of committed activists reconstructs their ideology. ${ }^{13}$ To fill the void, we may consider ideologies as discursive processes in which activists' mundane theories about the social world are judged, evaluated, discussed, and transformed. This dynamic view of ideology in action is best reflected in the scholarship of the dialogic perspective to social sciences. ${ }^{14}$

Proponents of the dialogic perspective regard the domain of ideology in relation to the domain of signs and semiotic practices. It is through discourses that social movement activists "identify and locate themselves in the matrix of relationships and institutions of their social world"; therefore, activists' discourses are often "reflexive with these relationships and institutions. ${ }^{\prime 15}$ In this sense, discourses are contextually dependent forms of action, and so are ideologies. Ideologies take shape under historical/ contextual circumstances, and they operate through shifting discourses that are deeply embedded in social relations. As Steinberg argues,

From a dialogic perspective the analysis of ideology centers on discursive domination and resistance, hegemony and counterhegemony ... Because of this emphasis on domination and resistance, we analyze ideologies most appropriately in essentially relational terms ... (A) dialogic model depicts ideologies as always somewhat disorderly in their structures and fundamentally multivocal in their potential for producing meaning; they have no inherent systematicity ... The flux and multiplicity of meaning are due to both the very constitution of the signifying practices through which they are produced and to the relationships between the many formations available to actors. ${ }^{16}$

In such a relational sociology perspective, ideologies are neither blinkers that are put on by activists nor what Karl Marx called the "nightmare weighing on the brain of the living"; instead, they are shaped and transformed in social relations through semiotic practices. ${ }^{17}$ "Ideology," maintained Gerald Platt and Rhys Williams, "is an assemblage of ideas about the construction of activities and circumstances oriented to achieve interests and life

16 Ibid., p. 317.

17 Marx 1978: 21. 
experiences." Thus, it is "a structurally grounded local construction ... expressed in language discourse that orients moral, cognitive, and emotive process." ${ }^{18}$

As I illustrate in the following pages, PKK activists articulate their worldviews in a relational manner. Activists' consciousness of the "other" strongly shapes their discourse, which in turn leads to a reproduction and revision of the group ideology. In the words of Marc Steinberg, the "dynamic differentiation and complexity of an ideological formation result from a continual negotiation of meanings with formations used by others." This ideological formation generally offers "meanings that conflict with one another." ${ }^{\text {19 }}$ Charles Tilly's notion of "repertoires of contention" grasps the nature of social relations here. "Repertoires," wrote Tilly, "do not descend from abstract philosophy or take shape as a result of political propaganda; they emerge from struggle. ${ }^{20}$

\section{The Kurdish Ethno-Nationalist Movement, Islamic Identity, and Symbolic Localization}

Similar to many leftist revolutionary organizations, the PKK has put a special emphasis on ideology formation. "If you break the link between yourself and your ideology," said the PKK's leader, Abdullah Öcalan, in his lecture to Kurdish revolutionaries, "you will bestialize." His essay entitled "Persistence on Socialism means Persistence on Becoming Human" further calls for commitment to the PKK's ideology:

Instead of saying "our people are ignorant, thoughtless" which is repeated in abundance by everybody, we will in general say: Our people are ideology-less, without morals, and they have descended to the level of bestiality because they have been deprived of these basic concepts ... If I were to become a great voice, the most fundamental cause of this would be improving myself ideologically. ${ }^{21}$

Having strong socialist and Marxist elements, however, the PKK-led Kurdish ethno-nationalist movement has ideologically been at odds with the 
traditional culture of local Kurds who are predominantly Sunni Muslims. ${ }^{22}$ In this sense, the PKK insurgency has fostered "a dual rebellion - against both the traditional structure of Kurdish society and the Kemalist state system., ${ }^{23}$

The guerillas regarded the traditional culture as a pacifying social force that made Kurds obedient to the Turkish authorities. Öcalan long emphasized that Sunni Islam played a strong role in maintaining the enslavement of Kurds. In the early PKK discourse, Zoroastrianism is the "genuine" religion of the Kurdish nation since Islam was introduced by "colonial" powers. ${ }^{24}$

In recent years, however, the PKK movement has had to come to terms with its traditional rigid stance as the movement's goal is to win the hearts and minds of local Kurds. In the words of a deputy of the pro-Kurdish party, "We've had some problem with religion in the past because of the party's Marxist origins. We were once more ideological, but we are becoming more a party of people, a party that is respectful of everyone's views.".25

In fact, the first time the PKK changed its hostile language against Islam was in the early 1990s. The PKK formed the Union of Kurdistan Pious People in its fourth congress on December $261990 .{ }^{26}$ These developments, however, were not effective in bringing about an ideological transformation of the PKK since the secularist discourse was quite powerful within the movement during the 1990s.

The AKP's success in drawing Kurdish votes, especially in the 2007 election, has made Kurdish ethno-nationalists increasingly concerned about Turkish-Islamic activism, especially the Gülen movement, in the region. As another pro-Kurdish party deputy states,

We are not against the religion, but the Gülen community, which has been systematically supported in the Southeast by the dark powers, pursuing an organized effort to develop Turkish-Islamic synthesis. Their aim is to transform Kurdish society in accordance with the understanding of Turkish-Islam. The Gülen community is trying to form its own Kurds. ${ }^{27}$

22 From the 1970s onward, pro-Kurdish leftist organizations have relied on Marxist interpretations of religion and society. As Van Bruinessen (2004) notes, among a dozen different Kurdish political associations and underground parties in the 1970s, the majority of them were combining nationalism with some type of Marxism. All of these groups had their major support among university students as well as the educated urban stratum, and they were very explicit in their denunciation of the traditional Islamic culture that prevails in Kurdish-populated regions.

23 Yavuz and Özcan 2006: 106.

24 Öcalan 2003: 18; Bender 1991: 71-76; Izady 1992: 136.

25 CSM 2009.

26 Çevik 2012: 96.

27 Haber24 2009. 
Threatened by the pro-Islamic AKP's electoral success in 2007, the Kurdish ethno-nationalists have started to construct a new public image that is at peace with Islam. A few examples include Kurdish imams' public speeches in the pro-Kurdish party rallies, Abdullah Öcalan's request for the establishment of a religious science academy in Urfa, the recitations of Mevlid - commemoration of the Prophet - in funeral ceremonies of PKK fighters, and public recognition of women guerillas who wear headscarves. ${ }^{28}$

According to the observations of a Kurdish journalist, the ethno-nationalists' everyday interaction with local Kurds increasingly includes Islamic vocabulary, i.e., Selamun Aleyküm, Inşaallah, Maşallah etc., especially after the 2007 electoral defeat. ${ }^{29}$ Engagement with the Islamic repertoires also includes slogans in the ethno-nationalist rallies. In a public rally in Suruç, for example, activists shouted "Ya Allah, Bismillah, Seroke me Abdullah!" (O God, In the name of God, Our President is Abdullah). ${ }^{30}$

In Turkish media, the pragmatic utilization of Islamic discourse is often depicted as an insidious and cynical attempt by the PKK. The pro-Islamic AKP began to denounce the PKK as a defender of Zoroastrianism for the Kurds. $^{31}$

And yet how were these aforementioned strategic changes perceived by the Kurdish leftist revolutionaries? In what follows, I demonstrate that the PKK's ideology was refined to embrace Kurdish Islamic repertoires through the symbolic localization process, a process in which Kurdish activists gradually introduced local Islamic discourses and have constructed their own Kurdish-Islamic perspective in a dialectical opposition to Turkish-Islamic discourses. Therefore, symbolic localization enabled the PKK movement to come to terms with its traditional ideology and reconstruct ideology through discursive battles with its rivals in the region, namely the AKP and the Gülen movement. The Kurdish ethno-nationalists employed three mechanisms for symbolic localization: moral authority building, public symbolism, and memory work.

\section{Moral Authority Building}

The PKK activists aimed to gain the support of local Kurdish leaders by forming alliances with religious authority figures. Murat Karayılan, the PKK commander, publicly visited a significant Naqshbandi sheikh, Sheikh 
Şebendi, a few weeks before the general election in 2011. Such a symbolic performance was enough to encourage some Naqshbandi sheikhs to call all Kurds to support the pro-Kurdish party candidates. ${ }^{32}$ Moreover, proKurdish municipalities began to organize dinner receptions with Islamic community leaders from diverse backgrounds.

The formation of an organization for imams, Din Adamları Yardımlaşma ve Dayanışma Derneği (DİAYDER), was the most radical step for Kurdish ethno-nationalists. I was surprised to learn of these imams' deep-rooted connection with Turkey's left. Ahmet Bey is one of them:

I personally know the ' 68 generation though I was very young at the time ... Frankly speaking, we were leftist folks. Although I had a madrasa (Islamic religious schools) education, we were among the extreme leftists ... We were following the steps of Deniz Gezmiş and his fellows ... In 1976, I visited Cumhuriyet's [flagship leftist newspaper in Turkey] headquarters in Istanbul to subscribe to the daily. Every day I was getting my daily newspaper as well as a number of ideological periodicals until the beginning of the Kurdistan Freedom Movement. Only then did I stop reading Cumhuriyet. ${ }^{33}$

Although it is unusual to hear these stories from an imam, Ahmet Bey's life trajectory is typical of a Kurdish ethno-nationalist activist story: active participation in leftist movements in the 1970s and an experience of ethnic identity consciousness in the 1980s. His religious educational background's engagement with Marxist revolutionary views enabled him to develop a peculiar combination of leftist ideals and an Islamic perspective: "I believe that someone who joins the Kurdish political movement should not say 'I'm a right-wing conservative or leftist or pro-Sharia [i.e., Islamic law] or pro-religion'; instead, (it should be as follows) 'I'm an oppressed one, and, I would like to have a decent life like anybody else."

Another imam, who interrupted our conversation as Ahmet Bey stood up to greet him because of his age and scholarly knowledge, maintained that an ethno-nationalist worldview can accord with Islam:

One of our friends, Mele Abdullah, once said, "There is no way to establish Kurdistan (i.e., an independent Kurdish state)." We reacted: "O Seyda! Why are you talking like this!” He responded: "It's because only Kurds 
remained in Allah's hands! All others gave up the religion except Kurds." This is true: After converting to Islam, Kurds have always prioritized their religious identity. Although they have had an ethnic consciousness, it has always been a secondary issue ... Yet our Prophet says, "Whoever is killed while he/she is seeking his/her rights (against injustices), he/she is a martyr." I mean, our Prophet never ever said "always seek the hereafter!”. In fact, God says, "thou shalt not forget this world." But Kurds have forgotten the world! On the other hand, our (Islamic) brothers - Turks, Arabs, and Iranians - have never shown us mercy.

As reflected in their answers to my questions, the imams tend to amalgamate Islamic knowledge and a Marxist nationalist discourse. The master imam's remark on being a martyr was a clear reference to the PKK guerillas who died in their fight against the Turkish state.

In their activism, however, the ethno-nationalist imams are not only becoming involved in framing efforts to combine Islamic theology with local Kurdish cultural repertoires, but they also aim to construct their moral authority among Kurds. Anthropological studies note that Islamic authority making is facilitated through controlling the boundaries of religious knowledge and the social boundaries of community. ${ }^{34}$ My informants frequently emphasized that all members of the Association graduated from madrasa.

Rooted in medieval Islamic society, the madrasa system goes back to eleventh-century Baghdad. It soon after emerged in Kurdish-populated cities in Southeastern Anatolia. The madrasas were local schools that provided not only education in Islamic jurisprudence $(f i q h)$ but also in philosophy, logic, and the rational disciplines. The madrasa system had been influential in Kurdish society until the foundation of the modern Turkish Republic. After enactment of the 1924 law that standardized the education system (Tevhid-i Tedrisat Kanunu), all traditional madrasas were officially banned. Since the madrasa system has been crucial in preserving Kurdish national consciousness, scholars interpret these forced closures as a part of an assimilation project of the modern Turkish state. ${ }^{35}$ Despite the official ban, the madrasa system in Kurdish towns has survived by underground local support..$^{6}$

As graduates of the madrasa system, the DIAYYDE imams are highly respected in local Kurdish communities. Feeling of belonging is significant 
to note: the madrasas are owned and supported by local Kurds, unlike the state-sponsored İmam-Hatip schools. Moreover, the official ban of the madrasa education has made these traditional schools more open to ethnonationalist ideas. As renowned Kurdologist Martin Van Bruinessen notes, "The ban in fact may have strengthened the association of the madrasa with Kurdish identity, which was suppressed at the same time. Kurdish mullahs [scholars] were prominent among those who kept an awareness of Kurdish identity alive during the years when the state most forcefully imposed cultural assimilation." ${ }^{37}$

The Association members explained to me how a madrasa graduate acquires in-depth knowledge about Islam compared to official statesponsored İmam-Hatip school graduates. They claim that state-appointed imams lack a true understanding of Islam as being "outsider" to the Kurdish local culture, and therefore, enlightening Kurds should be on the shoulders of the madrasa graduates - the "insider" leaders. In drawing boundaries of moral authority, the ethno-nationalists also utilize differences between Hanafi and Shafite schools of jurisprudence in Sunni Islam by pointing out the fact that Kurds are predominantly Shafiite, while the majority of the state-appointed imams are Turkish and thus follow the Hanafi School..$^{38}$

\section{Public Symbolism}

Civil Friday Prayers are perhaps the best example of the PKK's symbolic localization through collective local rituals, what I call "public symbolism." As the competition escalated between the pro-Islamic activists and the Kurdish ethno-nationalists before the 2011 general election, the PKK started to call on Kurds to refuse to perform the Friday prayers behind the statesponsored imams. Duran Kalkan, a prominent PKK commander, declared, "The [Turkish] state has taken religion from the hands of the people and made it its own religion. Kurds should open their own places of worship. They should find and feed their own men of religion ... I am inviting Kurds to oppose a genocide carried out by the state in the field of religion. ${ }^{{ }^{39}}$

As a part of the PKK's civil disobedience campaign before the general election in June 2011, the DİAYDER imams led the prayers in public squares in many Kurdish-populated cities. In Diyarbakır, the Civil Friday Prayers were performed in the infamous Dağkapı Square where Sheikh Said was hanged in the early years of the Turkish Republic. Inspired by the Arab 
Figure 6.1 A “Civil Friday Prayer" in Dağkapı Square, Diyarbakır

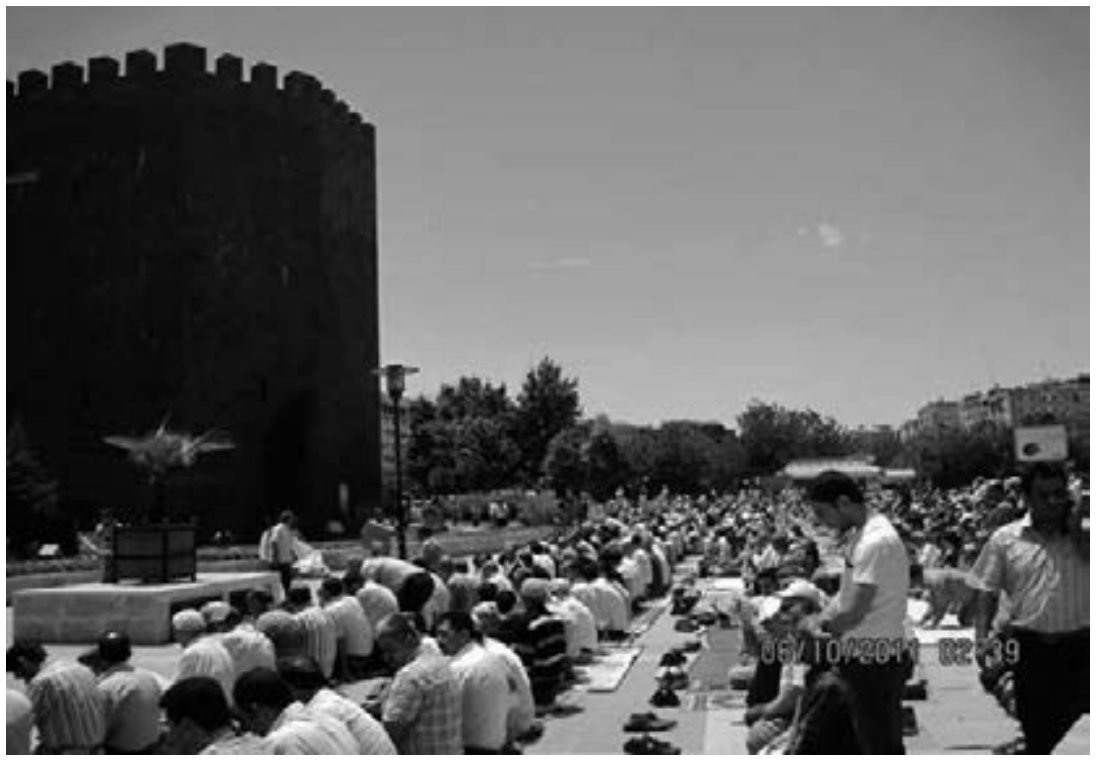

Photo by the author, June 10, 2011

Spring, Kurdish ethno-nationalist activists call the square Kurdish Tahrir, where they organize mass protests and give short briefings to the Turkish press and international journalists after the prayers..$^{40}$

The DIAYDER imams preached sermons in Kurdish and talked about rights of minorities in Islam, the need for mother tongue education in the country, and failures of the AKP government. ${ }^{41}$ In a sermon at Kurdish Tahrir, the DİAYDER president drew a symbolic line through ethnic politics, claiming that they oppose "the system's mosques" as well as those imams who indoctrinate "Turkish-Islamic synthesis" among Kurds. ${ }^{42}$ He added, "Kurds might have some deficiency in terms of their politics; however, they do not need to learn Islam [from those imams]. We have hundreds of scholars who had madrasa education. They can teach religion to everyone. No one should attempt to give us religious lectures. ${ }^{243}$

40 I shadowed one of these press briefings in so-called Kurdish Tahrir on June 10, 2011.

41 Diyarbakur Haber 2011.

42 The expression "Turkish-Islamic synthesis" is a common term that refers to a combination of the Directorate of Religious Affairs (DIYANET), the AKP, and the Gülen activism in the region. 43 Yüksekova Haber 2011. 
After one of the prayers, the BDP deputy Sebahat Tuncel replied to Prime Minister Erdoğan's criticism of the Civil Friday Prayers: "What Erdoğan should know well is the fact that it is not important where and how you offer namaz [prayer]; what matters is to pray with a strong belief. Beliefs are the monopoly of no one." Tuncel's speech was frequently interrupted by slogans "Ya Allah Bismillah Seroke me Öcalan!" (O God, In the Name of God, Our Leader is Öcalan!) ${ }^{44}$

The Civil Friday Prayers attracted great media attention and continued to serve the ethno-nationalist cause after the 2011 general elections. ${ }^{45}$ The DIAYDER imams who led the prayers later appeared on ROJ-TV and other pro-Kurdish channels affiliated with the PKK in order to de-legitimize the AKP and the Gülen movement through an Islamic discourse. For instance, one of the imams condemned Fethullah Gülen's criticisms of the PKK and called him a hypocrite (münafik) on a ROJ-TV news show. ${ }^{46}$

As a response, the AKP government decided to make independent Kurdish imams affiliated with the state. The Directorate of Religious Affairs (DIYANET) announced that it would recruit about 1,00o Kurdish mullahs, i.e., local Kurdish imams who are graduates of the traditional madrasa system that is not officially recognized. It was a conspicuous step to counter the Kurdish ethno-nationalists' increasing engagement with Kurdish local imams. In a press conference, then-Deputy Prime Minister Bekir Bozdağ openly stated, "These imams are vocal and well-respected in their communities, and their words stop or mobilize people. Control of these imams by other forces will be prevented thanks to this (new official recruitment). ${ }^{247}$

\section{Memory Work}

Pro-Kurdish activists' frequent utilization of local Islamic repertoires in constructing Kurdish collective memory is a significant contributor to the PKK's symbolic localization process. Perhaps the most striking example of the PKK's memory work is in the reconstruction of Said Nursi's identity as a Kurdish freedom fighter. What makes Nursi's persona an arena of competition is his equally great prestige among conservative/religious Turks

\footnotetext{
44 Bianet 2011.

45 The Civil Friday Prayers continued until summer 2013, lasting thirty months.

46 The ROJ-TV preferred to use a religious language in presenting the news: "Fethullah Gülen is an infidel!" See, HaberYek 2011.

47 Radikal 2011. Similar dynamics of contention occurred in Nicaragua when the state apparatus and the affiliated Catholic church were challenged by the liberation theologians like Ernesto Cardinale. See, Lewellen 1989.
} 
because he is seen as the father of the Nur movement, which later generated the Hizmet movement of Fethullah Gülen. Thus, it is not coincidental that contests over Said Nursi's persona started at precisely the time when Hizmet emerged as a significant actor in the Southeast.

Nursi was a significant Kurdish scholar during the late Ottoman Empire, and later, an outspoken critic during the early years of the Turkish Republic. Nursi defended the implementation of constitutional rights for Ottoman citizens based on an Islamic democracy. He was able to convince Sultan Reşad to establish a major university for Kurdish youth on the shores of Lake Van. Nursi also played a significant role in the foundation of modern Turkey by supporting the national independence war led by Mustafa Kemal Atatürk, and as a result, he was repeatedly invited to Ankara, the seat of the national government. ${ }^{48}$

The secularist policies of the new Turkish Republic, however, not only alienated Nursi but also criminalized him. Nursi's magnum opus, Risale- $i$ Nur - a 6,00o-page-long exegesis of the Quran - was outlawed and his students faced harsh sentences. Spending twenty-five years being exiled, detained, or jailed, Nursi was under great pressure for being allegedly an enemy of the state. Nursi's commitment to non-violent resistance as well as his philosophy that combines modern sciences and traditional Islamic sources received much attention from diverse segments of Turkish society. ${ }^{49}$ Since Nursi's death, his text-based activism has been fragmented into eight groups, including a community centered around the preacher Fethullah Gülen, popularly known as the Gülen movement..$^{50}$

The Kurdish ethno-nationalists have long interpreted Said Nursi as "dangerous" to their cause because of his strong condemnation of the Marxist left. ${ }^{51}$ In recent years, however, Said Nursi's legacy is being reinterpreted. The ethno-nationalists often emphasize the scholar's ethnic origin by calling him Said-i Kürdi (Kurdish Said) instead of Said Nursi (Said from the Nurs village). Surprising many, the pro-Kurdish party called for an investigation into Said Nursi's lost grave by proposing a bid for the reinstatement of Nursi's

48 Vahide 2003: 12. For Nursi's comprehensive biographies in Turkish, see Badıllı 1998 and Şahiner 1998.

49 Nursi's text-based Islamic movement, called the Nur movement, has grown rapidly in post-1950 Turkey, especially among Turkish youth. According to prominent Turkish sociologist Şerif Mardin (1989), one cannot understand Islamic activism in Turkey without grasping the influence of Said Nursi.

50 Yavuz 2003: 312 .

51 White 2000: 36 . 
Figure 6.2 News story narrating how Said Nursi's persona was used by pro-

Kurdish party (DTP) electoral campaign offices, published in

Hizbullah's weekly, Doğru Haber. The headline reads, “It's Now DTP's

Turn to Exploit Religion." Issue no: 49, March 6-12, 2009

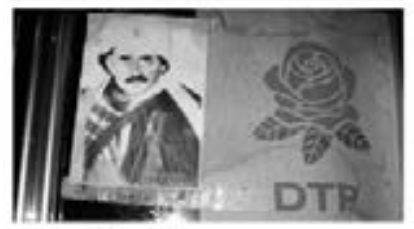

Dini kullanma

sırası DTP'de

Hakn doberkerinden kopuk ahniycteriyle günden gine erinen ve careyi dini dejerteri kstismar et. meke arayan CrP' den sonra Ramazan aynda hal. kn obuinûn kine baka baka su içenleri barndiran

bir zhniytle sahip DTP de ayn youteme basuros

rights in the Turkish Parliament. Some PKK activists even zealously carry Nursi posters in Newroz (i.e. Kurdish New Year) celebrations. ${ }^{5^{2}}$

Although some prominent Kurdish Islamic groups such as Med-Zehra have long claimed that Said Nursi was misinterpreted by the Turkish Islamic Nur community, the PKK's involvement in the debate over Said Nursi's persona is quite recent. For the Med-Zehra group, Turkish followers of the Nur movement have developed "racist" misinterpretations of Risale-i Nur, i.e. Said Nursi's magnum opus, and deliberately removed the words "Kurds" and "Kurdistan" from his writings. Med-Zehra activists believe that Nursi's Kurdish identity was suppressed and certain of his works were overstressed at the expense of some of his earlier works. Siddık Şeyhanzade, the leader of Med-Zehra, claims that there are about 500 words that have been deliberately altered or removed in the Risale-i Nur. In our conversation, he claimed that these actions were undertaken by prominent Nur movement leaders because they found some words to be "politically incorrect" or "too critical" of the Turkish state regime at the time..$^{53}$

52 Vatan 2008; Hürriyet 2008.

53 The author's interview with Sıddık Dursun Şeyhanzade. Istanbul, June 8, 2009. Şeyhanzade makes similar claims in his books. See, for example, Şeyhanzade 2007: 10-13. 
Although the Med-Zehra group's accusations target the traditional Nur movements ${ }^{54}$ these allegations are now echoed by the Kurdish ethno-nationalists, but with an altered target: Fethullah Gülen and his followers. Hizmet activists' call for Islam is denounced as Turkified, so "hypocritical" in many ways that it even distorts its intellectual source, i.e. Said Nursi, because of his Kurdish roots. Framing the issue as such, the ethno-nationalists engage in strategic subversion, defining Nursi's "real" identity through condemning competitor activism, Hizmet. ${ }^{55}$

The ethno-nationalists especially criticize Kurdish Hizmet activists for their portrayal of a conformist Said Nursi. Instead, they commemorate Nursi as a freedom fighter and as a staunch critic of the state. "We want both realities open to the public: the truths about Said-i Kürdi and his graveyard's location," said Mehmet Karabaş, a pro-Kurdish party deputy, during our interview in the Turkish Parliament. "Said-i Kürdi was an opponent. In his time, he was an opponent of the Republic, the Kemalism, and the regime. ${ }^{56}$ In the same vein, an ethno-nationalist commentator stated:

Said Kürdi was never afraid, nor did he hesitate to defend his beliefs. He always believed God would defend the Quran and that the truth of Islam would prevail ... [However] Gülen for a long time praised the military, and until recently he did not dare criticize the generals. Didn't Gülen know the military's policy of wrongdoing toward the Kurdish population in eastern Turkey? If he knew, why did he keep silent? ... When Atatürk invited Said Kürdi to Ankara, the Great Assembly welcomed him with enthusiasm and an official ceremony. Ankara offered him a position as minister of religion, but Said Kürdi was displeased at what he saw in Ankara and told Atatürk without hesitation that most of the Assembly members were ignorant of Islam and do not read the prayers five times a day. He refused to work with the secularist system. ${ }^{57}$

In criticizing the Gülen, therefore, ethno-nationalists can construct an authentic Kurdish Muslim identity in a new fashion.

Moreover, PKK activists re-constructed Nursi as a voice of the oppressed within Islamic discourse. For instance, a biographical novel, Son Derviş

54 In my interview, Şeyhanzade mentioned a few names of Nur movement leaders without any reference to Fethullah Gülen.

55 See, for example, $A N F$ 2007; Mizell 2009; Özgür Gündem 2009.

56 The author's interview with Mehmet Nezir Karabaş, Turkish Grand National Assembly, Ankara, June 24, 2009.

57 See, Mizell 2009. 
(The Last Dervish), describes Nursi as a Batiniyy $a^{58}$ scholar who challenges mainstream Islam. "I believe Said-i Kürdi was a major scholar from the Batiniyya tradition of Islam," says Metin Aktaş, the author. "Said-i Kürdi's rebellion against the oppression of Mustafa Pasha, the commander of Hamidiye troops and the leader of Miran tribe as a chief landlord, in his youth shows his connection with the Batiniyya School. He never accepted social injustices, exploitation, or oppression.".59

Aktaş specifically targets Gülen and some Kurdish Islamic groups when he explains how Nursi's real identity as a Batiniyya scholar signifies a total break from political Islam:

The Batiniyya School of Islam does not give importance to rituals too much; it does not reify them. According to Batinis, all rules and rituals are subject to change and renewal with only one exception: one's love for the Creator. Today, some followers of Said-i Kürdi say that he believed in the unchangeable and non-renewable character of rules ... [Instead] Said-i Kürdi was a scholar who devoted his life to social change, reform, and justice... Said-i Kürdi was not a person as we are told, that is, one who obeys the rules in rigid ways; rather, he worked for changing lifestyles and rules that make our people's life hard.

Thus, the re-definition of Nursi as a freedom fighter is aimed to contest the legitimacy of rival Islamic activists. The Gülen movement is accused of constructing a "pro-Turkish" Nursi as "market merchandise." ${ }^{60}$ In the words of the PKK leader, Abdullah Öcalan,

As known, Said Nursi did not rebel against the Republic like Shaikh Said did; however, he did not embrace the Republic either. Interestingly though, Said Nursi's Gülenist cadres now are an important power bloc within the state ... They do not have anything to do with the real Islam. Genuine Islam ended when the children of $\mathrm{Hz}$. Ali, the grandsons of Hz. Muhammad, were killed during the Muawiya reign. Since that period, anti-Islam has dominated rather than Islam. Anti-Islam equals fake Islam. ${ }^{61}$

$5^{8}$ Batiniyya refers to smaller and marginal groups in the Islamic community, such as Alevism, Ismailism, and some branches of Sufism, which prefer private esoteric (Batini) interpretations of the Qur'an to more public, exoteric level of meanings (Zahiri).

59 Newroz 2009.

60 Kurdistan Post 2010.

61 Öcalan 2009c. 
Figure 6.3 A store's façade where an embroidery image of Said Nursi stands among those of domestic and global revolutionary figures

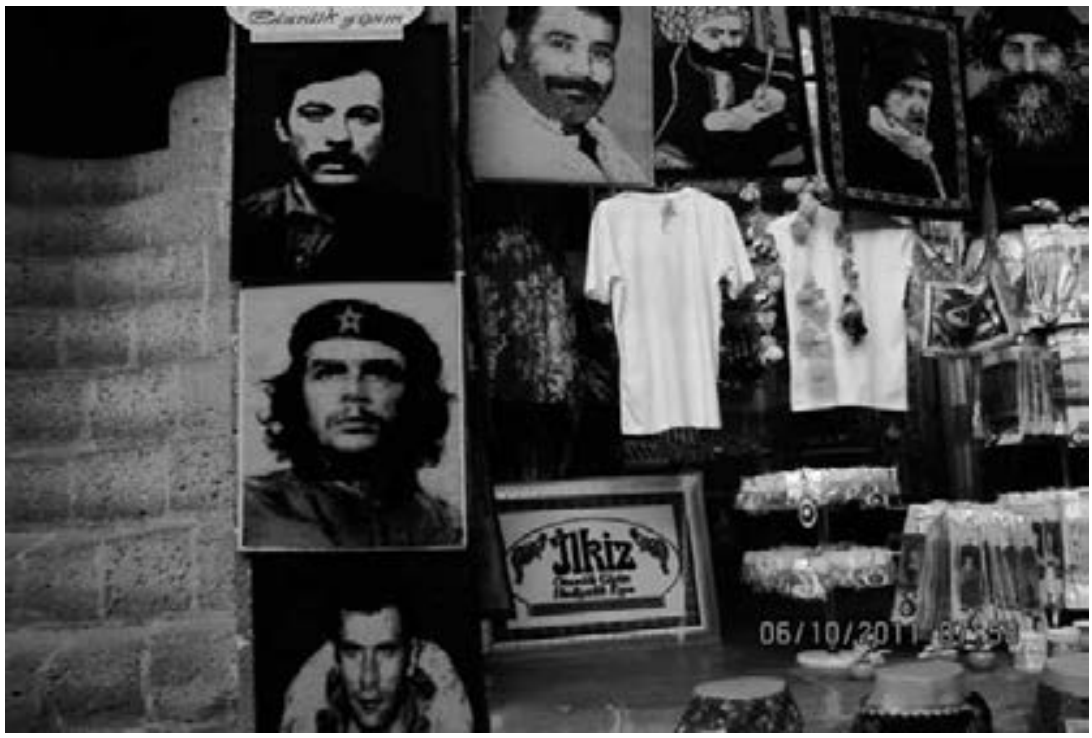

Photo by the author, Diyarbakır, June 10, 2011

\section{Symbolic Localization and Conflict Transformation}

The PKK's strategic discursive engagement with local Islamic repertories is not a temporary political agenda; rather, it has shaped the ground for a gradual ideological transformation among ethno-nationalists. The PKK's ideological transformation is clearly visible in recent writings of the movement's prominent ideologue, Abdullah Öcalan. Öcalan's late prison writings have long discussions on Islamic history and ethics that show the unprecedented ideological change in his style. Öcalan thoroughly depicts Islam as a revolutionizing force.$^{62}$ In 2013 , the PKK's public rally for the peace negotiations with Turkish state was heavily Islamic in tone. ${ }^{63}$

Lately, Öcalan called PKK activists to organize major conference series on Islam. "Against those who betray Islam," he said, Kurdish activists should have in-depth discussions "similar to the Prophet Muhammad's consultation meetings (Şûra) in his city Medina." Öcalan added that these gatherings should be "in accordance with the spirit of the historical figures such as

62 Öcalan 2007: 122-47.

63 For the Newroz declaration, see Milat 2013. 
Sheikh Said." ${ }^{64}$ Despite welcoming this message, a pro-Kurdish party deputy, Altan Tan, criticized the PKK's earlier attempts for being intellectually too superficial, calling for serious scholarly engagement with Islam. Altan said that Öcalan's message should spark such further Islamic activism in the PKK movement. ${ }^{65}$ Having Alevi background, another deputy commented that their movement has been at peace with Islam for a long time, as long as it's not a tool of oppression in the hands of political elite. Their understanding of Islam, she said, is a "democratic" and "cultural" one. ${ }^{66}$

As a result of in-group discussions, a major conference, Democratic Islamic Congress of Kurdistan, was held in Diyarbakır in May 2014. Öcalan's message to the conference highlighted the PKK's ideological embrace of Islam. "My brothers in Islamic faith," greeted Öcalan, "It is essential not to suffocate our movement through a false dichotomy between religious and secular. This dichotomy is a product of Western ideological hegemony. It is also wrong to squeeze Islam into these categorizations (religious versus secular)." In his long letter, the PKK leader stressed how both major Sunni and Shiite movements "betray" true Islam, mentioning the need "for a new institutionalization of Islam in Kurdistan.” Öcalan argued that the British Empire imposed nationalist ideologies to divide the Muslim world, and later, nation states such as Saudi Arabia and Iran excessively utilized "the virus of nationalism." Öcalan further stated that Hizbullah and Al-Qaeda represent "contemporary fascism that was imposed on Islamic 'ummah' by capitalist nihilism." ${ }^{67}$

Considering ideology as a relational discursive process through the notion of symbolic localization would shed light on the gradual changes in revolutionary ideologies. As defined earlier, symbolic localization refers to a discursive process of collective reputation work. In this process, revolutionaries blend local cultural repertoires and their "we" identity in order to build recognition, legitimacy, and prestige in the eyes of local populations. How do revolutionaries attempt to localize through discursive politics? What are the mechanisms of symbolic localization? I suggest three cultural instruments most frequently employed: moral authority building, public symbolism, and memory work.

Moral Authority Building: Religious authority figures may play a role as moral entrepreneurs who re-articulate revolutionary culture within the mainstream discourse. Once institutionalized, these discursive practices 
Figure 6.4 An electronic billboard advertising Altan Tan, a renowned pro-Islamic politician, as a pro-Kurdish party nominee

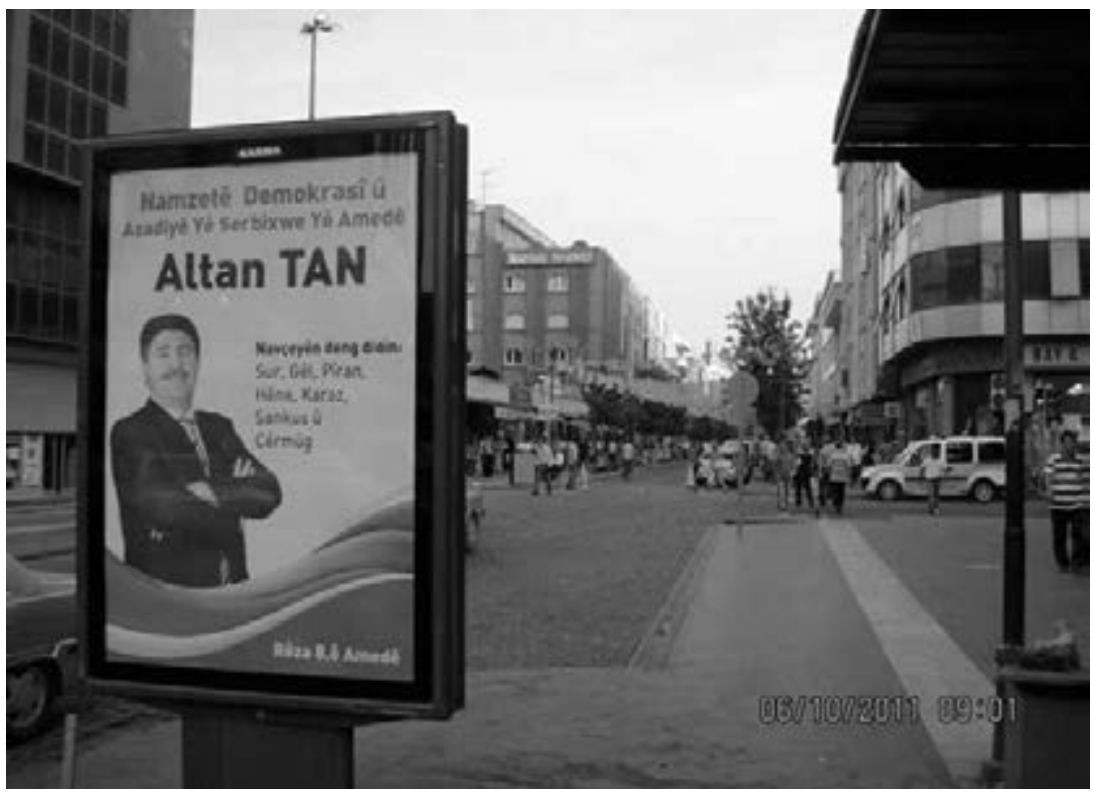

Photo by the author, Diyarbakır, June 10, 2011

might form a new source of legitimacy. I call this process "moral authority building." Moral authority building provides strong emotional power for revolutionaries in the larger society. Nonetheless, the group's ideology is in gradual transformation in this discursive process. Revolutionaries become entrenched in their moral discourse in a relational manner: the Kurdish ethno-nationalist imams targeted the rival Islamic groups, questioning their authenticity.

These imams introduced ideological diversity within the movement and thus contributed to the PKK's ideological transformation. Hank Johnston's research on Spain highlights the importance of ideological diversity within a social movement. Studying the Catalonian anti-Franco movement, Johnston points out that the Christian, Marxist, and conservative ideological elements expanded the movement's "ability to encompass a variety of different interpretations and to incorporate new and unfamiliar events. ${ }^{\prime \prime 8}$ The PKK movement has further gained ideological diversity by supporting popular 
(and subsequently elected) candidates having Islamic worldviews such as Altan Tan, Serafettin Elci, and Hüda Kaya. ${ }^{69}$

Public Symbolism: Another discursive mechanism of symbolic localization is "public symbolism." As discussed above, revolutionaries' public image is often tarnished as they are labeled as terrorists. In dealing with this stigma, revolutionaries construct innovative discursive rituals in which they could engage with the public at large. These rituals are collective and often performed by moral authority figures whose words can attract public attention. Appealing to moral authority on their behalf, revolutionaries utilize vernacular religious repertoires to resonate with local residents. Through these moral performances, radical activists seek to change public perception and thus to be accepted as a part of the moral domain. "If the first step in dehumanization is to reduce an other to a simple phrase, an enemy, a parasite, or a terrorist," writes Ron Eyerman, "the first step in moral performance or empathy is attentiveness to the complexity of another's status and situation, something which can be viewed as an attribution of subjectivity."70

Revolutionary appeals to moral authority in order to win public sympathy were evident in the Nicaraguan and Iranian revolutions in 1979. Sandinistas gained remarkable attention as they employed liberation theology discourse through collective rituals in churches. Similar to the Kurdish imams examined here, public events led by Catholic priests provided a broader base of legitimacy for the Sandinistas' armed group, FSLN. Although these priests were not among the guerilla fighters, they acted as organic intellectuals for the poor masses. ${ }^{71}$ Public symbolism enabled the Sandinistas to localize due to the pervasiveness of Christian values in Nicaraguan culture. In this process of symbolic localization, Sandinista ideology was mobilized as well. Giulio Girardi documents how these Catholic activists broadened Sandinista discourse toward a more inclusive orientation..$^{2}$

Memory Work: Memory work refers to a discursive process of revisiting the past through new lenses in order to shape the present. Agents of memory

69 Ideological diversity, however, may lead to in-group disputes and clashes. See, Benford 1993. In this sense, the relational quality of symbolic localization is an important dynamic to understand: the competition drive has impeded in-group strife. The Kurdish imams are embraced by the PKK movement, including its most secular elements, because of the fact that the local Islamic representation boosted the PKK's status over its rivals (the AKP and the Gülen movement).

70 Eyerman 2006: 201.

71 Sawchuk 1997: 46.

72 Girardi 1989: 36-38. 
often fight over who should be remembered and how to interpret the past. ${ }^{73}$ As Eric Hobsbawm points out, nationalist activists often supported their cause by reference to a "people's past," to "traditions of revolution," and to the activists' "heroes and martyrs." ${ }^{74}$ Such re-construction of local historical figures provides revolutionaries legitimacy, recognition, and moral power among indigenous populations.

Memory work, however, is bounded by the local competition structures. "People's ability to reconstruct the past," claims Michael Schudson, "is limited by the crucial social fact that other people within their awareness are trying to do the same thing." 75 Through Said Nursi and Sheik Said, Kurdish ethno-nationalists are involved in "mnemonic battles" with their pro-Islamic rivals, and thus, shaping their narratives in a relational manner. ${ }^{76}$ These interactive and dynamic semiotic practices of revolutionaries influence the movement ideology in the long term.

I now turn to a most intriguing contemporaneous process: Hizbullah's symbolic localization. Pro-Islamic activists have increasingly become ethnonationalist under the forces of civil society competition. Conflict transformation has been underway as Kurdish, Islamic, and ethnic identities blur. 



\title{
$7 \quad$ Îslam Çareser e
}

\author{
Islamic Activists Discover Kurdish
}

In 2009, the AKP government launched an official Kurdish TV channel, TRT Şeş, when the Constitutional Court was preparing for the closure of yet another pro-Kurdish party, the DTP, due to its links to the PKK. Prime Minister Erdoğan inaugurated the channel by uttering the Kurdish words “TRT Şeş bi xêr be!" (May TRT 6 be beneficial!). The pro-Islamic party's move was a surprising step to many Kurds and was called "a great revolution.". Turkey's weakening secularist elite seemed not happy about these reforms; only two years before the launch of TRT Şeş, the highest administrative court ruled to dismiss Abdullah Demirbaş, the mayor of Diyarbakır's Sur Municipality, on the grounds that the municipality had published some brochures "in languages other than Turkish" (read:Kurdish). ${ }^{2}$ Soon after the pro-Islamic AKP's introduction of TRT Şeş, private enterprises were allowed to open channels in Kurdish. Two brands were quick to step onto the stage; Dünya-TV and Çağrı TV, owned by the Gülen movement and Hizbullah.

The PKK had long enjoyed a monopoly over Kurdish channels since the establishment of MED-TV, later named ROJ-TV, in 1995, as a satellite TV channel that operates in various European countries. ${ }^{3}$ As the PKK's monopoly was now challenged by pro-Islamic actors, the Kurdish language has become an arena of fierce contestation. Through competition, pro-Islamic activists have gradually become pro-Kurdish in their discourse. I argue that this discursive shift paves the way for an ideological transformation and the symbolic localization of pro-Islamic actors despite the presence of

1 Author's interview with Abdurrahman Kurt, a Kurdish deputy from the AKP at the time, in the Turkish Grand National Assembly, Ankara. June 26, 2009. The prime minister's speech reminded the Turkish public of the Leyla Zana crisis in the parliament. In 1991, pro-Kurdish party deputy Leyla Zana was banned from politics and imprisoned because she had spoken Kurdish during the oath ceremony at the Turkish Grand National Assembly.

2 The multilingual municipality services also included Syriac and English. For the details of the case, see Olson 2009: 41-42.

3 The Turkish State's ban on using Kurdish in mass communication was the primary reason for this monopoly. See, Hassanpour 1998; Romano 2002. Due to pressure from Turkey, MED-TV's license was revoked by the UK in 1999. PKK activists established a new channel, MEDYA-TV, in France. Again, upon Turkey's pressure on France, the French authorities shut down MEDYA-TV in 2004. Within a few months, Kurdish ethno-nationalists successfully established ROJ-TV, this time in Denmark. Since 2004, the Turkish authorities demand ROJ-TV's closure, preparing more than twenty files that indicate the link between the channel and the PKK. See, Ayata 2011: 528. 
nascent ethno-nationalist feelings, especially observed through their keen interest in the Kurdish language. Thus, rival Kurds' civic competition does not only lead to the PKK's ideological embracement of Islam but also to a transformation in the Gülen and Hizbullah movements.

\section{Increasing Competition over Kurdish Language}

The "war of words" between TRT Şeş and ROJ-TV began very early on:

On 19 September (2008), Ibrahim Şahin, director of TRT, announced to reporters that the TRT Kurdish channel would begin in March 2009 and would be broadcast on, interestingly enough, ROJ-TV, and it would be available anywhere that ROJ-TV was broadcast. This announcement certainly must have been met with surprise by the 56 Kurdish mayors who had been indicted for requesting Denmark's Prime Minister Fogger Rasmussen not to shut down ROJ-TV, which broadcasts from his country. ${ }^{4}$

TRT Şeş noticeably challenged ROJ-TV in its programming and outreach, and the competition was clear to the naked eye. As I entered the room of Sinan İlhan, the founding director of TRT Şeş, he had two large TV screens, airing TRT Şeş and ROJ-TV. İlhan claimed that TRT Şeş truly respects the Islamic identity of Kurds and that ROJ-TV just started recently to air Islamic cultural programs in order to compete with TRT Şeş. ${ }^{5}$ My conversations with Remzi Ketenci, the director of the Dünya-TV based in Antep, left a similar impression on me: pro-Islamic activists aim to block the PKK's propaganda by reaching out to the Kurds in their native language. ${ }^{6}$

As a response, the PKK especially targets those Kurds who make shows for TRT Şeş. Appearing on ROJ-TV, Bahoz Erdal, a chief PKK commander, stated that "anyone who participates in the TRT Şeş is a jash, traitor."7 Pro-PKK media often call TRT Şeş “TRT Jash” pejoratively. These threats discouraged Kurdish musicians and local male singers (dengbêj), and therefore, TRT Şeş experienced difficulties in recruiting celebrities. ${ }^{8}$

4 Quoted in Olson 2009: 45. ROJ-TV now broadcasts in seventy countries around the world via satellite, reaching even Kurdish refugees in Japan and Australia (Ayata 2011: 526 ).

5 Author's interview with Sinan İlhan at TRT headquarters office. Ankara, June 28, 2009. See, also, Ayata 2011: 530 .

6 Author's interview with Remzi Ketenci, Gaziantep, May 30, 2011.

$7 \quad$ KM 2009.

8 Ayata 2011: 531. 
Figure 7.1 A TZP Kurdî protest banner in Kurdish national colors red, yellow, and green. It reads "As my tongue slays, my sword would never be in its sheath."

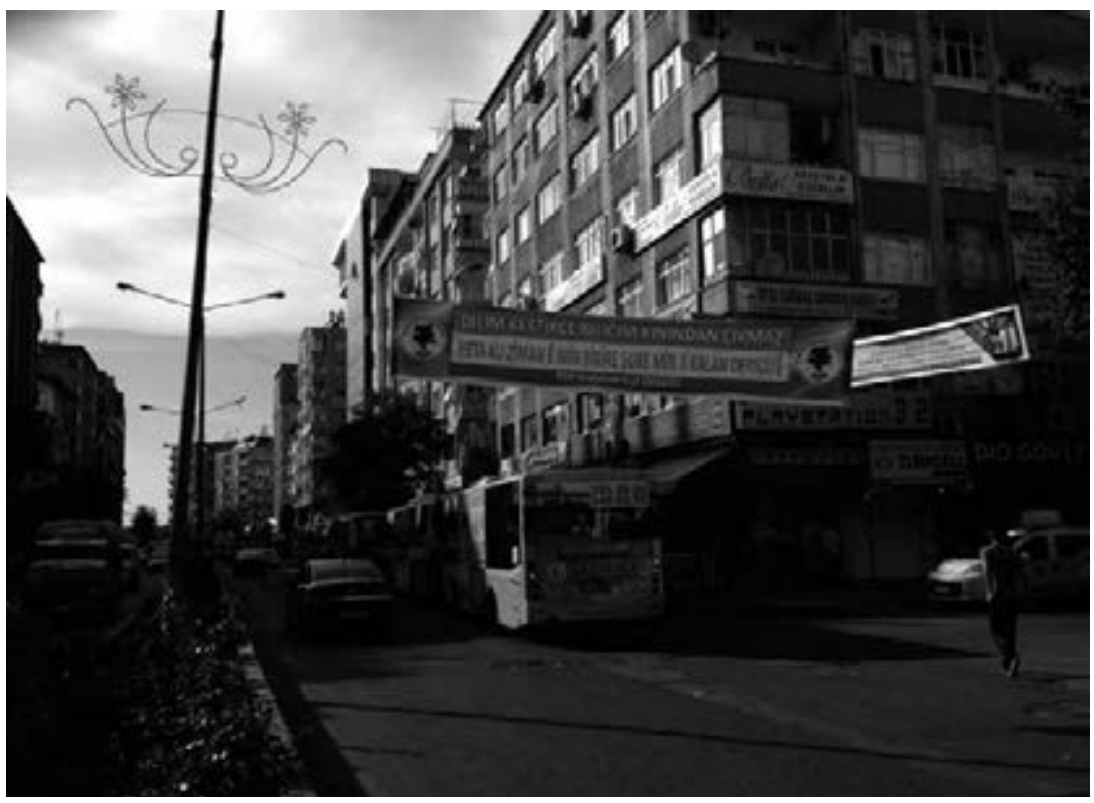

Photo by the author, Diyarbakır, May 28, 2013

Kurdish ethno-nationalists primarily frame TRT Şeş as a Turkish state project instead of a pro-Islamic project. As my informants often repeated, "The state has long cursed Kurds in Turkish. Now it curses in Kurdish." The foreign news editor of Azadiya Welat, the PKK's flagship daily in Kurdish, put it in plain terms: "These reforms are part of the war against Kurds. So TRT Şeş should not even be called a reform. And yet Kurds will surely benefit from this de facto condition." 9

The long-term ethno-nationalist strategy, however, was not simple criticism: the pro-Kurdish party launched the "Education in the Mother Tongue Initiative” just a few days after the government's announcement of the TRT Şeş initiative. "There will be demonstrations for the right of education in the mother language," said pro-Kurdish party group leader Selahattin Demirtaş. "We will support this campaign within the framework of a democratic plan." 
The PKK decided to strengthen its civic platform, TZP Kurdî (Tevgera Ziman û Perverdehiya Kurdî), Movement for Kurdish Language and Education. Although TZP Kurdî was formed in 2006, it was not strongly supported within the Kurdish ethno-nationalist movement until the "Education in the Mother Tongue Initiative" began in late 2008. ${ }^{11}$ Kurdish language institutes such as Institute Kurdî, opened following the EU-led reforms in 2004, were brought under the umbrella of TZP Kurdî. ${ }^{12}$ TZP Kurdî organized mass protests in various Kurdish cities and called for a boycott of the public educational system. ${ }^{13}$ TZP Kurdîalso celebrates International Mother Language Day, February 21, with various activities. ${ }^{14}$ In a major conference on education in the mother tongue in August 2013, TZP Kurdî declared the path for pushing the agenda systematically: - TZP-Kurdî sees education in the mother tongue as an indispensable right and doesn't make it a matter of debate. In this respect, it condemns Turkish Prime Minister Recep Tayyip Erdoğan's statements (in which he had said that the recognition of Kurdish as a language of education would lead to a separation in the country).

- All Kurdish institutions and establishments, as well as their executives and politicians, should perform their work in the Kurdish language. Delegates of the Conference will be responsible for the supervision of these works.

- Students and teachers at all schools should communicate with each other in their mother tongue.

- Simultaneous demonstrations should take place in all provinces and districts every week to voice the demands for mother tongue education.

- Mass demonstrations should take place everywhere on 16 September (the beginning of the school year).

- All Kurdish establishments should reject the institutions that perform their language work in line with the mindset and interests of the state.

- All Kurdish municipalities should open kindergartens providing education in the mother language.

- All executives and deputies nominated as candidates for local and general elections should certainly know their mother language very well.

11 Qahir Bateyî, then spokesperson of TZP Kurdî, complained that initially they were not taken seriously within the PKK movement. See, his interview with Mehmet Ali Küçük (2008). 12 Author's interview with an activist at Institute Kurdî, Diyarbakır Kürt Enstitüsü. Diyarbakır, July 12,2009 .

13 Kaya 2013: 116.

14 ANF 2014a. 
- All executives and workers of Kurdish municipalities should use their mother tongue in daily life and develop projects on the mother tongue issue. ${ }^{15}$

Within a few weeks, the AKP government declared new constitutional amendments that targeted some barriers to the use of Kurdish language. Accordingly, the establishment of private schools that give education in the mother tongue is endorsed. Moreover, political parties are allowed to make propaganda in "other" languages (that is, Kurdish). Many pro-Kurdish party members had been criminalized due to their public speeches in Kurdish during their electoral campaigns. ${ }^{16}$

The government's "democratization package" also included the recognition of the right to claim local (original) village names. Since thousands of Kurdish villages were systematically renamed by the Turkish state, the pro-Kurdish party had earlier proposed re-naming of settlements, thus, naming in Kurdish. ${ }^{17}$

Unlike in the PKK's early years, Kurdish ethno-nationalists are now careful to express local city names in Kurdish in their publications as well as in daily routines. A few examples include Amed instead of Diyarbakır, Riha instead of Urfa, Dilok instead of Antep, and Hewler instead of Erbil. In some cities, the verbal expression would not make much of a difference, such as Van (in Turkish) and Wan (in Kurdish). However, if written as Wan, the city is symbolically claimed against the "oppressive" Turkish regime. Until September 30, 2013, the Turkish Constitution rejected employment of letters such as " $w$ " that are not included in the law with respect to the Latin alphabet revolution in 1928. Although the law was meant to abolish

15 For the full final declaration of the conference, see $A N F$ 2013.

16 Nicole Watts (2010:116) narrates how pro-Kurdish party activists' increasing usage of Kurdish language was legally punished:

"In 2006 and 2007 at least twenty investigations of the Diyarbakır metropolitan municipality and the Diyarbakır municipalities of Sur and Kayapınar were opened for activities that included the following: billboards advertising a human rights week in Turkish, Kurmanji, and Zazaki; the Sur municipality's release of a Kurdish translation of the free Linux software release 'Ubuntu'; municipal use of Kurdish to officiate during wedding ceremonies; publication of children's books in Kurdish and Turkish; publication of public brochures on health and cleanliness in Kurdish and Turkish; and the publication by the greater Diyarbakır metropolitan municipality of a book of Kurdish baby names. As of mid-2008 about twenty-five of the legal prosecutions against Baydemir [then Mayor of the Diyarbakır metropolitan municipality] directly concerned use of the Kurdish language."

17 For the democratization package in details, see Radikal 2013a. The pro-Kurdish DTP's proposal, an amendment to Law 5442, dated back to April 20, 2008. Thus, the AKP's response in September 2013 was an outcome of long contentious politics. For details, see Jongerden 2009. 
the Arabic alphabet in modern Turkey, it was frequently utilized against the Kurdish language that employs the non-Turkish (unlisted) letters 'w,' 'x,' and 'q.'

The Gülen movement strongly supported the AKP's new language reforms. Earlier, in the summer of 2013, Fethullah Gülen gave an interview to Rudaw, a Kurdish newspaper in Iraqi Kurdistan, expressing his support for education in the mother tongue. Recognizing the AKP's bargaining plans by utilizing such reforms, Gülen emphasized that such issues should not be objects of any political bargaining:

Human rights and freedoms are natural rights and no one has the authority to grant those rights to others as if they were favors ... It is bizarre to discriminate based on ethnic differences since being Turkish or Kurdish was not our choice. All human beings, including prophets, are equal since they were created by God as humans.

In the same interview, Gülen also challenged the official Turkish discourse by stating that Turkey should not only grant Kurdish rights but also take a leading role in defending and supporting all Kurds around the globe. ${ }^{18}$

Fethullah Gülen's statements were influential in shaping Hizmet's discourse. When asked about Hizmet's proposal for education in Kurdish, the chairman of the Journalists and Writers Foundation, a prominent Hizmet organization, pointed out the fact that the movement Gülen schools abroad offer four languages, namely the local language, regional language, English, and Turkish. He suggested a similar policy in Turkey:

When we earlier proposed a constitutional model too, we had put forward the proposal that no constitutional restriction should exist for the Kurdish language to be taught as a local language. In this regard, it is essential that the curriculum at such schools is redesigned in line with the local people's demands in the Southeast. ${ }^{19}$

Following the AKP's declaration of democratization packet, a private Hizmet school in Şırnak announced that it was institutionally ready for 
Figure 7.2 A flyer in Kurdish for International Language and Culture Fest, organized by Gülen/Hizmet activists

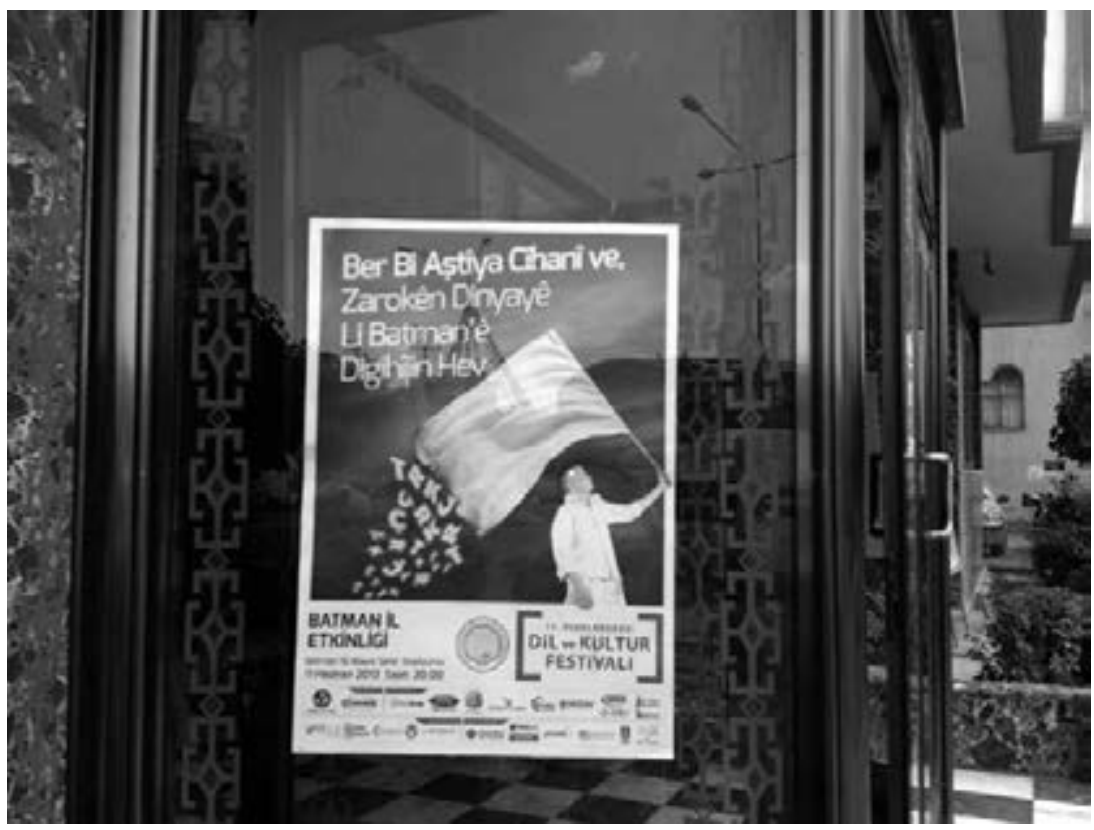

Photo by the author, Batman, June 1, 2013

full education in Kurdish. Fethullah Gülen called on the state officials to take serious and swift steps to train Kurdish language teachers in order to back reforms institutionally. He added, "these steps should not be taken in an offensive manner as if it is a gift granted upon them.. ${ }^{20}$

Well known for organizing the annual Turkish Language Olympiads, Hizmet activists now set up International Language and Culture Fests instead, putting Kurdish and Arabic on equal footing with Turkish. Hizmet school teachers in Iraqi Kurdistan share their experiences with the activists in Diyarbakır and Batman: education in Kurdish, Arabic, Turkish, and English has been a signature feature of Hizmet schools in Kurdistan, serving students from Kurdish, Turkmen, and Arab backgrounds. Gülen activists also relate their embrace of the Kurdish language to the ideas of Said Nursi, who is accepted as the ideological founder of Hizmet schools. ${ }^{21}$ 
The opening of TRT Şeş not only triggered "a war of words," but also influenced the growing ethnic pride of Islamic activists. Such official recognition of the Kurdish language has encouraged the public use of Kurdish at local events in the civic sphere including mosques, coffee houses, funeral homes, and wedding ceremonies. In mosques, people began to hear recitations of mevlid, i.e. commemoration poems for the Prophet Muhammad, in Kurdish instead of Turkish. ${ }^{22}$ Nur brotherhood groups such as Nûbihar have become more active in publications in Kurdish, even engaging linguistic debates unprecedentedly. ${ }^{23}$ A representative of Nûbihar, for example, told me that they avoid the secularist fallacy of Kurdish ethno-nationalists in the usage of Kurdish. Similar to the Turkish state's early Republican period, PKK-linked media discards Arabic-rooted words in Kurdish; instead, they systematically choose Persian-rooted words.

More visibly, Hizbullah has also started to become active in Kurdish Islamic music. The groups' musicians take center stage in wedding celebrations and commemorational gatherings of their potential constituency. The movement now has its own production company, Özlem Ajans, which releases new albums each year. Mihemed, one of the prominent singers of Hizbullah, perceives their effort as a contribution to the Kurdish culture: "Regardless of sales, we try to make an album in every two-three months as a cultural work. We've been making albums in both Kurdish and Turkish for a long time; yet lately we have focused our concentration on albums in Kurdish." In our conversation, Mihemed also explained how they emulate Kurdish ethno-nationalists in making Kurdish protest music:

It began with a question like why don't we have our own Ahmet Kaya. ${ }^{24}$ Defending your own rights and raising your voice cannot be possible through songs for love of God. In fact, those who love God are the ones being oppressed and we would like to give them voice through our music. ${ }^{25}$

Pro-Islamic activists, thus, have started to localize symbolically.

24 Ahmet Kaya (1957-2000) was a famous Kurdish poet and singer. His protest music against oppression and state violence has been influential among both Kurdish and Turkish leftists. He left Turkey in 1999 because of charges against him because his political views are sympathetic to the PKK.

25 Author's interview. Istanbul, June 7, 2009. 


\section{Hizbullah: From Ayatollah Khomeini to Said Nursi}

Although active as an underground organization since the 1980s, Hizbullah published its first document in 2004, Hizbullah In Its Own Words: Selections from the History of Struggle written by the movement's new leader Isa Altsoy under the pseudonym I. Bagasi. In this short book, Altsoy emphasized the movement's embedded nature of Kurdish-ness:

Hizbullah is an Islamic movement, centered in Kurdistan, dedicated to defending the Muslim Kurds' Islamic and human rights and to finding solutions to historical, social, political, economic, and cultural problems through an Islamic approach. Hizbullah's duty is to struggle against oppression, tyranny, and injustice to make Kurds free. ${ }^{26}$

The document was revolutionary. It was not only the first publication in the name of Hizbullah but was also a declaration that it was to be a "Kurdish" movement. The book signaled the path for Hizbullah in the next decade. In the same year, Hizbullah activists opened Mustazaf-Der, the first civil society organization of the movement. Since then, they have narrated their movement's history to emphasize its Kurdish Islamic identity. During the 1990s, however, when Hizbullah was in a bloody fight against the PKK, Hizbullah used to emphasize the global Islamic community, ummah, circulating the writings of globally renowned Islamists such as Ayatollah Khomeini, Sayyid Qutb, and Ali Shariati. ${ }^{27}$

Published since 2008, Hizbullah's weekly newspaper Doğru Haber often depicts the movement activists as defenders of pro-Kurdish rights. In 2009, the movement launched a quarterly magazine, Banga Ḧeq Ji Kelhaamed: Kovara İslamî Çandîu Hunerî, published in two major Kurdish dialects that are common among Turkey's Kurds, i.e. Kurmanji and Zazaki. The very first issue of Kelhaamed starts with one of the writings of Said Nursi that is directed at the Kurdish community (originally published in a Kurdish newspaper in 1908).

Subsequent issues include articles that describe how Nursi's oppressed identity is symbolic of a larger oppression of Kurdish Muslims, specifically Hizbullah activists. In claiming Kurdish Islam, Hizbullah now presents notable Kurdish Muslim scholars like Ehmedê Hanî, Sheikh Said, and Said Nursi as inspirational leaders for their activism. The movement's 
Figure 7.3 Said Nursi as portrayed on the cover of Kelhaamed, Hizbullah's journal in Kurdish. Issue no: 8, Spring 2011

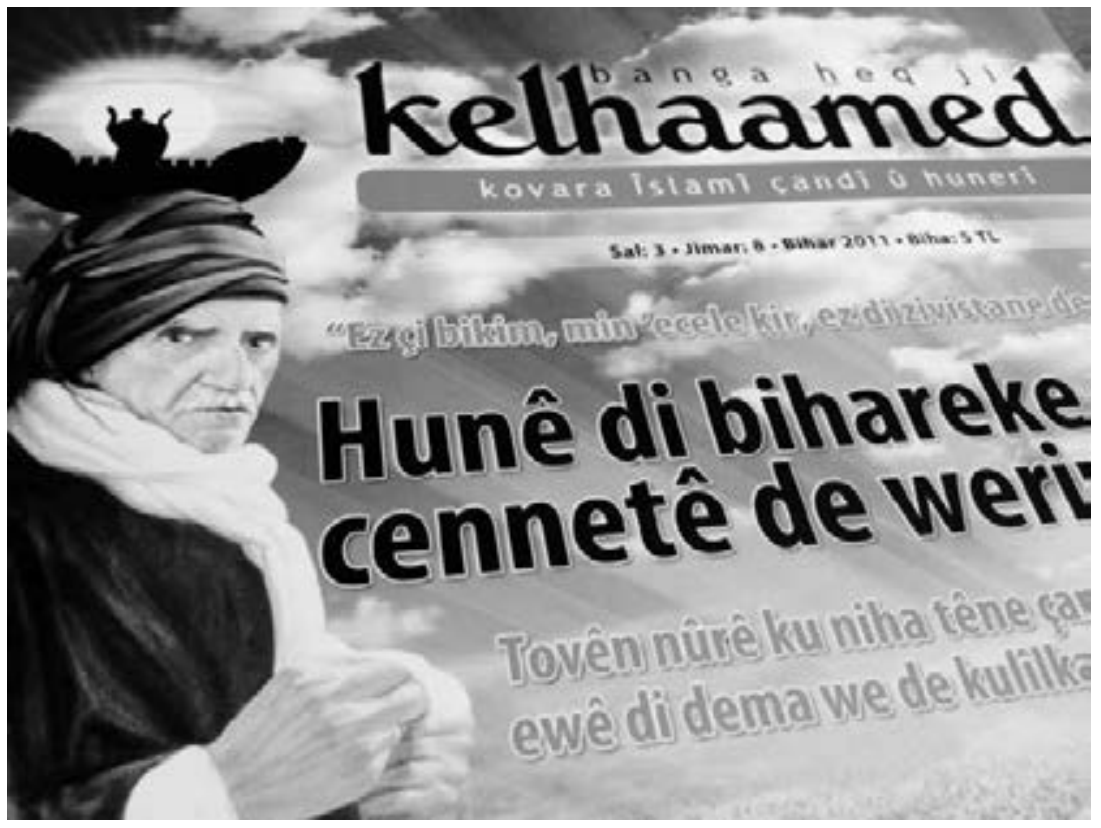

weekly Doğru Haber devotes one full page to the local Kurdish Muslim figures.

Said Nursi receives special emphasis in Hizbullah discourse for two major reasons. First, Hizbullah aims to repair its tarnished image as "violent jihadists" in the mainstream media. As a leading voice of non-violence, Said Nursi offers a clear public message that Hizbullah denounces violent methods in its struggle. Unlike the PKK's depiction of Nursi the rebellious, Hizbullah emphasized Nursi's non-violent activism as an oppressed (mustazaf) Kurd.

Second, claiming Nursi as their inspirational leader, Hizbullah activists engage with local Kurdish repertoires and therefore further gain legitimacy in public. This symbolic localization occurs through strategic subversion; Nursi's relation with other rival Islamic groups such as Gülen/Hizmet movement is questioned as Hizbullah depicts Nursi as “Kurdish.” Thus, Hizbullah re-constructs itself as defender of Kurdish Islam through the re-construction of Nursi and the de-legitimization of Gülen/Hizmet.

Hizbullah activists narrate how they have a deep spiritual connection with Said Nursi. In my conversation with Mahmut, who served ten years in 
prison for his links to Hizbullah, I learned that their spiritual connection has grown:

When we were jailed, our first religious discussion was based on Risale [i.e. Nursi's writings]; it was a great source of strength. So we pay much attention to the Risale. It is one of our fundamental sources. Other Islamic scholarly collections are of course important for us, but the Risale is an exceptional treasure. ${ }^{28}$

Hizbullah also reinterpreted the historic struggle of Said Nursi. For example, a publication about Nursi's life repeatedly refers to the community of Nursi followers (in the early years of the Turkish Republic) as Cemaat ("the Community"), which is what Hizbullah is called by its own members. The book often refers to students of Nursi as "mujaheeds" despite the fact that Nursi never employed such a term in any of his letters and books. It also refers to Nursi as "the Great Mujaheed" and Rehber ("the Guide") of his community - reminiscent of how Hüseyin Velioğlu is commemorated among Hizbullah members. ${ }^{29}$

Other Nur communities and Hizmet are quite skeptical about Hizbullah's narrations of Nursi. Many Hizmet activists feel that Hizbullah has no genuine interest in Nursi other than to exploit his image. Hizbullah, in response, often calls on other Nur communities to reread Nursi and to revisit his message, as Nursi, carrying "the intention of fostering enmity," was "the founder and leader of a movement that tried to establish and reinforce a communal union against the (Turkish secularist) regime." ${ }^{30}$

The call to revisit Nursi's message is especially directed at the Gülen movement. Pointing to Hizmet activists in our interview, for example, Hasan remarked:

They do not apply themselves to acting upon their readings [of Nursi writings]. Although $\ddot{U}$ stad $^{31}$ [Said Nursi] tried to bring forth his writings by undertaking all kinds of efforts, hardships, and suffering - and he tried his best to act upon his writings - these people now are very comfortable, and they have complete free-floating manners. I do not know how to say it, I mean, they are so at peace with the dominant power in effect; they 
show their acceptance of power holders through serving the status quo voluntarily ... These brothers, indeed, should re-examine themselves and find the Risale [Nursi's writings]..$^{2}$

Hizbullah's criticisms of Hizmet, however, do not stem only from their Islamic ideals. Nursi's ethnic Kurdish identity is often stressed to emphasize Gülen's Turkish roots. In this way, the reconstruction of Nursi occurs as a delegitimization of rival claims, and therefore, functions as a de-legitimizing force. In Hasan's words again:

Üstad's persistent representation as Sayyid, i. e. the descendant of the Prophet Muhammad, is another important issue. Üstad himself says that "I'm a Kurd, I'm not a Sayyid." He stresses this point insistently. He says that he might be considered a Sayyid in a spiritual way because of his servanthood to the Quran, but he was not a Sayyid in fact ... Yet, they persistently call him a Sayyid. Why? "He is not a Kurd," they mean; the issue comes to that point.

Thus, the evolution of Hizbullah from a global revivalist movement to a local Kurdish Islamic one should be read in light of the larger political context. Hizbullah's rivals have increasingly become active in the Kurdish Islamic sphere. On the one hand, Hizbullah's Islamic rivals in the Kurdish civil society such as the Gülen movement have gained momentum in the past decade. On the other hand, Hizbullah's Kurdish rivals, primarily the PKK-led ethno-nationalists, have increasingly utilized Islamic repertoires. Hence, Hizbullah's emphasis on Kurdish identity has helped to challenge its Turkish-Islamic rivals in the region; whereas, Hizbullah's Islamic claims have distinguished the group from many Kurdish ethno-nationalists. In this sense, local Kurdish Islamic symbols that enable the combination of these two identities have become very important for Hizbullah activists.

\section{HÜDA-PAR: Calling the Party of God in Kurdish}

The Hizbullah trial was finally concluded in Diyarbakır's Sixth Court in December 2009 with the decision to sentence all of the suspects to life in prison. Upon the Hizbullah members' appeal, the file was forwarded to the Supreme Court of Appeals. On January 4, 2011, in accordance with a recent

Author's interview, Diyarbakır. July 25, 2009. 
amendment to the Turkish criminal code that set a limit of ten years for the time detainees can be held without being sentenced in a final verdict, the eighteen members of Hizbullah were released from jail. ${ }^{33}$ Most of the released - including higher-ups Edip Gümüş and Cemal Tutar - have failed to check in with their local police stations as required by law. The Ninth Chamber later released a warrant for their re-arrest, but the police have so far failed to locate the fugitives.

Soon after these dramatic events, Turkish authorities closed Hizbullah's key civil society organization, Mustazaf-Der (Association for the Oppressed), in 2012. Mustazafin (sing. mustazaf) literally means "those who were weakened under the yoke of a brutal power" or simply "underdog." The word gained a new conceptual meaning during the 1979 Iranian Revolution, which is also known as "the revolution of mustazafin." In his writings, Ali Shariati, an Iranian sociologist whose works were embraced by the revolutionaries, identified the term "proletariat" with mustazaf, whereas the bourgeoisie was the equivalent of mustakbar, i.e. arrogant. ${ }^{34}$ Thus, the notion of mustazaf clearly developed a strong connection with global Islamic revivalism.

As their key organization was closed, Hizbullah activists decided to follow the path of Kurdish ethno-nationalists by forming a legal political party to be represented in the Turkish parliament. This ambitious project entailed further localization among Kurds. They picked a name for their political party, Free Cause Party, apparently for its acronym: HÜDA-PAR, which is "The Party of God" in Kurdish, equivalent of Hizbullah (The Party of God in Arabic). Hizbullah to HÜDA-PAR was not a simple name change from Arabic to Kurdish but a symbolic localization strategy: the colors of the party flag, green and yellow, express both Islamic and Kurdish identity. ${ }^{35}$

The next chapter explores competing narratives in the process of symbolic localization and conflict transformation. I discuss how competitor Kurdish activists engaged in narrative contests about illegal state operations against the Kurds. In order to gain visibility and legitimacy in public, all competing movements blame the "Turkish deep state" and those who collaborated with the state during the 1990s. The narrations of the deep state and its allies, however, are radically contested by competing movement narratives and bounded with the inter-movement rivalry dynamics in the region.

33 In Turkey, an inmate under arrest becomes a convict only after the approval of the Supreme Court of Appeals, which combines the functions of courts of cassation and appeals.

34 Taheri 2008: 217.

35 HÜDA-PAR's major events such as annual celebration of the Prophet's birthday have become more reflective of Kurdish national colors. See chapter 5 . 



\title{
8 Enemies of the "Deep State"
}

\author{
Narrative Contests and Symbolic Localization
}

The real rulers of a nation are undiscoverable.

- Felix Frankfurter

The state is an abstraction, only the people is a concrete fact.

- Karl Marx

It was a blazing summer afternoon in Diyarbakır and a few days before the crucial nationwide elections in 2011. As violence escalated in the city, so did questions. I ran into DIAYDER's main office to get a sense of new developments. My passion to understand the strategic logic of the alleged PKK attacks on a few imam-preacher schools led to my asking tough questions to Zahit Bey, the executive director of DIAYDER. The imam's cold response was not only a denial of PKK involvement, but also a challenge to my curious tone: "One would hardly know what is actually happening behind the scenes. Here, things are not the way it appears to one's eye."

The imam's reference to dark forces in everyday Kurdish politics has lately become an arena for cultural contestation. What has happened? Who were the perpetrators? Why? In the late 1980s, the implementation of martial law in the Kurdish-populated cities neither hindered the PKK insurgency nor protected local Kurds; instead, it reinforced a non-democratic environment in which violence became a part of everyday reality. The prolonged war between the Turkish military and the PKK provided a context for both illegal state operations as well as for false-flag operations of the PKK. ${ }^{1}$

As early as 1985 , the Turkish State started to make alliances with local tribes against the PKK and established armed Kurdish militias in villages, known as the village guard system (köy koruculuğu). Accordingly, tens of thousands of village guards were drafted from among local villagers. The State paid considerable wages to the village guards and supplied them

1 Spain's war against the Euskadi Ta Askatasuna (Basque Homeland and Freedom), ETA, had similar outcomes. Between 1983 and 1987, the Spanish government illegally sponsored death squads, known as Grupos Antiterroristas de Liberación (Antiterrorist Liberation Groups), GAL, to fight the ETA. See Woodworth 2001. 
with weaponry. ${ }^{2}$ The village guardianship system, however, was open to abuses and did not mitigate increasing insecurity in the region. ${ }^{3}$ Hizbullah's armed struggle with the PKK (1991-1996) further worsened the anarchic atmosphere.

In the early 1990s, thousands of Kurds simply disappeared because they were alleged PKK sympathizers. Stories and rumors circulated among local Kurds as dead bodies and tortured corpses were found on the outskirts of the cities. ${ }^{4}$ Assassinations of pro-Kurdish politicians skyrocketed. ${ }^{5}$ Regardless of different and often conflicting narratives, a consensus has emerged about the existence of illegal, dark, and secret state operations and counterterrorism units that targeted Kurds, popularly known as the "deep state" in Turkey.

This chapter analyzes how the notion of the "deep state" has become a cultural construct that has acquired a life of its own. Each rival movement has contributed to the public vilification of the "deep state" in order to resonate more with local Kurds. In other words, the rivals have pursued a strategy of legitimacy building in public as they narrate the deep state's operations to exterminate Kurds. The activists ardently engaged in theorizing about the Turkish state as they condemned their rivals for being co-opted by "evil" elements of the state. In these competing narratives of the history, the rivals contested what actually happened in the past, who was co-opted by the state, the Turkish state's security policies, and even the nature of the state itself.

Analyzing narrative contests, I suggest that meaning-making processes of Kurdish activists are not separable from the dynamics of social movement competition in the region. ${ }^{6}$

2 For the village guard system, see McDowall 1997: 422; Romano 2006: 82.

3 The tribal structure of Kurdish society also contributed to abuses in the village guard system. Some tribes that entered the system misused their new authority and arms to drive other smaller tribes from their lands. See McDowall 1997: 422.

4 According to Insan Hakları Derneği, a secular leftist human rights association, there were more than 200 places that were used by counterterrorism squads of the Turkish military to torture and execute Kurds. In these mass graveyards, the death toll is about 3,00o people. See, the interactive map: http://www.ihddiyarbakir.org/Map.aspx, Accessed March 4, 2012. The total number of lost and murdered Kurds, however, is more than 6,ooo. See, IHD 2009. The death toll is only comparable with notorious examples of state-led violence in Argentina and Chile in the late 1970s, known as the "dirty wars." In Argentina, 10,000-15,000 died or disappeared; in Chile, the estimated toll was 4,0oo. See Loveman 1998: 486.

5 In just two years, between October 1991 and October 1993, fifty-four Kurdish politicians and activists were murdered and hundreds were threatened with blackmail. See Oran 2010: 47-48. Most cases still remain unsolved.

6 Social movement studies are increasingly paying special attention to the storytelling practices of activists. Among leading works are Polletta 1998a, 1998b, 2006; Davis 2002. Scholars 


\section{The "Deep State" and Kurds}

People began to hear the term "deep state" after a traffic accident in the small town of Susurluk in northwestern Turkey in 1996. Three of the four passengers in the luxury car died at the scene. Revelation of the occupants' identities became a milestone event as it publicly revealed a peculiar network for the first time. Those who died were (1) an ultranationalist hit man on Interpol's Red list, (2) his mistress who carried a fake identity certificate, and (3) the former deputy head of the Istanbul Police Department. And finally, the survivor was a deputy in the Grand Turkish National Assembly and the leader of a Kurdish village guard clan. The Susurluk accident triggered a massive public reaction and introduced a new political term derin devlet, the deep state.

Fast forward to November 2005 when a defector from the PKK employed as an informant by the security forces and two officers of the local gendarmerie bombed a local bookstore in Şemdinli, revealing that some army officers illegally target PKK sympathizers. ${ }^{8}$ The state prosecutor linked high-ranking military officers to the incident, including General Yaşar Büyükanit (later the chief of the general staff) who had served in the region in the late 1990s. The prosecutor's indictment pointed out that the bombing "was part of a series of similar attacks intended to provoke the security forces into a clampdown on the restive Kurdish region that would then unleash European criticism and jeopardize Turkey's hopes of joining the EU."9

This particular incident, popularly referred to as the Şemdinli affair, was followed by other revealing events, and consequently, five different illegal clandestine organizations were detected that have ties with some army

note three distinct features of narratives: (1) some are a form of selective appropriation of past events and characters, (2) others provide a temporal order of events, and (3) some weave events and characters into what is called the "relationality of parts" or "emplotment" (Ewick and Silbey 2003: 1341). Narrative accounts select certain events in the past as building past, present, and future in a consequential way in order to clarify "the point of the story" (White 1987).

7 In the early 2000s, characterizations of state-mafia relations in popular Turkish soap operas and television series such as Deli Yürek (the Reckless Heart), Kurtlar Vadisi (Valley of the Wolves), Yılan Hikayesi (Snake Story), and Alacakaranlık (Twilight) further contributed to popular discourse about shadowy figures within the state.

8 Aytar 2006: 6-7.

9 Turgut 2006; quoted in Kaya 2009: 104. The prosecutor Ferhat Sarıkaya also accused General Büyükanıt of attempting to influence the judicial process as the general had commented that he knew the alleged bomber officer personally and that the officer was a "good boy." The prosecutor was disbarred by the Supreme Board of Prosecutors and Judges (Hakim ve Savcllar Yüksek Kurulu) on the grounds that his indictment was faulty. 
officers and ex-army members. ${ }^{10}$ The events hinted at the existence of shadowy formations within the security forces and raised questions about the legality of the measures used in fighting terrorism with respect to citizens' rights. In the words of Christopher De Bellaigue in The New York Review of Books,

Some members of the armed forces, afraid of losing the prestige, political autonomy, and big budgets that they have enjoyed since the PKK rebellion gained momentum in the late 1980 , do not want peace at all ... The relative freedom with which Öcalan's (the captured leader of the PKK) lawyers have been able to pass on his messages has led some to suspect that he is cooperating with his captors - that he has defected, in effect, to the 'deep state."1

De Bellaigue's comments found echo in everyday Turkey, especially after one particular illegal clandestine group became publicly known: Ergenekon.

Named after a mythical valley in Central Asia, ${ }^{12}$ Ergenekon was allegedly supported by counterterrorism units within the Turkish military such as JITEM (Gendarmerie Intelligence and Anti-Terror Struggle). As a response to the PKK attacks in the late 1980s, Turkey declared eleven provinces in east and southeast Anatolia to be in $O H A L$, "Emergency Rule Law," governing the region by martial law. ${ }^{13}$ Enjoying the independence from checks and balances by the civil authorities, some of the army members became involved in a "dirty war," including forming some illegal death squads that killed several thousand community leaders and human rights activists for allegedly being PKK sympathizers, waging false-flag terrorist attacks, and forcing hundreds of thousands to evacuate their villages. ${ }^{14}$

JITEM units were heavily recruited from former members of the PKK, who provided information in return for immunity from prosecution or reduced jail sentences. As Gareth Jenkins notes,

In addition to gathering intelligence, JITEM units would detain, interrogate, and frequently torture and execute suspected PKK members.

10 Radikal 2006.

11 De Bellaigue 2007: 37 .

12 In the legend of Ergenekon, a she-wolf rescued the Turkish nation in a most desperate situation in Central Asia. The Turkish republican elite reproduced the Ergenekon myth in its early years, trying to establish a secular nationhood disconnected from the Ottoman past. See, Türköne 2009.

13 From 2000 onwards, after the EU negotiation talks began, the number of provinces in the $\mathrm{OHAL}$ was gradually reduced till its final abolition in November 2002. For details, see Chapter 4.

14 Van Bruinessen 2004: 12; Kaya 2009: 100. 
JITEM units also targeted those who were believed to be merely Kurdish nationalists, assassinating journalists and intellectuals and bombing the offices of publishers and Non-Governmental Organizations (NGOs). ${ }^{15}$

In June 2007, a legal investigation into the Ergenekon organization was filed. The state prosecutors defined Ergenekon as a collusive terrorist organization within the Turkish state, rooted mainly in the Turkish armed forces. ${ }^{16}$ The type of network was reminiscent of the notorious Italian counterterrorism unit, Gladio, and therefore, the state prosecutors' indictment linked Ergenekon with NATO's secret stay-behind armies in member countries against a potential Communist invasion.

Despite disputes between pro-Islamic and pro-secular constituencies about the Ergenekon case, major political players in the Southeast, namely the pro-Kurdish DTP and the AKP, have concurred that the Ergenekon has used brutal violence against the Kurdish population. As the Ergenekon's covert operations against the Kurds became public, criticism of the deep state increased in the region.

\section{The Rival Movements and Competing Narratives on Ergenekon}

The question "What is Ergenekon?" posed in a nationwide poll saw the majority of AKP and DTP voters defining Ergenekon as an organization that is "responsible for all mysterious violent acts. ${ }^{{ }^{17}}$ The DTP leader, Ahmet Türk, maintained that the Ergenekon conspiracy was directly tied to the Kurdish question in Turkey:

Wherever this organization [Ergenekon] grew, it was within the geography of Kurdistan. Where did the arrested generals do their duty? Within Kurdish geography. Against whom did they direct their operations? The Kurds. According to official statistics, there are 17,00o unsolved committed murders. Ninety percent of them were committed in the Kurdish regions. People were murdered savagely and thrown into acid pits. They were taken from their homes in the middle of the night and killed. They were forced to eat feces and underwent unimaginable torture. ${ }^{18}$ 
Türk further criticized the AKP for its failure to adequately investigate Ergenekon operations in Kurdish-populated regions. The AKP officials, on the other hand, charged the DTP for its lack of support in their fight with the status quo regime that is responsible for the Ergenekon-like organizations.

Involved in a never-ending process of meaning-making, rival Kurdish activists of the PKK, Gülen, and Hizbullah have vilified the "deep state" through telling stories. Their narrations, however, have not been freefloating performances. Competition among the rival activists has led them (1) to engage with the notion of deep state to the extent that they could exploit the discursive opportunity in the best way possible, and (2) to build their legitimacy in the public eye as they emphasize the deep state's collaboration with rivals.

I call rival movement activists' story-telling efforts to re-construct their identities through the negation of their competitors a process of "social movement distinction." As a form of strategic subversion, the social movement distinction is a never-ending discursive performance of selfconstruction (Re-construction) that can be realized to de-authenticate the rivals (De-legitimization). In the Kurdish case, the rival activist narratives claim their bona fide Kurdish-ness (Re-construction) through condemning their rivals' collaboration with the deep state (De-legitimization).

Thus, narrative contest is a form of social performance, entailing a "feeling for the game" that the social movement actors play. It is a highly developed cultural game that has two components: (a) story-telling as a form of mimicry and (b) competition or agon, i.e. warfare. As Marie Maclean puts it,

In the normal narration, while there is always a narrator, we are frequently left to deduce the possible reactions of the narratee from the strategies of the text. In the narrative contests, however, the double nature of the narrative contract is actualized because each performer is seen in a double role. Apart from explicitly judgmental statements, each competitor also gives an implicit opinion of the previous narration by the tale he or she chooses to tell and the manner of telling it. So each is not only actor but audience, and simultaneously both counsel and judge. ${ }^{19}$

In what follows, I analyze the rival movements' reputation work through narratives. 
Figure 8.1 Public responses to question about the existence of the deep state (Conducted by Metro Poll in January 2009)

\section{Do you believe that Ergenekon exists?}

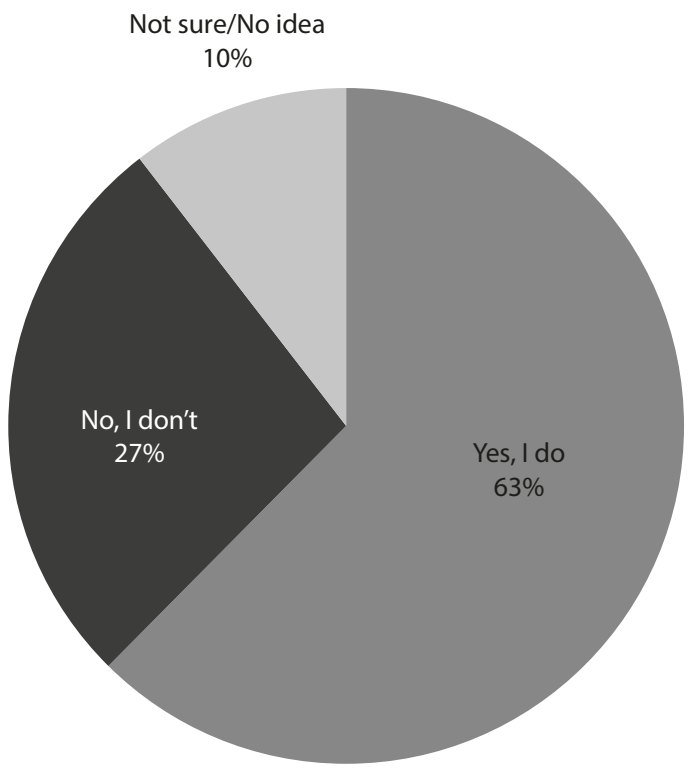

\section{The Gülen/Hizmet as Enemy of the Deep State}

The Turkish military's intervention in politics on February 28, 1997, popularly called the post-modern coup, initiated a process "of monitoring, controlling, and criminalizing all Islamic activism" including the Gülen movement. ${ }^{20}$ The February 28 process came as a great shock to Hizmet activists. For the first time in the movement's history, activists were publicly ostracized, charged, and discriminated against for allegedly being enemies of the state. ${ }^{21}$

20 Yavuz 2003: 277. In the February 28 process, two political parties were banned because of their allegedly Islamist roots; about a thousand military officers were removed from their posts for similar reasons; some corporations were labeled 'green capital' and discriminated against; hundreds of Qur'an teaching centers were closed; and thousands of students were expelled from public and private universities because of their adoption of the headscarf. See, Gürbüz 2oog; Taş 2011.

21 The state security court prosecutor opened a court case against Fethullah Gülen by demanding the death penalty. For the details of the case, see Harrington 2011. 
Fethullah Gülen had to go into exile in the United States because of extreme pressure.

In 2004, the movement's Samanyolu channel launched a TV series, Şubat Soğuğu (The Cold February), narrating the February 28 process through a fictional account. The Cold February (2004-2006) depicts shadowy forces gathered around a clandestine group of the power elite known as Cemiyet (the Committee) and how they effectively operated to shape state policies in the 199os. The Committee, which includes both outside/foreign elements and domestic members, appoints a key bureaucrat (Mehmet Aziz Tarman) as the chief executive to control the State's national security policies through manipulations, provocations, and the construction of mass hysteria. As the ultimate power behind the extra-judicial activities in the country including the major atrocities in the Kurdish-populated Southeast, the Committee has strong relations with outside "hostile" forces abroad. In this sense, The Cold February resonated with local discourses among Kurds as well as Turks because it reproduced multiple and conflicting local meanings that are primarily shaped by people's own lay theories.

The Gülen movement's narrative of the Kurdish issue was a public challenge to the official state discourse. As the civil society competition escalated after the 2007 elections, the Samanyolu channel launched another TV series, Tek Türkiye (One Turkey), this time exclusively for narrating the Kurdish issue.

One Turkey tells the story of a young, idealistic doctor called Tarık who travels to the Southeast from Istanbul. Planning a short trip, Tarık aims to help local people who suffer from the war between the Turkish state and the PKK rebels. Tarık's trip turns into a long journey when he learns that he was born in the village that he visited in the Southeast, so he is a Kurd, not a Turk. Although One Turkey does not mention the Gülen movement, Tarlk's persona clearly represents a Hizmet activist in the region. Tarık is an observant Muslim Kurd who has a high level of education. His original Kurdish identity functions as a representation of the bona fide Kurdishness of Hizmet activists (Re-construction). Through Tarık's emphasis on his Islamic identity, a recognition of his Kurdish-ness, his unyielding defense of the land of Turkey against PKK guerillas, and his community service as a doctor (and then local governor in later episodes), viewers get a concrete message: Separatism is not a solution for the problems in the region; instead, investing in the education of the youth and Turkish-Kurdish unity around an Islamic identity could prepare a better future. 
The most striking feature of One Turkey is its constant reminder of the deep state. The series depicts some powerful, ill-intentioned figures who employ covert operatives who are involved in provocative secret operations to incite hatred among local Kurds against the state. Reminiscent of the Committee in the Cold February series, these figures are not visually recognizable but could be heard by the viewers. Their forum, called Karanlık Kurul (the Dark Committee), often collaborated with some of the Kurdish guerilla leaders (representing the PKK), some radical Islamic groups (representing Hizbullah) as well as some high-level Turkish army officers who specialize in counterterrorism (representing the JITEM, Gendarmerie Intelligence and Anti-Terror Struggle). The show, thus, narrates how the leaders of the PKK and Hizbullah collaborate with the deep state for their selfish interests and sell out the cause of Kurdish people's well-being (De-legitimization).

One Turkey suggests two pictures of the Turkish state for its audience: (1) ugly elements of the state ("the deep state") that are not part of the genuine Turkish state, and (2) the real Turkish state that embraces its Kurdish population as equal citizens. Consider the following occasion in the eighty-sixth episode of the show: After a legal interrogation, two former members of the PKK (who were not involved in criminal acts and who later turn themselves in) were set free by the Gendarmerie station. As they are about to leave, an officer from a specialized unit (JITEM) wants to re-interrogate them. The colonel who administers the Gendarmerie station insists that their interrogation was held and they should be allowed to leave. The dispute continued as following:

The JITEM officer: Your benign interrogation techniques would not work for them! Let me have a chat with them. You'll be surprised to see how eager they are to talk.

The Colonel: That's enough for them to be tortured by the terrorists. Don't torture them!

The JITEM officer: Don't be kindhearted, commander. You'll cry a lot then!

The Colonel: Do not touch them! I know what you guys wanna do. Your sole job is to make the people of this land into sworn enemies of their fellow citizens and their state. But don't get too excited: Your dynasty will fall apart soon.

The JITEM officer: Who do you think you are! Beware of your rank. You could never reach us. Know your limits or we will put you in your place. 
The dialogue presents two conflicting approaches to the Kurdish rebels. The Colonel represents the authentic Turkish state's position: conducting business within the legal boundaries, sympathetic towards its Kurdish citizens, and cognizant of abusers who work within the state apparatus. On the other hand, the JITEM officer represents the dreadful face of the Ergenekon, the Turkish deep state: torturing its Kurdish citizens, recruiting from former members of the PKK, who provided information in return for immunity from prosecution or reduced jail sentences, and deliberately escalating the hatred between Turkish and Kurdish communities in order to strengthen their militaristic authority.

Another occasion in the same episode includes a Kurdish girl's regretful account before a gentle school teacher who was also previously a rebel in the mountains:

I made a lot of mistakes. I was rebellious against my people and my state. But now I realize that the state is not only those who do bad things to us. I supposed that they were the state. In fact, it turned out that they were bandits who had infiltrated the state. The real state, indeed, has been you and us.

The girl's account highlights the main idea in the One Turkey series: many Kurds who were ignorant about the deep state and its activities condemned the Turkish state; now it is time to realize that there was a bunch of criminals acting in the name of the state.

In the Gülen activists' narrative, the very definition of the state remains a symbol of unity among its Turkish and Kurdish constituents, whereas the definition of the deep state refers to a dark relationship between some elements within the state and radical elements in society. Many episodes of One Turkey narrate how the Kurdish guerilla leaders (representing the PKK) are in close connection with the deep state in order to facilitate further recruitment to their party (De-legitimization). References are made to the Turkish state negotiations with Abdullah Öcalan, the captured leader of the PKK, in a way that implies the Kurdish ethno-nationalists' compromise with the deep state in return for the PKK's organizational survival. The message is clear: the defenders of Kurdish ethno-nationalism are indeed prioritizing their organizational survival over the Kurdish people's well-being; therefore, they have sold out. In a similar vein, some episodes depict Hizbullah as the spawn of the deep state conspiracy in order to boost the militaristic hegemony in the region (De-legitimization). 


\section{The PKK: "The State wants to sweep its filth under the carpet!"}

Soon after his election with the pro-Kurdish party ticket as the mayor of Diyarbakır, Osman Baydemir removed the Turkish Republic's founder Mustafa Kemal Atatürk's statue from one of the city's main squares. Then he erected a statue of Musa Anter, a prominent Kurdish writer and activist, who was killed as part of a wave of 'unknown-assailant murders' in 1992. It was a powerful attempt to shape 'geography of memory' by drawing public attention to the Ergenekon atrocities. ${ }^{22}$ As the pro-Kurdish party DTP leader Ahmet Türk put it,

We feel that the Ergenekon issue is very important for the future of Turkey and for transparency in politics. I believe that if all dimensions of the Ergenekon issue are made clear, the Kurdish and Turkish people will better understand one another. It is important to make clear the efforts of Ergenekon to put the Turkish and Kurdish people at loggerheads ... The source of the Ergenekon conspiracy was the Kurdish question. The origin, nurturing, and growth of the Ergenekon organization were in the Kurdish region. The operation they perpetrated in the Kurdish region consolidated their power and made them a stronger organization. ${ }^{23}$

The ethno-nationalist narratives on the Turkish deep state, however, were bound up with the inter-movement competition structure. Pro-Kurdish politicians expressed their deep concern about the investigation held by the pro-Islamic AKP. Emine Ayna, a leading pro-Kurdish party deputy, stated their strategic approach as she commented on the pro-Islamic actors' claims about the Ergenekon case:

Our position is clear. Whatever the claims of the Ergenekon case that are exposed, Kurdish intellectuals and Kurdish politicians will realize that the issues are not as they appear and, indeed, the Kurdish intellectuals and politicians will analyze the Ergenekon case and will take action. ${ }^{24}$

Ayna's frank statement illustrates the difficulty and elasticity of this contested issue as a consequence. The competing activists could speculate on constantly developing the Ergenekon case as they learn about their rivals' discourses. 
Kurdish ethno-nationalists depict the deep state as the Turkish state itself. For example, Ahmet Türk argued that Ergenekon was not comprised of individuals who had worked for the state but by individuals within the state. Ergenekon's atrocities, exclaimed Türk, were perpetrated "by the state itself." "If you cut off the tail of a snake without crushing its head, it becomes more dangerous ... The 'covered' face of the state wants to sweep its filth under the carpet." ${ }^{25}$ Likewise, Songül Abdil, the mayor of Tunceli from the DTP, narrated the atrocities of the Turkish state and its armed forces as she maintained that Kurds were hardly surprised by the horrific tactics of the Ergenekon:

In 1938, during the massacre in Dersim [Tunceli is usually called Dersim by Kurds], thousands were killed ... They stabbed our women's stomachs with bayonets, extracted their babies, and threw them into the Munzur River. $^{26}$

Abdil's equation of Ergenekon with the Turkish state and its military does not reflect her opinions solely. In my field interviews, I heard similar narrations. Ararat, an activist who works for the Kurdish daily Azadiya Welat, claims that Ergenekon was the last attempt of the Turkish state to eliminate Kurdish resistance:

In fact, we should ask the question why the state had needed the Ergenekon in the first place, and later, could not get along with this organization. The Ergenekon was needed since the Kurds have come to a certain point in their democratic struggle, have become powerful; and then, it became apparent that they cannot be resisted through legal means. In this sense, the state has chosen to establish illegal squads within its apparatus. I mean, the Ergenekon is not something separable from the state or governments; therefore, we do not see it as a component or section [of the state]. ${ }^{27}$

Ararat's account portrays the deep state as the illegal "dirty" face of the state, and PKK activism is viewed as a successful challenger that drives Turkish state policy (Re-construction). Moreover, Ararat criticizes the party in power, the AKP, and holds it to be complicit in the crimes despite the pro-Islamic AKP's claims to fight against Ergenekon (De-legitimization). 
Another activist, who works to unionize pro-Kurdish teachers in Urfa, describes how he sees pro-Islamic actors as complicit in the crimes of the state:

According to my own perception and our communal perception in general, the Ergenekon case is an operation of the state to purify itself ... In fact, the Ergenekon case is a result of negotiation between the AKP and the deep forces in Turkey ... Those arrested [in the Ergenekon case] were the main figures who had implemented violent policies to solve the Kurdish question for years. First, they were eliminated due to their failure to solve the Kurdish question despite their employment of all sorts of violence ... Second, the operation [to eliminate them] was an outcome of cooperation between the AKP and the Turkish Armed Forces. What kind of cooperation? The AKP is told to attack those hawks by political means ... In return, the AKP demanded their support; assuring them it could diminish Kurdish people's interest in the PKK and the DTP by playing the religion card. ${ }^{28}$

The union activist's portrayal of the cooperation between the pro-Islamic actors and the state is remarkable in two ways: First, he interchangeably uses "the deep forces" and "the Turkish Armed Forces" through negative connotations as he narrates their violent stance on the Kurdish issue. Thus, similar to Ararat, he does not distinguish them as separate political formations. In this regard, he also reiterates the pro-Kurdish activists' opposing position vis-à-vis the state (Re-construction). Second, he accuses the AKP of being co-opted by the state in terms of solving the Kurdish question. Therefore, rival Islamic-Kurdish identities are now in play to crush the PKK mobilization (De-legitimization).

For many Kurds, the PKK leader Abdullah Öcalan is a powerful storyteller. Öcalan warned Kurds that the criminalization of Ergenekon is a strategic choice that is linked to current transformations in the Middle East. The real threat, he concluded, is American-led "soft Islam," the AKP and the Gülen:

The United States had a major influence on the elimination of Ergenekon. Having a new plan for the Kurds, the US wanted to realize its aims. Yet, through active resistance, these people [the Ergenekon convicts] did not let the US realize its Kurdish project. The US does not want the PKK 
to remain as it is, and therefore they develop conspiracies (against us). Those who were detained in the Ergenekon case are professional soldiers who have been trained by the US since the 1960 s as intelligence and counter-guerilla officers. The US told them, "You screwed up!" and later put them out with the garbage. Now, the US wants to realize its (Kurdish) project through "soft Islam." ${ }^{29}$

Öcalan also adds "radical Islam" as an element of this project, claiming that Hizbullah has been nurtured into "a ready to use force against Kurds" in the hands of the Turkish state. ${ }^{30}$ Öcalan's accounts often refer to Hizbullah as the Hizb-i Kontra (Party of the Counter). Given the fact that kontra is employed to refer to counterterrorism/counter-guerilla groups, Hizb-i Kontra (Party of the Counter) labels Hizbullah as collaborators of the counter-guerilla forces that attack the PKK. ${ }^{31}$

\section{Hizbullah: "We're the Victims of the Deep State!"}

One of the first publications of Hizbullah was Eşreften Esfele (From the Most Honorable to the Most Shameful). Written as fiction in the form of a novel, ${ }^{32}$ Eşreften Esfele depicts Hizbullah as a group of young Muslim Kurds who are organized for the well-being of their local community. The novel describes "illegal" and "shameful" operations conducted by some undercover agents in order to damage Hizbullah activism and its rising reputation among the Kurds. The story ends with Hizbullah's kidnapping of a key undercover

29 For the full talk, see Öcalan 2009b. Öcalan's talks from his cell are regularly recorded by his lawyers and widely distributed in the Kurdish community as Görüşme Notları, i.e. the Meeting Notes. The PKK- affiliated online platforms such as http://www.rojaciwan.com/ and http:// www.firatnews.com/ provide the Meeting Notes in full.

30 Öcalan 2008a, 2009d, 2011a.

31 Öcalan depicts complex relations between "soft-Islam" and Hizbullah, even calling the AKP the official form of Hizbullah (Öcalan 2008b). His narratives put the AKP, the Gülen movement, and Hizbullah on one straight line that has been compromised by the deep state, which he sometimes calls the "Gladio." "Among the Turkish army, there were those who accepted the AKP's power in Turkey and those who did not. Cooperating with those who accept- and in fact they have been those who represent the NATO Gladio-, the AKP went to eliminate the other segment of the Gladio who started to operate independently. I mean, the Gladio was not eliminated totally; instead, an agreement and a negotiation were held with one part of the Gladio." See, Öcalan 2011 b.

32 Among Hizbullah's fictional novels are Konuş! Yoksa ... (Speak Up! Otherwise ...), İstanbul: İhlas Yay. 2004 and Can Laleler Solmasın (Don't Let Lovely Tulips Wilted), İstanbul: Dua Yay. 2009 . 
state agent, Zülküf Dogan, and subsequently the capturing of many others. After his abduction, Zülküf's muttering to himself, in fact, summarizes the major themes in the novel:

You're finished now. You who had many innocent people tortured for no reason! You who had people jailed and who made their families miserable! You who were spreading seeds of doubt and disunity that caused people to cease to care for the Brothers [Hizbullah]; who was inculcating Devilinspired thoughts that led them to renounce Islam! You who sexually abused little children; and you, who besides being a spy, has turned others into spies! What a pity for you!

The confessions of Zülküf aim to give the main message to the reader: Hizbullah did not kidnap and murder random civilians; instead, those killed were undercover agents of the Turkish state.

The public discussions of the Ergenekon case have provided Hizbullah activists with a discursive opportunity. An online Hizbullah publication claimed that its earlier description of "the dark and dirty plans of the Kemalist regime ${ }^{\prime 33}$ referred in fact to the Ergenekon operations in the region ${ }^{34}$ Depicting the Turkish secularist regime as the foundation for the deep state, Hizbullah activists do not really distinguish the Turkish state from its deep entities. As one of the activists told me, the deep state is "a component of the state itself." ${ }^{\prime 35}$

Hizbullah activists narrated how they were both victims of the deep state as well as the bona fide Kurdish challenger against the deep state (Reconstruction). Often portrayed in the 1990s as an armed machine of the Turkish deep state aimed at eliminating the PKK, they are quite disturbed. "For

33 Hizbullah activists use "the Kemalist regime" and "the secularist regime" interchangeably to refer to the Turkish state regime.

34 The anonymous document further claims: "From its very establishment, the Kemalist regime has been a system that strives to exist at the expense of its own people, a system that never considers the nation's values and wishes ... We should emphasize that the roots of the Ergenekon-like organizations go back to societies such as the Union of Committee and Progress [İttihad ve Terakki], which has been active since the foundation of the Kemalist regime ... The Community [Cemaat] of Hizbullah has become the target of the Ergenekon-like groups since its earlier days of widespread and effective public activism. We could easily claim that there is no community in the world that struggled with the Ergenekon-like organizations and got results as much as the Hizbullah did. This fact has incited enmity against the Hizbullah at its peak." See Anonymous 2008.

35 Author's interview. Istanbul, June 5, 2009. 
us, to collaborate with the Ergenekon is disbelief" said Hasan, who was sent to prison for being a Hizbullah member, complaining about the allegations. ${ }^{36}$

Hizbullah's military flank leader Cemal Tutar narrates how the PKK and the Gülen defame Hizbullah. Tutar's claims represent the movement's overall stance: the overwhelming majority of the Hizbullah's public statements portray the PKK and the Gülen as corrupt because of their dark relations with deep forces of the system (De-legitimization).

A passage from Tutar's statement illuminates how the PKK is depicted by Hizbullah activists:

Everywhere in the world, the enemies of Islam who do not want to acknowledge successful Islamic movements attempt to slander them and thus devalue their victories. Nowadays, Al-Fatah's efforts to cast a shadow on the achievements of HAMAS in Palestine - and its alienation from its own people so that it could even cooperate with Israel - are not different from the wrongdoings of the PKK. It's because [similar to the PKK], in order to diminish the people's support, Al-Fatah claims that HAMAS was established by Israel. For this reason - as well as for many other reasons - one could strikingly see how the PKK and Al-Fatah are identical. ${ }^{37}$

The narration of the Israeli-Palestinian conflict is purposeful because mainstream Kurdish public opinion perceives HAMAS as a legitimate defender of the Palestinian people. In this way, Hizbullah is depicted as a popular resistance movement as unyielding as HAMAS, whereas the Kurdish ethno-nationalists are portrayed as having dark relations with the system similar to Al-Fatah (Re-construction and De-legitimization). ${ }^{38}$

$3^{6}$ Similar statements are made by other activists who use pseudo-names to publish on Hizbullah's website:

“To mention Hizbullah's name together with the Kemalist regime's intelligence office is the greatest insult to our community. The Kemalist state uses many organizations including nationalist, leftist, and fascist since they are ideologically and politically open to be utilized ... Yet, Hizbullah is quite different in terms of its belief system and organization structure ... It can never be used by any power. First of all, the political thought, ideology, and belief of the Hizbullah perceive the Kemalist regime as a system of infidels. Hizbullah not only believes that the regime should be destroyed but also takes action to smash it." (Nuhoğlu 2011).

37 Tutar 2009: 82.

38 In our interview, one of the prominent Hizbullah singers told me that they especially seek to raise consciousness about the plight of the Palestinians through their songs. The most popular albums of the Group Özlem (the movement's music agency) such as Bu Ne Sessizlik (Defeaning Silence) and Vuslata Özlem (Yearning for the Reunion) have several songs in support of the cause of HAMAS and Palestine. Author's interview. Istanbul, June 7, 2009. 
In a similar vein, an article published in Hizbullah's weekly Doğru Haber describes Gülen as a part of "a MOSSAD-linked deep project" against Hizbullah:

In recent years, Gülen-swayed missionaries have been rushing into the region in order to subdue Kurds, or even make them monkeys. Backed by Pennsylvania [where Fethullah Gülen is living], they are certainly part of a Zionist international plan that targets Kurds. Everybody and his brother knows about the notorious plans to launch a Kurdish establishment as Israel's servant in order to shape the future of Kurds in accordance with Israeli interests. ${ }^{39}$

\section{Narratives in Conflict Transformation: Reputation Work and Symbolic Localization}

How do narrative contests contribute to the shift in the violent ethnic conflict toward non-violent political persuasion in the region? In their study of Israeli-Palestinian conflict, Daniel Bar-Tal and Gavriel Salomon argue that narratives are motivational tools to solidify group identity and dehumanize the enemy. Thus, narratives help to prolong injustice and ethnic conflict. Transformation of the conflict, they suggest, depends on changes in collective narratives. The first step in this direction is for people to learn about the other side of the story, giving legitimacy to competing narratives. Willingness to listen to the other, however, should come from the stronger party first. ${ }^{40}$

The Ergenekon investigation provided an unprecedented opportunity for Turkey to face its dirty war in the Southeast. As victims of the secularist military regime, the pro-Islamic AKP and Hizmet supported the investigation. Public criticisms of the military opened Pandora's Box: the Turkish constituency began to hear competing stories about "terrorists" for the first time in such a degree. Having roots in both Turkish and Kurdish constituencies, these pro-Islamic actors helped to deminish the ruthless Turkish nationalist stance that long imposed "narrative violence."41

In my fieldwork, I observed that Turkish Hizmet activists spoke highly of the drama series One Turkey whereas Kurdish Hizmet activists were more

39 Atak 2011. Doğru Haber has long called Gülen-affiliated media "Fesat Medya Grubu," (Corrupt Media Group) pejoratively. For allegations on TV show One Turkey, for example, see its issue no: 54, April 10-16, 2009.

40 Bar-Tal and Salomon 2006: 39; Pappé 2006: 198.

41 Cobb 2013: 29 . 
critical of the show. Feeling enlightened about the Kurdish issue, a Turkish activist asked a leading Hizmet spokesperson who is ethnically Kurdish, "Do they [Kurds] not watch One Turkey, to realize what is going on behind the scenes? It should be nominated for the Oscars."

Although a Kurdish audience would find such a question orientalist and disturbing, his questioning tone was more an expression of his sympathy for Kurds. Through One Turkey, he recognized that some Kurds were "forced" to join the PKK because of outrageous attacks by the "deep state" during the martial law era. Thus, the "attribution of subjectivity," that is seeing the other as a victim of structural forces, enabled the Turkish constituency to be willing to hear more about alternative narratives about the conflict.

The pro-Islamic activists' meaning-making processes, however, are not constructed in a vacuum. Public criticisms of the deep state have provided a "discursive context" to interpret their positions vis-à-vis the Turkish State..$^{42}$ Narratives have helped to situate all social actors in the new game - nonviolent competition in the civil society. What should be remembered? How? From Hizbullah's novels to ethno-nationalist municipality projects, narratives play a huge role in symbolic localization of competitor Kurdish activists. Narrative contests are, in fact, an essential part of reputation work: rival activists re-constructed their self-image through "distinction" among other Kurds. They call Kurds to build trust on their bona fide Kurdish movement by harming the reputation of their competitors. Thus, there is the process of social movement distinction, a constant discursive performance of articulation, re-appropriation, and negation.

Transforming the ethnic conflict, rival Kurdish activists are now "reputational entrepreneurs" ${ }^{144}$ thanks to the interpretive and representational character of their narratives. Competitors in a narrative contest are not supposed to carve out the details of their message since their narrations are constructed through images that summarize "the point of the story."45 The tarnished image of the Turkish State and its collaborators is more publicly memorable than what actually happened in the region. Gary Alan Fine put it plainly: "We remember our history not through the details of events but through the labels that characterize and summarize these events." "These labels," adds Fine, "have a life of their own., ${ }^{26}$ 


\section{Conclusion}

The real is relational.

- Pierre Bourdieu

At the outset of "Kurdish Opening" in the summer of 2009, I was on my way to Diyarbakır. Although the AKP government and then-Prime Minister Recep Tayyip Erdoğan were far from fulfilling their promises to reach a final settlement for the PKK's disarmament, local dynamics in the region were changing rapidly. Denied an interview earlier with the Istanbul representative of Mustazaf-Der - an association later closed due to its link with Hizbullah - I was not expecting a genuine conversation with Hizbullah or PKK activists in Diyarbakır. The calm political climate, however, enabled me not only to have in-depth conversations with all parties but also to get permission to record them in full. For those who observe Kurds at the grassroots, the Kurdish Opening was not simply about the AKP and the PKK guerilla forces; instead, it was a manifestation that hinted at much deeper transformation in local civil society step by step.

One of the most insightful approaches to understanding de-radicalization is political moderation theory. Studying revolutionary socialist parties in Europe, proponents of moderation theory believe that radicals gradually become moderate if they are allowed to operate within the legal and electoral system. ${ }^{1}$ In this perspective, three major factors are highlighted: the dynamics of electoral competition (carrots), the threat of state repression (sticks), and limited organizational resources - which make more investment in legal parties mean less investment in radical flanks. ${ }^{2}$ The moderation theory perspective, however, pays attention primarily to the state's relationship with one single political movement instead of a complex exchange among multiple players. The PKK's competition with pro-Islamic Kurds (such as Hizbullah and the Gülen movement) may be seen as secondary in importance, partly due to the perspective's exclusive focus on the electoral process.

1 See, Schumpeter 1942; Michels 1962; Przeworski 1985. Stathis Kalyvas later developed the perspective by analyzing right wing religious parties in Europe. See Kalyvas 1996; Kalyvas and van Kersbergen 2010. More recently, moderation theory was discussed regarding Islamist mobilizations in Egypt, Jordan and Yemen, and Turkey. For Egypt, see Wickham 2004; Hamid 2014. For Jordan and Yemen, see Schwedler 2006. For Turkey, see Tezcür 2010a.

2 Tezcür 2010a: 31. 
The scant attention paid to these local dynamics becomes more explicit when we consider the issue of state repression. Moderation theory suggests a model of carrot and stick, that is, less repressive measures toward official political party members and strong punishment for the radical challengers. Activists, however, may not be so lucky as to avoid the wrath of the state. As Nicole Watts notes on the Kurdish case, "Although some activists gain a certain amount of legal protection because of their status in office, neither they nor non-elected activists working within the system can necessarily expect the reduction in risk that their compatriots in more liberal systems enjoy."

Perhaps it is the opposite - "the personal and professional risks may sometimes go up."3 Watts adds that Turkey's political context poses significant challenges for moderation through pro-Kurdish parties. "In noncompetitive or semidemocratic regimes, the creation of movement-linked political parties and working within the formal political structures may signal a heightened cycle of contention and an expansion of the field of conflict." Analyzing the case of the Muslim Brotherhood in Egypt, Shadi Hamid comes to a similar conclusion. "Opposition moderation did not produce regime moderation," writes Hamid. "The confounding reality is that moderation is precisely what autocrats find so threatening."

In this book, I suggest going beyond the Turkish State vs. Kurds. Hence, as my argument goes, competition in civil society and the culture of rivalry provide institutional mechanisms in which various Kurdish actors would see their best interest in reputation building as legitimate non-violent actors instead of waging violence. Once these civic institutions are established and gradually developed over time, it is hard to go back.

One would be tempted to ask why the competing Kurdish groups do not outbid in violence instead. Why do they compete through non-violence? Why not compete to gain authenticity by furious attacks on the Turkish state? In fact, competition for violence is quite common as observed in the examples of Hamas and PLO rivalry and recently between Al-Qaeda and Daesh (ISIL). ${ }^{5}$

Such outbidding in violence, however, is mostly observed in the emergence period of revolutionary groups, exemplified in the cases of the PKK and Hamas when these groups needed to "prove" themselves. Moreover,

3 Watts 2010: 8.

4 Hamid 2014: 136.

5 For the "outbidding thesis" and its criticism, see Bloom 2004 and Brym and Araj 2008 respectively. 
the nature of contender groups in the local context matters. Why should the PKK promise violence to compete with the non-violent Gülen as waging violence could potentially destroy the PKK's credibility? Why would Hizbullah try outbidding in violence as the group is much weaker than the PKK, and moreover, it was non-violent activism that paved the way to the revival of Hizbullah from the ashes?

In fact, militant violence may lead to marginalization of the revolutionaries; stakes are too high and people tend to avoid costly high-risk activism. ${ }^{6}$ More importantly, militants would lose the fight over their public image, especially when the public receptiveness to "terrorism" charges is soaring. One recent example is the trajectory of Euskadi Ta Askatasuna (ETA), Basque Homeland and Freedom. In Spain, ETA has lost its public support considerably in the post $9 / 11$ era.

Aware of the problem of excessive violence, revolutionary movements develop a twofold strategy. On the one hand, they maintain strong guerilla forces or paramilitary groups to wage violence against the state authorities. On the other hand, they aim to build institutional bases in the civil society through non-violent social movement organizations. Revolutionaries often believe that maintaining a balance between waging violence and invoking non-violence would make them successful in their fight. ${ }^{8}$

I contend that increasing institutional activism in the civic sphere enables revolutionaries to build both legitimacy and institutional credibility. As they become active shapers of the civil society, they also become exposed to mainstream discourses. This gradual shift in discursive space is further reinforced by moral boundaries. In this respect, religious authority figures and trusted community leaders play important roles as moral entrepreneurs, bridging revolutionary culture and mainstream discourse. Once institutionalized, such discursive engagements can be powerful sources of legitimacy.

Then the question is whether such a double strategy introduces a genuine conflict transformation. Not necessarily. The civic organizations can be used to make strong patronage networks, as exemplified in the cases of Hamas and Lebanese Hizbullah. ${ }^{9}$ Such social service organizations not only invite a strong in-group identity but also provide an alternative government - a "state within the state" - in the making. Such patronage politics do not

6 On the free rider problem, see Olson 1965.

7 See, Alonso 2011.

8 Krause 2013: 259. See also, Gamson 1975.

9 See, Knudsen 2005; Karagiannis 2009. 
necessarily help in transforming conflict culture in civic spheres because each group would aim to give benefits to its own base, not being interested in encroaching on turf of the "other." In Egypt, for example, Islamists never become interested in winning the hearts and minds of popular voters at the expense of their ideological stance. Instead, as Hamid argues, they consciously avoid a strategy of engagement and thus, "learn to lose" at the ballot box for the sake of self-preservation. ${ }^{10}$

\section{Strategic Engagement and Conflict Transformation}

Strategic engagement appears to be the key to transforming ethnic conflicts. The PKK did not have to make an Islamic opening. Likewise, Hizbullah was not forced into publishing pro-Kurdish journals. It is true that the larger context encouraged the actors' decisions but these strategic moves were not necessary. In fact, ideology-based movements are often reluctant to pursue broader engagement strategies because of their deep concern for keeping the "purity" of their ideologies. In this regard, the PKK and Hizbullah took courageous steps. Political context shapes social action, but agents' choices at critical junctures are extremely significant in the final outcome.

Engagement strategies may invite a gradual shift in perceptions. As David Westby notes, "the strategic imperative may keep movement theorists and leaders abreast of social change and even ordain significant ideological transformations. ${ }^{{ }^{11}}$ Based on his case study in Northern Ireland, Lee Smithey explains how construction of a post-conflict culture requires a paradigm shift. In intractable ethno-political conflicts,

adversaries' identities can become defined such that they are mutually opposed to one another, indivisible, and non-negotiable. They become inseparable from the conflict that comes to be understood in zero-sum terms of "us" and "them." Using this calculus, any gain by one side amounts to an unacceptable loss by the other side. Each group feels as if its very existence is under threat, and each responds defensively, further modifying their own interpretive schemata to distinguish their opponents from themselves in even more stark terms, justifying more extreme action against opponents. ${ }^{12}$ 
Smithey contends that such intractable conflicts can take on "new forms" that have less violent outcomes - albeit not fully resolved. Similar to identity contests and competing narratives in the Kurdish case, the unionist activists' civic initiatives in a transforming civil society are based on "a strategy of public persuasion" in Northern Ireland. ${ }^{13}$

Winning hearts and minds in an ethnic constituency cannot be separable from electoral politics. Perhaps the most interesting aspect of the moderation theory is debate over strategic investment in electoral competition. Güneş Tezcür rightly points out the growing significance of such competition in Turkey. "A rigid state-society dichotomy overlooks the importance of electoral competition in shaping the strategies of Kurdish nationalists who have been deeply concerned with threats to their political hegemony from other Kurdish actors. ${ }^{114}$ Consider the following episode of contention.

In February 2011, prominent Kurdish poet Şivan Perwer met with Turkey's Deputy Prime Minister Bülent Arınç in Germany, declaring his support for the Turkish administration's "Kurdish Opening." Immediately afterwards, the PKK accused Perwer of being a jash, literally a "donkey's foal" in Kurdish. Jash is a highly political term that used to imply "collaborator" and "traitor." Perwer's prompt response was a YouTube video in which he explained his decades-long service to Kurds and Kurdistan. Speaking in Kurdish, Perwer condemned the PKK leaders for not even knowing the Kurdish language and concluded, "Be ashamed and apologize to Kurds. You do not have a right to declare anyone a traitor. If there are traitors, they are those who accuse others of being traitors." ${ }^{15}$

Şivan Perwer's experience was not exceptional. Some other pro-Kurdish leftists such as Ahmet Altan, Taner Akçam, and Roni Margulies faced similar

13 Ibid., pp. 34-35, 138. Since Smithey's primary focus is the cultural construction of post-conflict identities, he reasonably limits his analysis to the unionist/loyalist identities, not considering their main rival, i.e. nationalist/republican. Yet, as he suggests in his theoretical discussions (pp. 38-39), the strategy of public persuasion is an inter-subjective process in which both the unionist/loyalist and the nationalist/republican activists are involved. In fact, the emergence of nationalist/republican civic initiatives similar to their unionist/loyalist counterparts can be analyzed through a process of resemblance. Some unionist groups' formation of Irish language circles and the nationalist/republican activists' invitation of unionist/loyalist ex-combatants to their panels as speakers are recent examples of strategic engagements in a post-conflict culture. Quite similar to the Kurdish case, this competition driven exchange between these movements would have been unheard of a decade ago when a conflict culture was prevalent.

14 Tezcür 2009: 32.

15 After Perwer's public debate with the PKK, tensions escalated. PKK supporters attempted to sabotage Perwer's concert in the Netherlands. "Save your children and let them be educated (so that) they should not be like these clowns who assault their own people," Perwer angrily told his audience. See, Radikal 2011. 
allegations for their "treacherous" activism. ${ }^{16}$ Strikingly, however, the PKK did not respond harshly to Sezgin Tanrlkulu, another well-known figure among Kurds who joined the Republican People's Party (CHP), generally perceived as Ataturk's party defending Turkish nationalism.

The PKK's position was clear. Not Sezgin Tanrıkulu but Şivan Perwer, who flirted with the AKP government, should be publicly declared a traitor because it is not the secularists but the Islamists who are perceived as rivals for Kurdish votes. ${ }^{17}$ In her speech in Varto, Emine Ayna stated zealously, "No one who becomes a candidate of the AKP can say, 'I am a Kurd.' This is not acceptable because the AKP's policies deny the Kurds. Whoever becomes an AKP candidate is not a Kurd even if she says 'I am a Kurd.' "18

\section{Global Dynamics and Pro-Ethnic Strategies}

A constant play of "zoom-in" and "zoom-out" is necessary to grasp the pro-ethnic activist strategies. If we zoom out to see global dynamics, we may be able to understand how strategic engagement at local levels fits the larger picture. As Susan Olzak notes, "the spread of a world culture legitimating human rights for minorities and oppressed groups increases political opportunities for minorities, raises the likelihood of ethnic protest, and exacerbates ethnic tensions within states." ${ }^{19}$ The emerging discourse on human rights, of course, is strongly supported by the transnational organizations and the "core" nations in the world system. ${ }^{20}$ Thus, a nation state's increasing engagement with transnational political organizations (such as the EU, NATO, and the UN) would provide ethnic minorities within these states unprecedented resources and opportunity.

16 See, Botî 2010. Forty-one Kurdish intellectuals issued a joint declaration condemning threats against prominent Kurdish writers and artists by the Kurdistan Freedom Falcons, TAK. See, Sabah 2011. The PKK leaders, however, deny any connection with the TAK.

17 Non-specialized readers might wonder why I pick these particular cases. The cases of Şivan Perwer and Sezgin Tanrıkulu might be illuminating since they are both well-respected Kurds. I believe it is worthwhile to ask why declare Perwer a traitor and not label Tanrıkulu despite the fact that Perwer's relation to the AKP is quite different than Tanrıkulu's relation to the CHP: he only had a meeting with a high-ranking AKP official, whereas Tanrıkulu has joined the CHP as a party member. Yet, the AKP is seen as a major competitor in defining Kurdish identity, whereas the CHP is not perceived as a rival player in the field.

18 Quoted in Tezcür 2009: 11.

19 Olzak 2006: 9. Emphases in the original.

20 For the world-system perspective, see Wallerstein 1976. For transnational organizations and human rights regime, see Smith 1995; Smith and Johnston 2002. 
"As the states become more enmeshed in a world system of diplomats, economics, and financial and military obligations," contends Olzak, "state actions become more constrained by the density of ties." Thanks to these global integrative processes, ethnic groups "become less constrained by their own state authorities," and "(H)ighly integrated nation states cannot simply repress, jail, or torture the ethnic challengers without risking international condemnation. World-level sanctions are regularly employed to induce recalcitrant states to conform to international norms, as are military forces, advisers, and other external pressures." ${ }^{21}$

The world polity perspective is useful in explaining the significance of a larger global context for local politics. Moreover, the perspective offers substantial explanations of violence based on the world-systems approach. Olzak claims that dependent countries, which often suffer high rates of poverty, are significantly more prone to outbreaks of ethnic violence. On the other hand, dominant countries in the world-system experience non-violent ethnic contention.

Despite its considerable insights, the perspective is limited on two major fronts in studying ethnic violence. First, many cross-national studies of ethnic separatism suffer from a lack of attention to the internal structures of ethnic mobilizations, following the incumbent-challenger model. However, most of these movements are internally divided, and these divisions matter insofar as they shape state policies, independent from their place in the world system. In her cross-national research, for example, Kathleen Cunningham found that internally divided movements receive state concessions at a considerably higher rate than unitary ones, and the more divided the movement, the more likely it is to receive concessions. Cunningham's findings also suggest that concessions to unitary movements appear to work better at settling these disputes. Hence, "states use concessions not only as a tool to resolve disputes, but also as part of the bargaining process. ${ }^{.22}$

Second, the problems that have long plagued large-N analyses (such as endogeneity in causal analysis) make the world polity approach less attractive to those who would like to analyze meso-level factors with a holistic methodology. As Olzak acknowledges, "there are substantive reasons to believe that economic stability, political democracy, state violence, and group insurgency are all intertwined and involve simultaneous causation., ${ }^{23}$ The approach is especially silent about ethnic politics in the developing 
world, not fitting "core" vs. "dependent" categories. For example, what is the role of Turkey's EU membership process on the pace of the Kurdish insurgency? Should we expect more violence or less due to Turkey's higher interconnectedness with the transnational regime? What we learn is that globalization certainly encourages more protests overall, ${ }^{24}$ but resulting local outcomes could be violent, ${ }^{25}$ or non-violent, ${ }^{26}$ or selectively violent ${ }^{27}$ contentions in semi-democratic regimes. It might be useful to conceptualize globalization as a context for what Andreas Wimmer calls an "exogenous shift" ${ }^{\prime 28}$ that transforms the "arena" and "rules of the game." ${ }^{29}$ Yet, undertaking a strategy in this context still falls on the shoulders of ethnic activists.

\section{Toward a Multi-Institutional Politics Perspective}

This book draws on unique insights from a multi-institutional politics perspective in studying conflict transformation and ethnic mobilization. First, unlike structuralist accounts that assume power is primarily vested in the state, we need to understand power as "dispersed." ${ }^{\circ}$ The structuralist view is unwarranted especially in a rapidly globalized world: since the 1960 , only about one-third of all self-determination movements around the globe can be considered as unitary actors in their interactions with the state. ${ }^{31}$ The Kurdish case is no exception.

The exclusive attention to the state is also delimiting because "society is composed of multiple and often contradictory institutions," as attested to in the recent waves of institutional, feminist, and cultural theories. ${ }^{32}$ Similar to neo-Marxist scholars who debate about the nature of the state, pro-ethnic activists may differ in their conceptualizations of how state

\footnotetext{
24 Goldstone 2004: 333.

25 Fearon and Laitin 2003: 75 .

26 See, Nepstad 2011.

27 Goodwin 2006: 2027.

28 Wimmer 2008: 1005 .

29 Jasper 2004: 5. For an excellent conceptual discussion, see Cunningham 2012.

30 For the conception of power as "dispersed," see Foucault 1977, 1980. For the neo-liberal transformations and social movements, see Voss and Williams 2012.

31 The data comes from Kathleen G. Cunningham's sample of self-determination groups. Only $8 \%$ of the self-determination groups in the sample are continuously represented by only one organization. Cunningham defines self-determination group factions as "any organizations that represent the SD group and make demands related to self-governance, such as the Kurdish Worker's Party in Turkey." See, Cunningham 2011: 275.

32 Armstrong and Bernstein 2008: 82. See, for example, Sewell 1992 and Fligstein 1997.
} 
power operates. Activists are lay theorists, unwittingly narrating ideas of power and dominance in everyday life. These divergent understandings of power and domination, of course, would shape the targets of mobilization and the means by which to challenge structures. Hence, an a priori assumption that considers the state as the target is misguided.

Jack Goldstone highlights how social movement activists are indeed embedded in "external relational fields." These fields include

(1) other movements and countermovements that may compete for attention and resources, or provide reinforcement and alliances, or engage in direct competition or conflict with the movement; (2) political and economic institutions (and their history) that provide the framework in which movements recruit, act, and seek responses; (3) various levels of state authorities and political actors (including political parties and civil and military officials) whose responses to the movement and its actions affect its developments and outcomes; (4) various elites - economic, political, religious, media - whose interests, capacities, and actions affect movement development and its outcomes; (5) various publics whose interests, capacities, and actions affect movement development and its outcomes; (6) symbolic and value orientations available in society that condition the reception and response to movement claims and actions; and (7) critical events - such as wars, economic crises, or incidents of violence or outcomes of specific episodes of confrontation.

According to Goldstone, "it is the relations among these elements of the external field - both relations among them and of them to movement claims and actions - that appear to shape movement dynamics." Thus, Goldstone rightly concludes, we need to regard social movements "as elements in a complex field of players in politics and society that are seeking advantages by using a variety of tactics. ${ }^{\prime 3}$

Second, culture is regarded as "constitutive" of the structure instead of having a derivative, secondary, and trivial role. ${ }^{34}$ Pro-Kurdish mobilizations cannot be grasped without taking emotional dimensions seriously. ${ }^{35}$ Compe-

Goldstone 2004: $35^{8}$.

34 Armstrong and Bernstein are not the first scholars making this argument. A remarkable body of literature emerged after the "cultural turn" in social movement studies, calling for taking culture and emotions seriously. See, for example, Jasper 1997; Goodwin and Jasper 1999; Polletta 1997, 1999, 2006; Goodwin, Jasper, and Polletta 2000, 2001.

35 This emphasis has been pervasive due to the pejorative legacy of emotions in classical models of social movement theories. Even the definitions of social movements were defined 
tition among ethno-political and Islamic activists to build moral authority, legitimacy, and prestige has become a constitutive element of everyday politics in the past decade. "Feeling the game" in town, ${ }^{36}$ what Charles Tilly calls "the blame game, ${ }^{\prime \prime 37}$ these rival activists have developed certain norms and repertoires regarding how to perform their reputation work. The "practical" senses "of a particular social game" ${ }^{{ }^{3} 8}$ have little instrumentalist logic to them because contentious players "may be ready to die for those ends, independently of all considerations of specific, lucrative profits, career profits, or other forms of profits." ${ }^{39}$

Moreover, we cannot grasp the nature of political institutions and their potential effects without a proper understanding of the culture and emotions of ethnic politics. If there is a causal impact of institutions upon collective action forms (such as radicalization and moderation), it heavily depends upon "their emotional dimensions," often "left untheorized." ${ }^{\circ 0}$ These emotional dimensions, however, should not be regarded as attributes of individuals or their actions "within the sphere of subjectivity alone"; instead, we need to consider "emotions in terms of relationships, not substances. ${ }^{31}$ Transpersonal phenomena (such as ethnic solidarity, trust, reputation building, and so forth) and social movement rivalry analyzed in this book call for a relational approach in understanding collective emotional processes.

As Mustafa Emirbayer and Chad Goldberg rightly suggest, "emotional sociology" is needed, not "sociology of emotions" - in a similar fashion to what Jeffrey Alexander and his colleagues have done regarding the study of culture. There is "something to be explained" when we utter a "sociology of culture" or a "sociology of emotions" as if they could be separated from everyday social reality. "If we allow this separate thing to be called 'sociology,' then we define our field as the study of substructures, bases, morphologies, 'real' things, and 'hard' variables, and we reduce [collective psychology] to superstructures ... sentiments, 'unreal' [passions] and 'soft' dependent variables." ${ }^{\prime 2}$ "Emotions," agrees Jim Jasper in his call to social

in a rational-choice language. For example, Doug McAdam 1982: 20 defines social movements as "rational attempts by excluded groups to mobilize sufficient political leverage to advance collective interests through noninstitutionalized means." For problems in studying emotions in social movement scholarship, see Emirbayer and Goldberg 2005; Jasper 2011a.

36 For the metaphor, see Bourdieu 1998: 77-83.

37 Tilly 2010a: 382 .

38 Lamaison and Bourdieu 1986: 112.

39 Bourdieu 1998: 83.

40 Emirbayer and Goldberg 2005: 480.

41 Emirbayer and Goldberg 2005: 471, 486.

42 Alexander 1996: 3 quoted in Emirbayer and Goldberg 2005: 494. 
movement scholars, "are part of a flow of action and interaction, not simply the prior motivations to engage or the outcomes that follow."43

Third, a multi-institutional politics perspective favors a relational sociology in understanding the role of agency. ${ }^{44}$ The moderation of radicals and conflict transformation in Turkey cannot be solely explained by either political structures or individual preferences. As a prominent thinker in relational sociology, Pierre Bourdieu argues that social action should be conceptualized in its own practical complexity, as it is based on "acquired dispositions" where "an action can and should be interpreted as oriented toward one objective or another without anyone being able to claim that objective was a conscious design. ${ }^{45}$ As an example of acquired dispositions, Bourdieu frequently employs the metaphor of playing games. Players sooner or later internalize the rules of the games without strategic calculations. They increasingly "feel the game" as they play it..$^{46}$

Recent applications of Bourdieu in ethnicity literature offer insights that are congruent with the multi-institutional politics perspective. The work of prominent scholars such as Roger Brubaker and Andreas Wimmer are especially useful in explaining "boundary-making" strategies in ethnic politics. According to the "ethnic boundary-making" approach, collective ethnic action is "not simply a function of some presocial forms of rationality or interest, any more than it is a mere performance of a free-floating script or narrative." Though interests might be "positional and symbolic," and therefore, "irreducibly social" and relational, there is "considerable room for creativity and improvisation."47

Philip Gorski and Gülay Türkmen-Dervişoğlu succinctly note the potential contribution of such novel perspectives regarding the study of

43 Jasper 2011a: 297 .

44 For the role of agency in a "relational sociology" framework, see Emirbayer and Goodwin 1994; Emirbayer 1997; Emirbayer and Mische 1998; Mische 2011.

45 Bourdieu 1998: 97-98. Bourdieu's oeuvre was strongly influenced by the social context of the French academy, wherein two schools of thought were in radical negation of one another; that is, Sartre's voluntarism and Levi-Strauss' structuralism. For Bourdieu, Sartre's strong emphasis on "the creativity, freedom, and undetermined power of choice of the individual subject" and Levi-Strauss' stress on the "causal power of structures ... operating independently of the consciousness of the agents" are both obstacles to the construction of a satisfactory social theory. See, Brubaker 1985: 746. Avoiding pitfalls of subjectivism or objectivism, Bourdieu finds a middle ground where the social reality is seen as "relational." In his words, "the real is the relational: what exists in the social world are relations, not interactions between agents or inter-subjective ties between individuals, but objective relations which exist 'independently of individual consciousness and will,' as Marx said." Quoted in Wacquant 1989: 39.

46 Bourdieu 1998: 77, 98. 
ethnic mobilization and conflict resolution: "(T)he crucial mechanisms of ethnic and nationalist mobilization and conflict are not to be found in the autonomous structures of culture, nor in the self-interests of individual actors, but in between the macro and micro levels. ${ }^{148}$ Thus, in this book, I pay ample attention to the dynamics of exchange among rival social movement activists and their multivocal - sometimes ambiguous and often contradictory - interpretations of a changing political context.

\section{A Kurdish Spring on the Horizon?}

In the next decade, global and local dynamics suggest two major developments. First, Kurdish self-determination will be expressed ever strong in Turkey. Despite close relations with the PKK, the Syrian Kurdish cantons at Turkey's borders are now increasingly perceived as the legitimate local governments by the international community. As discussed in chapter 3, Öcalan's Democratic Republic thesis has evolved through the relational dynamics, started with a secularist paradigm to reach out to the old Turkish elite against the AKP. In a similar vein, the PKK's abstract conceptualization of "self-determination" takes a tangible face in most secularist forms to get Western elite support in the wake of a radical Islamist threat in the Middle East. The claim of democratic local governance in Syria is also tied to the Turkish context where Kurdish ethno-nationalists forcefully demand broader rights for self-rule in the form of European models of federalism.

Thus, it is highly possible to see a de facto autonomy of Kurds in Syria, which would inevitably lead to Southeastern Turkey becoming more independent in its governance at local levels. European models of federalism will be discussed in a most heated fashion, but the holding of a plebiscite such as Scotland's seems unlikely. Such an official change in Turkey's policy may only be seen after a formally independent Kurdistan in northern Iraq.

The second major development on the horizon is the advent of a postÖcalan era in Kurdish politics. Successful election campaigns of the proKurdish party against the authoritarian Erdoğan regime have boosted the prestige of Kurdish politicians, providing them unprecedented reach and influence. Young leaders such as Selahattin Demirtaş and Sırrı Süreyya Önder have gained prominence because they are increasingly perceived as reasonable actors for a permanent peace. Their ever inclusive language draws votes from both pro-Islamic Kurds and pro-secular Turks. For the 
first time, PKK commanders in the Qandil mountains face a challenge of multivocal pro-Kurdish organizations beyond Abdullah Öcalan. Thus, the traditional players are replaced with a variety of actors under the forces of social competition.

Despite the escalation of violence in late 2015 and ensuing PKK hegemony among Kurds, Turkey's Kurdish conflict nowadays is by no means comparable to the 199os, the "dirty war" years. This book is a humble attempt to explain "why" and "how" such transformation occurred at the grassroots. 



\section{List of Abbreviations}

$\begin{array}{ll}\text { AKP } & \text { Adalet ve Kalkınma Partisi (Justice and Development Party) } \\ \text { BDP } & \text { Barış ve Demokrasi Partisi (Peace and Democracy Party) } \\ \text { CHP } & \text { Cumhuriyet Halk Partisi (Republican People's Party) } \\ \text { Daesh (ISIL) } & \text { al-Dawla al-Islamiyya fil Iraq wa'al Sham (Islamic State of Iraq and the } \\ & \text { Levant) } \\ \text { DBP } & \text { Demokratik Bölgeler Partisi (Democratic Region's Party) } \\ \text { DİAYDER } & \text { Din Adamları Yardımlaşma ve Dayanışma Derneği (Religious Leaders' } \\ & \text { Assistance and Solidarity Association) } \\ \text { DTP } & \text { Demokratik Toplum Partisi (Democratic Society Party) } \\ \text { DEHAP } & \text { Demokratik Halk Partisi (Democratic People's Party) } \\ \text { ETA } & \text { Euskadi Ta Askatasuna (Basque Homeland and Freedom) } \\ \text { FP } & \text { Fazilet Partisi (Virtue Party) } \\ \text { HADEP } & \text { Halkın Demokrasi Partisi (People's Democracy Party) } \\ \text { HEP } & \text { Halkın Emek Partisi (People's Labor Party) } \\ \text { HÜDA-PAR } & \text { Hür Dava Partisi (Free Cause Party) } \\ \text { JITEM } & \text { Jandarma İstihbarat ve Terörle Mücadele (Gendarmerie Intelligence and } \\ & \text { Fight against Terrorism) } \\ \text { KADEK } & \text { Kurdish Freedom and Democracy Congress } \\ \text { KCK } & \text { Koma Civaken Kurdistan (Union of Communities in Kurdistan) } \\ \text { KRG } & \text { Kurdistan Regional Government } \\ \text { MSP } & \text { Milli Selamet Partisi (National Salvation Party) } \\ \text { PKK } & \text { Partiya Karkeren Kurdistan (Kurdistan Workers' Party) } \\ \text { PWD } & \text { Partiya Welatparêzên Demokrat (Democratic Patriots' Party) } \\ \text { RP } & \text { Refah Partisi (Welfare Party) } \\ \text { SP } & \text { Saadet Partisi (Felicity Party) } \\ \text { TAK } & \text { Teyrênbazê Azadiye Kurdistan (Kurdistan Freedom Falcons) } \\ \text { TZP } & \text { Kurdi, Tevgera Ziman û Perverdehiya Kurdî (Movement for Kurdish } \\ \text { YPG } & \text { Language and Education) } \\ \text { Yekîneyên Parastina Gel (People's Protection Units) } \\ \end{array}$





\section{References}

Abbott, Andrew. 2001. Time Matters: On Theory and Method. Chicago and London: University of Chicago Press.

Abu-Rabi, Ibrahim (ed.). 2003. Islam at the Crossroads: On the Life and Thought of Bediuzzaman Said Nursi. Albany: State University of New York Press.

- 2008. Spiritual Dimensions of Bediuzzaman Said Nursi's Risale-i-Nur. Albany: State University of New York Press.

Agai, Bekim. 2002. "The Gülen Movement's Islamic Ethic of Education.” Critique: Critical Middle Eastern Studies 11: 27-47.

— 2005. "Discursive and Organizational Strategies of the Gülen Movement." Presented at the International Conference, Islam in the Contemporary World: The Fethullah Gülen Movement in Thought and Practice, Rice University, Houston, TX.

Agnew, John. 1989. "Beyond Reason: Spatial and Temporal Sources of Ethnic Conflicts." Pp. 41-52. In Intractable Conflicts and their Transformation edited by Louis Kriesberg, Terrell A. Northrup, and Stuart Thorson. Syracuse: Syracuse University Press.

Akbulut-Kuru, Zeynep and Ahmet T. Kuru. 2008. "Apolitical Interpretation of Islam: Said Nursi's Faith-based Activism in Comparison with Political Islamism and Sufism." Islam and Christian-Muslim Relations 19: 99-111.

Akçura, Belma. 2009. Devletin Kürt Filmi. İstanbul: New Age Yayınları.

Akturk, Sener. 2012. Regimes of Ethnicity and Nationhood in Germany, Russia, and Turkey. Cambridge: Cambridge University Press.

Akyol, Mustafa. 2006. Kürt Sorununu Yeniden Düşünmek. Istanbul: Doğan Kitap.

— 2013. "Is Gülen Movement against Peace with PKK?" Al-Monitor, May 22, 2013, http://www. al-monitor.com/pulse/originals/2013/05/Gülen-movement-peace-process-pkk.html

Alderman, Derek. 2002. "Street Names as Memorial Arenas: The Reputational Politics of Commemorating Martin Luther King Jr. in a Georgia County." Historical Geography 30: 99-120.

Alexander, Jeffrey. 1996. "Cultural Sociology or Sociology of Culture?” Newsletter of the Sociology of Culture Section of the American Sociological Association 10: 3-5.

Almeida, Paul D. 2008. Waves of Protest: Popular Struggle in El Salvador, 1925-2005. Minneapolis: University of Minnesota Press.

Al-Sayyid, Mustapha. 1993. “A Civil Society in Egypt?” Middle East Journal 47: 228-42.

Alonso, Rogelio. 2011. "Why do Terrorists Stop? Analyzing Why ETA Members Abandon Or Continue with Terrorism." Studies in Conflict \& Terrorism 34: 696-716.

Andrews, Peter Alford. 2002. Ethnic Groups in the Republic of Turkey. Wiesbaden: Dr. Ludwig Reichert Verlag.

Aras, Bulent and Gökhan Bacık. 2002. "The Mystery of Turkish Hizballah." Middle East Policy IX: 147-6o.

Armstrong, Elizabeth and Mary Bernstein. 2008. "Culture, Power, and Institutions: A MultiInstitutional Politics Approach to Social Movements." Sociological Theory 26: 74-99.

Atak, Mehmet İ. 2011. "Pensilvanya Kraliyet Güçleri Müslüman Mahallesine Dadanmıştır.” Doğru Haber February 11.

Auyero, Javier. 1999. “'From the Client's Point(s) of View: How Poor People Perceive and Evaluate Political Clientelism.” Theory and Society 28: 297-334

—, Pablo Lapegna, and Fernanda P. Poma. 2009. "Patronage Politics and Contentious Collective Action: A Recursive Relationship." Latin American Politics and Society 51:1-31. 
Ayata, Bilgin. 2011. "Kurdish Transnational Politics and Turkey's Changing Kurdish Policy: The Journey of Kurdish Broadcasting from Europe to Turkey." Journal of Contemporary European Studies 19: 523-33.

Aytar, Volkan. 2006. Recasting a Vital Balance in Difficult Times: How to Increase the Visibility in Turkey of the new European Values and Processes of Security and Human Rights. Istanbul: TESEV.

Badıllı, Abdulkadir. 1998. Bediuzzaman Said-i Nursi, Mufassal Tarihçe-i Hayati. İstanbul: Timaş. Bagasi, Isa. 2004. Kendi Dilinden Hizbullah ve Mücadele Tarihinden Önemli Kesitler. Unknown Publisher.

BAĞLAR. 2010. Diyarbakır Bağlar Belediyesi 2010 Yılı Faaliyet Raporu. İstanbul: Gün.

Bakhtin, Michael. 1981. The Dialogic Imagination: Four Essays. Austin, TX: University of Texas Press.

— 1986. Speech Genres, and Other Late Essays. Austin, TX: University of Texas Press.

Bal, İhsan. 20o6. "Türkiye'nin Terörle Mücadele Tecrübesi: Hizbullah Terör Örgütü Örneği." Pp. 17-39 In Terörizm:Terör, Terörizmve Küresel Terörle Mücadelede Ulusalve Bölgesel Deneyimler, edited by İhsan Bal, Ankara: USAK.

Balcı, Ali and Ibrahim Efe. 2014. The 2014 Local Elections: Reflections on the Kurdish Question. Istanbul: SETA.

Balc1, Fatih. 2008. Politicization of Kurdish Question through Human Rights Discourse in Turkey. Ph.D. Dissertation. University of Utah.

Barkey, Henri J. and Graham E. Fuller. 1998. Turkey's Kurdish Question. Lanham, MD: Rowman \& Littlefield.

Bar-tal, Daniel and Gavriel Salomon. 2006. "Israeli-Jewish Narratives of the Israeli-Palestinian Conflict: Evolution, Contents, Functions, and Consequences." Pp. 19-46 in Israeliand Palestinian Narratives of Conflict: History's Double Helix, edited by Robert Rotberg, Bloomington: Indiana University Press.

Bender, Cemşid. 1991. Kürt Tarihi ve Uygarlığı. İstanbul: Kaynak.

Benford, Robert D. 1993. "Frame Disputes within the Nuclear Disarmament Movement." Social Forces 71: 677-701.

— 1997. “An Insider's Critique of the Social Movement Framing Perspective." Sociological Inquiry 67: 409-30.

— and Louis A. Zurcher. 1990. "Instrumental and Symbolic Competition among Social Movement Organizations." Pp. 125-39 in Peace Action in the Eighties, edited by Sam Marullo and John Lofland. New Brunswick, NJ: Rutgers University Press.

— and David A. Snow. 2000. "Framing Processes and Social Movements: An Overview and Assessment." Annual Review of Sociology 26: 611-39.

Berkowitz, Lenka and Liza M. Mügge. 2014. "Transnational Diaspora Lobbying: Europeanization and the Kurdish Question." Journal of Intercultural Studies 35: 74-90.

Bernstein, Mary. 1997. "Celebration and Suppression: The Strategic Uses of Identity by the Lesbian and Gay Movement." American Journal of Sociology 103: 531-65.

— 2005. "Identity Politics." Annual Review of Sociology 31: 47-74.

— 2008. "The Analytic Dimensions of Identity." Pp. 277-301 in Identity Work, edited by Jo Reger, Rachel Einwohner, and Daniel Myers. Minneapolis: University of Minnesota Press.

— 2013. "Power, Politics, and Social Movements: A Multi-Institutional Politics Approach." Politics, Groups, and Identities 1: 87-93.

Beşikçi, İsmail. 1977. Türk-Tarih Tezi, Güneş-Dil Teorisive Kürt sorunu. Ankara: Komal. 
Birch, Nicholas. 2010. "Are PKK and Gülen Movement Burying Hatchet." EURASIANET.org December 16. Available at http://www.eurasianet.org/node/62585 Accessed April 15, 2012.

Bloom, Mia. 2004. "Palestinian Suicide Bombing: Public Support, Market Share, and Outbidding." Political Science Quarterly 119: 61-88.

Botî, Berzan. 2010. “Aydınlar Neden Kutsal Ailenin Hedefinde.” Nasname, http://www.nasname. com/Yazarlar/bboti/789o.html, Accessed November 17, 2010.

Boudreau, Thomas and Brian Polkinghorn. 2008. "Reversing the Destructive Discourses of Dehumanization: A Model for Reframing Narratives in Protracted Social Conflict through Identity Affirmation." Research in Social Movements, Conflicts, and Change 29: 175-205.

Boudreau, Vincent. 1996. "Northern Theory, Southern Protest: Opportunity Structure Analysis in Cross-National Perspective." Mobilization 1: 175-89.

Bourdieu, Pierre. 1984. Distinction: A Social Critique of the Judgement of Taste. (Trans. by Richard Nice) Cambridge: Harvard University Press.

- 1990. The Logic of Practice. Stanford, CA: Stanford University Press.

- 1993. Sociology in Question. London: Sage.

- 1998. Practical Reason: On the Theory of Action. Stanford, CA: Stanford University Press.

— and Loic Wacquant. 1992. An Invitation to Reflexive Sociology. London: University of Chicago Press.

Bozkurt, Abdullah. 2014. “Erdogan Hampers Girls' Education.” Today's Zaman, April 18.

Brubaker, Rogers. 1985. "Rethinking Classical Theory: The Sociological Vision of Pierre Bourdieu." Theory and Society 14: 745-75.

- 1992. Citizenship and Nationhood in France and Germany. Cambridge, MA: Harvard University Press.

— 2004. Ethnicity without Groups. Cambridge, MA: Harvard University Press.

— 2012. "Religion and Nationalism: Four Approaches." Nations and Nationalism 18: 2-20.

— and Frederick Cooper. 2000. "Beyond 'Identity'." Theory and Society 29: 1-47.

Brym, Robert and Bader Araj. 2008. "Palestinian Suicide Bombing Revisited: A Critique of the Outbidding Thesis." Political Science Quarterly 123: 485-500.

Brynen, Rex. 2008. "Aid as Carrot, Aid as Stick: The Politics of Aid Conditionality in the Palestinian Territories." Conciliation Resources Available at http://www.c-r.org/accord-article/aidcarrot-aid-stick-politics-aid-conditionality-palestinian-territories Accessed April 14, 2012.

Casier, Marlies. 2010. "Turkey's Kurds and the Quest for Recognition: Transnational Politics and the EU-Turkey Accession Negotiations." Ethnicities 10: 3-25.

Castells, Manuel. 1997. The Power of Identity. Oxford: Blackwell.

Cemal, Hasan. 2004. Kürtler. İstanbul: Doğan Kitap.

— 2009. "Karayılan: Fethullahçılar Geleceğe Dönük Büyük bir Risk," Milliyet, May 8.

Clark, Janine. 2004. Islam, Charity, and Activism: Middle-Class Networks and Social Welfare in Egypt, Jordan, and Yemen. Bloomington, IN: Indiana University Press.

Clemens, Elisabeth. 1996. "Organizational Form as Frame: Collective Identity and Political Strategy in the American Labor Movement." Pp. 205-26. In Comparative Perspectives on Social Movements: Political Opportunities, Mobilizing Structures, and Cultural Framings, edited by Doug McAdam, John McCarthy, and Mayer Zald. New York: Cambridge University Press.

- 2007. "Toward a Historicized Sociology: Theorizing Events, Processes, and Emergence." Annual Review of Sociology 33: 527-49.

Cobb, Sara. 2013. Speaking of Violence: The Politics and Poetics of Narrative in Conflict Resolution. New York: Oxford University Press. 
Coşkun, Handan. 2006. "Dikasum Deneyimi: Göç ile Yok Olan Hayatlar." International Symposium organized by TESEV, Türkiye'de ve Dünyada Yerinden Edilme: Uluslararası İlkeler, Deneyimler ve Çözüm Önerileri (Istanbul, Turkey), December 4-5.

Crooke, Alastair and Vanessa Shields. 2005. "The Road Ahead: Perspectives on Disarming Hamas." Conciliation Resources http://www.c-r.org/our-work/accord/engaging-groups/ road-ahead.php Accessed July 9, 2011.

Crossley, Nick. 2003. "From Reproduction to Transformation: Social Movement Fields and the Radical Habitus." Theory, Culture \& Society 20: 43-68.

Cunningham, David. 2012. "Mobilizing Ethnic Competition." Theory and Society 41: 505-25.

Cunningham, Kathleen G. 2011. "Divide and Conquer or Divide and Concede: How Do States Respond to Internally Divided Separatists?” American Political Science Review 105: 275-97.

Curtis, Russell L. and Louis A. Zurcher. 1973. "Stable Resources of Protest Movements: The Multi-Organizational Field." Social Forces 52: 53-61.

— 1974. "Social Movements: An Analytical Exploration of Organizational Forms." Social Problems 21: 35 6-70.

Çağlayan, Ercan. 2014. Cumhuriyet'in Diyarbakır'da Kimlik Inşası. İstanbul: İletişim.

Çağlayan, Handan. 2007. Analar, Yoldaşlar, Tanrıçalar: Kürt Hareketinde Kadın Kimliğinin Oluşumu. İstanbul: İletişim.

Çakır, Ruşen. 2001. Derin Hizbullah. İstanbul: Metis.

- 2007. The Re-emergence of Hizballah in Turkey. Washington, DC: Washington Institute for Near East Policy.

— 2013. “Gülen Cemaati 19 Yıldır Irak Kürdistan'ına Hizmet Götürüyor," Vatan Jan 23.

Çevik, Yusuf. 2012. "The Reflections of Kurdish Islamism and Everchanging Discourse of Kurdish Nationalists toward Islam in Turkey." Turkish Journal of Politics 3: 87-102.

Çiçek, Nevzat. 2008. Puşive Sarık: İslam Kürt Sorununu Çözer Mi? İstanbul: Hayykitap.

Dağı, İhsan. 2005. "Transformation of Islamic Political Identity in Turkey: Rethinking the West and Westernization." Turkish Studies 6: 21-37.

Davis, Joseph E. (ed.). 2002. Stories of Change: Narrative and Social Movements. Albany, NY: SUNY Press.

Day, Will. 2008. "The Politics of Poverty in Turkey's Southeast." Middle East Report 247: 24-26.

De Bellaigue, Christopher. 2007. "The Uncontainable Kurds." The New York Review of Books 54: 34-39.

Della Porta, Donatella. 1995. Social Movements, Political Violence, and the State: A Comparative Analysis of Italy and Germany. Cambridge: Cambridge University Press.

— and Dieter Rucht. 1995. "Left-Libertarian Movements in Context: A Comparison of Italy and West Germany, 1965-199o." Pp. 229-72 in The Politics of Social Protest: Comparative Perspectives on States and Social Movements, edited by Bert Klandermans and Craig Jenkins. Minneapolis, MN: University of Minnesota Press.

Demir, Eyyüp. 2005. Yasal Kürtler. İstanbul: Tevn Yayınevi.

Demir, Mustafa. 2012. "Evolution in Discourse: Turkey and the KRG," Turkish Review 2: 91-96.

Demircan, Cemil. 20o9. “A. Öcalan'ı Tanrılaştırmak.” Nasname: Özgür Bireyler Topluluğu Website, January 17. http://www.nasname.com/Yazarlar/cdemircan/4686.html Accessed April 20, 2010.

Diani, Mario. 2003. "The Terrestrial Emporium of Contentious Knowledge." Mobilization 8: 109-112.

Dohrn, Kristina. 2013. “Translocal Ethics: Hizmet Teachers and the Formation of Gülen-inspired Schools in Urban Tanzania." Sociology of Islam 1: 233-56. 
DuBois, Ellen. 1978. Feminism and Suffrage. Ithaca: Cornell University Press.

Ducharme, Lori J. and Gary Alan Fine. 1995. "The Construction of Nonpersonhood and Demonization: Commemorating the Traitorous Reputation of Benedict Arnold." Social Forces 73: 1309-31.

Dündar, Can. 2009. "Kart-Kurt, Alt-Üst Oldu." Milliyet April 16.

Ebaugh, Helen R. 2010. The Gülen Movement: A Sociological Analysis of a Civic Movement Rooted in Moderate Islam. London and New York: Springer.

Eccarius-Kelly, Vera. 2011. The Militant Kurds: A Dual Strategy for Freedom. Santa Barbara, CA: Praeger.

Elphinston, William G. 1946. "The Kurdish Question." International Affairs 22: 91-103.

Emirbayer, Mustafa. 1997. "Manifesto for a Relational Sociology." American Journal of Sociology 103: $281-317$.

— and Jeff Goodwin. 1994. "Network Analysis, Culture, and the Problem of Agency." American Journal of Sociology 99: 1411-53.

— and Ann Mische. 1998. "What is Agency?" American Journal of Sociology 103: 962-1023.

— and Chad A. Goldberg. 2005. "Pragmatism, Bourdieu, and Collective Emotions in Contentious Politics." Theory and Society 34: 469-518.

Ergil, Doğu. 2010. "PKK-Gülen.” Today's Zaman Dec 15.

Ersanlı, Büşra. 2003. İktidarve Tarih: Türkiye'de Resmi Tarih Tezinin Oluşumu, 1929-1937. İstanbul: İletişim.

Ewick, Patricia and Susan Silbey. 2003. "Narrating Social Structure: Stories of Resistance to Legal Authority." American Journal of Sociology 108: 1328-72.

Eyerman, Ron. 2006. "Performing Opposition or, How Social Movements Move." Pp. 193-218 in Social Performance: Symbolic Action, Cultural Pragmatics, and Ritual. Edited by Jeffrey C. Alexander, Bernhard Giesen, and Jason L. Mast. Cambridge, MA: Cambridge University Press.

Faraç, Mehmet. 2009. "Ya Allah Bismillah ... Abdullah!..” Cumhuriyet, September 15.

Fearon, James D. and David D. Laitin. 2003. "Ethnicity, Insurgency, and Civil War." American Political Science Review 97: 75-90.

Fetner, Tina. 2008. How the Religious Right Shaped Lesbian and Gay Activism. Minneapolis, MN: University of Minnesota Press.

Fine, Gary A. 2001. Difficult Reputations: Collective Memories of the Evil, Inept, and Controversial. Chicago: University of Chicago Press.

— 20o6. "Notorious Support: The America First Committee and the Personalization of Policy." Mobilization 11: 405-26.

Flanigan, Shawn T. and Mounah Abdel-Samad. 2009. "Hezbollah's Social Jihad: Nonprofits as Resistance Organizations." Middle East Policy XVI: 122-37.

Fligstein, Neil. 1997. "Social Skill and Institutional Theory." American Behavioral Scientist 40: 397-505.

— and Doug McAdam. 2011. "Toward a General Theory of Strategic Action Fields." Sociological Theory 29: 1-26.

— 2012. A Theory of Fields. Oxford: Oxford University Press.

Foucault, Michel. 1977. Discipline and Punish: The Birth of the Prison. New York: Vintage.

— 1980. Power/Knowledge: Selected Interviews and Other Writings 1972-1977. New York: Vintage.

Fox, Jonathan. 2002. Ethnoreligious Conflict in the Late Twentieth Century. Oxford: Lexington Books. 
Galtung, Johan. 1995. "Conflict Resolution as Conflict Transformation: The First Law of Thermodynamics Revisited.” Pp. 51-64. In Conflict Transformation edited by Kumar Rupesinghe. New York: St. Martin's Press.

Gamson, William A. 1975. The Strategy of Social Protest. Homewood, IL: Dorsey Press.

Gellner, Ernest. 1983. Nations and Nationalism. Ithaca: Cornell University Press.

— 1997. "The Turkish Option in Comparative Perspective." Pp. 233-44. In Rethinking Modernity and National Identity in Turkey edited by Sibel Bozdoğan and Reşat Kasaba. Seattle:University of Washington Press.

— and John Waterbury (eds.). 1977. Patrons and Clients in Mediterranean Societies. London: Duckworth.

Ghaziani, Amin. 2008. The Dividends of Dissent: How Conflict and Culture Work in Lesbian and Gay Marches on Washington. Chicago: University of Chicago Press.

— 2011. "Post-Gay Collective Identity Construction." Social Problems 58: 99-125.

Girardi, Giulio. 1989. Faith and Revolution in Nicaragua. Maryknoll, NY: Orbis Books.

Goldstone, Jack. 2004. "More Social Movements or Fewer? Beyond Political Opportunity Structures to Relational Fields." Theory and Society 33: 333-65.

- 2010. "From Structure to Agency to Process: The Evolution of Charles Tilly's Theories of Social Action as Reflected in His Contentious Politics." American Sociologist 41: 358-67.

— and Bert Useem. 2012. "Putting Values and Institutions Back into the Theory of Strategic Action Fields." Sociological Theory 30: 37-47.

Goodwin, Jeff. 1997. “The Libidinal Constitution of a High-Risk Social Movement: Affectual Ties and Solidarity in the Huk Rebellion, 1946 to 1954." American Sociological Review 62: 53-69.

— 2006. "A Theory of Categorical Terrorism." Social Forces 84: 2027-46.

Goodwin, Jeff and James M. Jasper. 1999. "Caught in a Winding, Snarling Vine: The Structural Bias of Political Process Theory.” Sociological Forum 14: 27-54.

- (eds.). 2011. Contention in Context: Political Opportunities and the Emergence of Protest. Stanford, CA: Stanford University Press.

Goodwin, Jeff and Theda Skocpol. 1989. "Explaining Revolutions in the Contemporary Third World." Politics and Society 17: 489-509.

Goodwin, Jeff, James M. Jasper, and Francesca Polletta. 200o. "The Return of the Repressed: The Fall and Rise of Emotions in Social Movement Theory." Mobilization 5: 65-83.

— (eds.). 2001. Passionate Politics: Emotions and Social Movements. Chicago: University of Chicago Press.

Gorski, Philip S. and Gülay Türkmen-Dervişoğlu. 2013. "Religion, Nationalism, and Violence: An Integrated Approach.” Annual Review of Sociology 39: 193-210.

Göktaş, Mehmed. 2009. "Diyarıbekir Yani Diyarıiman Diyarıislam.” Doğru Haber, March 13-19. Gülen, Fethullah. 2004. Ruhumuzun Heykelini Dikerken Izmir: Nil.

Gülerce, Hüseyin. 2007. “Güneydoğu İçin Yeni Bir Atak." Zaman, November 29.

Güneş, Cengiz. 2012. The Kurdish National Movement in Turkey: From Protest to Resistance. London: Routledge.

Gürbüz, Mustafa. 2009. "Over the Bodies of the T-Girls: The Headscarf Ban as a Secular Effort to Monopolize Islam in Turkey” Middle East Critique 18: 231-49.

— and Mary Bernstein. 2012. "Thou Shall Not Protest!': Multi-Institutional Politics, Strategic Non-Confrontation and Islamic Mobilizations in Turkey" Research in Social Movements, Conflict, and Change 34: 63-91. 
Hamid, Shadi. 2014. Temptations of Power: Islamists and Illiberal Democracy in a New Middle East. Oxford: Oxford University Press.

Harrington, James C. 2011. Wrestling with Free Speech, Religious Freedom, and Democracy in Turkey: The Political Trials and Times of Fethullah Gülen. Lanham, MD: University Press of America.

Hassanpour, Amir. 1998. "Satellite Footprints as National Borders: MED-TV and the Extraterritoriality of State Sovereignty." Journal of Muslim Minority Affairs 18: 53-72.

Heaton, Janet. 2004. Reworking Qualitative Data. Thousand Oaks, CA: Sage.

Hendrick, Joshua. 2013. Gülen: The Ambiguous Politics of Market Islam in Turkey and the World. New York: New York University Press.

Hersant, Jeanne and Alexandre Toumarkine. 2005. "Hometown Organizations in Turkey: An Overview." European Journal of Turkish Studies 2: 1-24.

Hirschler, Konrad. 2001. "Defining the Nation: Kurdish Historiography in Turkey in the 199os." Middle Eastern Studies 37: 145-66.

Hobsbawm, Eric. 1983. "Introduction: Inventing Traditions." Pp.1-14 in The Invention of Tradition, edited by Eric Hobsbawm and Terence Ranger. New York, NY: Cambridge University Press.

İHD, İnsan Hakları Derneği. 2008. Faaliyet Raporu, 2006-2008. Ankara: Dipnot.

— 2009. "İnsan Hakları, Kürt Sorunu ve Türkiye." September 1. http://www.ihd.org.tr/ index.php?option=com_content $\&$ view=article $\&$ id=1863:insan-haklari-kurt-sorunu-veturkiye\&catid=34:el-raporlar\&Itemid=9o Accessed April 12, 2012.

İmset, İsmet. 1992. The PKK: A Report on Separatist Violence in Turkey, 1973-1992. Ankara: Turkish Daily News Publications.

Izady, Mehrdad. 1992. The Kurds: A Concise Handbook. Washington, DC: Taylor and Francis.

Jacoby, Tim. 2005. "Semi-Authoritarian Incorporation and Autocratic Militarism in Turkey." Development and Change 36: 641-65.

Jansen, Robert. 2007. "Resurrection and Appropriation: Reputational Trajectories, Memory Work, and the Political Use of Historical Figures." American Journal of Sociology 112: 953-1007.

Jasper, James M. 1997. The Art of Moral Protest: Culture, Biography, and Creativity in Social Movements. Chicago, IL: University of Chicago Press.

- 2004. "A Strategic Approach to Collective Action: Looking for Agency in Social Movement Choices." Mobilization 9: 1-16.

— 2006. Getting Your Way: Strategic Dilemmas in the Real World. Chicago and London: University of Chicago Press.

- 2011a. "Emotions and Social Movements: Twenty Years of Theory and Research." Annual Review of Sociology 37: 285-303.

- 2011b. "Introduction:From Political Opportunity Structures to Strategic Interaction." Pp. 1-33 in Contention in Context: Political Opportunities and the Emergence of Protest. Edited by Jeff Goodwin and James M. Jasper. Stanford, CA: Stanford University Press.

— 2015. "Introduction: Playing the Game." In Players and Arenas: The Interactive Dynamics of Protest. Edited by Jan W. Duyvendak and James M. Jasper. Amsterdam: Amsterdam University Press.

Jenkins, Gareth. 2008. “Murky Past of Turkey's Gendarmerie Intelligence Emerges in Ergenekon Investigation." Eurasia Monitor September 4. http://www.jamestown.org/programs/gta/ single/?tx_ttnews $\% 5$ Btt_news $\% 5 \mathrm{D}=5138 \&$ tx_ttnews $\% 5$ BbackPid $\% 5 \mathrm{D}=167 \&$ no_cache $=1$ Accessed April 17, 2012. 
Johnston, Hank. 1995. "A Methodology for Frame Analysis: From Discourse to Cognitive Schemata." Pp. 217-45 in Social Movements and Culture, edited by Hank Johnston and Bert Klandermans. Minneapolis, MN: University of Minnesota Press.

Jongerden, Joost. 2009. "Crafting Space, Making People: The Spatial Design of Nation in Modern Turkey." European Journal of Turkish Studies [Online] 1o URL: http://ejts.revues.org/4014 Accessed June 15, 2014.

Jwaideh, Wadie. 2006. The Kurdish National Movement: Its Origins and Development. Syracuse, NY: Syracuse University Press.

Kalyoncu, Mehmet. 2008. A Civilian Response to Ethno-Religious Conflict: The Gülen Movement in Southeast Turkey. New Jersey: Tughra Books.

Kalyvas, Stathis N. 1996. The Rise of Christian Democracy in Europe. Ithaca, NY: Cornell University Press.

— and Kees van Kersbergen. 2010. "Christian Democracy." Annual Review of Political Science 13: 183-209.

Kapmaz, Cengiz. 2011. Öcalan'ın İmralı Günleri. İstanbul: İthaki.

Karagiannis, Emmanuel. 2009. "Hizballah as a Social Movement Organization: A Framing Approach." Mediterranean Politics 14: 365-83.

Kaya, Ayhan. 2013. Europeanization and Tolerance in Turkey: The Myth of Toleration. London: Palgrave Macmillan.

Kaya, Serdar. 2009. "The Rise and Decline of the Turkish 'Deep State': The Ergenekon Case.” Insight Turkey 11: 99-113.

KAYAPINAR. 2006. Diyarbakır Kayapınar Belediyesi 2006 Yılı Faaliyet Raporu. İstanbul: Gün.

— 2010. Diyarbakır Kayapınar Belediyesi 2010 Yılı Faaliyet Raporu. İstanbul: Gün.

Khatib, Lina, Dina Matar, Atef Alshaer. 2014. The Hizbullah Phenomenon: Politics and Communication. Oxford: Oxford University Press.

Kirişci, Kemal. 2011. "The Kurdish Issue in Turkey: Limits of European Union Reform." South European Society and Politics 16: 335-49.

Klandermans, Bert. 1990. "Linking the 'Old' and 'New' Movement Networks in the Netherlands." Pp. 122-36 in Challenging the Political Order: New Social and Political Movements in Western Democracies, edited by Russell J. Dalton and Manfred Kuechler. Oxford: Oxford University Press.

KMD, Kalkınma Merkezi Derneği. 2010. Zorunlu Göç ve Diyarbakır. İstanbul: Gün.

Knudsen, Are. 2005. “Crescent and Sword:The Hamas Enigma." Third World Quarterly 26:1373-88.

Koç, Doğan. 2013. "The Hizmet Movement and the Kurdish Question." Pp. 179-94 in Undersatnding Turkey's Kurdish Question, edited by Fevzi Bilgin and Ali Sarıhan. Lanham, MD: Lexington.

KONDA Araştırma ve Danışmanlık. 2011. Kürt Meselesi'nde Algıve Beklentiler. İstanbul: İletişìm. Koopmans, Ruud. 2003. "A Failed Revolution - But a Worthy Cause." Mobilization 8: 116-19.

Krause, Peter. 2013. "The Political Effectiveness of Non-State Violence: A Two-Level Framework to Transform a Deceptive Debate." Security Studies 22: 259-94.

Kreyenbroek, Philip and Christine Allison (eds.). 1996. Kurdish Culture and Identity. London: Zed Books.

Kriesberg, Louis. 2007. Constructive Conflicts: From Escalation to Resolution. Lanham, MD: Rowman and Littlefield.

Krinsky, John and Ann Mische. 2013. "Formations and Formalisms: Charles Tilly and the Paradox of the Actor." Annual Review of Sociology 39: 1-26. 
Küçük, Mehmet A. 2008. “TZP Kurdi ile Röportaj.” March 22. http://www.kulturelcogulcugundem.com/news.php?nid=720 Accessed May 29, 2014.

Kurban, Dilek, Deniz Yükseker, Ayşe Betül Çelik, Turgay Ünalan, Tamer Aker. 2007. Coming to Terms with Forced Migration: Post-Displacement Restitution of Citizenship Rights in Turkey. İstanbul: TESEV.

Kurt, Mehmet. 2015. Türkiye'de Hizbullah: Din, Şiddet ve Aidiyet. İstanbul: İletişim.

Kurtz, Lester. 2010. "The Mothers of the Disappeared: Challenging the Junta in Argentina, 1977-1983." http://www.nonviolent-conflict.org/index.php/movements-and-campaigns/ movements-and-campaigns-summaries?sobi2Task=sobi2Details\&sobi2 Id=28 Accessed May 17, 2014.

Kuru, Ahmet T. 2007. "Passive and Assertive Secularism: Historical Conditions, Ideological Struggles, and State Policies toward Religion." World Politics 59: 568-94.

- 2009. Secularism and State Policies toward Religion: The United States, France, and Turkey. Cambridge, MA: Cambridge University Press.

Kurzman, Charles. 1996. "Structural Opportunity and Perceived Opportunity in Social Movement Theory: The Iranian Revolution of 1979." American Sociological Review 61: 153-70.

— 1998. "Organizational Opportunity and Social Movement Mobilization: A Comparative Analysis of Four Religious Movements." Mobilization 3: 23-49.

— 2008. "Meaning-Making in Social Movements," Anthropological Quarterly 81: 5-15.

Laçiner, Sedat. 2007. "Combat against Religionist Terrorism in Turkey: Al Qaeda and Turkish Hezbollah Cases.” Turkish Weekly April 2. http://www.turkishweekly.net/article/178/ combat-against-religionist-terrorism-in-turkey-al-qaeda-and-turkish-hezbollah-cases.html Accessed April 17, 2012.

Lamaison, Pierre and Pierre Bourdieu. 1986. "From Rules to Strategies: An Interview with Pierre Bourdieu." Cultural Anthropology 1: 110-20.

Lederach, John Paul. 2003. The Little Book of Conflict Transformation. Interocurse, PA: Good Books.

Levitsky, Olga. 2003. In the Spotlight: Turkish Hezbollah. Washington, DC: The Center for Defense Information.

Levitsky, Sandra. 2007. "Niche Activism: Constructing a Unified Movement Identity in a Heterogeneous Organizational Field." Mobilization 12: 271-86.

Lewellen, Ted. 1989. "Holy and Unholy Alliances: The Politics of Catholicism in Revolutionary Nicaragua." Journal of Church and State 31: 15-33.

Loveman, Mara. 1998. "High-Risk Collective Action: Defending Human Rights in Chile, Uruguay, and Argentina." American Journal of Sociology 104: 477-525.

Maclean, Marie. 1988. Narrative as Performance: The Baudelairean Experiment. London: Routledge.

Mango, Andrew.1999. "Atatürk and the Kurds." Middle Eastern Studies 35: 3-25.

Marcus, Aliza. 2007. Blood and Belief: The PKK and the Kurdish Fight for Independence. New York and London: New York University Press.

Mardin, Serif. 1989. Religion and Social Change in Modern Turkey: The Case of Bediüzzaman Said Nursi. Albany, NY: SUNY Press.

Martin, Andrew. 2010. "Movement Publications as Data: An Assessment of an Underutilized Resource." Research in Social Movements, Conflicts, and Change 30: 271-99.

Martin, John L. 2003. “What is Field Theory?” American Journal of Sociology 109: 1-49. 
Marx, Karl. 1978. "Eighteenth Brumaire of Louis Bonaparte." Pp. 594-617 in The Marx-Engels Reader, edited by Rober C. Tucker. New York, NY: Norton.

Mazrui, Ali. 2000. "Transnational Ethnicity and Subnational Religion in Africa's Political Experience." Pp. 37-63 in Kjell Goldmann, Ulf Hannerz, and Charles Westin (eds.), Nationalism and Internationalism in the Post-Cold War Era. London: Routledge.

McAdam, Doug. 1982. Political Process and the Development of Black Insurgency, 1930-197o. Chicago: University of Chicago Press.

— 1988. Freedom Summer. New York: Oxford University Press.

— 1996. "Conceptual Origins, Current Problems, Future Directions." Pp. 23-40 in Comparative Perspectives on Social Movements: Political Opportunities, Mobilizing Structures, and Cultural Framings.,edited by Doug McAdam, John McCarthy, and Mayer Zald. New York: Cambridge University Press.

— 1999. "Introduction to the Second Edition." In Political Process and the Development of Black Insurgency, 1930-1970. Chicago: University of Chicago Press.

McAdam, Doug, Sidney Tarrow, and Charles Tilly. 1996. “To Map Contentious Politics.” Mobilization 1: 17-34.

— 2001. Dynamics of Contention. Cambridge: Cambridge University Press.

McCammon, Holly J., Courtney Muse, Harmony Newman, and Teresa Terrell. 2007. "Movement Framing and Discursive Opportunity Structures: The Political Successes of the U.S. Women's Jury Movements." American Sociological Review 72: 725-49.

McCarthy, John D. and Mayer N. Zald. 1977. "Resource Mobilization and Social Movements: A Partial Theory." American Journal of Sociology 82: 1212-41.

— 2001. "The Enduring Vitality of Resource Mobilization Theory of Social Movements." Pp. 533-65 in Handbook of Sociological Theory, edited by Jonathan Turner. New York: Kluwer Academic/Plenum.

McDowall, David. 1997. A Modern History of the Kurds. London: I.B. Tauris.

McLellan, David. 1986. Ideology. Minneapolis, MN: University of Minnesota Press.

Mees, Ludger. 2004. "Politics, Economy, or Culture? The Rise and Development of Basque Nationalism in the Light of Social Movement Theory." Theory and Society 33: 311-31.

Melucci, Alberto. 1988. "Getting Involved: Identity and Mobilization in Social Movements." International Social Movement Research 1: 329-48.

Meyer, David and Nancy Whittier. 1994. "Social Movement Spillover." Social Problems 41: 277-98. Meyer, David and Suzanne Staggenborg. 1996. "Movements, Counter-Movements and Political Opportunity." American Journal of Sociology 101: 1628-6o.

— 2012. “Thinking about Strategy." Pp. 3-22 in Strategies for Social Change, edited by Gregory M. Maney, Rachel V. Kutz-Flamenbaum, Deana A. Rohlinger, and Jeff Goodwin. Minneapolis: University of Minnesota Press.

Michel, Thomas. 2008. "Fighting Poverty with Kimse Yok Mu?" Paper Presented at international conference, Islam in the Age of Global Challenges: Alternative Perspectives of the Gülen movement, Georgetown University, Washington, DC. November 14-15.

Michels, Robert. 1962 [1915]. A Sociological Study of the Oligarchical Tendencies of Modern Democracy. New York: Free Press.

Minkoff, Debra C. 1995. "Interorganizational Influences on the Founding of African American Organizations, 1955-1985." Sociological Forum 10: 51-79.

— 1997. "The Sequencing of Social Movements," American Sociological Review 62: 779- 99.

— 1999. "Bending with the Wind: Strategic Change and Adaptation by Women's and Racial Minority Organizations." American Journal of Sociology 104: 1666-1703. 
Mische, Ann. 2011. "Relational Sociology, Culture, and Agency." Pp. 80-97 in The Sage Handbook of the Social Network Analysis, edited by John Scott and Peter Carrington. London: Sage.

Mizell, Aland. 2009. "Fethullah Gülen versus Said Kurdi." Kurdish Media Online May 5. http:// www.kurdmedia.com/article.aspx?id=15685 Accessed November 11, 2009.

Molina, Fernando. 2011. "The Reign of Christ over the Nation: The Basque Question in the Spanish Republic, 1931-1936." National Identities 13: 17-33.

Mottl, Tahi. 1980. "The Analysis of Countermovements," Social Problems 27:620-35.

Munson, Ziad W. 2009. The Making of Pro-Life Activists: How SocialMovement Mobilization Works. Chicago, IL: University of Chicago Press.

Natali, Denise. 2010. The Kurdish Quasi-State: Development and Dependency in Post-Gulf War Iraq. Syracuse, NY: Syracuse University Press.

Nepstad, Sharon E. 2004. "Religion, Violence, and Peace-Making." Journal for the Scientific Study of Religion 43: 297-301.

- 2008. Religion and War Resistance in the Plowshares Movement. New York: Cambridge University Press.

- 2011. Nonviolent Revolutions: Civil Resistance in the Late $20^{\text {th }}$ Century. Oxford: Oxford University Press.

Nuhoğlu, Cudi. 2011. “TC ve PKK'nın Kuyruk Acısı.” February 17. http://huseynisevda.biz/news. php?readmore=1051 Accessed February 23, 2011.

Öcalan, Abdullah. 1999. "Kemalist Tarih, Altenatifleri YokEtme Tarihidir." Serxwebûn 206:12-16. — 2003. Özgür İnsan Savunması. İstanbul: Mem.

- 2007. Prison Writings: The Roots of Civilisation. Translated by Klaus Happel. London: Pluto Press.

— 2008a. "Ergenekoncular Fazla İçerde Kalmaz." Görüşme Notları. September 3.

— 2008b. "AKP Hizbullah'ın Resmi Biçimidir." Görüşme Notları. October 3.

— 2009a. "Devlet Kendi Kürdünü Yaratıyor." Görüşme Notları. January 4.

— 2009b. "ABD Ergenekoncuları Çöpe Attı." Görüşme Notları. January 10.

— 2009c. "Davos Çıkışı SP ve Kürt Oylarına Yönelik." February 6. Gündem Online http://www. gundem-online.net/haber.asp?haberid=67745. Accessed March 12, 2010.

— 2009d. "Ben Kürtlerin Sözcüsüyüm." Görüşme Notları. June 26.

— 2011a. "Hizbullahçıların Bırakılması Tesadüf Değildir.” Görüşme Notları. January 9.

— 2011b. "80'de Gladyo Millileştirildi." January 21.

— 2011c. "Bu Son Şans." Görüşme Notları. May 11.

Oliver, Pamela E. 2003. "Mechanisms of Contention." Mobilization 8: 119-22.

— and Hank Johnston. 2000. "What a Good Idea: Frames and Ideologies in Social Movements Research." Mobilization 5: 37-54.

Olson, Mancur. 1965. The Logic of Collective Action. Cambridge, MA: Harvard University Press.

Olson, Robert. 1989. The Sheikh Said Rebellion and the Emergence of Kurdish Nationalism, 1880 1925. Austin, TX: University of Texas Press.

- 2009. Blood, Beliefs and Ballots: The Management of Kurdish Nationalism in Turkey. Costa Mesa, CA: Mazda.

Olzak, Susan. 1992. The Dynamics of Ethnic Competition and Conflict. Stanford, CA: Stanford University Press.

— 2006. The GlobalDynamics of Racial and Ethnic Mobilization. Stanford, CA: Stanford University Press. 
— and Emily Ryo. 2007. "Organizational Diversity, Vitality, and Outcomes in the African American Civil Rights Movement." Social Forces 85: 1561-91.

Ongun, Selin. 2010. "Gülen Cemaati Hakkari'yi Anlatıyor." T24: Bağımsız İnternet Gazetesi September 20. http://t24.com.tr/haber/gulen-cemaati-hakkariyi-anlatiyor/99542 Accessed April 15, 2012.

Oran, Baskın. 2010. Türkiyeli Kürtler Üzerine Yazılar. İstanbul: İletişim.

Özbey, Sait. 2009. Kürtlerve İslami Kurtuluş. İstanbul: Dua.

Özcan, Ali Kemal. 2006. Turkey's Kurds: A Theoretical Analysis of the PKK and Abdullah Öcalan. New York: Routledge.

Pandya, Sophia. "Hizmet and the Kurdish Question in Southeastern Turkey and Iraq." Turkish Journal of Politics 5: 73-94.

Pappé, Ilan. 2006. "The Bridging Narrative Concept." Pp. 194-204 in Israeli and Palestinian Narratives of Conflict: History's Double Helix, edited by Robert Rotberg, Bloomington: Indiana University Press.

Platt, Gerald M. and Rhys H. Williams. 2002. "Ideological Language and Social Movement Mobilization: A Sociolinguistic Analysis of Segregationists' Ideologies." Sociological Theory 20: $328-59$.

Polletta, Francesca. 1997. "Culture and Its Discontents: Recent Theorizing on Culture and Protest." Sociological Inquiry 67: 431-50.

— 1998a. "It Was Like a Fever...' Narrative and Identity in Social Protest." Social Problems 45: 137-59.

— 1998b. "Contending Stories: Narrative in Social Movements." Qualitative Sociology 21: 419-46.

— 1999. "Snarls, Quacks, and Quarrels: Culture and Structure in Political Process Theory." Sociological Forum 14: 67-74.

— 2004. "Culture in and Outside Institutions" Pp. 161-86 in Authority in Contention, edited by Daniel Myers and Dan Cress. Oxford: Elsevier.

— 2006. It Was Like a Fever: Storytelling in Protest and Politics. Chicago and London: University of Chicago Press.

Przeworski, Adam. 1985. Capitalism and Social Democracy. Cambridge, UK: Cambridge University Press.

Romano, David. 2002. "Modern Communications Technology in Ethnic Nationalist Hands: The Case of the Kurds." Canadian Journal of Political Science 35: 127-49.

— 2006. The Kurdish Nationalist Movement: Opportunity, Mobilization, and Identity. New York: Cambridge University Press.

— 2014. "When the Enemy of My Enemy Turn Outs to Be ... Also My Enemy," Rudaw Feb 6.

Ross, Marc H. 2007. Cultural Contestation in Ethnic Conflict. Cambridge: Cambridge University Press.

- (ed.) 2009. Culture and Belonging in Divided Societies: Contestation and Symbolic Landscapes. Philadelphia: University of Pennsylvania Press.

Rubinstein, Richard. 2008. "Research and Practice in Conflict and Peace Studies." Research in Social Movements, Conflict, and Change 29: 281-93.

Rucht, Dieter. 2003. "Overcoming the 'Classical Model?" Mobilization 8: 112-16.

Ryan, Stephen. 2007. The Transformation of Violent Intercommunal Conflict. Aldershot, UK: Ashgate. 
Sahlins, Peter. 1989. Boundaries: The Making of France and Spain in the Pyrenees. Berkeley and Los Angeles: University of California Press.

Sarigil, Zeki. 2007. Endogenizing Institutions. PhD dissertation, University of Pittsburg.

- 2010. "Curbing Kurdish Ethno-nationalism in Turkey: An Empirical Assessment of Pro-Islamic and Socio-Economic Approaches." Ethnic and Racial Studies 33: 533-53.

— and Ömer Fazlıŏglu. 2013. "Religion and Ethno-nationalism: Turkey's Kurdish Issue." Nations and Nationalism 19: 551-71.

Saritoprak, Zeki and Ali Ünal. 2005. “An Interview with Fethullah Gülen.” The Muslim World 95: 447-67.

Sartori, Giovanni. 1969. "Politics, Ideology, and Belief Systems." American Political Science Review 63: 398-411

Sawchuk, Dana. 1997. "The Catholic Church in the Nicaraguan Revolution: A Gramscian Analysis." Sociology of Religion 58: 39-51.

Schmidt, Steffen W., James C. Scott, Carl Lande, Laura Guasti (eds.). 1977. Friends, Followers, and Factions: A Reader in Political Clientelism. Berkeley: University of California Press.

Schudson, Michael. 1989. "The Present in the Past versus the Past in the Present." Communication 11: $105^{-13}$.

Schumpeter, Joseph A. 1942. Capitalism, Socialism, and Democracy. New York: Harper \& Brothers.

Schwedler, Jillian. 2006. Faith in Moderation: Islamist Parties in Yemen and Jordan. New York: Cambridge University Press.

Scott, James C. 1990. Domination and the Arts of Resistance: Hidden Transcripts. New Haven: Yale University Press.

Seferoğlu, Şükrü K. 1982. Anadolunun ilk Türk sakinleri Kürtler. Ankara: Türk Kültürünü Araştırma Enstitüsü.

Sevindi, Nevval. 2008. Contemporary Islamic Conversations: M. Fethullah Gülen on Turkey, Islam, and the West. Translated by Abdullah Antepli. Albany, NY: SUNY Press.

Sewell, William H. 1992. "A Theory of Structure: Duality, Agency, and Transformation." American Journal of Sociology 99: 1-29.

Smith, Jackie. 1995. "Transnational Political Processes and the Human Rights Movement." Research in Social Movements, Conflict, and Change 18: 185-220.

— and Hank Johnston (eds.). 2002. Globalization and Resistance. Lanham, MD: Rowman and Littlefield.

Smithey, Lee A. 2011. Unionists, Loyalists, and Conflict Transformation in Northern Ireland. Oxford and New York: Oxford University Press.

Snow, David A. 2004. "Framing Processes, Ideology, and Discursive Fields." Pp. 380-412 in The Blackwell Companion to Social Movements, edited by David A. Snow, Sarah Soule and Hanspeter Kriesi. Malden, MA; Oxford, UK: Blackwell.

—, E. Burke Rochford, Jr., Steven K. Worden, Robert D. Benford. 1986. "Frame Alignment Processes, Micromobilization, and Movement Participation." American Sociological Review 51: 464-81.

Steinberg, Marc W. 1993. "Rethinking Ideology: A Dialogue with Fine and Sandstrom from a Dialogic Perspective." Sociological Theory 11: 314-20.

— 1998. "Tilting the Frame: Considerations on Collective Action Framing from a Discursive Turn." Theory and Society 27: 845-72.

- 1999. "The Talk and Back Talk of Collective Action: A Dialogic Analysis of Repertoires of Discourse among Nineteenth-Century English Cotton Spinners." The American Journal of Sociology 105: 736-80. 
Steinman, Erich. 2012. "Settler Colonial Power and the American Indian Sovereignty Movement: Forms of Domination, Strategies of Transformation." American Journal of Sociology 117: 1073-1130.

Stepan-Norris, Judith and Maurice Zeitlin. 2003. Left Out: Reds and America's Industrial Unions. Cambridge and New York: Cambridge University Press.

Stepan-Norris, Judith and Caleb Southworth. 2010. "Rival Unionism and Membership Growth in the United States, 1900 to 2005: A Special Case of Inter-organizational Competition." American Sociological Review 75: 227-51.

Şahin, Mustafa G. 2011. "Said Nursi and the Nur Movement in Turkey: An Atomistic Approach." DOMES: Digest of Middle East Studies 20: 226-41.

Şahiner, Necmettin. 1998. Bilinmeyen Taraflarıyla Bediuzzaman Said Nursi. $13^{\text {th }}$ edition. İstanbul: Nesil.

Şakir, Muhammed. 2007. Üstad Bediüzzaman Said Nursi: Hayatı, Mücadelesi, Eserleri. Istanbul: Dua Yayıncılık.

Şeyhanzade, Muhammed S. 2007. Bediüzzaman Said-i Kürdi'nin Lisanından Orta Şarkta Milletlerin Yeniden Dirilişi: Ittiba-ı Kur'an. Istanbul: Tenvir Neşriyat.

Şimşek, Yılmaz. 2006. Impact of Terrorism on Migration Patterns in Turkey. Ph.D. Dissertation, Virginia Commonwealth University.

Taheri, Amir. 2008. The Persian Night:Iran under the Khomeinist Revolution. New York: Encounter Book.

Tan, Altan. 2009. Kürt Sorunu: Ya Tam Kardeşlik Ya Hep Birlikte Kölelik. Istanbul: Timaş.

Taneri, Aydın. 1983. Türkistanlı bir Türk boyu Kürtler. Ankara: Türk Kültürünü Araştırma Enstitüsü.

Taş, Hakk1. 2011. Politics of Re-building Secular Hegemony and The Subject in Post-1997 Turkey. Ph.D. Dissertation. Bilkent University, Ankara.

Taylor, Verta. 1998. “Feminist Methodology in Social Movements Research.” Qualitative Sociology 21: $357-79$.

— 2003. "Plus ça Change, Plus C'est la Même Chose." Mobilization 8:122-26.

Tee, Caroline and David Shankland. 2013. “Said Nursi's Notion of 'Sacred Science': Its Function and Application in Hizmet High School Education." Sociology of Islam 1: 209-32.

Tezcür, Güneş M. 2009. "Kurdish Nationalism and Identity in Turkey: A Conceptual Reinterpretation." European Journal of Turkish Studies [Online], 10 | 2009, Accessed April 11, 2011. URL: http://ejts.revues.org/index40o8.html.

- 2010a. Muslim Reformers in Iran and Turkey: The Paradox of Moderation. Austin, TX: University of Texas Press.

— 2010b. "When Democratization Radicalizes: The Kurdish Nationalist Movement in Turkey." Journal of Peace Research 47: 775-89.

- 2013. "Prospects for the Resolution of the Kurdish Question: A Realist Perspective." Insight Turkey 15: 69-84.

— and Sabri Çiftçi. 2014. "Radical Turks," Foreign Affairs Nov 11.

Tilly, Charles. 1978. From Mobilization to Revolution. Reading, MA: Addison-Wesley.

- 1995. Popular Contention in Great Britain, 1758-1834. Cambridge, Mass.: Harvard University Press.

— 1999. "Conclusion: From Interactions to Outcomes in Social Movements." Pp. 253-71 in How Social Movements Matter, edited by Marco Giugni, Doug McAdam, and Charles Tilly, Minneapolis: University of Minnesota Press.

— 2005. Trust and Rule. New York: Cambridge University Press. 
— 2006a. Why? Princeton, NJ: Princeton University Press.

— 2006b. "Afterword: Political Ethnography as Art and Science." Qualitative Sociology 29:409-12.

- 2007. Democracy. Cambridge, UK: Cambridge University Press.

- 2008. Credit and Blame. Princeton, NJ: Princeton University Press.

— 2010a. "The Blame Game." The American Sociologist 41: 382-89.

- 2010b. "Another View of Conventions." The American Sociologist 41: 390-99.

Tittensor, David. 2014. The House of Service: The Gülen Movement and Islam's Third Way. New York: Oxford University Press.

Todorov, Tzvetan. 1984. Mikhail Bakhtin: The Dialogical Principle. Minneapolis, MN: University of Minnesota Press.

Toksöz, Fikret. 1983. “Dernekler." Pp. 366-78 In Cumhuriyet Dönemi Türkiye Ansiklopedisi 2 Istanbul: İletişim Yayınları.

Trejo, Guillermo. 2009. "Religious Competition and Ethnic Mobilization in Latin America: Why the Catholic Church Promotes Indigenous Movements in Mexico." American Political Science Review 103: 323-42.

Turam, Berna. 2004. "A Bargain between the Secular State and Turkish Islam: Politics of Ethnicity in Central Asia." Nations and Nationalism 10: 353:74.

- 2007. Between Islam and the State: The Politics of Engagement. Stanford, CA: Stanford University Press.

Turan, Abdülkadir. 20o9. “Kuran'ı Kapa, Kadınları Aç.” Doğru Haber, March 13-19.

Turgut, Pelin. 2006. “Senior General 'Stoked Kurdish Conflict to Keep Turkey Out of EU'.” The Independent March 8.

Türköne, Mümtaz'er. 2009. “Ergenekon Efsanesi Kime Ait?” Zaman, February 22.

Turner, Ralph and Lewis Killian. 1972. Collective Behavior. Englewood Cliffs, NJ: Prentice Hall.

Tutar, Cemal. 20og. "6 Nolu Ağır Ceza Mahkemesi Başkanlığına Esas Hakkındaki Son Savunma.” Unpublished Document. Mustazaf-Der Archives, Diyarbakır.

Uğur, Etga. 2013. “Organizing Civil Society: The Gülen Movement's Abant Platform.” Pp. 47-64 in The Muslim World and Politics in Transition: Creative Contributions of the Gülen Movement edited by Greg Barton, Paul Weller, and Ihsan Yilmaz. London: Bloomsbury.

Ünver, Akın. 2009. Turkey's Deep State and the Ergenekon Conundrum. The Middle East Institute Policy Brief, No: 23.

Uslu, Emrullah. 2007. “From Local Hizbollah to Global Terror: Militant Islam in Turkey,” Middle East Policy XIV: 124-41.

- 2009. The Transformation of Kurdish Political Identity in Turkey: Impact of Modernization, Democratization, and Globalization. Ph.D. Dissertation. University of Utah.

Vahide, Şükran. 2003. “Toward an Intellectual Biography of Said Nursi." Pp. 1-33 In Islam at the Crossroads: On the Life and Thought of Bediuzzaman Said Nursi, edited by Ibrahim Abu-Rabi. Albany: State University of New York Press.

Van Bruinessen, Martin. 1992. Agha, Shaikh, and State: The Social and Political Structures of Kurdistan. London: Zed Books.

- 2000. "The Kurds and Islam," in Mullas, Sufis and Heretics: The Role of Religion in Kurdish Society: Collected Articles, edited by M. van Bruinessen, Istanbul: The Isis Press.

— 2004. "The Kurdish movement: issues, organization, mobilization," On the Waterfront, Newsletter of the Friends of the International Institute for Social History 8: 10-12.

— 2005. "İsmail Beşikçi: Turkish Sociologist, Critic of Kemalism, and Kurdologist." Journal of Kurdish Studies 5:19-34. 
Van Dyke, Nella, Sarah Soule, and Verta Taylor. 2004. "The Targets of Social Movements: Beyond a Focus on the State." Research in Social Movements, Conflict, and Change 25: 27-51.

Volkan, Vamik. 1998. Bloodlines: From Ethnic Pride to Ethnic Terrorism. Boulder, CO: Westview.

- 2006. Killing in the Name of Identity: A Study of Bloody Conflicts. Charlottesville, VA: Pitchstone Publishing.

Voss, Kim and Michelle Williams. 2012. "The Local in the Global: Rethinking Social Movements in the New Millennium." Democratization 19: 352-77.

Wacquant, Loic. 1989. "Towards a Reflexive Sociology: A Workshop with Pierre Bourdieu." Sociological Theory 7: 26-63.

Walder, Andrew G. 2009. "Political Sociology and Social Movements." Annual Review of Sociology 34: 393-412.

Wallerstein, Immanuel. 1976. The Modern World-System: Capitalist Agriculture and the Origins of the European World-Economy in the Sixteenth Century. New York: Academic Press.

Wang, Chin-Shou and Charles Kurzman. 2007. "Dilemmas of Electoral Clientalism: Taiwan, 1993." International Political Science Review 28: 225-45.

Watts, Nicole. 1999. "Allies and Enemies: Pro-Kurdish Parties in Turkish Politics, 1990-1994." International Journal of Middle East Studies 31: 631-56.

— 2006. "Activists in Office: Pro-Kurdish Contentious Politics in Turkey." Ethnopolitics 5:125-44.

- 2010. Activists in Office: Kurdish Politics and Protest in Turkey. Seattle, WA: University of Washington Press.

Wendt, Alexander. 1999. Social Theory of International Politics. Cambridge, MA: Cambridge University Press.

Westby, David L. 2002. "Strategic Imperative, Ideology, and Frame." Mobilization 7: 287-304.

White, Hayden. 1987. The Content of the Form: Narrative Discourse and Historical Representation. Baltimore: Johns Hopkins University Press.

White, Paul. 200o. Primitive Rebels or Revolutionary Modernizers: The Kurdish National Movement in Turkey. London: Zed Books.

- 2015. The PKK: Coming Down from the Mountains. London: Zed Books.

White, Robert. 1989. "From Peaceful Protest to Guerilla War: Micromobilization of the Provisional Irish Republican Army." American Journal of Sociology 94: 1277-1302.

Wickham, Carrie R. 2004. "The Path to Moderation: Strategy and Learning in the Formation of Egypt's Wasat Party." Comparative Politics 36: 205-28.

Wickham-Crowley, Timothy. 1989. "Winners, Losers, and Also-Rans: Toward a Comparative Sociology of Latin American Guerilla Movements." Pp. 132-81 in Power and Popular Protest: Latin American Social Movements, edited by Susan Eckstein, Berkeley and Los Angeles: University of California Press.

Wilson, John. 1973. Introduction to Social Movements. New York: Basic Books.

Wimmer, Andreas. 2008. "The Making and Unmaking of Ethnic Boundaries: A Multi-level Process Theory." American Journal of Sociology 113: 970-1022.

— 2013. Ethnic Boundary Making:Institutions, Power, Networks. Oxford: Oxford University Press.

Woehrle, Lynne, Patrick Coy, and Gregory Maney. 2008. Contesting Patriotism: Culture, Power, and Strategy in the Peace Movement. Lanham, MD: Rowman \& Littlefield.

Woodworth, Paddy. 2001. Dirty War, Clean Hands: ETA, the GAL and Spanish Democracy Dublin: Cork University Press.

Yavuz, Hakan. 2003. Islamic Political Identity in Turkey. New York: Oxford University Press. 
- 2012. Toward an Islamic Enlightenment: The Gülen Movement. New York: Oxford University Press.

— and Nihat A. Özcan. 20o6. “The Kurdish Question and Turkey's Justice and Development Party," Middle East Policy XIII: 102-19.

Yeğen, Mesut. 1996. "The Turkish State Discourse and the Exclusion of Kurdish Identity." Middle Eastern Studies 32: 216-29.

— 1999. “The Kurdish Question in Turkish State Discourse." Journal of Contemporary History 34: $555^{-68}$.

Yıldız, Ahmet. 2001. 'Ne Mutlu Türküm Diyebilene’: Türk Ulusal Kimliğinin Etno-Kültürel Sınırları, 1919-1938. İstanbul: İletişim.

Yörük, Erdem. 2012. "Welfare Provision as Political Containment: The Politics of Social Assistance and the Kurdish Conflict in Turkey." Politics \& Society 40: 517-47.

Yükleyen, Ahmet. 2012. Localizing Islam in Europe: Turkish Islamic Communities in Germany and the Netherlands. Syracuse, NY: Syracuse University Press.

Yükseker, Deniz. 2007a. "Research Findings on Internal Displacement in Turkey: National Reports.” Pp. 145-58. In Coming to Terms with Forced Migration:Post-Displacement Restitution of Citizenship Rights in Turkey Kurban, Dilek, Deniz Yükseker, Ayşe Betül Çelik, Turgay Ünalan, Tamer Aker. İstanbul: TESEV.

— 2007b. "Internal Displacement in the Province of Diyarbakır: Return, Urban Issues, and Implementation of the Compensation Law." Pp. 172-205. In Coming to Terms with Forced Migration: Post-Displacement Restitution of Citizenship Rights in Turkey Kurban, Dilek, Deniz Yükseker, Ayşe Betül Çelik, Turgay Ünalan, Tamer Aker. İstanbul: TESEV.

Yüksel, Metin. 2009. “A 'Revolutionary’ Kurdish Mullah from Turkey: Mehmed Emin Bozarslan and His Intellectual Evolution." The Muslim World 99: 356-8o.

Zald, Mayer N. and John D. McCarthy. 1980. "Social Movement Industries: Cooperation and Conflict amongst Social Movement Organizations.” Pp. 1-2o in Research in Social Movements, Conflict, and Change, vol. 3, edited by Louis Kriesberg. Greenwich, Conn.: JAI Press.

Zald, Mayer N. and Bert Useem. 1987. "Movement and Countermovement Interaction: Mobilization, Tactics, and State Involvement." Pp. 247-271 in Social Movements in an Organizational Society, edited by Mayer N. Zald and John D. McCarthy. New Brunswick, NJ: Transaction.

Zerubavel, Eviatar. 1996. "Social Memories: Steps to a Sociology of the Past." Qualitative Sociology 19: $283-99$.

Zinar, Zeynelabidîn. 1998. "Medrese education in northern Kurdistan" translated and annotated by Martin van Bruinessen. Les Annales de l'Autre Islam 5 .

Zubaida, Sami. 1992. "Islam, the State and Democracy: Contrasting Conceptions of Society in Egypt." Middle East Report 179: 2-10.

\section{Periodicals and Websites}

ANF, Ajansa Nûçeyan a Firatê. 2007. "Fethullah Gülen'den Skandal Risale Çarpıtmaları." September 12. http://www.firatnews.eu/arsivo508/pictures/firatnews/28578/autoblank. htm Accessed April 15, 2012.

— 2008. "YDG-M Genç Komitesi'nden Kampanya Destek." December, 28. http://www.firatnews. tv/index.php?rupel=nuce\&nuceID=239 Accessed July 6, 2011.

— 2009. "Halk İnisiyatifi'nden Gülen Cemaatine Sert Uyarı." April, 18. http://www.firatnews. tv/index.php?rupel=nuce\&nuceID=6349, Accessed July 2, 2011. 
— 2010a. "Halk İnisiyatifi'nden Gülen Tarikatı'na Sert Uyarı." September, 8. http://www. firatnews.tv/index.php?rupel=nuce\&nuceID=32626, Accessed July 2, 2011.

— 2010b. “Kalkan: Devletin İbadeti Gasp Etmesine Firsat Verilmemeli." October 25. http://www. firatnews.org/index.php?rupel=nuce\&nuceID=35072 Accessed July 25, 2011.

— 2011a. "Tesettürlü bir Gerilla." June 23. http://www.firatnews.tv/index.php?rupel=nuce\& nuceID $=45408$ Accessed July 8, 2011.

— 2011b. “Rusya'da Zeynep Kınacı'yı Anma Etkinlikleri.” July, 1. http://www.firatnews.tv/index. php?rupel=nuce\&nuceID=45879 Accessed July 2, 2011.

— 2012. “Kongra-Gel: Kürt kadınlar Demokratik Konfederalizm'in Öncü Gücü.” March 5. http:// firatnews.tv/index.php/index.php?rupel=nuce\&nuceID=59130 Accessed April 10, 2012.

— 2013. "TZP Kurdi Conference: Mother Tongue Education is an Indispensable Right." August 26. http://en.firatnews.com/news/news/tzp-kurdi-conference-mother-tongue-education-is-anindispensable-right.htm Accessed May 30, 2014.

— 2014a. "TZP Kurdi Organizing Events to Mark International Mother Language Day." Feb 17. http://en.firatnews.com/news/news/tzp-kurdi-organizing-events-to-mark-internationalmother-language-day.htm Accessed May 29, 2014.

— 2014b. "Öcalan: There is a Need for a New Institutionalising of Islam in Kurdistan." May 10. http://en.firatnews.com/news/news/Öcalan-there-is-a-need-for-a-new-institutionalisingof-islam-in-kurdistan.htm Accessed May 26, 2014.

Anonymous. 2008. “Ergenekon Tipi Yapılanmaların Hizbullah’a Karşı Faaliyetleri.” August 21. http://huseynisevda.biz/articles.php?article_id=82 Accessed February 19, 2011.

BBC. 2014. “Analysis: Power of Turkey's Fethullah Gülen." Jan 27. http://www.bbc.com/news/ world-europe-25910079. Accessed February 28, 2015.

BBC Türkçe. 2013. "BDP: Islam Kongresi El-Kaide’ye Karşı Bir Girişim." October 21. http:// www.bbc.co.uk/turkce/haberler/2013/10/131021_sebahat_tuncel_roportaj.shtml Accessed October 23, 2013.

Bianet. 2011. "Sivil Cuma Namazı' Kılındı." April 8. http://bianet.org/bianet/siyaset/129155-sivilcuma-namazi-kilindi Accessed July 25, 2011.

— 2014. "Seçimlere Kürt Kadınların Penceresinden Bakmak." May 3. http://bianet.org/biamag/ siyaset/155393-secimlere-kurt-kadinlarin-penceresinden-bakmak Accessed May 20, 2014.

Bugün. 2011. “Apo'dan BDP’ye Hizbullah Çağrısı.” January 9.

Ciwanenazad. 2009. “Kürdistan'da Onbinlerce Kadın Meydanlara İndi.” March 8. http://www. ciwanenazad.org/haber-46062.html Accessed July 6, 2011.

CSM, Christian Science Monitor. 2009. "Religious Kurds Become Key Vote in Turkey." January 5.

Cumhuriyet. 2015. "Bu Hükümet ile 50 Yll Müzakere Edilse Bile Çözüm Sonucu Almak Gerçekçi Değil." January 18.

DIHA, Dicle Haber. 2014. “Roboski Anıtı Önünde Adalet Arayışı.” May 11. http://www.diclehaber. $\mathrm{com} / \mathrm{tr} /$ news/content/view/400911?from=3305028514 Accessed May 20, 2014.

Diyarbakır Haber. 2011. "Yağmura Rağmen 'Sivil Cuma'." April 22. http://www.diyarbakirhaber. gen.tr/haber-136o-Yagmur-Ragmen-Sivil-cuma.html Accessed July 25, 2011.

Doğru Haber. 2009. "Saygınızda Batacaksınız." March 13-19.

— 2011. "Tesettür Seferberliği Başlattı.” July 8.

Haber24. 2009. "Fethullah Gülen'den Kürtçe Kanal!" August 31. http://www.haber24.com/ Guncel/1-59923/Fethullah-Gulen-den-Kurtce-kanal.html Accessed December 29, 2009.

HaberYek. 2011. "Mele Eşref'in İnsafsızlığı.” November 1. http://www.haberyek.com/news_detail. php?id=605 Accessed February 16, 2012.

HDN, Hurriyet Daily News. 2010. "PKK Leader Hints at Alliance with Turkish Religious Group.” December 9. http://www.hurriyetdailynews.com/n. 
php?n=call-of-alliance-from-pkk-leader-to-fettullah-gulen-2010-12-o9 Accessed December 29, 2010.

HMNP, Hizmet Movement News Portal. 2013. "Will Gülen Movement Schools Offer Kurdish Medium Education?” October 7 http://hizmetnews.com/6025/will-Gülen-movementschools-offer-kurdish-medium-education/\#.VMf8T_7F-o- Accessed February 21, 2015.

Hürriyet. 2008. "Güneydoğu'ya 'Nur' Yağıyor." March 29.

— 2013. "BDP Heyeti Öcalan'in Mesajını Açıladı." October 15.

Hürseda. 2009. "Apo Kürtlerin Atatürküdür." http://hurseda.net/Politika/892--Apo-KurtlerinAtaturkudur.html Accessed July 7, 2011.

ILKHA, İlke Haber Ajansı. 20oga. "Namusumuz Özgürlüğümüzdür' Propagandasına Tepki.” http://www.ilkehaberajansi.com.tr/haber/namusumuz-ozgurlugumuzdur-propagandasinatepki.html Accessed July 6, 2011.

— 2009b. “Mustazaf-Der'den 6 bin Aileye Kurban Yardımı." December 2. http://www.ilkehaberajansi.com.tr/haber/mustazaf-derden-6-bin-aileye-kurban-yardimi.html Accessed July 10, 2011.

— 2014. “Kutlu Doğum Siyer Sinavı Hazırlıkları Tamamlandı." May 22.

$K M$, Kurdish Media. 2009. "PKK Spokesman: During Elections in Diyarbakır Kurds Give a Lesson to Erdoğan.” January 4. http://www.kurdmedia.com/article.aspx?id=15328 Accessed May 10, 2009.

Kurdistan Post. 2010. “Saidi Kürdi'nin Romanı, Son Derviş.” January 30. http://www.kurdistanpost.com/News-file-article-sid-34613.html Accessed March 26, 2010.

Milat. 2013. “Lozan Çöktü.” March 22.

Milliyet. 2010. “PKK'nın Şehir Yapılanması Baydemir'i Yargıladı.” February 16.

— 2011. "CHP’li İnce: Kimin Şerefsiz Olduğu Ortaya Çıktı." Milliyet, Sep 16.

— 2014. “İki Parti'nin 'Kutlu Doğum' Rekabeti.” February 11.

Newroz. 2009. "Son Derviş ya da Said Gerçeği." October 1.

Özgür Gündem. 2008. “Kürt İmamlar Örgütlendi.” June 2.

— 2009. "Bediüzzaman'ın Çı̆̆lıkları." August 17.

— 2011. “AKP'ye Oy Felaket Getirir." June 10.

Posta. 2012. "Erdoğan: Bu Teröristler Zerdüşt." October 20.

Radikal. 2006. "Nice Çetelere." June 2.

— 2008a. "DTP İmamı' Gözaltında.” March 1.

— 2008b. "Türk'ün Konuşması DTP'yi Karıştırdı." May 15.

— 2008c. "DTP'li Ayna: AKP Fethullah Gülen'e Yaslanıyor." December 3.

— 2009a. "DTP’li Abdil: Hamile Kadınlarımızın Karınlarını Kestiler.” January 14.

— 2009b. "Türk: Genelkurmay ve Başbakan Ergenekon Pazarlığı Mı Yaptı?” January 20.

— 2009c. "Diyarbakır'da Camilerde Kürtçe Mevlit Okutulacak." May 26.

- 2011. “Şivan Perver PKK'ya Sert Çıktı.” March 30.

— 2013a. "Başbakan Erdoğan Demokratikleşme Paketini Açıkladı." September 30.

— 2013b. "BDP'li Altan Tan: Kürt Kongresinde Gülen Cemaati de Yer Almalı." October 22.

Referans. 2010. "Diyarbakır'da Gıda Bankasına Valilik Engeli." January 12.

Rudaw. 2013. "Dive Tirkiye Bibe Parezvana Mafen Kurdan Li Seranseri Dinyaye." June 30, 2013 http://rudaw.net/kurmanci/interview/30062013 Accessed February 10, 2015.

Sabah. 2011. "Kürt Aydınlardan PKK'ya İsyan." March 10.

Taraf. 2010. "Dağ'da PKK Mahkemesi." September 22.

TimeTurk. 2012. "Mustazaf-Der Resmen Kapatıldı." May 11. http://www.timeturk.com/ tr/2012/05/11/mustazaf-der-resmen-kapatildi.html\#.U35bKPldUfU Accessed May 22, 2014, 2014. 
— 2014. "Davutoğlu'ndan Şok: PKK ve Paralel Yapı Ortak Çalışıyor." Dec 9. http://www. timeturk.com/tr/2014/12/o9/Davutoğlu-ndan-sok-pkk-ve-paralel-yapi-ortak-calisiyor.html\#. VMIVQWjF-o8 Accessed February 22, 2015.

Today's Zaman. 2007. "Kimse Yok Mu to Distribute Meat to Tens of Thousands in Southeast." Dec 12.

- 2014. "Ankara Forces Arbil to Close Turkish Schools in KRG." March 11.

Tulyum. 2008. “AK Parti'de 'Eleştirdikleri Ne Varsa' Artık Kendileri de Yapıyorlar.” Dec 7. http://www.tulyum.com/haber-ak-partide-elestirdikleri-ne-varsa-artik-kendileri-deyapiyorlar-1640/ Accessed July 10, 2011.

Vatan. 2008. “DTP Said-i Nursi'ye İade-i İtibar İstiyor.” March 28.

Yeni Aktüel. 2007. “Gülen Hareketi PKK'ya Karşı.” November 22.

Yüksekova Haber. 2011. "Sivil Cuma'da Erdoğan'a Tepki.” April 8. http://www.yuksekovahaber. com/haber/sivil-cumada-erdogana-tepki-49554.htm Accessed July 25, 2011.

Zaman. 2008a. "Sevgi Gülpembe Derneği Kadınlar Gününü Seminerle Kutladı." March 9.

— 2008b. "DTP Diyarbakır'da AK Parti'yi Model Alıyor." September 20.

— 2009. "Çağdaş Yaşam’ın Burs Verdiği PKK’lıların Listesi KCK Baskınında Çıktı.” April 18.

— 2013a. "Batman'da Bin Birinci Gönüllü Oldu." October 16.

— 2013b. "Dershanelerin Kapatılmasını PKK da İstiyor." November 19.

— 2014. "Hocaefendi: Bir Kişi Duymadım ki Çıksın Bu Okullar Zararlıdır Desin.” March 20. 


\section{Appendix: Data and Methods}

I utilized a multi-method approach in this study. My data comes from a variety of sources including interviews, field observations, social movement publications, archival materials, and secondary sources.

\section{Interviews}

In the summers of 2009 and 2011, I visited civil society establishments of the three major social movements (namely the Kurdish ethno-nationalist movement, the Gülen movement, and Hizbullah) in Diyarbakır, the central city for Kurdish resistance movements. These social movement organizations included charity organizations, solidarity associations, reading centers for youths, neighborhood fraternity unions, and women's clubs.

I conducted 77 field interviews, most of which were fully recorded. I identified recurring themes and selectively transcribed and translated the relevant portions into English. Instead of transcribing word by word, scholars find this selective transcription approach useful in dealing with large interview data. ${ }^{1}$ Interviews were designed as semi-structured, faceto-face, and informal in order to establish non-hierarchical relations with the respondents. ${ }^{2}$ Interviewees include active politicians in the pro-Kurdish party (DTP) and the pro-Islamic party (AKP), Kurdish ethno-nationalist and Islamic activists, and non-affiliated local Kurds including some journalists, writers, religious leaders, and artists.

Since the Kurdish issue remains a touchy subject in Turkish politics, I alter any identifying characteristics throughout the study in order to maintain confidentiality. Although some interviews were held in the city of Urfa, most of the interviews were conducted in Diyarbakır. The majority of the politicians were serving as deputies in the Turkish Parliament and interviews with them were conducted in the Turkish Grand National Assembly as well as at pro-Kurdish party headquarters in Ankara.

\section{Field Observations}

My field observations and informal conversations with activists were particularly useful in illuminating the nature of competition among the rival movements. At several occasions during my interviews, I had some other interested individuals who listened to the entire interview conversation,

1 Heaton 2004: 66.

2 Taylor 1998. 
and later, engaged in dialogue with me. At times, I recorded some occasional gatherings and informal group discussions in which three or four activists answered my queries freely. When the activists did not allow me to record, however, I took written notes. I jotted down informal communications in the field as I shadowed their gatherings, so I could grasp the "hidden transcripts" of the rival movements, i.e. criticisms of the "other" that go on behind the scenes. ${ }^{3}$

These informal interactions taught me to realize how important it is to build trust in the field. I was especially fortunate to get support from two leading KCK activists in Diyarbakır, Mr. X and Mr. Y, who served in prison for their cause. In my visit to various ethno-nationalist organizations, either Mr. X or Mr. Y escorted me and made sure that the interviewees allowed me to record. Although they are not among my respondents, I spent considerable time with Mr. X and Mr. Y and engaged in many informal discussions, which provided me valuable information.

I was also in the field when Gezi protests erupted in summer 2013 as well as before, during, and after the general elections in June 2011 and June 2015. The election time periods were especially useful to observe the dynamics of competition in the field. As a participant observer, I took hundreds of photographs and made quite a number of video clips of communal events such as political rallies of pro-Kurdish and pro-Islamic parties as well as dengbej (traditional Kurdish male singers) performances, Friday prayer protests, and rituals in Kurdish funeral homes. I utilized these documents to inform my analyses on activists' symbolic contestations.

\section{Analysis of Movement Publications}

In addition to the field data, I collected and examined a wide range of movement publications of all three social movements including press releases, public statements, annual reports of movement organizations, periodicals, flyers/brochures, and documents in movement-controlled websites. Some issues from the dailies of the Gülen movement and the Kurdish ethno-nationalist movement, respectively Zaman and Gündem, are utilized for further information about the movements' activism in the region. Moreover, I have collected the prison notes of the PKK leader, Abdullah Öcalan. Öcalan's messages to the outside public are regularly recorded by his lawyers in their monthly meetings since 2007. I gathered these notes, which make up almost a thousand pages, from the PKK affiliated websites such as http://www.rojaciwan.com/ and http://www.firatnews.com/. 
Hizbullah's weekly periodical, Doğru Haber, its quarterly magazine Banga Heq Ji Kelhaamed, and the website of its news agency, Ilke Haber Ajansı, were particularly helpful since I was able to conduct few interviews compared with other movements due to their reluctant attitude toward outsiders. Continued police surveillance is the primary reason for the Hizbullah activists' unwillingness to talk to strangers. Many activists have either served some time in prison or had been arrested in the late $1990 \mathrm{~s}$ on terrorism charges, and members of official associations today still are faced with the legacy of Hizbullah's illegal operations. For instance, only a month after denying my request for an interview, an Istanbul representative of Mustazaf-Der (Hizbullah's official charity organization) was arrested. In need of additional sources on the movement, I obtained the court defense of Hizbullah's military flank leader, Cemal Tutar, wherein he narrates the history of the movement from an insider perspective. I also examined the Hizbullah activists' memoirs, which were published as novels to avoid legal barriers. I agree with Andrew Martin's claim that social movement publications are an "underutilized resource" in current research, and scholars need to benefit from these significant sources of information. ${ }^{4}$

\section{Secondary Sources}

I have also collected many secondary sources on Turkey's Kurdish question. These include data from Turkish Statistical Institute archives, data collected by the Directorate of Associations in Diyarbakır, public surveys, journalist accounts in the Turkish press, and non-academic books published in Turkish. 



\section{Index}

Abdil, Songul 156

Adana 93, 96-97, 109

Alevi 40, 87, 124, 126

Ankara 34, 37, 110, 121, 123

Anter, Musa 155

assimilation 42, 117-118

Atatürk, Kemal Mustafa

and Abdullah Öcalan 52, 98

founding of the Turkish Republic 31-32, 121

political strategy $33,94,104,123,168$

autonomy 14, 39, 148, 174

Bağlar 87, 91

Basque Homeland and Freedom see Euskadi Ta Askatasuna (ETA)

Basque separatism 14

Batman 37-38, 41, 61-62, 86, 137

Baydemir, Osman 59, 86, 92, 135, 155

Beşikçi, İsmail 54

Bingöl 38, 61-62, 93

Bitlis $38,61-62$

Bourdieu, Pierre 50, 72-73, 109, 162-163, 173

Çelik, Feridun 59

census 31,82

charity

and political clientelism 22, 29, 80-81

as reputation work 29,81

associations 83

volunteers $71,84-85$

Cizre 91

coercion 22

Constitutional Court 34, 131

contentious politics 19-21, 25, 135

coups $32-33,43-44,57,63,71,151$

cultural framing 16

Cumhuriyet 116, 177

Daesh 38-39, 47, 99, 164, 177

Demirbaş, Abdullah 131

Demirtaş, Selahattin 46, 133, 174

Democratic Patriots' Party (PWD) 54, 177

Democratic People's Party (DEHAP) 34, 59-6o, 62,177

Democratic Regions' Party (DBP) 34, 38, 177

Democratic Society Party (DTP) 34, 53, 60, 62, $109,122,131,135,149-150,155^{-157}, 177$

democratization 22, 45, 6o, 65, 135-136

Dersim 96-156

discourse

and ideology $43,52-54,93,111-114,126-128$, $131,15^{2}$

Islamist 6o, 115

Marxist 54, 93, 110, 114, 117

strategic 42, 59, 100-101, 140, 165
DİAYDER (Religious Leaders' Assistance and Solidarity Association) 109-110, 116-120, 145, 177

Diyarbakır

city of $10,22,32,34-37,40,58,70-71,82-83$, $85,91,100,102-104,106,109,118-119,135$, $137,142,145,163,199$

mayor $59-62,86,92,126,131,155$

municipalities 87, 92-93, 99, 135

prison $18,33,200$

dynamic mobilization model 19-22

education/reading center 28, 63, 69, 199

Elçi, Şerafettin 128

elections $34,36,38,43-46,54,59,60-62,64$,

$83-84,86,91-92,116,118,120,134,145,15^{2}$,

$155,174,200$

electoral activism 18, 22, 67, 122, 135, 163

electoral system 163

Emergency Rule Law (OHAL) 37, 57-58, 63, 71, 148

Erdoğan, Recep Tayyip 43, 45-47, 101, 120, 131, $134,163,174$

ethnic identity $15-16,43,76$

ethnicity 12, 14-16, 75, 173

ethnopolitical movements 17

European Parliament 95

European Union

resources and support for Kurdish activities 83,95

Turkey's application for membership 26, 29, $42,50,55-56,60,71$

Euskadi Ta Askatasuna (ETA) 145, 165, 177

fairs and festivals see Newroz (New Year)

federalism 174

Felicity Party (SP) 45, 177

flag see symbolic resources

formal political structures 164

frames and framing perspective $74,77,101,111$

Free Cause Party (HÜDA-PAR) 10, 38, 47, 64,

$142-143,177$

\section{Geertz, Clifford 110}

Gendarmerie Intelligence and Anti-Terror Struggle (JITEM) 10, 101, 148-149, 153-154, 177

Germany 167

guerrilla war 18, 33

Gülen, Fethullah 39, 42, 46-47, 62, 90, 109-110, $120-121,123,136-137,152,161$

Gülen movement see Hizmet

Hakkari 58, 61-62, 91, 109

Helsinki summit 55 
Hizbullah 9, 27, 33, 36-38, 63-64, 73, 105, 122, $126,150,153^{-154}, 15^{8-159,} 166$ and $\operatorname{Iran} 36,38,63,143$ associations 10, 29-30, 38, 63-64, 75, 79-81, 83, 88-89, 93, 101-103, 131, 138-140, $142-143,161,163,201$

fight against the PKK 10, 21, 37-38, 47, 53-54, $64,89,139,146,158,160,163,165$

Kurdish culture $16,18,22-23,30,37-38,76$, $98,107,139-140,142$

public celebrations $28,88,101-105$

Hizmet

as social movement $29,33,39-40,42,46-47$, 61-62, 74-76, 81, 84-86, 91-92, 94, 102, 119, $121,123,136,140-142,151,154$ associations 39-40, 42, 63, 79, 83-86, 89-90, $93,95,98,103,131,15^{2}$

Kurdish volunteers of $16,40,42-43,85,98$, $123,161-162$

prep-centers 39-42, 63, 89-9o

schools 39-40, 42-43, 63, 85, 90-91, 136-137

human rights $15,47,59,135^{-136}$, 139, 146, 148, 168

Human Rights Association (İHD) 34, 69, 146 hunger strikes 49

identity

as reaction to repression $17-18,32,36,116$, 118,139

competing identities $16,30,42-43,76,87,94$, $102,110,117,120,122-124,132,142,167$

modernization $32,52-53,58,139$

united or divided $143,15^{2}$

Iran $31,49,54,63,126$

Iranian Revolution 36, 128, 143

Iraq 9, 31, 42, 54, 59

Syrian Civil War 47

War (of 2003) 29, 58-59

Iraqi Kurds 36, 47, 59

Irish Republican Army 13, 18, 167

Islam

and Kurds 9-10, 14, 16-18, 22-24, 30, 33, 36-38, $47,61,68,73-76,78,81,84-89,93,97-98$, 102-107, 109-110, 113-129, 131-133, 138-143, $152,155,157-163,166,168,174$

Islamic parties 54, 6o, 109, 131, 199-200

Islamic State (ISIL) see Daesh

Israel 63, 102, 160-161

Istanbul 37, 40, 42, 49, 84, 116, 147, 152, 163, 201

Izmir 42, 109

Justice and Development Party (AKP) authoritarianism 46 corruption 61-62, 64 criticism of $62,86-87,119,150,155^{-157}$ democratization $45,60,63,136$ electoral success $50,60-61,63,86,114-115$ Ergenekon investigation 30, 149-150, 156-157, 161
European Union membership 45, 60

Kurdish policy 42, 44-45, 50, 52, 6o, 63, $65-67,87-88,120,131,135,168$

political Islam $43,52,54,60,87$

relationship with Gülen movement 42,46 , $61-62,64,75^{-7} 6,86,136$

relations with Kurdistan Workers' Party

(PKK) 45-47, 63-64, 115, 120, 163 see also cease fires

rise of $29,45,52,60$

roots of 44

Syrian Civil War 47

Kemalism 52,123

Khomeini, Ayatollah Ruhollah 38, 139

Kongra-Gel 9, 17, 59

Kurdish culture 18, 38, 42, 61, 113-114, 118, 138

Kurdish Freedom and Democracy Congress (KADEK) 58, 177

Kurdish languages 10, 30, 42, 56, 58, 69, 92, 107, $131-138,167,192$

Kurdish leftist movements 9, 54, 81, 94, 98, 101, $113,115,167$

Kurdish movement $23,31,36,52,59,63,96,99$, 162

Kurdish Regional Government (KRG) 42, 59, 177

Kurdish religions $87,106,114,117-118$

Kurdistan 42, 51, 54-55, 93, 98, 116, 122, 126, 137 , $139,149,167$

acknowledgement of 42

Iraqi Kurdistan 43, 50, 136-137, 174

Kurdistan Democratic Party (KDP) 96

Kurdistan Freedom Falcons (TAK) 168

Kurdistan National Congress (KCK) 10, 45, 82, 92, 177, 200

Kurdistan Workers' Party (PKK) 33, 65, 90, 100-101, 120, 147-148, 152-154, 156, 157-16o, 162-168, 174-175, 177

allies 39

attacks on/by Turkish Armed Forces 65-66, 101

attempts to shed terrorist label $9,17-18,36$, $38,42,51,54,58-59,100$

cease-fires 10, 45-47, 50, 63-65

elimination of competitor opposition 10,38 , $47,63-64,89$

foreign support 47

forging national identity 18-19, 30

founding of 33,63

garnering local support 10, 17-18, 33, 35, 45, $5^{2}, 81,89,90-91,115$

guerrilla attacks $10,33-35,37,46-47,54-55$, $60,63,65,81-82,117,145,148$

ideological motivation $16,34-35,47,51-54$, $59,65,93-94,106-107,113-115,118,122-127$, 131-134, 138, 140, 142, 145, 155

Kurdish politics $10,54,131$ 
Marxism 52, 93

moderates demands 10, $16,34,45-46,59-60$, $62,64,91,101$

PKK parallel government 10, 34, $5^{8}$

terrorism 49, 58, 65-67, 82, 91

women 30, 93-99

Kurmanji 135, 139

legal prosecution of Kurdish activists 45, 135

literacy 82

local government see municipalities

Mardin 37, 40, 61, 62

martial law 10, 27, 57, 63, 69, 71, 101, 105, 145, 148,162

Marxism 33, 37, 52, 54, 93, 102, 110-111, 113-114, $116-117,121,127,170$

mayors, pro-Kurdish $38,59,86,92,131-132,135$, $155^{-15} 6$

media 10, 34, 39, 72, 90, 94, 99, 102, 115, 120, 132, $138,140,161,171$

MED-TV 49, 131

Mersin 93, 109

migration 81-82, 109

modernist movement 105

Movement for Kurdish Language and Education (TZP) 133-134, 177

multi-institutional politics approach/perspective $11-13,16,28,170,173$

municipalities $18,34,36,55,83,86-87,92-93,95$, $98-99,105,116,131,134-135,162$

murders of Kurdish activists 37, 146, 149, 155

names, Kurdish 56, 135

narratives 30, 34, 74-75, 129, 143, 145-147, $149-150,152,154-155,161-162,167,158$

National Salvation Party (MSP) 44, 177

National Security Council 57

nationalism 14, 16, 32-34, 36-37, 43, 59, 73, 114, $126,154,168$

Newroz (New Year) 18, 46, 58, 64, 101, 122, 125

nongovernmental organizations, 11, 92

non-violence $10,20,23,34,38-39,52,55,59-60$, $121,140,161-162,164-165,169-170$

notables 35

Nursi, Said 3o, 39, 63, 120-125, 129, 137, 139-142

Nusaybin 42

Öcalan, Abdullah

democratic Republic thesis $9,17,51-52,54$, 174

leadership 29, 34, 37, 49-52, 63, 92-93, 98, $113-115,120,125^{-126}, 157^{-1} 5^{8}$ negotiations with the Turkish state 46 , $5^{1-52}, 54,125,148,154$

Parliament, Turkish 35, 45, 55, 82, 122-123, 131, 143,199

Peace and Democracy Party (BDP) 34, 38, 120, 177
People's Democracy Party (HADEP) 34, 177

People's Labor Party (HEP) 34, 177

People's Protection Units (YPG) 39, 177

Perwer, Şivan 167-168

places, naming and re-naming of 42, 135

political opportunity structures 13,20

political parties 10, 13, 34, 38, 54-55, 61, 64, 80,

$83,86,135,143,151,164,171$

political process theory $20-21$

population 18, 31-32, 40, 80, 82, 89, 94, 105-106, $110,123,126,129,149,153$

pro-Kurdish parties

closure by the Constitutional Court 13, 34, 13

electoral success $18,36,54,62,83-84,95$

legal prosecution 131,135

municipalities $36,55,84,86-87,92$

Prophet's birthday 102, 104, 115, 138, 143

protest and protest events $13,22-23,26,30$, 47, 49, 63-64, 72-74, 90, 95, 97, 100-102, 119, $133-134,138,168,170,200$

Radikal 86, 115, 120, 126, 135, 138, 148, 156, 167

reading salon 90-93

repertoires of contention 113

repression 12-14, 17, 164, 169

Republican People's Party (CHP) 168, 177

resistance $13,18,35,86,97,112,121,156-157,160$, 199

resource mobilization theories 16

resources

and Kurdish identity 18, 74

legitimacy 10

mobilization of $16,18,55,72,75$

symbolic 10, 18, 24, 28, 73, 75

ROJ-TV 34, 120, 131-132

social movements

and culture $10,14-15,28,58,111,171$

competition 10, 17, 21, 23-27, 29, 50, 63 , 68-69, 71-76, 78-80, 94, 106, 110, 146, 150, 162,171

reputation work 10, 21, 28-29, 80-81, 110 strategy 11-12, 15-17, 28, 103, 106, 111, 150, 171 theories of 12, 14-17, 20-21, 26

secularism 32, 39, 43-45, 52-53, 6o, 93-94, $104-105,114,121,123,131,138,141,159,161$ 168,174

self-determination $54,75,170,174$

semi-democratic regimes 170

Sheikh Said 104-105, 118, 125-126, 139, 169

Siirt 6o-62

Şırnak 58, 109, 136

socialism $35,54,73,93,113,163$

southeast (as region of Turkey) 16, 18, 24, 27, 29, $31,33,36,40,42,50,53,58,71,74,76,79-81$, $84-86,93,110,114,121,136,149,152,161$

spaces $30,36,58,71,75$

state policies $12-13,15,17,152,169$ 
state security courts 57,151

state-society relations 167

Sur Municipality 105, 135

surveys 50,82

Susurluk accident 147

Tanrıkulu, Sezgin 168

terrorism 13, 32, 37, 49-50, 58, 101, 148, 165, 201

Tilly, Charles 12, 19, 22, 24, 113, 172

torture 10, 33, 146, 148-149, 153, 159, 169

transnational activism 6o, 168, 170

tribal identities 18, 32, 35, 93, 124, 145-146, 207

tribes, Kurdish 18, 35, 145-146

TRT Şeş 57, 131-133, 138

Tunceli $58,61-62,156$

Türk, Ahmet 86, 149, 155-156

Turkish Armed Forces see Turkish military

Turkish Constitution 13, 34, 36, 42, 55-56,

135-136

Turkish leftist movements 34,138
Turkish military 10, 30, 32-33, 37, 43-45, 49,

51-53, 55, 6o, 66-67, 71, 82, 96, 98-99, 101, 123, $145-148,151,153,156-157,161$

Türkiyelileşme 17

United States 47, 62, 98, 152, 157

unknown-assailant murders 155

Urfa 40, 44, 115, 135, 157, 199

Van 6o, 98, 109, 135

village guard system $82,145^{-147}$

Virtue Party (FP) 44, 177

Welfare Party (RP) 44, 177

women $28,30,34,42,58,63,69,75,79,82$, 93-101, 106, 115, 156, 199

Yenişehir 91, 99

Zaman 39, 42, 200

Zana, Leyla 98, 131

Zazaki 139, 135 